\title{
Purificación y caracterización de poligalacturonasas de Aspergillus kawachit
}

\section{Juan Carlos Contreras Esquivel}

versidad Nacional de La Pla Facultad de Ciencias Exactas

Mayo 2003, Argentina

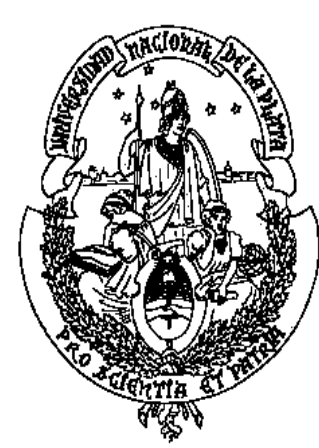




\section{Purificación y caracterización de poligalacturonasas de Aspergillus kawachii}


Director de tesis: Profesor Dr. Claudio E. Voget CINDEFI

Facultad de Ciencias Exactas, UNLP, Argentina 


\section{Purificación y caracterización de poligalacturonasas de Aspergillus kawachii}


Juan Carlos Contreras-Esquivel

Purificación y caracterización de poligalacturonasas de Aspergillus kawachi Tesis doctoral - Mayo, 2003

Facultad de Ciencias Exactas, Universidad Nacional de La Plata, Argentina 


\section{Contenido}

Reconocimnentos, agradecimiento y dedicáninas

Reconocimientos, agradecimiento y dedicatoria............................................... I

Contenido.

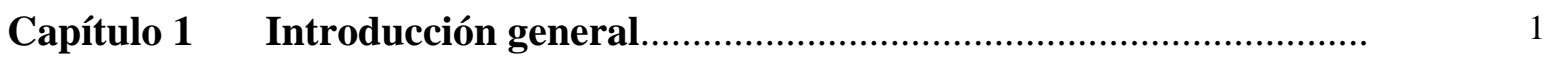

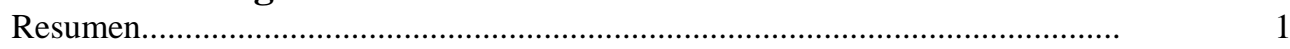

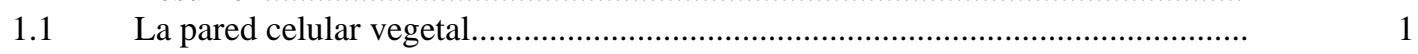

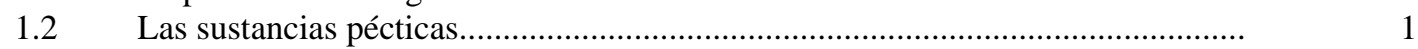

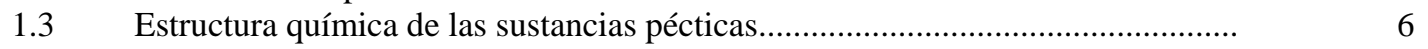

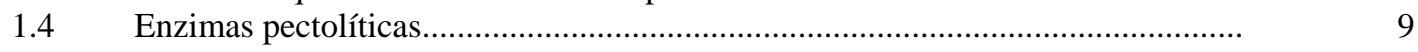

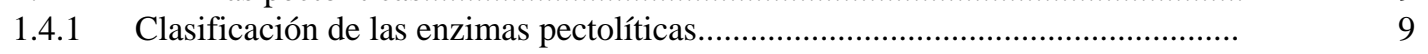

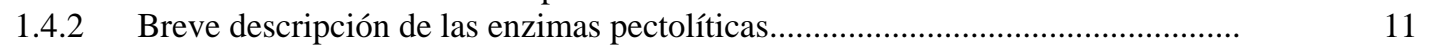

1.4.3 Aplicaciones de las enzimas pectolíticas......................................................... 13

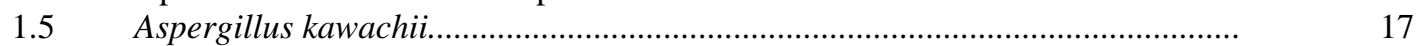

1.5.1 Enzimas de Aspergillus kawachii................................................................... 18

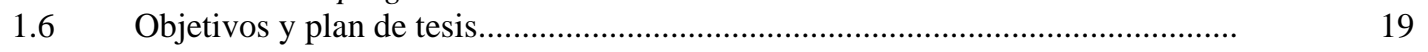

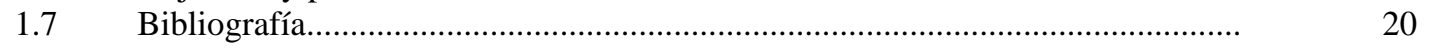

$\begin{array}{lll}\text { Capítulo } 2 & \text { Caracterización del sistema pectolítico de Aspergillus kawachii } 27\end{array}$

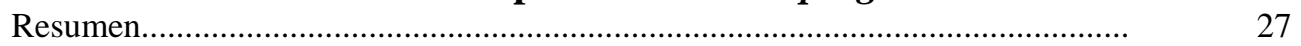

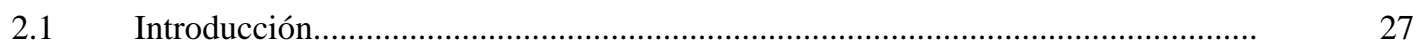

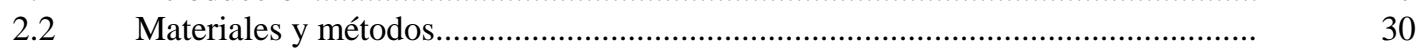

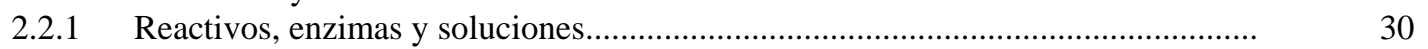

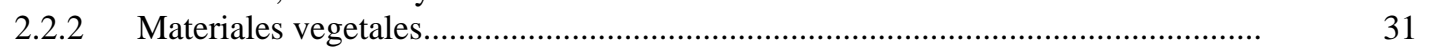

2.2.3 Microorganismo, medio y condiciones de cultivo............................................... 33

2.2.4 Procesamiento de los cultivos y obtención de muestras para el screening de

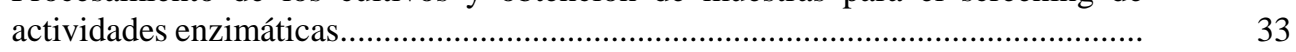

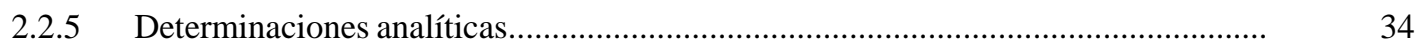

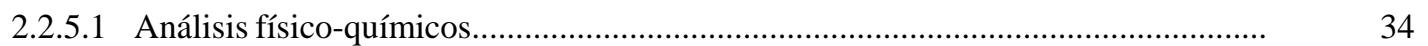

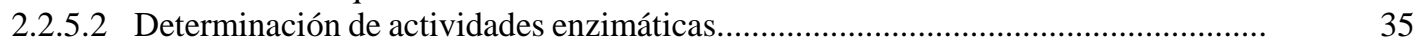

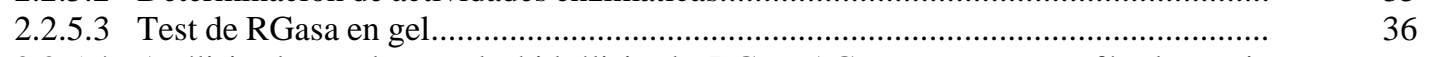

2.2.5.4 Análisis de productos de hidrólisis de RG y AG por cromatografía de tamiz

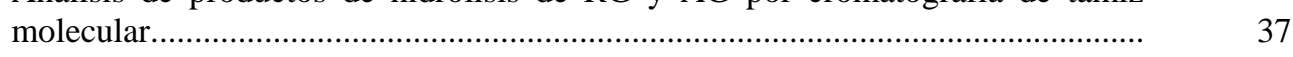

2.2.5.5 Adsorción de enzimas en membranas de fibra de vidrio...................................... 37

2.2.5.6 Ensayos de estabilidad térmica....................................................................... 37

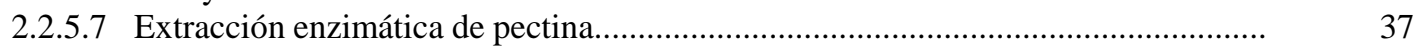

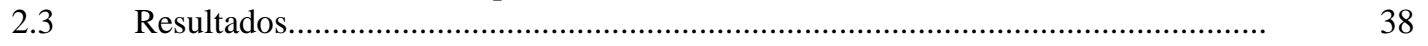

2.3.1 Crecimiento de A. kawachii en medios con glucosa y pomaza de limón................. 38

2.3.2 Screening de la actividades enzimáticas.......................................................... 41

2.3.3 Adsorción de enzimas en membranas de fibra de vidrio........................................ 48

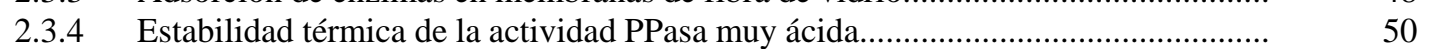

2.3.5 Extracción enzimática de pectina de limón.......................................................... 50

2.4. Discusión........................................................................................... 52

2.5 Bibliografía..............................................................................................

\section{Capítulo 3 Purificación y caracterización parcial de una poligalacturonasa} ácida de Aspergillus kawachii

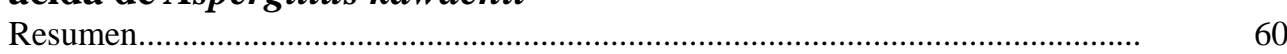

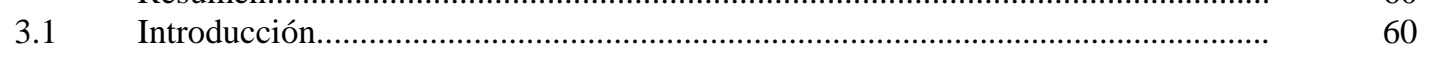

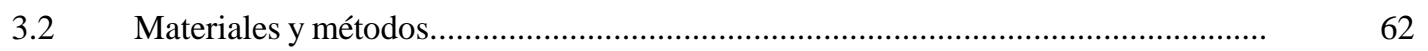

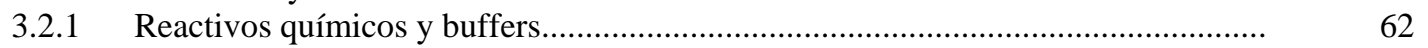




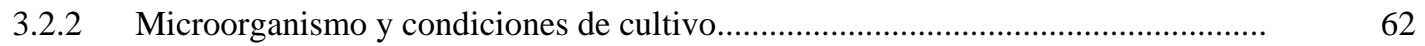

3.2.3 Purificación de la poligalacturonasa ácida. 63

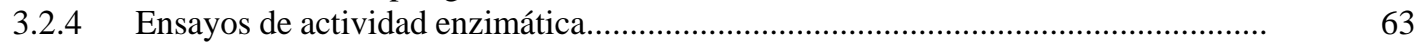

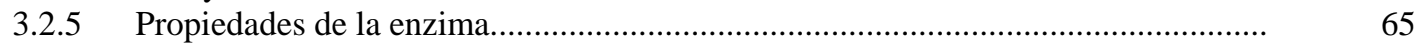

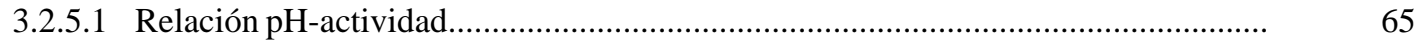

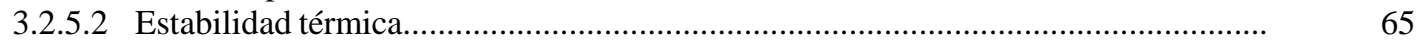

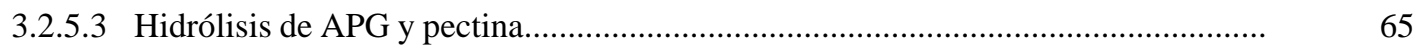

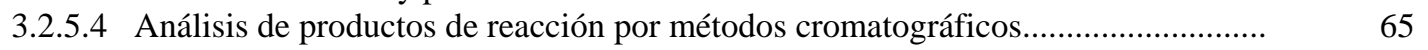

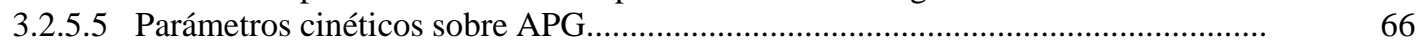

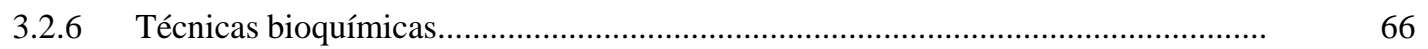

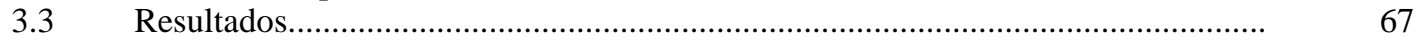

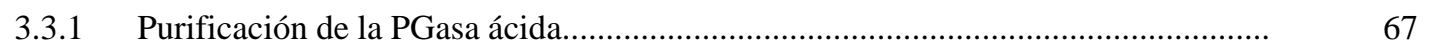

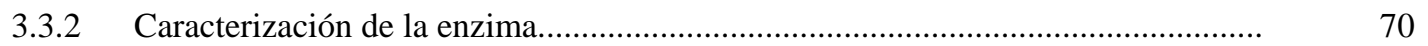

3.3.3 Propiedades de la enzima................................................................................ 72

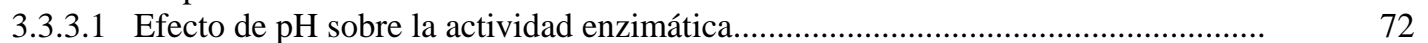

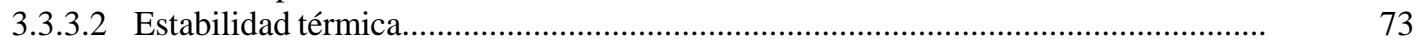

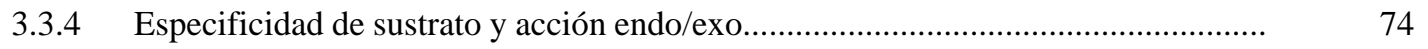

3.3.5 Parámetros cinéticos sobre APG..................................................................... 76

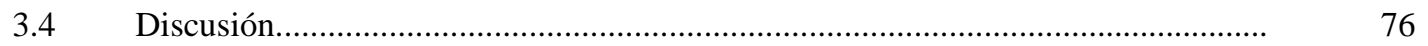

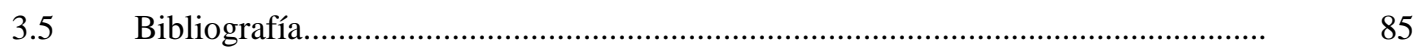

Capítulo 4 Extracción enzimática de pectina y maceración de tejidos vegetales con poligalacturonasa ácida de Aspergillus kawachii....

Resumen.

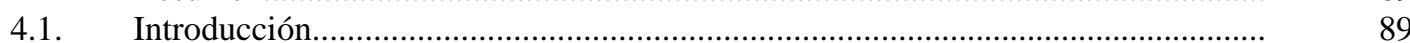

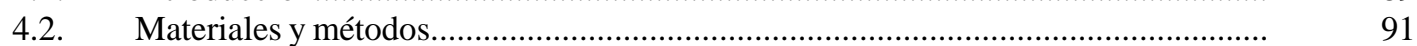

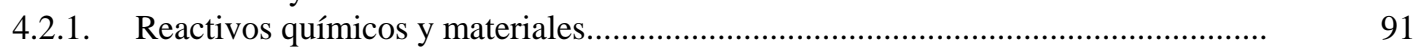

4.2.2. Preparación y análisis de protopectinas de albedo de limón................................. 92

4.2.3. Degradación enzimática de protopectinas......................................................... 96

4.2.4. Extracción de pectina a partir de protopectina de albedo de limón con PGI............ 96

4.2.5. Extracción de pectina a partir de pomaza de limón con PGI................................... 96

4.2.6. Extracción de pectina a partir de pomaza de cáscara de limón con endo-PG de $A$.

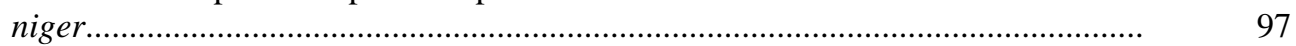

4.2.7. Extracción química de pectina a partir de pomaza de limón................................. 97

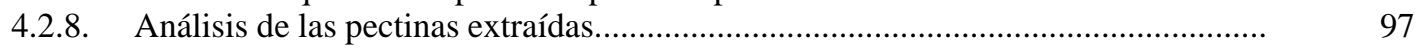

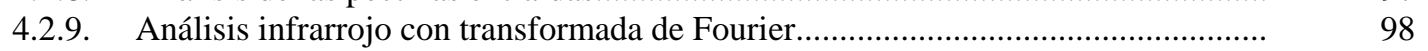

4.2.10. Maceración de tejidos vegetales......................................................................... 98

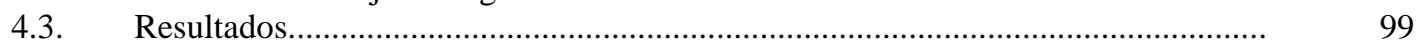

4.3.1. Caracterización fisico-química de las protopectinas.............................................. 99

4.3.2. Estabilidad química de las protopectinas............................................................ 103

4.3.3. Acción de PGI sobre protopectinas.................................................................. 105

4.3.4. Extracción de pectina a partir de protopectina de albedo de limón con PGI de $A$.

4.3.5. Extracción química y enzimática de pectina de pomaza de limón............................ 108

4.4. Maceración de tejidos vegetales con concentrados enzimáticos y PGI de A. kawachii........................................................................................................ 115

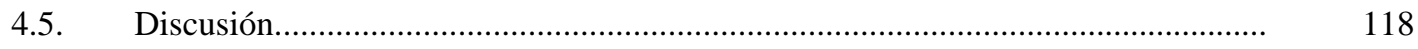

4.6 Bibliografía............................................................................................ 123

\section{Capítulo 5 Adsorción de poligalacturonasas de Aspergillus kawachii sobre} membranas de fibra de vidrio.................................................... 127

Resumen...................................................................................................... 127

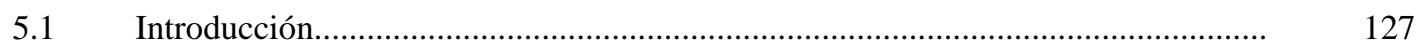

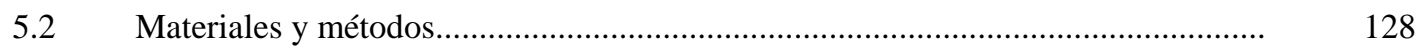

5.2.1 Reactivos y soluciones buffer..................................................................... 128 
5.2.2 Microorganismo y medio de cultivo............................................................................ 130

5.2.3 Proceso de filtración........................................................................................ 130

5.2.4 Ensayos de actividad enzimática.................................................................... 130

5.2.5 Propiedades de las enzimas...................................................................................... 131

5.2.5.1 Relación pH-actividad.......................................................................................... 131

5.2.5.2 Estabilidad térmica................................................................................................... 131

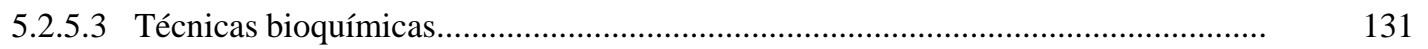

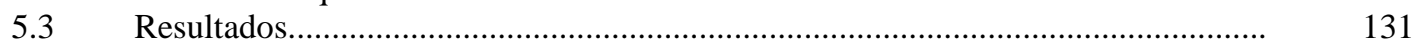

5.3.1 Adsorción de enzimas extracelulares de A. kawachii a filtros a medios de filtración............................................................................................................. 131

5.3.2 Efecto del pH sobre la adsorción de las PGasas de A. kawachii y otras PGasa

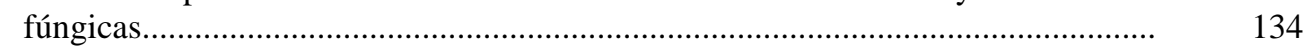

5.3.2 Desorción de la actividad PGasa....................................................................... 135

5.3.3 Efecto de la composición del medio en la adsorción................................................. 137

5.3.4 Isotermas de equilibrio para la actividad PGasa.......................................................... 138

5.3.5 Recuperación de la actividad PGasa adsorbida......................................................... 140

5.3.6 Purificación de las PGasas...................................................................................... 140

5.3.7 Caracterización bioquímica de las PGasas............................................................ 144

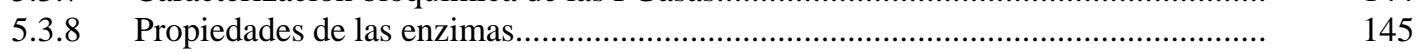

5.3.8.1 Efecto del pH sobre la actividad enzimática.............................................................. 145

5.3.8.2 Estabilidad térmica....................................................................................... 146

5.3.8.2 Especificidad de sustrato y acción endo/exo........................................................... 146

5.3 Discusión........................................................................................................... 147

5.4 Bibliografía....................................................................................................... 151

Capítulo 6 Discusiones generales...................................................................

$\begin{array}{ll}\text { Abstract } & 156\end{array}$ 


\section{Indice de figuras}

1.1

4.1.

4.2.
Microfotografía de dos células vegetales contiguas.

2

Modelo de inserción de polisacáridos de pared celular primaria tipo I correspondiente a plantas fanerógamas.

Polímeros estructurales de pectina.

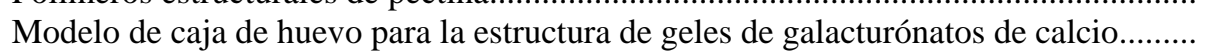
Degradación de fragmentos de sustancias pécticas por enzimas pectolíticas específicas.

Evolución de cultivo de A. kawachii en medios con glucosa y cáscara de limón (PL) Actividad glicosidasa producida por A. kawachii en distintos medios complejos en comparación con un producto enzimático comercial.

Cromatografía de tamiz molecular de RG.

Test de placa y SDS-PAGE para detectar actividad RGasa......

Curvas de actividad/pH para PGasa y PPasa antes (MC) y después (Pe) de filtrar por membranas de fibra de vidrio.

Estabilidad térmica de la actividad PPasa muy ácida.

Extracción enzimática de pectina con $A$. kawachii.

Esquema de la purificación de la PGasa ácida de A. kawachii IFO 4308.

Perfil de elución de la PGasa ácida de A. kawachii en la cormatografía de intercambio aniónico (Separose Q)...

SDS-PAGE e IEF de la PGasa ácida de A. kawachii.

Cromaografia de fase reversa de la PGasa ácida (PGI) de A. kawachii.

Efecto del pH en la actividad de PGI.

Efecto del pH y la presencia de albúmina en la estabilidad térmica de PGasas.

Hidrólisis de APG y pectina cítrica por PGasas.

TLC de los productos de hidrólisis de APG.

Isotermas de adsorción de agua de protopectinas (A) y de adsorción-desorción (B) de pomaza de limón a $20^{\circ} \mathrm{C}$.

Relación de grado de metoxilacion (GM) vs capacidad de hinchamiento (CH) de protopectinas de limón.

Efecto de la temperatura y pH sobre la liberación de AGA de protopectinas de limón (M1, M2, M3, y M4). Incubación 60 minutos.

Perfil pH/actividad de PGI para diferentes protopectinas...

Extracción de pectina de protopectina con PGI.

Cromatografía de tamiz molecular (HPLC) de extractos químicos y enzimáticos (PGI) de pomaza de limón.

Cromatografía de intercambio aniónico (HPLC) de extractos químico y enzimático (PGI) de pomaza de limón.

FTIR de muestras de pectina extraída químicamente, en presencia de PGI y el blanco de extracción en las condiciones de extracción enzimática.

Cromatografía de tamiz molecular (HPLC) de extractos químico y enzimático de pomaza de limón

Cromatografía de intercambio aniónico (HPLC) de extractos químico y enzimático de pomaza de limón.
4

6

8

14

39

44

46

48

49

51

51

64

69

71

72

73

74

77

79

101

103

104

105

107

109

110 
4.11 Cromatografía de intercambio iónico a nivel preparativo de pectina de extraída enimáticamente y químicamente.

4.12 Maceración de tejido de zanahoria con concentrados de los medios glucosa y pomaza de limón a pH 2.0 y 5.0 .

Maceración de tejido de zanahoria y pimiento por PGI de A. kawachii........................

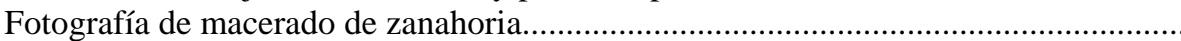

Meceración del de frutilla por PGI de A. kawachii......

SDS-PAGE de poligalacturonasas de G. klebanii y A. niger.... 


\section{Indice de tablas}

1.1

1.2

4.1.

4.3.

4.4 .

4.5.

4.6.

4.7.

Componentes estructurales de los polisacáridos de la pared celular vegetal.

3

Clasificación de las sustancias pécticas de acuerdo a diferentes criterios........................ Clasificación de enzimas pécticas de acuerdo a los lineamientos de Comisión de Enzimas y asignación de familia de hidrolasas.

Aplicación tecnológica de enzimas pectolíticas.

Empleo de A. kawachii como iniciador de fermentación en la elaboración de alimentos fermentados en China, Corea y Japón...

Propiedades de algunas enzimas purificadas de Aspergillus kawachii.......

Enzimas clonadas de A. kawachii y su expresión en diferentes cepas de Saccharomyces cerevisiae...

Composición química de diversos materiales vegetales.

Parámetros de los cultivos de A. kawachii en medios con materiales vegetales y glucosa.

Actividades enzimáticas producidas por A. kawachii en distintos medios de cultivo

Composición de RG de soja y de manzana (moles \%)..

Hidrólisis de RG y AG evaluada por medidas de poder reductor.

Actividades de las muestras empleadas en el test de placa para detectar actividad RG

Propiedades físco-químicas de algunas poligalacturonasas de Aspergillus spp............. Resumen de purificación de la PGasa ácida de A. kawachii

Tabla se comparación de secuencia de aminoácidos de A. kawachii con otras especies de Aspergillus. soluciones saturadas

\section{soluciones saturadas.................}

Liberación de AGA por autoclavado de protopectina...................................................... 105

Degradación enzimática de protopectinas por PGI........................................................... 106

Condiciones de extracción, productividad, y rendimientos de pectinas extraídas enzimática y químicamente de pomaza de limón.

108

Composición de azúcares de extractos químicos y enzimáticos de pomaza de limón.

Actividades enzimáticas y concentración de proteína determinados antes y después de la filtración de cultivos de A. kawachii por diferentes filtros y membranas a $\mathrm{pH}$ 3.0.... Adsorción y desorción de la actividad PGasa de A. kawachii a filtros de fibra de vidrio...

Efecto de la composición del medio en la adsorción de la PGasa de G. klebanii a filtros de fibra de vidrio.. 


\section{Reconocimientos:}

El autor quiere reconocer el apoyo recibido por las siguientes instituciones:

Al Centro de Investigación y Desarrollo en Fermentaciones Industriales (CINDEFI), Facultad de Ciencias Exactas, Universidad Nacional de La Plata por darle la oportunidad de realizar sus estudios de investigación en sus instalaciones y laboratorios.

Al Consejo Nacional de Ciencia y Técnica (CONICET), la Agencia de Promoción Científica y Tecnológica (ANPCyT) y la Universidad Nacional de La Plata por el apoyo económico a la investigación. Subsidios: PIP-CONICET 0273 (Res 2851/98). 1999-2001. ANPCyT (Código 14-07288). 2000-2003 y programa de incentivos de la Universidad.

Agencia Española de Cooperación internacional (Beca MUTIS, año: 1997-1999)

Universidad Autónoma de Coahuila. Saltillo, Coahuila, México (Beca complementaria, año: 1997-2001).

Fundación de la Facultad de Ciencias Exactas, Universidad Nacional de La Plata (Beca complementaria, año: 2000)

Red Latinoamericana de Biotecnología (Beca complementaria, agosto 2000)

\section{Agradecimiento:}

A todos mis compañeros y amigos del Centro de Investigación y Desarrollo en Fermentaciones Industriales (CINDEFI), Facultad de Ciencias Exactas, Universidad Nacional de La Plata. Quiero agradecer al Dr. RoqueA. Hours por su apoyo en la gestión de mi solicitud para realizar mis estudios de posgrado en Argentina así como también su apoyo durante este trabajo de investigación. También agradezco a mi director de tesis Dr. Claudio E. Voget por su valiosa asesoría e incondicional amistad. También agradezco a mis compañeros y amigos de laboratorio Carolina Vita, Sebastián Cavalitto, Martha Vallejo, Ramón y Rubén Otolina.

Instituto Nacional de Medicamentos (INAME), Buenos Aires, Argentina.

Se expresa un amplio agradecimiento a la Dra. Catherine Renad y Agnès Gacel de Station de Recherches Cidricoles - Biotransformation des Fruits et Légumes. Institut National de la Recherche Agronomique (INRA), Le Rheu, Francia por las facilidades otorgadas para realizar el análisis de pectinas y azúcares neutros en protopectinas y materiales vegetales.

A la Dra. Bárbara y Dra. Torres CEMICT por su valioso apoyo con los análisis de isotermas. También quiero agradecer a Moon-Sung Chin por su ayuda en la traducción de textos coreanos.

A mis compañeros y amigos del Departamento de Investigación en Alimentos, Facultad de Ciencias Químicas, Universidad Autónoma de Coahuila, Saltillo, Coahuila, México por el apoyo recibido durante este trabajo de tesis. Cristóbal Noé Aguilar, Julio César, Claudia Correa, Sonia 
A mi familia de quienes he recibido su apoyo incondicional en todo momento, muchas gracias.

\section{Dedicatoria:}

Para todos aquellos quienes puedan hacer uso futuro de esta investigación.

\section{Pensamiento:}

"Cada uno de nosotros viene a este mundo a trascender, a dejar huella, aportando su grano de arena para hacer de esta tierra un lugar para ser felices”

V.F. 


\section{Abreviaturas}

\begin{tabular}{|c|c|}
\hline Ara & Arabinosa \\
\hline ACS & American Chemical Society \\
\hline $\mathrm{ADN}$ & Acido desoxirribonucleico \\
\hline AG & Arabinogalactano \\
\hline AGA & Acido galacturónico \\
\hline AMPc & Adenosinmonofosfato \\
\hline APD & Agar papa dextrosa \\
\hline APG & Acido poligalacturónico \\
\hline BCP & Buffer citrato-fosfato \\
\hline CDTA & Cyclohexylene dinitrilotetracetic acid \\
\hline CFR & Cromatografía en fase reversa \\
\hline $\mathrm{CH}$ & Capacidad de hinchamiento \\
\hline CMC & Carboximetilcelulosa \\
\hline $\mathrm{C} / \mathrm{N}$ & Carbono/nitrógeno \\
\hline CreA & Carbon catabolite repressor protein \\
\hline EDTA & Ethylene Diamine Tetra-acetic Acid \\
\hline FPLC & Fast Protein Liquid Chromatorgraphy \\
\hline Fuc & Fucosa \\
\hline FVV & Filtro de fibra de vidrio \\
\hline Gal & Galactosa \\
\hline GM & Grado de esterificación de metoxilos \\
\hline Glu & Glucosa \\
\hline HG & Homogalacturonano \\
\hline KDO & Acido 2-ceto-3-deoxi-D-manano-octulosónico \\
\hline Man & Manosa \\
\hline MVC & Materiales vegetales complejos \\
\hline MHR & Modified hairy regions (región pilosa modificada) \\
\hline MVC & Materiales vegetales complejos \\
\hline ONPG & o-nitro-fenil-glicósido \\
\hline PeL & Pectinliasa \\
\hline PAGE & Polyacrylamide gel electrophoresis/electroforesis en gel de poliacrilamida \\
\hline $\mathrm{Pe}$ & Permeado \\
\hline PL & Pomaza de limón \\
\hline PG & Poligalacturonasa \\
\hline PM & Pomaza de mango \\
\hline PME & Pectinmetilesterasa \\
\hline pnp & p-nitrofenol \\
\hline PPasa & Protopectinasa \\
\hline PR & Pulpa de remolacha \\
\hline PT & Pulpa de tejocote \\
\hline Ram & Ramnosa \\
\hline RG & Ramnogalacturonano \\
\hline RGL & Receptáculo de girasol \\
\hline $\mathrm{RR}$ & Rojo de rutenio \\
\hline SE & Solución stock \\
\hline SDS & Sodium dodecyl sulfate \\
\hline Xil & Xilosa \\
\hline XLNR & Xylanolytic transcriptional activator protein \\
\hline Xyn & Xilanasa \\
\hline
\end{tabular}


CERTHFHCO que el Sr. JUAN CARLOS CONTRRERAS ESQUIVEL (Pasaporte $\mathbb{N}^{\circ} \mathrm{MX}$ 02050044988), el día Dieciséis de Mayo de 2003 ha DEFIENDIDO Y APROBADO su trabajo de tesis titulado "Purificación $y$ Caracterización de Poligalacturonasas de Aspergillus $\mathbb{K}$ Kawachii", realizado bajo la Dirección del Dr. Claudio E. Voguet, alcanzando la calificación de Sobresaliente (10) y cumplimentado las exigencias de la Ordenanza 205 para optar al grado académico de $\mathbb{P O C T O R} \mathbb{D E}$ LA FACULTAD $\mathbb{D E}$ CIENCIAS IXXCTAS.

Se extiende el presente a los Veintiún días del mes de Mayo de 2003.-
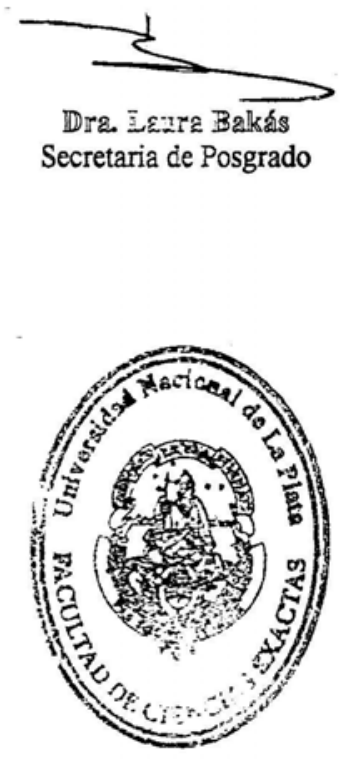


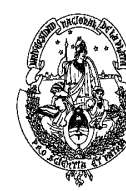

UNLP

Argentina

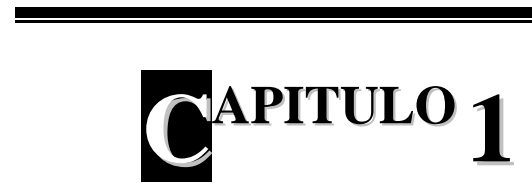

Tesis Doctoral

\section{Introducción general}

Resumen

En este capítulo se realiza una breve descripción de la composición química y la estructura de la pared celular primaria y laminilla media de plantas fanerógamas, en particular de las sustancias pécticas; se detalla la clasificación de las enzimas pectolíticas así como sus sitios y modos de acción sobre la molécula de pectina y sus aplicaciones. Posteriormente se hace referencia a las características fermentativas y producción de polisacaridasas extracelulares de Aspergillus kawachii y su propiedad de producir enzimas ácido-estables. La última parte concierne con los objetivos del trabajo de Tesis.

\subsection{La pared celular vegetal}

La pared celular vegetal es una estructura dinámica que circunda las células, exterior al plasmalema, y cuya composición y propiedades son constantemente adaptadas al crecimiento, diferenciación y variaciones medioambientales. Las paredes celulares de una planta, colectivamente determinan su forma y aseguran la protección contra patógenos. Típicamente, las paredes celulares vegetales están formadas por dos capas: la pared secundaria más interna compuesta básicamente de fibras de celulosa y hemicelulosa y la pared primaria, más externa, formada por las mismas fibras embebidas en sustancias pécticas y algo de proteínas. Las paredes primarias de dos células contiguas se hallan unidas por la laminilla media, estructura formada principalmente por sustancias pécticas, que cumplen así el rol de sustancia cementante (Figura 1.1). Hay diversas revisiones bibliográficas que cubren el estudio físico y químico de las paredes celulares vegetales [Fry, 1986, 1995; Carpita and Gibeaut, 1993; Jarvis and McCann, 2000; Willats et al., 2000].

En la Tabla 1.1 se detalla la composición de los constituyentes polisacarídicos comúnmente encontrados en paredes celulares vegetales. La celulosa, que representa el componente mayoritario, consiste en un polímero lineal de residuos de glucosa unidos por enlaces $\beta$ - $(1 \rightarrow 4)$. La celulosa es una estructura ordenada en forma de fibras y su función principal es conferir rigidez a la pared celular. La hemicelulosa es un polímero más heterogéneo y el segundo en abundancia en los tejidos vegetales. El principal constituyente de 
la hemicelulosa descrito en cereales y maderas duras (hardwoods) es el xilano, que consiste en un esqueleto de residuos de xilosa unidos por enlaces $\beta-(1 \rightarrow 4)$ que pueden estar sustituidos con diferentes azúcares (neutros o ácidos) como L-arabinosa, D-galactosa o ácido Dglucurónico. Estos residuos pueden estar esterificados con grupos acetilo, feruloílo o pcumaroílo. Una segunda estructura de hemicelulosa, descripta tanto en maderas blandas (softwoods) como duras, es el galactoglucomanano compuesto por residuos de glucosa y manosa unidos por enlaces $\beta-(1 \rightarrow 4)$ con residuos laterales de galactosa. La estructura de la pectina, más compleja aún, se describe más adelante.

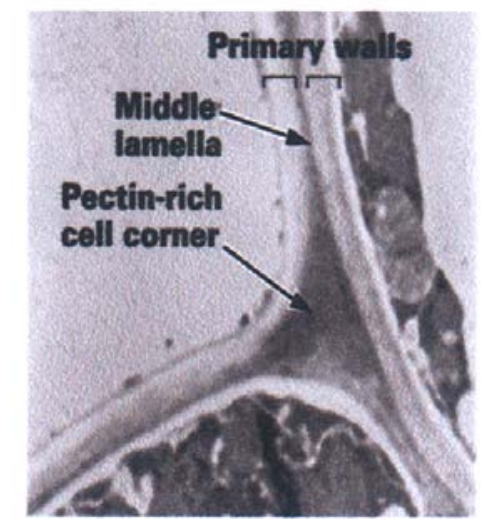

Figura 1.1. Microfotografía de dos células vegetales contiguas. La pared primaria es capaz de expandirse. La lámina media se forma durante la división celular y crece coordinadamente durante la expansión de la célula. En células viejas la pectina ubicada en los rincones suele estar degradada y reemplazada por aire.

En la Figura 1.2 se muestra un esquema del modelo de estructura propuesto para la pared celular primaria típica de fanerógamas, donde se puede observar dos de los tres principales dominios que la constituyen: el entramado celulosa-xiloglucano, que le confiere resistencia a la elongación, y los polisacáridos pécticos (galacturonanos y ramnogalacturonanos) relacionados con la resistencia a la compresión. El tercer dominio formado por proteínas estructurales (como la extensina rica en prolina) y otros componentes vitales (como las enzimas involucradas en el metabolismo de los polisacáridos y la lignina que se incorpora durante la cesación de la elongación y posterior diferenciación) que no se muestran en el modelo. El xiloglucano representa a la hemicelulosa. La síntesis y ensamblado de estos dominios se realiza independientemente uno del otro y los componentes que lo forman pueden variar en respuesta a las necesidades fisiológicas del tejido. Las proporciones relativas de los distintos componentes varían de tejido a tejido. 
Tabla 1.1. Componentes estructurales de los polisacáridos de la pared celular vegetal.

\begin{tabular}{|c|c|c|c|}
\hline Polisacáridos & $\begin{array}{l}\text { Monómeros } \\
\text { mayoritarios }\end{array}$ & $\begin{array}{l}\text { Monómeros } \\
\text { minoritarios }\end{array}$ & Estructura química \\
\hline Celulosa & Glc & & Glc unida por enlaces $\beta(1 \rightarrow 4)$ \\
\hline \multicolumn{4}{|l|}{ Hemicelulosa } \\
\hline Xilanos & Xil & Ara, Gal, & $\begin{array}{l}\text { Xil unida por enlaces } \beta-(1 \rightarrow 4) \text {, sustituciones } \\
\text { de Ara, Gal, GluA. Algunas xilosas y residuos } \\
\text { laterales están acetilados o contienen Afe }\end{array}$ \\
\hline Galactoglucomanano & Man, Glc & Gal & $\begin{array}{l}\text { Man y Glc unidas por enlaces } \beta \text { - }(1 \rightarrow 4) \text { con } \\
\text { sustituciones de Gal }\end{array}$ \\
\hline Xiloglucanos & Glc, Xil & $\begin{array}{l}\text { Gal, Ara, } \\
\text { Fuc }\end{array}$ & $\begin{array}{l}\text { Glc unida por enlaces } \beta-(1 \rightarrow 4) \text { con reiduos } \beta \text { - } \\
(1 \rightarrow 6) \text { de Xil. Sustituciones de Ara, Gal, Fuc }\end{array}$ \\
\hline \multicolumn{4}{|l|}{ Sustancias pécticas } \\
\hline Homogalacturonano & AGA & Ram, Xil & $\begin{array}{l}\text { AGA unido por enlaces } \alpha-(1 \rightarrow 4) \text {, parcialmente } \\
\text { esterificado con metanol o acetilado. Algunos } \\
\text { residuos de Ram y Xil }\end{array}$ \\
\hline Ramnogalacturonano & AGA, Ram & $\begin{array}{l}\text { Ara, Gal, } \\
\text { Fuc } \\
\text { Xil }\end{array}$ & $\begin{array}{l}\text { RG tipo I }(1 \rightarrow 2) \operatorname{Ram}(1 \rightarrow 4) \text { AGA con cadenas } \\
\text { laterales de arabinanos y arabinogalactanos. } \\
\text { Algunos AGA están acetilados y las cadenas } \\
\text { contienen Afe }\end{array}$ \\
\hline Arabinanos & Ara & & $\begin{array}{l}\text { Ara unida por enlaces } \alpha-(1 \rightarrow 5) \text { con } \\
\text { ramificaciones } \alpha-(1 \rightarrow 2) \text { y } \alpha-(1 \rightarrow 3)\end{array}$ \\
\hline Arabinogalactanos tipo I & Gal & Ara & $\begin{array}{l}\text { Gal unida por enlaces } \beta-(1 \rightarrow 4) \text { con } \\
\text { ramificaciones de Ara }\end{array}$ \\
\hline Arabinogalactanos tipo II & Gal & Ara & $\begin{array}{l}\text { Gal unida por enlaces } \beta-(1 \rightarrow 3) \text { con } \\
\text { ramificaciones } \beta-(1 \rightarrow 6) \text { de Gal y Ara }\end{array}$ \\
\hline
\end{tabular}

Abreviaturas: Ara: Arabinosa; Fuc: Fucosa; Gal: Galactosa; Glc: Glucosa; AGA: Acido galacturónico; Ram: Ramnosa; Xil: Xilosa; GluA: Acido glucurónico; Afe: Ácido ferúlico.

Los polisacáridos constituyentes de las paredes celulares vegetales representan un alto porcentaje de la biomasa vegetal. Estos determinan gran parte de los atributos de calidad de frutas y vegetales frescos como así también su comportamiento durante el proceso de manufactura de alimentos. Los componentes predominantes en los residuos agroindustriales como rastrojos de cosechas, cáscaras de frutos, fibra de papa, salvado de trigo, etc; algunos de los cuales son reutilizados en la industria de alimentos. Constituyen además una fuente renovable de energía ya que pueden ser convertidos por vía microbiana en compuestos valiosos como etanol. Los residuos vegetales tal cual o algunos polisacáridos extraídos de ellos como la pectina, son utilizados en diversos procesos industriales, cumpliendo funciones como material de relleno, por ejemplo, en la elaboración de textiles, fibra dietética, piensos y papel o bien como aditivo como son los casos de las aplicaciones relacionadas con la elaboración de alimentos, pinturas, cosméticos y productos farmacéuticos. Tales aplicaciones 
dependen de las propiedades físico-químicas y biológicas de los polisacáridos [Voragen et al., 2001].

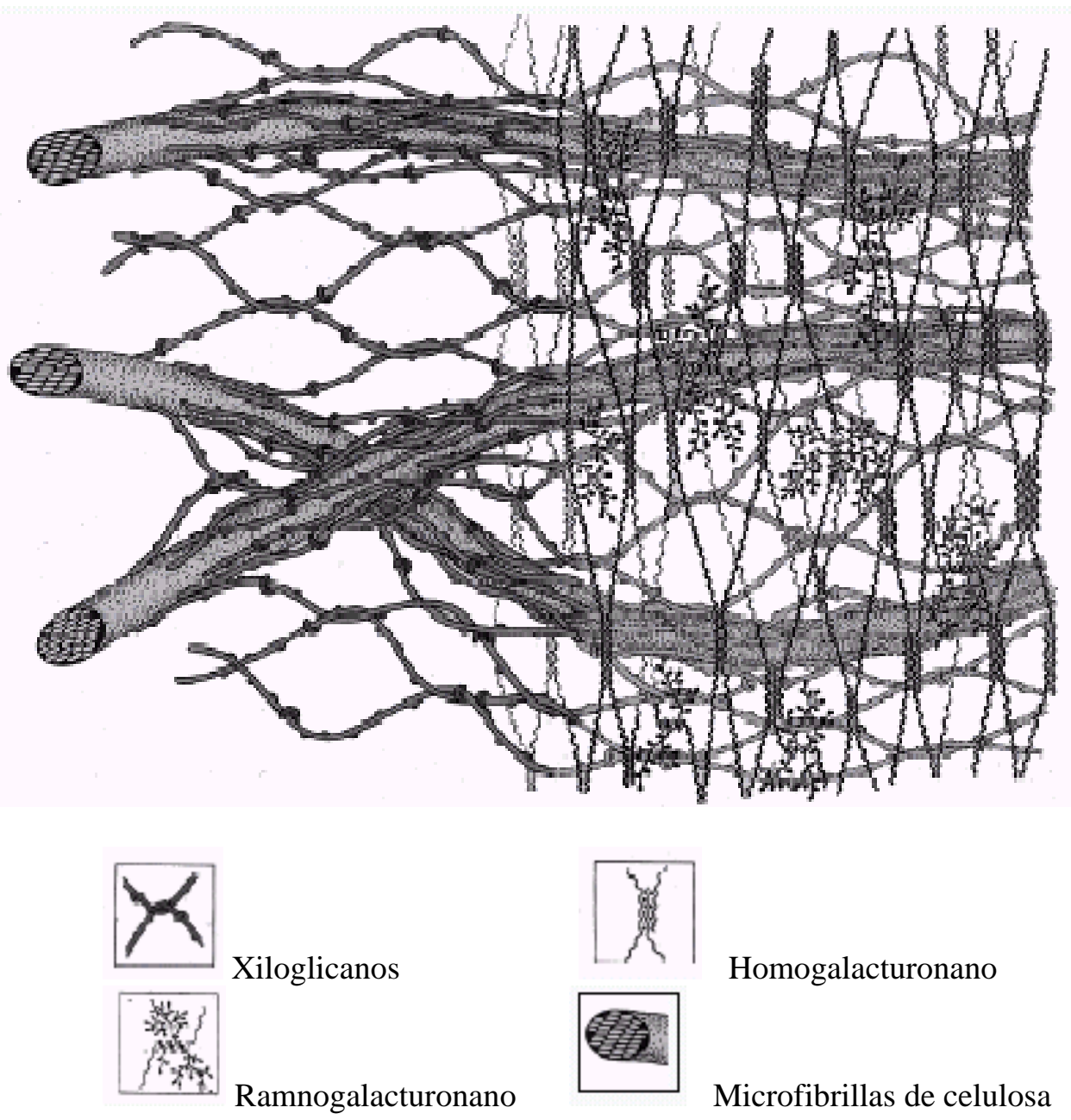

Figura 1.2. Modelo de inserción de polisacáridos de pared celular primaria tipo I correspondiente a plantas fanerógamas [Carpita and Gibeaut, 1993].

\subsection{Las sustancias pécticas}

Las sustancias pécticas son polisacáridos ácidos complejos, que están localizados principalmente en la matríz de la pared primaria y laminilla media de plantas superiores. Actúan como controladoras de la porosidad y difusión pasiva de diversos solutos y participan en la regulación de los procesos de elongación y absición [Jarvis, 1984]. El estudio de las sustancias pécticas tiene interés en áreas de investigación muy diversas tales como: Fisiología Vegetal, Fitopatología (mecanismos de defensa), Ciencia de los Alimentos, en conexión con los cambios de textura que ocurren durante la maduración, el procesamiento de frutas y verduras [Pilnik and Voragen, 1992], y extracción de pectina [May, 1990; Contreras-Esquivel, 
1995]; Nutrición, en relación a su rol como fibra dietética [Baig and Cerda, 1980]; Tecnología Farmacéutica e Industrial, como agente antidiarreico, en el recubrimiento de tabletas de fármacos de liberación prolongada [Rolin et al., 1998], en la preparación de películas biodegradables [Coffin and Fishman, 1994] y para síntesis como co-polímero del poliuretano [Kennedy, 1985]. Históricamente, las sustancias pécticas han sido consideradas como aquellos polisacáridos ácidos de los tejidos vegetales que son extraídos con agua caliente, ácido diluido u oxalato de amonio y otros agentes quelantes [Rolin et al., 1998]. Estas características de solubilidad han permitido clasificar las sustancias pécticas en: pectina soluble en agua, la cual puede ser extraída del tejido vegetal con agua caliente o soluciones salinas diluídas; pectina soluble en agentes quelantes, que se extrae con soluciones de EDTA, CDTA, hexametafosfato, imidazol, etc., y protopectina que se solubiliza por calor en presencia de ácido o álcali [Van Buren, 1991]. Estas características de solubilidad de las sustancias pécticas fueron aceptadas originalmente por la American Chemical Society [1944] y aún son empleadas por algunos investigadores. Los procedimientos de extracción diferencial son convenientes pero no enteramente selectivos, por lo que es recomendable clasificar a los polisacáridos pécticos de acuerdo a sus características estructurales conforme a los procedimientos de aislamiento [Aspinall, 1980, 1982]. En la Tabla 1.2 se resumen los criterios de clasificación de pectinas.

Tabla 1.2. Clasificación de las sustancias pécticas de acuerdo a diferentes criterios.

\begin{tabular}{|c|c|}
\hline $\begin{array}{l}\text { Criterio de } \\
\text { clasificación }\end{array}$ & Componente \\
\hline Solubilidad & $\begin{array}{l}\text { Pectina soluble en agua } \\
\text { Pectina soluble en agentes quelantes } \\
\text { Pectina soluble en álcali o ácidos }\end{array}$ \\
\hline Idem (ACS) & $\begin{array}{l}\text { Acido péctico (pectato)* = ácido poligalacturónico** } \\
\text { Acido pectínico (pectinato)* = pectinas** } \\
\text { Protopectina }\end{array}$ \\
\hline Estructura & $\begin{array}{l}\text { Sobre la base de la cadena principal: homogalacturonano, } \\
\text { ramnogalacturonano I, ramnogalacturonano II, } \\
\text { xilogalacturonano, apiogalacturonano. }\end{array}$ \\
\hline Comercial & $\begin{array}{l}\text { Pectinas de alto metoxilo } \\
\text { Pectinas de bajo metoxilo } \\
\text { Pectinas de bajo metoxilo amidadas } \\
\text { Pectinas acetiladas }\end{array}$ \\
\hline
\end{tabular}

* en forma de sal $\quad$ ** nombre común. ACS: American Chemical Society 


\subsection{Estructura química de las sustancias pécticas}

La estructura química de la pectina está básicamente constituida por dos tipos de polímeros: galacturonanos, cuyo esqueleto principal está formado por residuos de ácido galacturónico (AGA) conectados mediante enlaces $\alpha-(1 \rightarrow 4)$ y ramnogalacturonanos formado por residuos alternados de AGA y ramnosa (Ram) (Figura 1.3).
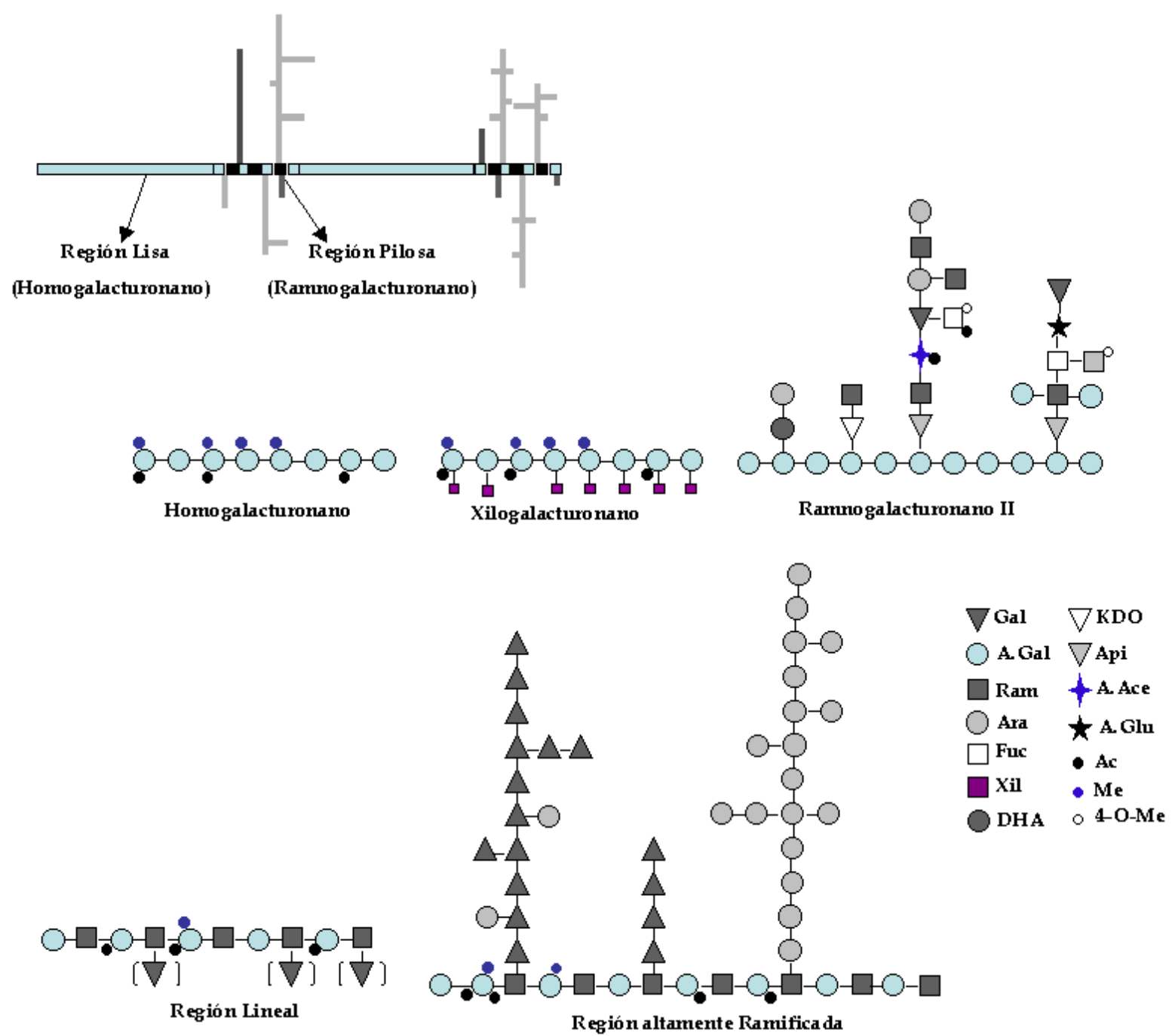

Figura 1.3. Polímeros estructurales de la pectina [Voragen et al., 2001].

Entre los galacturonanos tenemos el homogalacturonano (HG), xilogalacturonano (XG), apiogalacturonano y el llamado ramnogalacturonano II (RGII). El HG es un polímero helicoidal de grado de polimerización estimado en 70-100. El ácido galacturónico presenta algunos substituyentes no glucídicos tales como metanol, ácido acético, ácidos fenólicos, y en 
algunas muestras comerciales, grupos amido [Ridley et al., 2001; Voragen et al., 2001]. El grado de metilación (GM) se define como los moles de metanol presentes cada 100 moles de ácido galacturónico. Las pectinas con valores de GM > 50 se les denomina de alto contenido de metoxilo (cítricos, manzanas) y, en caso contrario, de bajo metoxilo (papa, pera, receptáculos de girasol). La distribución de los metoxilos puede ser aleatoria o por bloques. La laminilla media posee en general un bajo grado de metilación. Además de la esterificación con metanol, algunos grupos hidroxilos en C-2 y C-3 se encuentran acetilados. El grado de acetilación es muy bajo en pectinas de manzanas o cítricos (3-4\%) pero alta en remolacha azucarera o papa (14-20\%). La interacción del HG con iones $\mathrm{Ca}^{+2}$ (se requieren al menos 14 residuos) produce el fenómeno de gelación, que se revela por la precipitación del polímero inducida por la unión del $\mathrm{Ca}^{+2}$ a los grupos carboxilo (Figura 1.4). Debido a que el HG no contiene esencialmente ramificaciones o cadenas laterales, esta región de la pectina es denominada región lisa (smooth region). Además del HG, que es el galacturonano mas estudiado y de mas amplia distribución, se han aislado otros galacturonanos cuyo estrucura resultó ser mas compleja que el HG. El XG se lo aisló de una fracción de pectina de manzana resistente a la degradación enzimática. La xilosa, que se encuentra ocasionalmente en las sustancias pécticas, se halla unida directamente al residuo de ácido galacturónico, siendo el grado de sustitución 0.7. El XG se halla interconectado con las regiones del RG. El galacturonano denominado $R G$-II es un polímero de bajo peso molecular y su estructura es extremadamente compleja. Si bien su nombre sugiere una estructura base similar al $R G-I$ (ver mas adelante), en realidad presenta una cadena de 7 a 12 residuos de ácido galacturónico con uniones $\alpha-(1 \rightarrow 4)$ ramificada en cuatro sitios diferentes con oligosacáridos que se caracterizan por presentar, además de los residuos comunes de ramnosa, galactosa, fucosa y arabinosa, azúcares inusuales tales como: 2-O-metil-fucosa, 2-O-metil-xilosa, apiosa, ácido 2-ceto-3deoxi-D-manano-octulosónico (KDO), entre otros. EL RG-II se encuentra como dímero entrecruzado por un borato diol éster. Este entrecruzamiento está formado entre el H-2 y el H3 de los residuos de apiosa de cada subunidad monómerica del $R G$ - $I I$. El RG-II aislado de diferentes fuentes parece tener una estructura similar [Ridley et al., 2001] y se lo encuentra adyacente al $R G-I$.

El segundo grupo de polímeros constituyentes de la pectina son los ramnogalacturonanos, alguno de los cuales contiene muchas cadenas laterales, por lo que esta región de la pectina se ha denominado región pilosa (hairy region). En realidad, las regiones pilosas contienen RG, pero el RG es solo una parte de esta región (RGII estaría incluido en la región pilosa). Uno de los RG más estudiados, aislado de cultivos celulares en suspensión de muchas especies de 
plantas, se denomina $R G-I$ (en la Figura 1.3) aparece con la denominación "highly branched

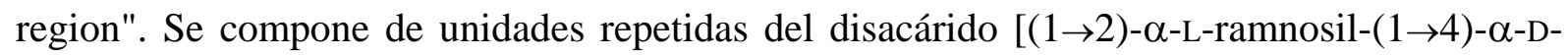
ácido galactosilurónico]. Su longitud no se ha determinado, pero podría contener hasta 300 unidades de cada residuo. La presencia de ramnosa produce una estructura en forma de "T" de la cadena lineal o eje central. Los residuos de ácido galacturónico se hallan generalmente acetilados. Las ramificaciones del polímero ocurren en su mayor parte en el O-4 de los residuos de ramnosa con uniones del tipo $(1 \rightarrow 4)$ y están formadas por residuos ricos en azúcares neutros: arabinosa (arabanos), galactosa (galactanos) y cantidades menores de fucopiranosa. La unión entre los residuos laterales de arabinosa es $(1 \rightarrow 5)$ y entre los residuos de galactosa $(1 \rightarrow 4)$. Los residuos de ramnosa en el $R G-I$ que tienen cadenas laterales varían entre el 20 y el $80 \%$, dependiendo de la fuente de RG. Algunos de estos constituyentes poseen residuos de ácido ferúlico en el extremo no reductor (uniones O-5 con arabinosa y O-3 con galactosa). El RG-I se encuentra prácticamente en todos los tejidos vegetales y en algunos casos representa el 7-14\% de la pared celular. Los arabanos, galactanos y 2 formas de arabano-galactanos (arabano-galactano I y arabano-galactano II) asociados al $R G-I$, se incluyen dentro de las sustancias pécticas [Voragen et al., 2001].

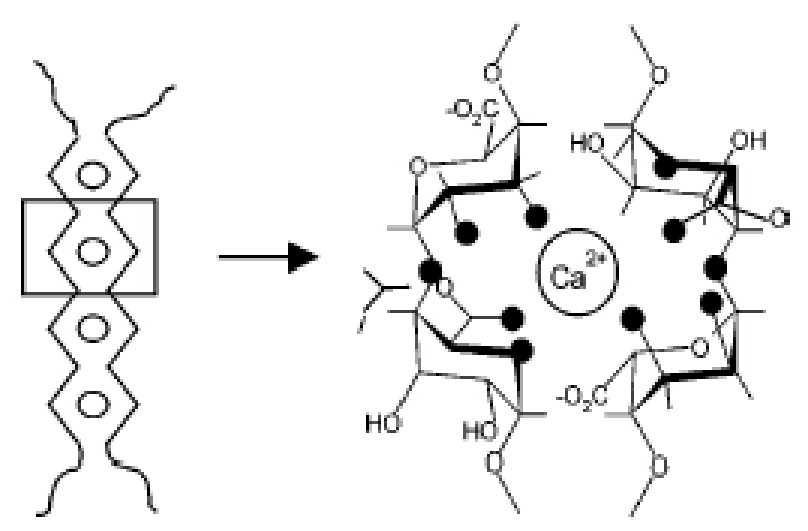

Figura 1.4. Modelo de "caja de huevo" para la estructura de geles de galacturonatos de calcio [Braccini and Pérez , 2001].

En general, las regiones ramificadas son más frecuentes y más grandes en los polímeros pécticos de la pared celular primaria que en la pectina de la laminilla media. Estas regiones, entre otras funciones, mantienen unidas las moléculas de pectina a los otros polímeros constituyentes de la pared celular como proteínas, hemicelulosa y celulosa, resultando en conjunto una estructura insoluble (ver Figura 1.2). Las regiones de HG y RG parecen estar interconectadas ya que la hidrólisis del HG con poligalacturonasas no activas frente a RG, 
solubiliza productos ricos en regiones RG y viceversa, la hidrólisis con enzimas que hidrolizan específicamente RG da lugar a productos ricos en HG. Las regiones del RG-II entrecruzadas con boratos serían aquellas sensibles al pH ácido, que se hidrolizan al disminuir el pH de la pared, permitiendo de este modo la expansión celular. Este proceso es inducido por auxinas. Una función importante de las sustancias pécticas es el control de la porosidad de la pared celular. El mayor efecto sobre la porosidad lo da el entrecruzamiento de las regiones de bajo metoxilo con $\mathrm{Ca}^{+2}$. A esta propiedad contribuiría también la unión de las diferentes cadenas de sustancias pécticas mediante la dimerización de los residuos de ácido ferúlico.

\subsection{Enzimas pectolíticas}

Las enzimas pectolíticas o pécticas, llamadas comúnmente pectinasas, constituyen un complejo sistema de enzimas que incluye hidrolasas, liasas y oxidasas, que intervienen en la degradación o modificación de la pectina. Se encuentran en la mayoría de las plantas superiores y son producidas también por hongos filamentosos [McFeeters et al., 1992], bacterias [Collmer and Keen, 1986; Hugouvieux-Cotte-Pattat et al., 1996] y algunas levaduras [Biely and Kremnicky, 1998] e insectos [Pilnik and Voragen, 1970]. Las pectinasas son en su mayor parte extracelulares, pero otras se localizan intracelularmente y son las responsables del metabolismo de los productos de degradación generados por la acción de las pectinasas extracelulares. Mucho se ha avanzado en el conocimiento de las enzimas involucradas en la biosíntesis de la pectina. Estas incluyen las transferasas, que cumplen la función de unir las unidades monoméricas, incorporar los sustituyentes y generar la estructura final [Mohnen, 1999]. El estudio de las sustancias pécticas y las pectinasas está indisolublemente ligado al avance y mejoramiento de los métodos analíticos usados para determinar estructuras complejas de carbohidratos [Voragen and Schols, 2001].

\subsubsection{Clasificación de las enzimas pectolíticas}

Hasta hace muy poco, las revisiones bibliográficas sobre enzimas pécticas solamente describían las enzimas que actuaban sobre el HG [Rombouts and Pilnik, 1980; Fogarty and Kelly, 1983; Contreras-Esquivel et al., 1997], pero recientemente se han descubierto varias enzimas que actúan sobre la región RGI [Schols, 1995; Mutter, 1997; Vlugt-Bergmans et al., 2000]. En la Tabla 1.3 se presenta la clasificación de las pectinasas.

Las enzimas que actúan sobre el HG y el RG pueden ser divididas en enzimas depolimerizantes y desesterificantes. Las enzimas depolimerizantes se clasifican de acuerdo a los siguientes criterios: 1) tipo de ruptura de los enlaces glicosídicos: hidrolítico o 
transeliminativo, 2) mecanismo de la reacción: tipo exo o endo, y 3) preferencia de actividad respecto del grado de esterificación metílica del sustrato (alto o bajo).

Tabla 1.3. Clasificación de enzimas pécticas de acuerdo a los lineamientos de Comisión de Enzimas y asignación de la familia de hidrolasas.

\begin{tabular}{|c|c|c|c|c|}
\hline & Enzima (nombre trivial) & Código & $\begin{array}{c}\text { Familia de } \\
\text { glicosilhidrolasa }\end{array}$ & $\begin{array}{l}\text { Principales productos de la } \\
\text { reacción o modo de acción }\end{array}$ \\
\hline \multicolumn{5}{|l|}{ Hidrolasas } \\
\hline \multirow{4}{*}{ Esterasas } & Pectin-metilesterasa. & EC 3.1.1.11 & 8 & $\mathrm{HG}$ bajo metoxilo + metanol \\
\hline & Pectin-acetilesterasa. & EC 3.1.1.6 & & $\begin{array}{l}\mathrm{HG} \text { desacetilado }+ \text { ácido } \\
\text { acético }\end{array}$ \\
\hline & $\begin{array}{l}\text { Ramnogalacturonano- } \\
\text { acetilesterasa }\end{array}$ & & 12 & $\begin{array}{l}\text { RGI desacetilado + ácido } \\
\text { acético }\end{array}$ \\
\hline & Feruil-esterasa* & & & RG + ácido ferúlico \\
\hline \multirow{11}{*}{ Glicosidasas } & endo-poligalacturonasa & EC 3.2.1.15 & & oligogalacturonatos + AGA \\
\hline & exo-poligalacturonasa & EC 3.2.1.67 & & AGA, digalacturonato \\
\hline & ramnogalacturonano-hidrolasa & & & hidrólisis AGA-Ram en RGI \\
\hline & $\begin{array}{l}\text { ramnogalacturonano- } \\
\text { galacturónico hidrolasa }\end{array}$ & & & $\begin{array}{l}\text { libera AGA terminal unido a } \\
\text { Ram en RGI ( hidrólisis exo) }\end{array}$ \\
\hline & $\begin{array}{l}\text { ramnogalacturonano- } \\
\text { ramnohidrolasa }\end{array}$ & & & $\begin{array}{l}\text { libera Ram terminal unida a } \\
\text { AGA en RGI ( hidrólisis exo) }\end{array}$ \\
\hline & xilogalacturonano-hidrolasa & & & libera Xil del XG \\
\hline & endo-galactanasa * & & 53 & hidrólisis de galactanos \\
\hline & $\alpha$-galactoisdasa & EC 3.2.1.22 & 27,36 & remoción de residuos Gal \\
\hline & $\beta$-galactosidasa* & EC 3.2.1.23 & 35 & remoción de residuos Gal \\
\hline & endo-arabinasa* & & & hidrólisis de arabanos \\
\hline & $\alpha$-L-arabinofuranosidasa* & & 51,54 & remoción de residuos Ara \\
\hline \multicolumn{5}{|l|}{ Liasas } \\
\hline & pectin-liasa & EC. 4.2.2.10 & & $\begin{array}{l}\text { oligogalacturonatos insaturados } \\
\text { metilados }\end{array}$ \\
\hline & pectato-liasa & EC 4.2.2.2 & & oligogalacturonatos insaturados \\
\hline & ramnogalacturonano-liasa & & & $\begin{array}{l}\text { transeliminación Ram-AGA en } \\
\text { RGI }\end{array}$ \\
\hline
\end{tabular}

\section{Oxidasas}

\footnotetext{
*Enzimas accesorias.
}

Las enzimas desesterificantes se clasifican de acuerdo al tipo de grupo éster que hidrolizan, ya sea metil-, acetil- o feruil-éster. Otras enzimas pécticas, no mencionadas en esta clasificación, son las enzimas intracelulares responsables del metabolismo de los productos de degradación de la pectina. La clasificación de las pectinasas mencionada se refiere a la acción de estas enzimas sobre sustratos solubles. Algunos autores han descrito una clase adicional de pectinasas teniendo en cuenta su acción sobre sustratos insolubles; son las denominadas 
protopectinasas (PPasas). Estas son definidas como enzimas capaces de degradar "protopectina” (la pectina insoluble del tejido vegetal) generando pectina soluble de alto peso molecular [Sakai et al., 1993].Sin embargo, después de la caracterización de varias "PPasas”, se determinó que su mecanismo de acción es similar al descripto para las pectinasas caracterizadas con sustratos solubles (hidrolíticas, transeliminativas, específicas de la región HG o del RG). Mas aún, se ha demostrado que el gen que codifica la actividad “protopectinasa” de Trichosporum penicillatum muestra una consistente homología con las clásicas poligalacturonasas [Iguchi et al., 1997; Pareniková, 2000]. Por lo tanto, si bien en diversas revisiones bibliográficas se incluyen a las PPasas como grupo adicional dentro de la clasificación de las enzimas pécticas, no existirían razones para considerarlas como tal y la actividad "protopectinasa” debe considerarse como una actividad natural de ciertas enzimas pectolíticas, aunque algunas de ellas puedan ser más eficientes que otras en hidrolizar protopectina [Schols, 1995]. Un importante paso para la clasificación de las glicosidasas ha sido su agrupación en 28 familias sobre la base de similitudes en la secuencia. En esta agrupación se incluye las pectinasas [Henrisstat, 1991].

\subsubsection{Breve descripción de las enzimas pectolíticas}

\section{Enzimas que atacan el esqueleto principal de los polímeros pécticos}

Poligalacturonasas (PGasas): actúan básicamente sobre el HG hidrolizando las uniones glicosídicas entre residuos no estrificados y pueden ser divididas en tres grupos de acuerdo a su acción sobre el sustrato ácido poligalacturónico (APG): endo-PGasas que atacan el sustrato en forma aleatoria generando mezclas de oligómeros, tri y digalacturonatos y AGA; las exoPGasas tipo I (galacturonan $\alpha-(1 \rightarrow 4)$-galacturonosidasa) que liberan AGA del extremo no reductor y las exo-PGasas tipo II (exo-poli- $\alpha$-galacturonosidasa) que liberan digalacturonato del extremo no reductor. Las endo-PGasas y exo-PGAsa tipo I fueron identificadas en varios hongos filamentosos y han sido estudiadas extensamente [Parenicová, 2000].

Polimetilgalacturonasa: esta enzima degradaría el HG altamente metoxilado, aunque su existencia es fuente permanente de controversia. Algunos reportes sobre la presencia de dicha actividad enzimática se atribuyen en realidad a la actividad de la PGasa contaminada con pectin-metilesterasa [Rombouts and Pilnik, 1980].

Pectin- y pectato-liasas: estas enzimas degradan el HG mediante un mecanismo de transeliminación, introduciendo un doble enlace entre el C-4 y el C-5 del extremo no reductor formado en la reacción. Las HG liasas se dividen en aquellas que degradan pectina con bajo grado de metoxilación (pectato-liasas) y las que hidrolizan pectina altamente metoxilada 
(pectin-liasas, PeL). No se han encontrado liasas en plantas y la fuente más común de estas enzimas son las bacterias y hongos filamentosos, en particular los fitopatógenos. Las pectatoliasas requieren $\mathrm{Ca}^{+2}$ para su actividad, pero no así la PeL. Otras liasas descriptas son la exopectatoliasa y las oligogalacturonato liasas, las cuales a diferencia de las exo-poligacturonasas y las oligogalacturonato hidrolasas, atacan el sustrato desde el extremo reductor [Wang, 1995].

Enzimas que actuán sobre el RG: la primera descripción de una enzima capaz de degradar la cadena principal del RGI fue hecha en 1990 y se denominó ramnogalacturonasa (RGasa). El nombre actual es $\alpha$-D-galactopiranosilurónico-(1,2)- $\alpha$-L-ramnopiranosil hidrolasa que se abrevia RG-hidrolasa. La enzima hidroliza la unión AGA-Ram en el esqueleto principal del RG. Mas recientemente se ha descripto otras enzimas que degradan RG: RG-liasa, que corta la unión Ram-AGA del esqueleto principal y dos enzimas que actúan en forma exo: RGramnohidrolasa que remueve una Ram terminal del extremo no reductor del RG y RGgalacturonanohidrolasa que remueve AGA terminal del extremo no reductor de RG [Voragen et al. , 2001].

Enzimas que degradan las cadenas laterales de los polímeros pécticos y remueven sustituyentes de la cadena principal (enzimas accesorias).

Además de las enzimas descriptas, existen otras que están involucradas en la degradación de las ramificaciones o en la desesterificación de la pectina y se han denominado enzimas accesorias. Algunas de estas enzimas actuarían también sobre otros polisacáridos constituyentes de la pared celular, en particular la hemicelulosa, dependiendo el enlace específico que la enzima reconoce. La mayor parte de las enzimas auxiliares o accesorias se han estudiado en bacterias y hongos filamentosos, en particular los del género Aspergillus [de Vries, 1999]. Entre las enzimas accesorias tenemos:

$\alpha$-L-Arabinofuranosidasas y arabinoxilano arabinofuranohidrolasa: las primeras son mas bien inespecíficas y remueven residuos Ara unidos por enlaces $\alpha-1,2-, \alpha-1,3-, \alpha-1,5-$ de diversos sustratos, entre ellos los arabanos laterales de las pectinas. La segunda es muy específica de residuos Ara unidos a xilosa y es una enzima involucrada en la degradación de la hemicelulosa.

Endo-arabinasas: hidrolizan en forma aleatoria las uniones $\alpha-1,5$ de los arabanos, potenciando la acción de las arabinofuranosidasas.

$\alpha$ - y $\beta$-Galactosidasas: remueven residuos $\mathrm{Gal}$ de los galactanos laterales de las pectinas. 
Endo- y exo-galactanasas: junto a la $\beta$-gal son requeridas para la degradación completa de las cadenas laterales de galactano y arabinogalactano presente en las pectinas. Si bien los enlaces presentes en estas estructuras son del tipo $\beta-1,3-, \beta-1,4-, \beta-1,5-$, la mayoría de las endo-galactanasas estudiadas muestran preferencia por las uniones $\beta-1,4-$. La única exogalactanasa descripta libera Gal de galacto-oligosacáridos y posee actividad transferasa.

Feruloil- y p-coumaril-esterasas: estas enzimas remueven los residuos feruloíl- y coumaroílque se encuentran esterificando al O-5 en xilanos y al O-3 en Ara u O-6 en Gal de las pectinas. Debido a la propiedad de estos residuos de producir entrecruzamiento entre la pectina y xilano con los otros polisacáridos de la pared como lignina, la acción de estas enzimas es importante para la integridad de la pared. Están muy difundidas en bacterias y hongos filamentosos.

Acetil- y metil-esterasas: las pectin acetil o metil esterasas remueven grupos metilo y acetilo de la región del HG, y han sido encontrada en plantas superiores, numerosos hongos, levaduras y bacterias. También se ha descripto una ramnogalacturonano acetil esterasa que remueve acetilos del RG y es esencial para la acción de la RG-hidrolasa. Otra esterasa muy estudiada es la acetil-xilano esterasa, que remueve los grupos acetilo que esterifican el O-3 de la cadena principal del xilano y facilita la degradación de este polímero por las endoxilanasas.

Otras enzimas: otras enzimas con acción sobre la pectina incluyen la galacturónico oxidasa o ácido urónico oxidasa, la cual oxida el ácido galacturónico en presencia de oxígeno a ácido galactárico y $\mathrm{H}_{2} \mathrm{O}_{2}$; las transferasas que contribuyen a la síntesis de los polisacáridos pécticos (se estima que se requieren más de 53 enzimas para llevar a cabo dicho proceso) y el conjunto de enzimas intracelulares responsables del metabolismo de los ácidos urónicos y otros. El papel exacto de la oxidasa no ha sido descripto, pero se postula que está involucrada en la modificación de componentes de la pared celular vía oxidación del ácido poligalacturónico como defensa de la planta [Pressey, 1991]. Aún no ha sido descripta esta enzima en microorganismos. En las Figuras 1.3 se presenta un esquema de la acción degradativa de las enzimas pectolíticas.

\subsubsection{Aplicaciones de las enzimas pectolíticas}

Las enzimas pectolíticas se han aplicado en la industria de bebidas y alimentos por más de 60 años. La fuente principal de su producción son hongos del género Aspergillus [Voragen and Pilnik,1988]. Este microorganismo, como otros, produce diferentes enzimas pécticas en respuesta a las condiciones de cultivo, obteniéndose al final de la fermentación un cultivo que 
contiene una mezcla compleja de enzimas que degradan tanto pectina como otros polisacáridos de la pared celular. Mediante el clonado de los genes correspondientes y la sobre expresión, estas enzimas pueden producirse en concentraciones equivalentes a mg/l ó g/l de proteína enzimática [Dalbøge, 1997]. Los procesos con cepas recombinantes permiten a la vez obtener cultivos en los cuales la proteína de interés es producida con un mínimo o nula presencia de otras enzimas, lo cual facilita enormemente el proceso de recuperación. Al disponer de enzimas puras en cantidades industriales, se pueden formular mezclas óptimas para cada aplicación particular (tailor-made), lo cual es muy ventajoso en comparación con el uso de mezclas complejas, muchas veces incompletamente caracterizadas, obtenidas mediante el cultivo con cepas nativas en procesos tradicionales.
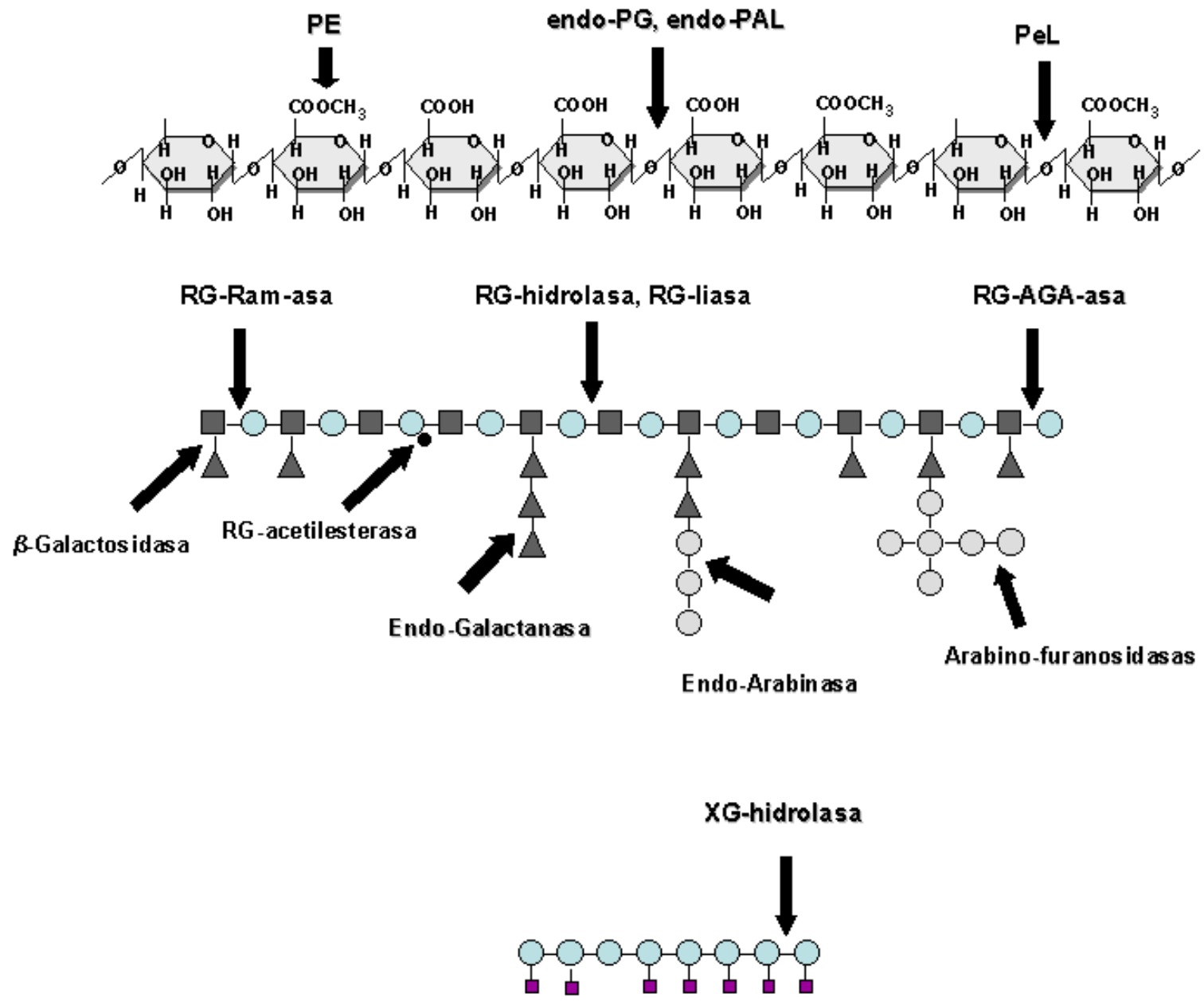

Figura 1.4. Degradación de fragmentos de sustancias pécticas por enzimas pectolíticas específicas [Voragen et al., 2001]. 
La aplicación más tradicional de las pectinasas, es en la clarificación de jugos. El jugo que resulta luego del prensado de la fruta, por ejemplo de manzana o uva, es turbio debido a la presencia de fragmentos de pared celular y a complejos formados por proteínas positivamente cargadas rodeadas de una capa de pectina con carga negativa. La repulsión de estos complejos entre si los mantiene en suspensión [Pilnik and Rombouts, 1979]. El agregado de una mezcla de PGasa y PME o PeL sola, produce la degradación de la capa externa de pectina, promoviendo la interacción electrostática de los complejos, su precipitación y la consiguiente clarificación del jugo. En algunos casos, la pérdida de turbidez del jugo es indeseable, como en los jugos cítricos destinados al consumo. Cuando los frutos se exprimen, la PME endógena desmetoxila la pectina y promueve su interacción con el $\mathrm{Ca}^{+2}$ presente en el jugo, dando lugar a la precipitación del pectato de calcio y la consiguiente autoclarificación. La degradación parcial de la pectina mediante el uso selectivo de una PGasa o PeL, genera productos de bajo peso molecular no precipitables con el calcio y de este modo evita la autoclarificación [Bonnin et al., 1997]. Otra aplicación es el llamado enzimado de pulpa (pulp enzyming). En este caso, las pectinasas se adicionan a la masa prensada de frutas, generalmente las que contienen mucha pectina, por ej.: frutillas, cerezas, grosellas, frambuesas e incluso manzanas y uvas. Las pectinasas degradan la pectina que causa la gelificación de la pulpa, facilitando el proceso de filtración. Este proceso se ha aplicado también para aumentar el rendimiento del prensado en la producción de aceite de oliva, palma y coco.

Otro proceso de gran interés es la maceración, cuyo objetivo es degradar la laminilla media del tejido vegetal para producir células libres relativamente intactas [Pilnik and Romboust, 1981; Renard, 1989, Nakamura et al., 1995]. Dicho proceso fue originalmente desarrollado para obtener bebidas viscosas, turbias y con pulpa, llamadas néctares. Alguna de las frutas usadas para estos productos son las peras, duraznos, damascos, papaya, maracuyá y guayaba. De igual modo, la maceración es empleada para obtener purés de vegetales como zanahorias, morrones u otros, con alto contenido de sólidos, pigmentos y vitaminas, que se emplean en la alimentación de bebés y adultos mayores, y como aditivos alimentarios. Las enzimas preferentemente empleadas para la maceración de los tejidos vegetales, son las PGasas y PeL. En este proceso, la presencia de PME (tanto endógena como exógena) es indeseable pues la acción de esta enzima transformaría el proceso de maceración en un enzimado de pulpa [Pilnik and Voragen, 1991; 1993].

A través de la acción combinada de pectinasas y celulasas se puede lograr la degradación completa de la pared celular dando lugar a la lisis y la consiguiente liberación del jugo celular. Este proceso conocido como licuefacción se aplicó a la producción de jugos de frutas difíciles 
de filtrar como mango, banana o guayaba. Este proceso presenta una restricción importante, el uso de celulasas purificadas en la elaboración de alimentos no es aceptado por las agencias regulatorias. Un proceso alternativo muy difundido es el llamado licuefacción del orujo (pomace liquefaction), que involucra el prensado de la pulpa y la obtención de jugo y el respectivo orujo. Luego el orujo se diluye en agua, se licuefacciona y se vuelve a filtrar obteniéndose un segundo jugo. Esta alternativa es corrientemente empleada en la elaboración de jugos de manzana y ananá.

Tabla 1.4. Aplicación tecnológica de enzimas pectolíticas (modificado de Grassin and Frauquemberge, 1996)

\begin{tabular}{|c|c|c|c|}
\hline Enzima & Importancia & Papel tecnológico & Aplicación \\
\hline PeL & +++ & \multirow{4}{*}{ Procesado de frutas } & \multirow{4}{*}{$\begin{array}{l}\text { Extracción de jugo de } \\
\text { manzana }\end{array}$} \\
\hline Exo- y exo-Arasa & + & & \\
\hline RG-hidrolasa & + & & \\
\hline PAE & + & & \\
\hline PME & +++ & \multirow{7}{*}{ Despectinización de jugos } & \multirow{7}{*}{$\begin{array}{l}\text { Jugos concentrados } \\
\text { clarificados de } \\
\text { manzana, pera, y } \\
\text { uva }\end{array}$} \\
\hline PGasa & +++ & & \\
\hline PeL & ++ & & \\
\hline Exo- y endo-Arasa & + & & \\
\hline Galasa & + & & \\
\hline RG-hidrolasa & + & & \\
\hline PAE & + & & \\
\hline PME & +++ & $\begin{array}{l}\text { Formación de pectato de } \\
\text { calcio }\end{array}$ & Cidra francesa \\
\hline Arasa & ++ & \multirow{3}{*}{ Hidrólisis de gomas } & Jugo de piña \\
\hline Galasa & ++ & & clarificado \\
\hline PGasa & + & & \\
\hline PGasa & +++ & \multirow{5}{*}{$\begin{array}{l}\text { Despectinización de } \\
\text { Mostos }\end{array}$} & \multirow{5}{*}{$\begin{array}{l}\text { Clarificación de } \\
\text { mosto de uva }\end{array}$} \\
\hline PME & + & & \\
\hline PeL & + & & \\
\hline Arasa & + & & \\
\hline Galasa & + & & \\
\hline PME & +++ & $\begin{array}{l}\text { Desmetoxilación de pectina } \\
\text { endógena }\end{array}$ & $\begin{array}{l}\text { Incremento de textura en } \\
\text { vegetales }\end{array}$ \\
\hline PME & +++ & $\begin{array}{l}\text { Desmetoxilación de pectina } \\
\text { endógena }\end{array}$ & $\begin{array}{l}\text { Extracción de jugo de } \\
\text { manzana }\end{array}$ \\
\hline PGasa & +++ & $\begin{array}{l}\text { Hidrólisis de pectinas } \\
\text { endógenas }\end{array}$ & Extracción de pectina \\
\hline PGasa & +++ & $\begin{array}{l}\text { Hidrólisis de ácido } \\
\text { poligalacturónico }\end{array}$ & $\begin{array}{l}\text { Galacturónico- } \\
\text { oligosacaridos }\end{array}$ \\
\hline PGasa & +++ & Hidrólisis de pectinas & $\begin{array}{l}\text { Decorticado enzimático de } \\
\text { cítricos }\end{array}$ \\
\hline
\end{tabular}

PeL: pectin-liasa; Arasa: Arabinasa; RG-hidrolasa: ramnogalacturonano-hidrolasa; PAE: pectin-acetilesterasa; PME:pectin-metilesterasa: PGasa:poligalacturonasa; Galasa:galactanasa.

Además de los procesos mencionados, las pectinasas son empleadas como auxiliares tecnológicos en alimentos, para el desgomado y biorefinado (bioscouring) de fibras textiles, 
producción de papel, tratamiento de madera, alimentación animal, producción de detergentes y tratamiento de aguas residuales [Shivakumar and Nand., 1995; Hoondal et al., 2002; Rättö and Viikari, 1996;]. Son también empleadas como herramientas analíticas en fitoquímica, en particular en estudios sobre la estructura de la pared celular vegetal, química de polisacáridos, y para la producción de oligosacáridos y polisacáridos con propiedades farmacológicas [McCleary, 1986; Yamada, 1994]. Algunas aplicaciones industriales de las enzimas pectolíticas son presentadas Tabla 1.4.

\subsection{Aspergillus kawachii.}

Algunos hongos del género Aspergillus son usados tradicionalmente en países orientales en la fermentación de granos para la producción de alimentos y bebidas. Las especies más importantes de estos hongos son: A. tamarii, A. oryzae, A. sojae, A. awamori, A. usami y A. kawachii [Cook and Campbell-Platt, 1993]. Aspergillus kawachii, el hongo blanco, se distingue por ser un hiper productor de ácido cítrico y su empleo está muy difundido en la elaboración de vino [Toyama and Toyama, 1997; Lee, 2001]. En la Tabla 1.5 se indican los procesos en los cuales A. kawachii se emplea como iniciador de la fermentación. El objeto de la acción fúngica es degradar los polisacáridos de los granos para producir el sustrato (mosto) el cual es luego inoculado para la fermentación alcohólica (proceso equivalente al malteado).

Tabla 1.5. Empleo de A. kawachii como iniciador de fermentación en la elaboración de bebidas y alimentos en China, Corea y Japón.

\begin{tabular}{|c|c|c|c|c|c|}
\hline Producto & $\begin{array}{l}\text { Nombre } \\
\text { popular }\end{array}$ & País & Iniciador* & $\begin{array}{c}\text { Ingrediente } \\
\text { principal }\end{array}$ & Referencia \\
\hline Vino & Shochu & Japón & Shochu-koji & $\begin{array}{l}\text { Arroz, cebada o } \\
\text { batata. }\end{array}$ & $\begin{array}{c}\text { Teramoto et al., } 1994 \\
\text { Obayashi and Uchi, } 1999 \\
\text { Setoguchi et al., } 1999\end{array}$ \\
\hline Cerveza & Takju & Corea & A. kawachii-Nuruk & Arroz, trigo. & So et al., $1999 \mathrm{ab}$ \\
\hline Sazonador & Mirin & Japón & Shohu-koji & Arroz & Nunokawa et al., 1982 \\
\hline Pasta soja & Kochujang & Corea & A. kawachii-Meju & Soja, ají o chile & Lee et al., 1984 \\
\hline Vino & Tipo sake & Japón & Shochu-koji & Arroz & $\begin{array}{l}\text { Kawai et al., } 1977 \\
\text { Chiyogiku, } 1982 \\
\text { Shimamura et al., } 2001\end{array}$ \\
\hline Vino & - & China & A. kawachii & $\begin{array}{l}\text { Jugos, ácido } \\
\text { acético. }\end{array}$ & Zhang and Yang,, 2001 \\
\hline
\end{tabular}

\footnotetext{
* Iniciador: nombre dado al hongo de acuerdo a la región y tipo de producto
} 


\subsection{Enzimas de Aspergillus kawachii}

El proceso principal durante la preparación de shochu-koji es la degradación enzimática (sacarificación) de los polisacáridos del grano. Debido al carácter ácido de la fermentación (pH 2.0-3.5), las enzimas extracelulares de A. kawachii suelen ser mas estables y activas en estas condiciones en comparación con enzimas similares producidas por otros microorganismos. La condición de acidez se refiere a valores de $\mathrm{pH} \leq 3.0$, rango que no necesariamente coincide con el óptimo para su actividad. En la Tabla 1.6 se detallan las hidrolasas de A. kawachii que han sido purificadas y caracterizadas. Varias de estas han sido clonadas y expresadas en Saccharomyces (Tabla 1.7). La mayoría de las enzimas estudiadas están involucradas en la degradación del almidón, celulosa, hemicelulosa y proteínas .

Tabla 1.6. Propiedades de algunas enzimas purificadas de Aspergillus kawachii.

\begin{tabular}{|c|c|c|c|c|c|c|}
\hline Enzima & $\mathbf{P M}$ & pI & pH óptimo & $\begin{array}{l}\text { Rango } \\
\text { de pH }\end{array}$ & $\begin{array}{c}\text { Temperatura } \\
\text { óptima }\end{array}$ & Referencias \\
\hline \multicolumn{7}{|l|}{ Amilasas } \\
\hline Amilasa I & 104 & 4.25 & $4-5$ & $2.5-6.0$ & 70 (pH 5) & Mikami et al. (1987) \\
\hline Amilasa II & 66 & 4.20 & 5 & $2.5-6.0$ & 70 (pH 5) & “ \\
\hline Amilasa A1 & 85 & - & 5 & $2.0-6.5$ & - & Sudo et al. (1994) \\
\hline Amilasa A2 & 50 & - & 5 & $4.5-9.5$ & - & “ \\
\hline Amilasa A3 & 56 & - & - & - & - & Omori et al. (1994) \\
\hline Glucoamilasa & 101 & - & $4-5$ & $3-8$ & - & Mikami et al. (1989) \\
\hline \multicolumn{7}{|l|}{ Proteasas } \\
\hline Carboxylproteinasa & 35 & 3.9 & 2.8 y 3.4 & $2.2-6.4$ & 50 & Yagi et al. (1986) \\
\hline \multicolumn{7}{|l|}{$\beta$-Glucosidasas } \\
\hline Glucosidasa EX -1 & 145 & - & - & $2-9$ & 30 & Iwashita et al. (1998) \\
\hline Glucosidasa EX -2 & 130 & - & - & $2-9$ & 30 & “ \\
\hline Glucosidasa CB -1 & 120 & - & - & $2-9$ & 30 & “ \\
\hline \multicolumn{7}{|l|}{ Celulasas } \\
\hline \multicolumn{7}{|l|}{ Xilanasas } \\
\hline endo-xilanasa A & 35 & 6.70 & 5.5 & $3-10$ & 60 & Ito et al. (1992b) \\
\hline endo-xilanasa B & 26 & 4.40 & 4.5 & $3-10$ & 55 & “ \\
\hline endo-xilanasa C & 29 & 3.50 & 2.0 & $1-9$ & 50 & “ \\
\hline
\end{tabular}

Tabla 1.7. Enzimas clonadas de A. kawachii y su expresión en diferentes cepas de Saccharomyces cerevisiae.

\begin{tabular}{lccc}
\hline Enzima & $\begin{array}{c}\text { Gen } \\
\text { promotor }\end{array}$ & $\begin{array}{c}\text { Huésped } \\
\text { (cepa de } \text { S. cerevisiae) }\end{array}$ & Referencia \\
\hline Amilasa & AsaA & DBY747 & Kaneko et al., 1996 \\
Celulasa & CMCaseI & DBY747 & Sakamoto et al., 1995 \\
Glucoamilasa & GlaA & - & Morimura et al., 1999 \\
Xilanasa A & $X y n A$ & DBY747 & Ito et al., 1992c \\
Xilanasa C & $X y n C$ & Y294 & Ito et al., 1992a \\
Xilanasa C & $X y n C$ & DBY747 & Crous et al., 1995 \\
\hline
\end{tabular}


Con respecto al sistema pectolítico de A. kawachii, el mismo ha sido muy poco estudiado. Existe un primer reporte al respecto en el cual se describe la separación de dos enzimas activas frente a ácido péctico, sobre la base de su adsorción a Amberlite IRC-50 [Hayashi, 1958]. La fracción que se adsorbe mostró un pH óptimo de 5.4-5.5 frente a APG en buffer fosfato y capacidad para desintegrar cortes de papa (denominada actividad despolimerizante). La fracción no adsorbida mostró un pH óptimo de 4.4-4.5 (APG en buffer acetato) y no desintegró cortes de papa. En un segundo trabajo del año 1961 se describieron dos PGasas, denominadas licuefaccionante y sacarificante, en analogía con la terminología empleada para describir la acción de las amilasas [Junjro et al., 1959]. La primera de ellas, que se refiere a la acción de tipo endo, mostró actividad macerante frente a cortes de papa, mientras que la PGasa sacarificante no mostró capacidad de maceración. Dadas las propiedades de estas enzimas, es probable que fueran similares o idénticas a las reportadas en el primer trabajo. Mas recientemente, durante la realización del presente trabajo de Tesis, se describió la purificación de tres poligalacturonasas producidas por la cepa de A. kawachii IFO 4033 durante su crecimiento en medio líquido con harina de soja a pH 2.0 y 5.0 (valores iniciales). En dicho trabajo se postula que la síntesis de las PGasas depende del pH del medio [Kojima et al., 1999].

\subsection{Objetivos y plan de tesis.}

El desarrollo de nuevas aplicaciones de las pectinasas depende de la búsqueda de enzimas que catalizen reacciones novedosas o que presenten propiedades diferentes a las ya estudiadas. Considerando la capacidad de A. kawachii de producir enzimas activas en condiciones de alta acidez y al escaso conocimiento de su sistema pectolítico, se inició un proyecto de investigación dirigido a estudiar las pectinasas de este microorganismo. El presente trabajo de Tesis se enmarcó en los objetivos de dicho proyecto y se relacionó con el screening de actividades enzimáticas, la purificación y caracterización de una PGasa activa sobre sustratos solubles e insolubles a valores bajos de pH (2.0-3.0) y su aplicación a la extracción enzimática de pectina y la maceración de tejidos. El trabajo se extendió a la purificación y caracterización de poligalacturonasas no-ácidas y al estudio del fenómeno de adsorción selectiva de estas PGasas a filtros de fibra de vidrio. Dicho fenómeno fué observado durante los estudios preliminares de screening y constituyó un aporte original no previamente contemplado en los objetivos iniciales del proyecto. A continuación se detalla el plan desarrollado en el presente trabajo. 
Plan de Tesis

\section{Screening de enzimas pectolíticas (Capítulo 2)}

Cultivos de A. kawachii en medios líquidos con diferentes fuentes de carbono para el screening de enzimas. Desarrollo de un test en placa y zimograma para detectar actividad frente a RG. Caracterización preliminar de la actividad solubilizadora de pectina.

\section{Purificación y propiedades de una poligalacturonasa ácida (Capítulo 3)}

Purificación de una PGasa ácida (PGI) parcialmente constitutiva producida en un medio con glucosa. Determinación de sus propiedades fisico-químicas y cinéticas, modo de acción (exo/endo), estabilidad térmica y especificidad de sustrato.

Empleo de poligalacturonasas en procesos de extracción de pectina y maceración de tejidos vegetales ( Capítulo 4)

Ensayos de maceración de frutas y hortalizas y extracción de pectina de pomaza de limón con la PGI de A. kawachii. Comparación de la pectina extraída enzimáticamente a pH ácido con pectinas extraídas por métodos químicos y con PGasa de A. niger.

Adsorción de PGasas no-ácidas de A. kawachii a filtros de fibra de vidrio. Purificación y propiedades de las PGasas (Capítulo 5)

Estudio del fenómeno de adsorción de pectinasas a filtros de fibra de vidrio. Purificación y caracterización de las PGasas involucradas en el proceso de adsorción.

\subsection{Bibliografía.}

American Chemical Society (1944). Report of Committee for revision of nomenclature of pectic substances. Chem. Eng. News, 22:105-106.

Aspinall, G.O. (1980). Chemistry of Cell Wall Polysaccharides. In: The Biochemistry of Plants. A comprensive treatise. Vol. 3. Carbohydrates: Structure and Function. Preiss. J. (Ed.). Academic Press:New York. pp:473-500.

Aspinall, G.O. (1982). Analysis of polysaccharides. In: Food Carbohydrates. Lineback, D.R. and Inglett, G.E. (Eds.). AVI Publishing Company, Inc: Westport Connecticut. pp:356374.

Baig, M.M. and Cerda, J.J. (1980). Studies on the role of citrus in health and disease. In: Citrus Nautrition and Quality. S. Nagy and J.A. Attaway (Eds.). ACS Syposium Series 143. Amercian Chemical Society: Washington, D.C. pp:25-41. 
Biely, P. and Kremnicky, L. (1998). Yeast and their enzyme systems degrading cellulose, hemicellulose and pectin. Food Technol. Biotechnology, 36:305-312.

Bonnin, E.; Renard, C.; Thibault, J.-F.; Ducroo, P. (1997). Les enzymes de dégradation des parois végétales: mode d'action et utilisations alimentries. Dan: Enzyms an AggroAlimentaire. Laneta-Ganda, V. (Ed.). Tech et Doc Lavoisier: Paris. pp:167-200.

Carpita, N.C. and Gibeaut, D.M. (1993). Structural models of primary cell walls in flowering plants: consistency of molecular structure with the physical properties of the walls during growth. The Plant Journal, 3:1-30.

Coffin, D.R. and Fishman, M.L. (1994). Mechanical properties of pectin-starch films. In: Polymers from Agricultural Coproducts. ACS Symposium Series 575. Washington, D.C.: Amercian Chemical Society, pp:82-91.

Contreras-Esquivel, J.C. (1995). Avances y perspectivas en la producción de pectina. En: La Investigación y el Desarrollo Tecnológico. México: SEP-CONACyT-Estado de Coahuila, México. pp. 30-43.

Contreras-Esquivel, J.C.; Hours, R.A.; Aguilar, C.N.; Reyes-Vega, M.L. y Romero, J. (1997). Revisión: extracción microbiológica y enzimática de pectina. Archivos Latinoamericanos de Nutrición, 47:208-216.

Chiyogiku, K.K. (1982). Manufacture of wine-like sake. Jpn. Kokai Tokkyo Koho JP 82 02,676 .

Collmer, A. and Keen, N.T. (1986). The role of pectic enzymes in plant pathogenesis. Annual Review Phytopathology, 24:383-409.

Cook, P.E. and Campbell-Platt, G. (1993). Aspergillus and fermented foods. In: The Genus Aspergillus. K.A. Powell, A. Renwick, A. y J.F. Peberdy (Eds.). Plenum Press: New York. pp: 171-188.

Crous, J.M.; Pretorius, I.S. and van Zyl, W.H. (1995). Cloning and expression of an Aspergillus kawachii endo-1,4- $\beta$-xylanase gene in Saccharomyces cerevisiae. Curr. Genet., 28:467-473.

Dalboge, (1997). Expression cloning of fungal enzyme genes; a novel approach for efficient isolation of enzyme genes of industrial relevance. FEMS Microbiology Reviews, 21:29-42.

Fry, S.C. (1986). Cross-linking of matrix polymers in the growing cell walls of angiosperms. Ann. Rev. Plant Physiol., 37:165-186.

Fry, S.C. (1995). Polysaccharide-modifying enzymes in the plant cell wall. Ann. Rev. Plant Pysiol. Plant Mol. Biol., 46:497-520. 
Fogarty, W.M. and Kelly, C.T. (1983). Pectic enzymes. In: Microbial Enzymes and Biotechnology. W. Fogarty (Ed.). Applied Science Publishers: New York. pp:131-182.

Grassin, C. and Fauquembergue, P. (1996). Application of pectinases. In: Pectins and Pectinases. J.Visser and A.G.J. Voragen (Eds). Elsevier Science B.V.: The Netherlands. Pp:453-462.

Hayashi, T. (1958). The pectic enzyme produced by microorganisms. I. Pectin galacturonase of Aspergillus kawachii. Hakko Kôaku Zzasshi, 36:246-248.

Henrissat, B.; Bairoch, A. (1993). New families in the classification of glycosyl hydrolases based on amino acid sequence similarities. Biochem. J. 293:781-788.

Hoondal, G.S.; Tiwari, R.P.; Tewari, R.; Dahiya, N. and Beg, Q. K. (2002). Microbial alkaline pectinases and their industrial applications: a review. Applied Microbiology Biotechnology, 59:409-418.

Hugouvieux-Cotte-Pattat, N.; Condemine, G.; Nasser, W.and Reverchon, S. (1996). Regulation of pectinolysis in Erwinia chrisanthemi. Annual Review Microbiology, 50:213257.

Iguchi, K.I.; Hirano, H.; Kishida, M.; Kawasaki, H. and Sakai, T. (1997). Cloning of a protopectinase gene of Trichosporon penicillatum and its expression in Saccharomyces cerevisiae. Microbiology, 143:1657-1664.

Ito, K.; Iwashita, K. and Iwano, K. (1992a). Note. cloning and sequencing of the xynC gene encoding acid xylanase of Aspergillus kawachii. Biosci. Biochem. Biotech., 56:1338-1340.

Ito, K.; Ogasawara, H.; Sugimoto, T.; and Ishikawa, T. (1992b). Purification and properties of acid stable xylanases from Aspergillus kawachii. Biosci. Biotech. Bichem. 56:547-550.

Ito, K.; Ikemasu, T. and Ishikawa, T. (1992c). Cloning and sequencing of the xynA gene encoding xylanase A of Aspeigillus kawachii. Biosci. Biochem. Biotech., 56:906-912.

Iwashita, K.; Todoroki, K.; Kimura, H.; Shimoi, H. and Ito, K. (1998). Purification and Characterization of extracellular and cell wall bound $\beta$-glucosidases from Aspergillus kawachii. Biosci. Biotechnol. Biochem., 62:1938-1946.

Jarvis, M.C. (1984). Structure and properties of pectin gels in plant cell walls. Plant Cell Environ., 7:153-164.

Jarvis, M.C. and McCann, M.C. (2000). Macromolecular biophysics of the plant cell wall: concepts and methodology. Plant Physiology Biochemistry, 38:1-13.

Junjro, O., Kenichi, O. and Tetsugo, H. (1959). Pectin polygalacturonase of Saccharomyces fragilis. Nôgaku Kenkyû, 47:105-110. 
Kawai, S.; Takahashi, K. and Tamaki, Y. (1977). Production of citron-sake. III. Nippon Jozo Kyokai Zasshi, 72:680-681.

Kaneko, A.; Sudo, S.; Takayasu-Sakamoto, Y.; Tamura, G.; Ishikawa, T. and Oba, T. (1996). Molecular cloning and determination of the nucleotide sequence of a gene encoding an acid-stable $\alpha$-amylase from Aspergillus kawachii. J. Ferment. Bioeng., 81:292-298.

Kennedy, R.B. (1985). Pectin and related carbohydrates for the preparation of polyurethane foams. US Patent 4,520,139.

Kojima, Y.; Sakamoto, T.; Kishida, M.; Sakai, T. and Kawasaki, H. (1999). Acidic conditioninducible polygalacturonase of Aspergillus kawachii. Journal of Molecular Catalysis B: Enzymatic, 6:351-357.

Lee, C.-H. (2001). Korea, the land of soybean fermentation. En: Fermentation Technology in Korea. Lee, C.-H. (Ed.). Korea University Press: Seoul, Korea. pp:70-91.

Lee, T.S.; Chun, M.S. and Oh, K.H. (1984). Effect of kojis on the composition of kochujang. Journal of the Korean Society of Food and Nutrition, 13:238-246.

May, C.D. (1990). Industrial pectins: sources, production and applications. Carbohydrate Polymers 12:79-99.

McCleary, B.V. (1986) Enzymatic modification of plant polysaccharides. International Journal Biol. Macromol. 8:354-349.

McFeeters, R.F.; Hankin, L. and Lacy, G.H. (1992). Pectinolytic and pectolytic microorganisms. In: Compendium of Methods for the Microbiological Examination of Foods. C. Venderzant; D.F. Splittstoesser (Eds.). American Public Health Association: Washington, DC. pp:213-223.

Mikami, S.; Iwano, K.; Shiinoki, S. and Shimada, T. (1987). Purification and some properties of acid-stable $\alpha$-amylases from shochu koji (Aspergillus kawachii). Agric. Bol. Chem., 51:2495-2501.

Mikami, S.; Karita, S.; Iwano, K.; Shiinoki, S. and Shimada, T. (1989). Purification and some properties of hydrolases from shochu koji (Aspergillus kawachii). Nippon Nogeikagaku Kaishi 62:867-874.

Mohnen, D. (1999). Biosyntesis of pectins and galactomannans. In: Comprensive Natrual Products Chemistry. Barton, D.; Nakanishi, K. and Meth-Cohn, O. (Eds.). Elsevier: Amsterdam. pp:497-527.

Morimura, S.; Zhang, W.X.; Ichimura, T.; Kida, Y.; Ibi, Y. and Kida, K. (1999). Genetic engineering of white shochu-koji to achieve higher levels of acid-stable $\alpha$-amylase and 
glucoamylase and other properties when used for shochu making on a laboratory scale. $J$. Inst. Brew. 105:309-314.

Mutter, M. (1997). New rhamnogalacturonan degrading enzymes from Aspergillus aculeatus. PhD Thesis. Wageningen Agricultural University. The Netherlands. pp:1-141.

Nakamura, T.; Hours , R.A. and Sakai, T. (1995). Enzymatic maceration of vegetables with protopectinases. Journal of Food Science, 60:468-472.

Nunokawa, Y.; Shiinoki, S. and Hirotsune, M. (1982). Production of mirin with use of shoshu-koji. II Quality improvement of mirin. Nippon JozoKyokai Zassi, 77:123-125.

Obayashi, A. and Uchi, S. (1999). Manufacture of shochu from sweet potatoes. Jpn. Kokai Tokkyo Koho, 4 pp. JP 11032751.

Omori, T.; Takeshima, N. and Shimoda, M. (1994). Formation of acid-labile $\alpha$-amylase during barley-koji production. J. Ferm. Bioeng., 78:27-30.

Parenicová, L. (2000). Pectinases of Aspergillus niger: a molecular and biochemical characterisation. PhD Thesis. Wageningen Agricultural University. The Netherlands.

Pilnik, W. y Voragen, A.G.J. (1970) Pectic substances and other uronides. En "The bioChemistry of fruits and their products." Vol. 1 pg: 53-87, Editado por Humle, A.C., Academic Press, Londres.

Pilnik, W. and Romboust, F.M. (1979). Utilization of pectic enzymes in food production. In: Food Science and Technology. Chiba, H.; Fujimaki, M.; Iwai, K.; Mitsuda, H. and Morita, Y. (Eds.).7 Amsterdam: Elsevier Scientific Publishing Company. pp: 269-277.

Pilnik, W. and Romboust, F.M. (1981). Pectic enzymes. In: Enzymes an Food Processing. Birch, G.G.; Blakebrough, N.; Parker, K.J. (Eds). London: Appl. Sci. Publishers Ltd. pp 105-128.

Pilnik, W. and Voragen, A.G.J. (1991). The significance of endogenous and exogenous pectic enzymes in fruit and vegetable processing. In: Food Enzymology. Volumen 1. P.F. Fox (Ed.). Elsevier Applied Science: New York, pp 303-336.

Pilnik, W. and Voragen, A.G.J. (1992). Gelling agents (pectins) from plants for the food industry. Advances in Plant Cell Biochemistry and Biotechnology, 1:219-270.

Pilnik, W. and Voragen, A.G.J. (1993). Pectic enzymes in fruit and vegetable juice manufacture. In: Enzymes in Food Processing. pp:363-399.

Pressey, R. (1993). Uronic acid oxidase in orange fruit and other plant tissues. Phytochemistry, 32 :1375-1379. 
Rättö, M and Viikari, L (1996). Pectinases in wood debarking. In: Progress in Biotechnology 14 (Pectins and Pectinases). Voragen, A.G.J. and Visser, J. (Eds.) Elsevier: The Netherlands, pp:979-982.

Renard, C. (1989). Etude des polysaccharides parietaux de la pomme. Extraction at caracterization par des methodes chimiques et enzymatiques. These de Doctorat, Université de Nantes, France.

Ridley, B.L.; O’Neill, M.A. and Mohnen, D. (2001). Pectins: structure, biosynthesis, and oligogalacturonoide-related signaling. Phytochemistry, 57:929-967.

Rolin, C.; Nielsen, B.U. y Glahn, P.-E. (1998). Pectin. In: Polisaccharides. Structural diversity and function versatility. S. Dumitriu (Ed.). Mercel Dekker: New York. pp: 377431.

Rombouts, F.M.; Pilnik, W. (1980). Pectic enzymes. In: Economic Microbiology. Microbial Enzymes and Conversions. Vol. 5. A.H. Rose (Ed.). Academic Press: New York. 227-282.

Sakamoto, S.; Tamura, G.; Ito, K.; Ishikawa, T.; Iwano, K. and Nishiya, N. (1995). Cloning and sequencing of cellulase cDNA from Aspergillus kawachii and its expression in Saccharomyces cerevisiae. Curr. Genet., 27:435-439.

Sakai T, Sakamoto T, Hallert J, Vandamme E.J (1993). Pectin, pectinase, and protopectinase: production, properties, and applications. Adv. Appl. Microbiol. 39:213-294.

Setoguchi, S.; Takamine, K.; Kamesawa, H. and Hamasaki, Y. (1993). Study on sweet potato koji. Kagoshima-ken Kogyo Gijutsu Senta Kenkyu Hokoku, 7:13-19.

Shimamura, K.; Sasaki, T. and Sato, T. (2001). Manufacture of alcoholic beverages using fruit juice and white koji. Jpn. Kokai Tokkyo Koho, 2 pp. JP 2001029061.

Shivakumar, P.D.; Nand, Krishna (1995). Anaerobic degradation of pectin by mixed consortia and optimization of fermentation parameters for higher pectinase activity. Lett. Appl. Microbiol., 20:117-119.

So, M.-H.; Lee, Y.-S.; Han, S.-H. and Noh, W.-S. (1999a). Analysis of major flavor compounds in Takju mash brewed with a modified Nuruk. Han'guk Sikp'um Yongyang Hakhoechi, 12:421-426.

So, M.-H.; Lee, Y.-S. and Noh, W.-S. (1999b). Improvement in the quality of Takju by a modified Nuruk. Han'guk Sikp'um Yongyang Hakhoechi, 12:427-432.

Sudo, S.; Ishikawa, T.; Sato, K. and, Oba, T. (1994). Comparison of acid-stable $\alpha$-amylase production by Aspergillus kawachii in solid-state and submerged cultures. J. Ferm. Bioeng., 77:483-489. 
Schols, H.A. (1995). Structural characterization of pectic hairy regions isolated from apple cell walls. PhD Thesis. Wageningen Agricultural University. The Netherlands. pp:1-155.

Teramoto, Y.; Saigusa, N.; Yoshida, Y.; Ueda, S. and Yoshizawa, K. (1994). Production and characteristics of red rice sake. J. Inst. Brew., 100:3-6.

Toyama H. and N. Toyama, N. (1997). Isolation of acid hyper-producing strains from hiperpolyploids of Aspergillus kawachii. Microbios, 90:23-32.

Van Buren, J.P. (1991). Function of pectin in plant tissue structure and firmness. In: The Chemistry and Technology of Pectin. Walter, R.H. (Ed.).San Diego:Academic Press, Inc. pp: 1-22.

Vlugt-Bergmans, C.J.B.; Meeuwsen, P.J.A.; Voragen, A.G.J. and Ooyen, A.J.J. van (2000). Endo-xylogalacturonan hydrolase, a novel pectinolytic enzyme. Applied Enviromental Microbiology, 66:36-41.

Vries, R.P. de (1999). Accesory enzymes from Aspergillus invloved in xylan and pectin degradation. PhD Thesis. Wageningen Agricultural University. The Netherlands.

Voragen, A.G.J. y Pilnik, W. (1988). Pectin-degrading enzymes in fruit and vegetable processing. En Biocatalyisis in Agricultural Biotechnology. Ed. Whitaker, J.R. y Sonnet, P.E. ACS Symp. Series 389. Washington, D.C.: Am. Chem. Soc. pp 93-114.

Voragen, F.; Beldman, G.; and Schols, H. (2001). Chemistry and enzymology of pectins. In: Advanced Dietary Fibre Technology. McCleary, B and Prosky, L. (Eds.). Blackwell Science: Ireland. pp:379-398.

Willats, W.G.T.; Steele-King, C.G.; McCartney, L.; Orfila, C.; Marcus, S.E. and Knox, J.P. (2000). Making and using antibody probes to study plant cell walls. Plant Physiology Biochemistry, 38:27-36.

Wong, D.W.S. (1995). Pectic Enzymes. In: Food Enzymes. Structure and Mechanism. D.W.S. Wong (Ed.). Capman \& Hall: Mexico. pp:212-236.

Yagi, F.; Fan, J.; Tadera, K. and Kobayashi, A. (1986). Purification and characterization of carboxyl proteinase from Aspergillus kawachii. Agric. Biol. Chem., 50:1029-1033.

Yamada, H. (1994). Pectic polysaccharides from chinese herbs: structure and biological activity. Carbohydrate Polymers, 25:269-276.

Zhang, W.; Yang, R. (2001). Application of engineering-strain in preparation of acetic acid beverage with orange juice. Zhongguo Niangzao, (3), 11-15, 22. 


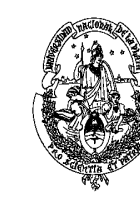

UNLP

\section{$\mathbf{C}^{\text {AprtuLo }} 2$}

Tesis Doctoral

Argentina

\section{Caracterización del sistema pectolítico de Aspergillus kawachii}

Resumen

Se realizó un screening de actividades enzimáticas producidas por A. kawachii en cultivos líquidos conteniendo como fuente de carbono glucosa o materiales vegetales complejos (MVC), triptona y sales a $\mathrm{pH}$ inicial 4.0. El screening se realizó empleando sustratos poliméricos solubles, glicósidos cromogénicos y protopectina. Los resultados mostraron que A. kawachii posee un sistema pectolítico constituido fundamentalmente por poligalacturonasas (PGasas), pectin-liasa (PeL), pectin-metilesterasa (PME) y un conjunto de glicosidasas, pero carece, o al menos no pudo detectarse por los métodos empleados, de una actividad enzimática que degrade ramnogalacturonano en forma endo. Las PGasas se expresan en forma constitutiva ya que se encontró una actividad significativa en el medio con glucosa; no obstante su actividad se incrementó notoriamente en cultivos con MVC que contienen pectina. En el medio glucosa también se determinó actividad protopectinasa (PPasa) la cual se atribuyó a la acción de las PGasas. Otras pectinasas como PME, PeL y un conjunto de glicosidasas que actúan sobre sustratos cromogénicos no se expresaron en el medio con glucosa y fueron inducidas en los medios con MVC. Los preparados crudos de los medios de cultivo mostraron actividad PGasa y PPasa en el rango de $\mathrm{pH}$ 1.7-5.5. La determinación de los perfiles de actividad/pH para ambas actividades antes y después de filtrar el medio glucosa por filtros de fibra de vidrio, demostró que en este medio se producen al menos dos tipos de PGasas/PPasas que se diferencian en la propiedad de adsorberse al filtro La actividad a $\mathrm{pH}$ ácido $(\mathrm{pH} \leq 3.5)$, que no se adsorbe, es estable a $50{ }^{\circ} \mathrm{C}$ y es capaz de extraer sustancias pécticas de alto peso molecular de cáscaras de limón. Este es el primer reporte de estas actividades en A. kawachii.

\subsection{Introducción}

La degradación de la pared celular vegetal es llevada a cabo por una gran variedad de enzimas, cuya acción genera una amplia gama de productos intermedios, oligosacáridos y unidades monoméricas, que finalmente sirven de nutrientes o van a intervenir en la regulación de algún proceso físiológico en particular. La síntesis de estas enzimas en general está regulada por mecanismos de inducción/represión que actúan a nivel de la transcripción y/o translación. Los inductores suelen ser los productos de degradación del polímero (generalmente monómeros o dímeros), mientras que la represión es un fenómeno más 
complejo de definir. En general este proceso ocurre en presencia de altas concentraciones de glucosa u otros azúcares rápidamente metabolizables, que promueven una alta velocidad de crecimiento microbiano. Este fenómeno es conocido como represión catabólica. Para determinar el efecto inductivo o represivo de un determinado nutriente, componente del medio o factor ambiental, se mide el aumento o disminución de la proteína enzimática o del ARNm sintetizado, en comparación con un nivel de referencia. Uno de los sistemas más estudiados en hongos filamentosos (A. niger) es la expresión de los genes involucrados en la degradación de la (hemi)celulosa [de Vries, 2003]. El complejo xilanolítico es inducible por xilosa y está mediado por el activador transcripcional XLNR. Este activador regula además la expresión de otras enzimas que degradan la pared celular tales como endoglucanasas, celobiohidrolasas, feruil-esterasas y otras [van Peij et al., 1998; Gielkens et al., 1999]. Altas concentraciones de xilosa reprimen la inducción mediada por XLNR, efecto que parece involucrar a proteínas represoras del tipo CreA (carbon catabolite repressor protein) [de Vries et al., 1999]. El fenómeno de inducción se ha observado también en arabinasas, en cuyo caso los inductores son arabinosa y arabitol [Flipphi et al., 1994].

Los mecanismos moleculares que controlan la síntesis de las pectinasas microbianas son aún poco conocidos. El sistema genético mejor estudiado es el de la bacteria Erwinia carotovora. En este caso, los genes involucrados en el catabolismo de la pectina y la producción de pectinasas son inducidos por intermediarios del catabolismo del ácido galacturónico (e.j. 2-ceto-3-deoxi-gluconato), mientras que el control negativo de la expresión lo ejerce un complejo sistema de represión que involucra proteínas regulatorias, AMPc, etc. La síntesis de las pectinasas es influenciada además por factores ambientales tales como la osmolaridad del medio, temperatura, disponibilidad de nitrógeno u oxígeno, limitación de hierro y la presencia de agentes que dañan el ADN [Hugouvieux-Cotte-Pattat et al., 1996]. En hongos filamentosos la tendencia general observada en varias especies de Aspergillus (A. niger, A. tubigiensis, A. flavus, A. aculeatus, etc.) y en fitopatógenos, es que la síntesis de las enzimas pectolíticas como PGasas, PME, PeL o PecL, es inducida por pectina, APG y AGA y reprimida por glucosa [de Vries et al., 1999]. En algunos casos la inducción es promovida por azúcares como $\alpha$-L-ramnosa y $\alpha$-L-arabinosa [Hugouvieux-Cotte-Pattat et al., 1996]. En forma similar a lo descripto en otros sistemas genéticos, se ha demostrado la intervención de proteínas CreA e incluso AMPc en los fenómenos de represión de las pectinasas [Cooper and Wood, 1973; Ruijter and Visser, 1997]. Los factores ambientales también modulan la síntesis de las enzimas fúngicas y es interesante mencionar que la expresión de ciertos genes, que codifican pectinasas u otras enzimas hidrolíticas, está controlada por el $\mathrm{pH}$ del medio 
[Cavalitto et al., 1996; Trejo-Aguilar et al., 1996; Wubben et al., 2000]. La mayor parte de los estudios de inducción/represión de pectinasas en hongos se refieren a las enzimas que actúan sobre el HG y a las denominadas enzimas accesorias. Poco se conoce de la regulación de la síntesis de enzimas que degradan el RG y otros polímeros como RGII y XG.

Tal como se comentó en el Capítulo introductorio, el sistema pectolítico de A. kawachii ha sido poco estudiado. Por tal motivo, en la primera parte de este trabajo se realizó un screening de actividades utilizando para esto muestras de diferentes medios de cultivo. Con relación a estos estudios es apropiado hacer algunos comentarios previos. La elección de las condiciones experimentales para estudiar la síntesis de enzimas en hongos filamentosos es en parte dificultosa. El sistema continuo, que permite definir claramente las condiciones de crecimiento del microorganismo, es difícil de aplicar en este caso. Esto es debido al crecimiento micelial, que por sus características dificulta la operación de los biorreactores tradicionales e introduce heterogeneidad en el cultivo. Además, en ciertos casos como el crecimiento en pellets, la influencia de restricciones difusionales en el control metabólico no es fácil de establecer. Los hongos filamentosos se adaptan muy bien a los cultivos sólidos (sin agua libre) y es habitual que se realicen estudios comparativos entre cultivos sumergidos (batch o batch alimentado) y cultivos sólidos respecto de la producción de enzimas y productos metabólicos [Solis-Pereira et al., 1993; Maldonado and de Saad, 1998]. La dificultad de controlar ciertas variables en las fermentaciones sólidas $(\mathrm{pH}$, tensión de oxígeno, temperatura) genera también incertidumbre a la hora de comparar los resultados de estas fermentaciones con los obtenidos en los cultivos sumergidos. Teniendo en cuenta que el objetivo del trabajo no fue optimizar la producción de una determinada enzima sino identificar las actividades más relevantes, se eligió el cultivo sumergido frente al cultivo sólido por razones de practicidad, ya que este hongo crece fácilmente en este tipo de cultivo. Como referencia se empleó un medio conteniendo glucosa, triptona y sales, el cual fue empleado para la producción de amilasas con la cepa de A. kawachii IFO 4308, que es la empleada en este trabajo [Sudo et al., 1993]. Los otros medios ensayados incluyeron el uso de materiales vegetales complejos (MVC) en reemplazo de la glucosa (ver Tabla 2.1). Dichos materiales contienen polímeros de la pared celular vegetal, entre estos pectina, que podrían actuar como inductores de la actividad enzimática. En este sentido, existen referencias del empleo de MVC en la producción de pectinasas. Al respecto, Bonnin et al. [2001] realizaron cultivos en medio líquido de A. niger I-1472 y Pycnoporus cinnabarinus MUCL39533 empleando remolacha azucarera (es comparable al medio PR, Tabla 2.1). En este medio, A. niger produjo un amplio espectro de actividades enzimáticas incluyendo RGasa, PGasa, 
arabinasa, galactanasa, xilanasa y diversas glicosidasas. Hellín et al. [2001] utilizaron cáscara de limón como única fuente de carbono para el crecimiento y producción de PGasa en cultivos líquidos de Rhyzopus nigricans. Couri et al. [2000] utilizaron cáscara de mango como materia prima para el crecimiento en medio sólido de A. niger para la producción de PGasas. Hara et al. [1982] emplearon cáscara deshidratada de mandarina para la producción de PGasas por A. niger por fermentación en medio líquido y encontraron que la efectividad de la cáscara de mandarina para la producción de PGasa fue similar a la obtenida en medios suplementados con pectina. El contenido de azúcares ácidos y neutros de estos materiales (excepto el de mango que no fue reportado) es comparable al de los materiales empleados en este estudio. Por otra parte, no se encontraron referencias sobre el uso de pomaza de tejocote o receptáculo de girasol en la producción de enzimas pécticas, ya sea en fermentación sólida como líquida. Estos materiales poseen altos contenidos en sustancias pécticas [Pedroza-Islas et al., 1995; Sabir et al., 1976], por lo que fueron seleccionados como posibles inductores de pectinasas.

\subsection{Materiales y métodos}

\subsubsection{Reactivos, enzimas y soluciones}

Pectina cítrica (85\% de AGA anhidro, grado de metoxilación GM, $53 \%$ ), ácido poligalacturónico (APG; sal sódica, 90 \% de AGA anhidro), xilano de madera de haya, AG de madera de alerce, $p$-nitrofenil- $\beta$-D-glucopiranósido (pnp-Glu), o-nitrofenil- $\beta$-Dgalactopiranósido (ONPG), $p$-nitrofenil- $\alpha$-L-ramnopiranósido (pnp-Ram), p-nitrofenil- $\alpha$-Larabinopiranósido (pnp-Ara), $p$-nitrofenil- $\alpha$-L-xilopiranósido (pnp-Xil), $p$-nitrofenil- $\beta$-Dfucopiranósido (pnp-Fuc), hemoglobina, pepstatina, 3-fenil-fenol ( $m$-hidroxidifenilo); carboximetilcelulosa (CMC) y AGA fueron obtenidos de Sigma. Agar papa-dextrosa (APD) fue de Merck y la triptona de Difco. El RG de soja fue obtenido de Megazyme (Irlanda).

El producto enzimático Olivex fue obtenido de Novozyme (Dinamarca). Este producto está recomendado para liquefacción enzimática de pulpa de aceituna con el objeto de incrementar la extracción de aceite de oliva. Se lo empleó como control de diversas actividades enzimáticas incluido el test en gel para detectar actividad frente a RG. Para su uso, el producto se diluyó 1:50 en buffer AcONa $50 \mathrm{mM}$, pH 4.5 y se pasó por una columna PD-10 (Pharmacia, Biotech) equilibrada con el mismo buffer. Como fuentes de PME y de PeL fúngicas se emplearon los preparados FP Super ${ }^{\circledR}$ (Gist Brocades) y Pectolyase (Sigma Aldrich), respectivamente. 
La composición del buffer citrato-fosfato $(\mathrm{BCP})$ fue la siguiente: ácido cítrico $50 \mathrm{mM}$, fosfato disódico $25 \mathrm{mM}$, ajustado a $\mathrm{pH} 5.5$ con $\mathrm{NaOH}$. La composición del buffer AcONa fue: $50 \mathrm{mM}$ ácido acético ajustado a pH 5.5 con $\mathrm{NaOH}$. Cuando fue requerido, los buffers se diluyeron y/o su pH se modificó al valor deseado mediante el agregado de HCl. La dilución del buffer se expresa con una fracción (e.j. BCP $1 \frac{1}{2}$ indica buffer BCP diluido a la mitad).

\subsubsection{Materiales vegetales}

Pomaza de limón (PL). Se define pomaza al producto obtenido de diferentes residuos agroindustriales los cuales han sido escaldados, lavados y secados cuidadosamente para ser empleados en la extracción de pectina. Se utilizó pomaza de limón (Citrus limon Burm) proveniente de la empresa Citrinor (Tucumán, Argentina). El material fue seleccionado, tomándose únicamente las cáscaras y descartando las semillas. La pomaza libre de semillas fue triturada mecánicamente con la ayuda de un procesador de alimentos.

Pomaza de mango (PM). Se utilizaron mangos (Mangifera indica L.) provenientes de Brasil comprados en el mercado local. Las frutas fueron lavadas y seleccionadas. Las cáscaras fueron retiradas cuidadosamente con la ayuda de un cuchillo, se les quitó la pulpa remanente y se escaldaron durante 5 min en un cocedor a vapor. Luego se lavaron con agua destilada hasta eliminar los azúcares solubles (reacción negativa de fenol-sulfúrico) y se deshidrataron a $60{ }^{\circ} \mathrm{C}$ hasta peso constante, finalmente se las trituró en un procesador de alimentos.

Pulpa de remolacha (PR). Se utilizó pulpa de remolacha azucarera (Beta vulgaris L.) deshidratada provista por una empresa azucarera Chilena.

Pulpa de tejocote (PT). Se usó pulpa de tejocote (Crataegus mexicana) deshidratada grado industrial de Alimenta SA (Michoacán, México).

Receptáculo de girasol (RGL). Se usaron receptáculos de girasol (Helianthus annuus L., híbrido Contflor 15, Zeneca) libres de semillas, provenientes de un campo experimental de la Facultad de Ciencias Agronómicas de la Universidad Nacional de La Plata, Argentina. El material fue cortado en trozos de $2 \mathrm{~cm}$, se deshidrató a $60{ }^{\circ} \mathrm{C}$ hasta peso constante y se trituró en un procesador de alimentos.

En todos los casos, el material triturado se tamizó, seleccionando el sólido que pasó tamiz 80 y retenido en tamiz 100.

En la Tabla 2.1 se muestra la composición de los MVC descriptos (la metodología analítica se detalla en la Sección 2.2.5.1.). El contenido total de azúcares (suma de los azúcares individuales) con excepción de RGL (39\%) resultó en promedio 57 \% (en base húmeda). La suma AGA + Glu representó el 70 \% de los azúcares totales, lo cual es lógico ya 
que estos son los residuos predominantes en los polímeros de la pared celular vegetal. Ara y Gal representan los residuos predominantes en las cadenas laterales de las pectinas mientras que Xil y Man lo son del xiloglucano y/o hemicelulosa. El RGL tiene un alto contenido de Glu y Xil y baja proporción de AGA y Ara en comparación con los otros materiales, evidenciando el predominio de los componentes celulósicos y hemicelulósicos sobre la pectina. Es interesante resaltar el alto contenido de Ara en PR que coincide con lo reportado en bibliografía [Bonnin et al., 2000]. El contenido de proteínas de los materiales varió entre el 3 y $7 \%$. La relación $\mathrm{C} / \mathrm{N}$ es $>$ de 20 (excepto $\mathrm{RGL}=15$ ). Desde el punto de vista de la provisión de nutrientes para el crecimiento fúngico, estos materiales presentan un déficit de $\mathrm{N}$, ya que una relación $\mathrm{C} / \mathrm{N}$ óptima para el crecimiento microbiano se estima en $\sim 10\left(\mathrm{Y}_{\mathrm{X} / \mathrm{S}}=0.5\right.$ g biomasa/g glucosa con un contenido de $\mathrm{N}$ en biomasa del 8-10 \%). En la Tabla también se indica la capacidad de hinchamiento como parámetro de la capacidad de hidratación de cada material [Kunzek et al., 1999]. Los valores son muy parecidos, en el caso del RGL este dato no se cuantificó debido a que su baja densidad impide que sedimente, condición que es requerida por el método.

Tabla 2.1. Composición química de diversos materiales vegetales.

\begin{tabular}{lccccc}
\hline \multicolumn{1}{c}{ Descripción } & $\begin{array}{c}\text { Pomaza de } \\
\text { limón (PL) }\end{array}$ & $\begin{array}{c}\text { Pomaza de } \\
\text { mango (PM) }\end{array}$ & $\begin{array}{c}\text { Pulpa de } \\
\text { remolacha } \\
\text { (PR) }\end{array}$ & $\begin{array}{c}\text { Pulpa de } \\
\text { tejocote (PT) }\end{array}$ & $\begin{array}{c}\text { Receptáculo } \\
\text { de girasol } \\
\text { (RGL) }\end{array}$ \\
\hline Azúcares (mg/g)* & & & & & 5 \\
Ramnosa (Ram) & 6 & 5 & 7 & 4 & 0.5 \\
Fucosa (Fuc) & 3 & 2 & 1 & 2 & 16 \\
Arabinosa (Ara) & 74 & 60 & 159 & 86 & 49 \\
Xilosa (Xil) & 25 & 17 & 13 & 27 & 28 \\
Manosa (Man) & 22 & 27 & 12 & 17 & 274 \\
Galactosa (Gal) & 50 & 44 & 44 & 174 & 111 \\
Glucosa (Glu) & 180 & 165 & 170 & 193 & 6.7 \\
A. galacturónico (AGA) & 296 & 216 & 189 & 3.1 & 7.1 \\
Proteínas : N $\times \mathbf{6 . 2 5}(\%) *$ & 6.7 & 4.2 & 7.1 & 5.0 & ND \\
Humedad (\%) & 8.2 & 8.3 & 6.6 & 10.6 & 15 \\
CH (ml/g)** & 12.5 & 8.1 & 11.2 & 43 & \\
Relación C/N & 24 & 32 & 21 & & 24 \\
\hline
\end{tabular}

* Base húmeda. ** CH capacidad de hinchamiento (relacionada con el contenido de sustancias pécticas). 


\subsubsection{Microorganismo, medio y condiciones de cultivo}

Se utilizó la cepa de Aspergillus kawachii IFO 4308, proporcionada por el Profesor Takuo Sakai de la Universidad Prefectural de Osaka, Japón. La cepa se propagó a $30^{\circ} \mathrm{C}$ en tubos con medio APD y se la mantuvo a $4{ }^{\circ} \mathrm{C}$ bajo capa de vaselina (cultivo stock). Para la producción de conidios se tomó muestra del cultivo stock y se sembró medio APD (30 ml de medio en erlenmeyers de $125 \mathrm{ml}$ ). Después de 7 días de incubación a $30{ }^{\circ} \mathrm{C}$, los conidios se resuspendieron con $20 \mathrm{ml}$ de solución estéril de Tween 80 al $0.01 \%$ p/v. El recuento de conidios se efectuó en cámara de Neubauer. La concentración típica en esta suspensión fue del orden de $10^{8}$ conidios $/ \mathrm{ml}$. Cuando fue necesario, los medios sólidos esporulados se mantuvieron refrigerados, usándose dentro del mes de preparación.

Para la fermentación líquida se utilizaron matraces de $1000 \mathrm{ml}$ con $100 \mathrm{ml}$ de medio de cultivo, cuya composición fue similar al utilizado para la producción de amilasas con esta misma cepa [Sudo et al., 1993]. La composición de dicho medio fue la siguiente (g/l): fuente de carbono (glucosa o MVC) 10, triptona 5.0, $\mathrm{K}_{2} \mathrm{HPO}_{4} 1.0, \mathrm{KCl} 0.5, \mathrm{MgSO}_{4} \cdot 7 \mathrm{H}_{2} \mathrm{O} 0.5$, $\mathrm{FeSO}_{4} \cdot 6 \mathrm{H}_{2} \mathrm{O} 0.01$. El pH fue ajustado a 4.0 con solución de $\mathrm{H}_{3} \mathrm{PO}_{4} 1 \mathrm{~N}$. Los fosfatos y las fuente de carbono fueron esterilizados por separado. Las distintas fracciones se esterilizaron en autoclave $15 \mathrm{~min}$ a $121{ }^{\circ} \mathrm{C}$. Luego de reconstituidos, los medios se inocularon con la suspensión de conidios para dar una concentración de $10^{6}$ conidios $/ \mathrm{ml}$ de medio. Los frascos se incubaron a $30{ }^{\circ} \mathrm{C}$ en shaker a $200 \mathrm{rpm}$ (New Brunswick Scientific, Edison, NJ, USA).

\subsubsection{Procesamiento de los cultivos y obtención de las muestras para el screening de actividades enzimáticas}

Para la toma de muestra se utilizó el contenido total del erlenmeyer. Luego de determinar el volumen del medio, se midió el pH del mismo y se lo ajustó a 5.0 con $\mathrm{HCl}$ o con $\mathrm{NaOH} 1 \mathrm{~N}$ para estandarizar el proceso de filtración en lo que concierne al $\mathrm{pH}$ de las muestras. Ensayos preliminares mostraron que existe adsorción de proteínas a los filtros y este fenómeno depende del $\mathrm{pH}$ del medio (este tema será tratado con mayor detalle en el capítulo 5). Luego se procedió a la separación primaria de la fase sólida del medio de fermentación (micelio y la fracción insoluble remanente de los MVC) mediante filtración a través de filtros de papel de celulosa (Whatman 40) usando un soporte de polipropileno $(\phi=90 \mathrm{~mm})$. La fase sólida obtenida se lavó con agua destilada y se secó a $60{ }^{\circ} \mathrm{C}$ hasta peso constante. La muestra seca se trituró en mortero y tamizó para su posterior análisis. El filtrado a pH 5.0 obtenido en la separación primaria se usó inmediatamente o bien se congeló a $-20{ }^{\circ} \mathrm{C}$ en botellas de plástico 
de $100 \mathrm{ml}$. Cuando fue necesario, las muestras se descongelaron rápidamente en un baño de agua a $37{ }^{\circ} \mathrm{C}$ con agitación a los efectos de acelerar el proceso de modo de evitar la desnaturalización de las proteínas presentes. En ambos casos, el filtrado primario se clarificó mediante una segunda filtración usando filtros de fibra de vidrio $(\phi=47 \mathrm{~mm}$; Type G15 glass pre-filters, nominal pore size: $0.5 \mu \mathrm{m}$, OSMONICS) y un soporte de filtros de polisulfona (MSI). La muestra clarificada se dializó toda la noche a $4{ }^{\circ} \mathrm{C}$ frente a $\mathrm{AcONa}(1 / 2), \mathrm{pH} 5.0$, se la transfirió a recipientes de vidrio y liofilizó. Los liofilizados se conservaron refrigerados. Para medir la actividad enzimática, el liofilizado se resuspendió con agua deionizada a una concentración $10 \times$ respecto a la original y se centrifugó 1 min en microcentrífuga $(10.000 \times$ g) para eliminar cualquier resto de material insoluble. La solución se conservó a $5{ }^{\circ} \mathrm{C}$ por un período no mayor de 3 días.

\subsubsection{Determinaciones analíticas}

\subsubsection{Análisis físico-químicos}

El contenido de glucosamina de los sólidos del medio de cultivo se determinó por el método propuesto por Nandi [1978]. En el filtrado se determinaron: a) glucosa por el método enzimático glucosa oxidasa-peroxidasa (Glicemia, Wiener Argentina), b) carbohidratos totales por la técnica del fenol-sulfúrico [Dubois et al., 1956], c) azúcares reductores con el reactivo DNS [Miller, 1959] y d) AGA con m-hidroxidifenilo [Blumenkrantz and AsboeHansen, 1973]. Para el análisis de azúcares en los MVC, las muestras se hidrolizaron de acuerdo con el método propuesto por Seaman et al. [1954], el cual consiste en un tratamiento de una hora a $30{ }^{\circ} \mathrm{C}$ con $\mathrm{H}_{2} \mathrm{SO}_{4} 72 \%(\mathrm{p} / \mathrm{p})$, seguido de una hidrólisis con $\mathrm{H}_{2} \mathrm{SO}_{4} 1 \mathrm{M}$ durante 3 h a $100{ }^{\circ} \mathrm{C}$. El contenido de AGA en los hidrolizados fue determinado por el método automatizado del $m$-hidroxidifenilo en un espectrofotómetro continuo (Alliance Instruments, Méry/Oise, Francia). El contenido de azúcares neutros individuales fue analizado por cromatografía gaseosa en un equipo Shimatzu (Kyoto, Japan), empleando una columna capilar de $30 \mathrm{~m} \times 0.25 \mathrm{~mm}$, rellena con DB225 de $0.15 \mu \mathrm{m}$ (J \& W. Scientific, Folsom, USA) a $215^{\circ} \mathrm{C}$ e $\mathrm{H}_{2}$ como gas portador. La derivatización de los azúcares neutros a alditoles se realizó por el método propuesto por Englyst and Cummings [1988] usando inositol como estándar interno. El contenido de nitrógeno se determinó por el método de Micro-Kjeldahl, de acuerdo a la técnica descripta por Pilosof y Bartholomai [2000]. Proteína totales se determinaron por el método de Lowry empleando albúmina bovina como patrón [Lowry et 
al., 1959]. La capacidad de hinchamiento fue determinada de acuerdo al método descripto por Baquero y Bermúdez [1998].

\subsubsection{Determinación de actividades enzimáticas}

Actividad sobre glicósidos: se determinó por la liberación de cromógenos a partir de sustratos sintéticos. A tal fin, se incubaron $200 \mu$ de solución de sustrato ( $1 \mathrm{mM}$ de pnp- $\mathrm{u}$ onp-glicósido en $\mathrm{BCP} 1 / 2, \mathrm{pH} 4.5)$ con $10 \mu \mathrm{l}$ de muestra enzimática durante 30 - $60 \mathrm{~min}$, deteniendo la reacción mediante el agregado de $400 \mu \mathrm{l}$ de $\mathrm{Na}_{2} \mathrm{CO}_{3} 0.4 \mathrm{M}$. El o-nitrofenol o $p$ nitrofenol liberados se evaluaron a $405 \mathrm{~nm}\left(\varepsilon=4500 \mathrm{M}^{-1} \mathrm{~cm}^{-1}\right)$ y a $420 \mathrm{~nm}\left(\varepsilon=18500 \mathrm{M}^{-1}\right.$ $\mathrm{cm}^{-1}$ ), respectivamente.

Actividad sobre sustratos poliméricos (APG, AG, CMC, RG y xilano,): se determinó midiendo el incremento de poder reductor. A tal fin, se incubaron $200 / 1500 \mu 1$ de sustrato $(0.5$ $\%$ de polímero en $\mathrm{BCP} 1 / 2$ ), $\mathrm{pH} 2.0$ o $\mathrm{pH} 5.0$, con 10/50 $\mu$ l de muestra enzimática durante 3060 min. Transcurrido el tiempo seleccionado, las muestras se enfriaron inmediatamente en hielo y la concentración de azúcares reductores en las mismas se determinó por SomogyiNelson [Herber et al., 1971] empleando diferentes patrones según el sustrato empleado. Algunos sustratos, como el xilano o el APG a $\mathrm{pH}<3.0$ presentan una fracción insoluble, la cual no fue removida para los ensayos de actividad. Con los sustratos RG y AG, además de medidas a tiempos cortos, se hicieron incubaciones prolongadas (12 h) para evaluar la degradación del sustrato.

Actividad liasa: se determinó espectrofotométricamente a $235 \mathrm{~nm}$ [Albersheim, 1966]. Como sustratos se emplearon pectina (GM $53 \%$ ), APG o RG al 0.5\% en BCP 0.1 M, pH 5.2. Para la determinación se incubó $1.5 \mathrm{ml}$ de solución de sustrato con $25 \mu \mathrm{l}$ de enzima y la variación de absorbancia se registró continuamente durante 5-15 min en un equipo Beckman DU 640. La actividad se calculó convirtiendo el valor de la pendiente inicial (suministrada por el equipo en unidades de absorbancia) a concentración de productos insaturados $\left(\varepsilon=5500 \mathrm{M}^{-1}\right.$ $\left.\mathrm{cm}^{-1}\right)$.

Actividad pectin-metilesterasa (PME): se determinó por cambio de color de un indicador de $\mathrm{pH}$ durante el curso de la reacción. La medida espectrofotométrica se efectuó a $614 \mathrm{~nm}$ usando solución al $0.5 \%$ de pectina en agua ( $\mathrm{pH}$ 5.1) como sustrato y verde de bromocresol como indicador [Villariño et al., 1993]. La confirmación de la actividad PME se realizó midiendo el metanol liberado de una solución de pectina al $0.5 \%$ en BCP $1 / 2$ por el método de Klavons and Bennet [1986]. 
Actividad sobre protopectina (protopectinasa, PPasa): se determinó por cuantificación de la pectina solubilizada a partir de protopectina de limón [Cavalitto et al. 1997]. En un tubo de ensayo se colocaron $20 \mathrm{mg}$ de protopectina y $950 \mu \mathrm{l}$ de BCP 1/2. Luego de $15 \mathrm{~min}$ se adicionaron $50 \mu \mathrm{l}$ de muestra y se incubó bajo agitación durante 30-60 min. Al tiempo prefijado, el contenido total del tubo se filtró a través de minifiltros de papel (Whatman \# 1), recolectando el filtrado en tubos de vidrio refrigerados. La cantidad de pectina solubilizada se determinó en el filtrado midiendo el contenido de AGA por el método del $m$-hidroxidifenilo. Para ensayos de rutina, la protopectina empleada fue la M1, cuya preparación y composición se describen en el capítulo 4.

Actividad proteolítica: se determinó con hemoglobina desnaturalizada como sustrato, a pH 3.0 (ajustado con KOH) de acuerdo al método propuesto por Lenney [1975].

Definición de actividad enzimática: las unidades de actividad enzimática se refieren a medidas de velocidad inicial. La unidad corresponde a la cantidad de enzima que genera un $\mu \mathrm{mol}$ de producto por min en las condiciones de reacción establecidas. En algunos casos, como en la determinación espectrofotométrica de PME, la actividad se define como un incremento de absorbancia $(\Delta 614 / \mathrm{min})$ y para la actividad proteolítica la unidad corresponde a la cantidad de enzima que genera una absorbancia equivalente a $1 \mu \mathrm{g}$ de tirosina/min. Todas las actividades se midieron a $37^{\circ} \mathrm{C}$.

\subsubsection{Test de RGasa en gel}

La presencia de actividad RGasa se evaluó mediante un test cualitativo usando geles de agarosa con RG [Contreras-Esquivel and Voget, 2001]. A tal fin, se preparó una mezcla de agarosa y de RG (1\% y $0.25 \%$ p/v, concentración final) en buffer AcONa 50 mM, pH 4.5 . Luego de calentar brevemente la mezcla para fundir la agarosa, se colocaron $10 \mathrm{ml}$ de la misma en placas de Petri. Una vez formado el gel, se hicieron celdillas en las cuales se agregó $10 \mu \mathrm{l}$ de muestra enzimática. Las placas se incubaron a $37^{\circ} \mathrm{C}$ durante $6 \mathrm{~h}$, luego de lo cual se cubrieron con una solución de rojo rutenio al $0.05 \%(\mathrm{p} / \mathrm{v})$ en agua y se agitaron moderadamente durante $10 \mathrm{~min}$. La solución remanente se eliminó y el gel se lavó con agua destilada. La presencia de halos incoloros en contraste con un fondo rojo, se empleó como indicativo de la hidrólisis de RG. La actividad RGasa fue evaluada también sobre SDS-PAGE con muestras no tratadas con $\beta$-mercaptoetanol. Los geles conteniendo $0.25 \%(\mathrm{p} / \mathrm{v})$ de RG se prepararon de acuerdo a Smith [1984]. 


\subsubsection{Análisis de los productos de hidrólisis de RG y AG por cromatografía de tamiz molecular}

La degradación enzimática de RG y AG fue analizada por cromatografía de tamiz molecular empleando una columna Sephacryl S-100 (XK 16/70, $100 \mathrm{ml}$ de gel) equilibrada con AcONa 50 mM, pH 3.5 conteniendo $\mathrm{NaCl} 0.15$ M. La columna se calibró con azul dextrano y glucosa como marcadores. El volumen de muestra fue $500 \mu 1$, el caudal $30 \mathrm{ml} / \mathrm{h}$ y el volumen de cada fracción recolectada de $2 \mathrm{ml}$. La presencia de carbohidratos totales en las fracciones recolectadas se realizó por el método del fenol-sulfúrico.

\subsubsection{Adsorción de enzimas a filtros de fibra de vidrio}

Para evaluar la adsorción de enzimas a filtros se utilizó un cultivo con glucosa de 30-40 h. El contenido total de un frasco se filtró a través de tela muselina (cheese cloth) para remover el micelio y el líquido resultante se centrifugó a $5.000 \times g$, $20 \mathrm{~min}$, en botellas plásticas para eliminar insolubles (medio centrifugado, $\mathrm{MC}$ ). $\mathrm{El} \mathrm{MC}$ se ajustó a $\mathrm{pH} 3.0$ con $\mathrm{HCl} 1 \mathrm{~N}$ y se filtró a través del filtro de fibra de vidrio, a temperatura ambiente. Luego de la operación se determinó el perfil actividad/pH para PGasa y PPasa en MC y en el filtrado (permeado) obtenido.

\subsubsection{Ensayos de estabilidad térmica}

Para los ensayos de estabilidad térmica se utilizó el permeado obtenido de la filtración por el filtro de fibra de vidrio, dializado a $5{ }^{\circ} \mathrm{C}$ frente a $\mathrm{BCP}, \mathrm{pH}$ 3.0. La concentración de proteínas en el dializado fue de $\sim 0.3 \mathrm{~g} / \mathrm{l}$. Para evitar el efecto desnaturalizante de la actividad proteolítica durante la incubación, el dializado se incubó 30 min a $37{ }^{\circ} \mathrm{C}$ con pepstatina (10 $\mu \mathrm{g} / \mathrm{ml}$ ). Luego del tratamiento, no se detectó actividad proteolítica. El dializado libre de actividad proteolítica se incubó en tubos con rosca a distintas temperaturas. A tiempos prefijados se tomaron muestras de los tubos, se enfriaron en hielo y se evaluó la actividad enzimática (PPasa) residual.

\subsubsection{Extracción enzimática de pectina}

La extracción de pectina se efectuó empleando limones frescos como materia prima. Los limones se cortaron en mitades y se les extrajo el jugo. La cáscara obtenida se cortó en pequeños trozos que se escaldaron con agua a ebullición en relación 1:2 (peso cáscara: volumen de agua). La mezcla se mantuvo 15 min en esta condición, tiempo suficiente para inactivar las enzimas endógenas [Royo-Iranzo et al., 1975]. Luego, las cáscaras se filtraron 
por tela de nylon, se prensaron para eliminar el líquido residual y se trituraron en un procesador de alimentos para obtener partículas de 2-4 $\mathrm{mm}$. La extracción de pectina se efectuó en erlenmeyers de $125 \mathrm{ml}$ conteniendo $15 \mathrm{~g}$ de la cáscara recientemente procesada, 30 $\mathrm{ml}$ de agua o $30 \mathrm{ml}$ de $\mathrm{BCP}$ ( $\mathrm{pH} 3.0$ ) diluido 1:3 con agua (blancos) o $30 \mathrm{ml}$ de dializado $\mathrm{pH}$ 3.0 diluido 1:3 con agua destilada. El pH de las suspensiones de cáscara fue 3.5. Los erlenmeyers se incubaron a $50{ }^{\circ} \mathrm{C}$ durante $2 \mathrm{~h}$ a $100 \mathrm{rpm}$, separándose los sólidos mediante filtración por papel (Whatman \# 40). La pectina extraída se precipitó mezclando $3 \mathrm{ml}$ del filtrado con $6 \mathrm{ml}$ de etanol frío en tubos cónicos graduados. Para una mejor visualización de la precipitación se agregó a cada tubo $20 \mu 1$ de una solución de rojo rutenio ( $0.02 \%$ p/v en agua) y se centrifugó 10 min a $1200 \times g$ en frío.

\subsection{Resultados}

\subsubsection{Crecimiento de A. kawachii en medios con glucosa y pomaza de limón}

En la Figura 2.1 se muestra la evolución de los cultivos con glucosa y PL y en la Tabla 2.2 se presentan parámetros de crecimiento, evaluados a las 30 y $40 \mathrm{~h}$ de desarrollo en los diferentes medios empleados. En el medio con glucosa el crecimiento celular es seguido por una marcada acidificación del medio, atribuible a la formación de ácidos orgánicos, en particular ácido cítrico [Toyama and Toyama, 1997]. El pH alcanza un valor mínimo de 2.52.7 a las $30 \mathrm{~h}$ de cultivo, momento en el cual se obtiene la máxima concentración celular en coincidencia con el agotamiento de la glucosa. A mayores tiempos de cultivo, la concentración de biomasa tiende a decrecer, probablemente por autólisis, y el pH del medio aumenta. El crecimiento fúngico fue en la forma de pellets que alcanzaron un tamaño de 2.0-3.0 mm. La biomasa máxima obtenida fue $8.5 \mathrm{~g} / 1$ para una concentración inicial de glucosa de $11.5 \mathrm{~g} / 1$, lo cual da un rendimiento celular de $0.74 \mathrm{~g}$ biomasa/g glucosa. Este valor es muy superior al observado en medios con glucosa y amonio ( $\mathrm{Yx} / \mathrm{s} \sim 0.5 \mathrm{~g} / \mathrm{g}$ para una biomasa estándar y formación de producto despreciable), debido a la presencia de una fuente de nitrógeno orgánica, como la triptona, que también aporta carbono para el crecimiento.

En los medios de cultivo con MVC la disponibilidad de nutrientes va a depender, entre otros factores, del tratamiento térmico del material durante la esterilización. Para los medios PL, PR y PT, aproximadamente el $60 \%$ de los azúcares totales se solubilizaron durante el autoclavado. En el medio PM, la solubilización fue aún mayor. Un alto porcentaje de los azúcares solubilizados corresponde a AGA, y en términos relativos, el AGA solubilizado representa el 70-90\% del originalmente presente en el material sólido. Si consideramos que 
una pectina contiene aproximadamente $70-80 \%$ de AGA, podemos inferir que la mayor parte de los azúcares solubles corresponde a sustancias pécticas extraídas durante la esterilización del medio. Esto se evidencia además en el medio RGL donde predomina el material celulósico y hemicelulósico. En este caso, los azúcares solubles representan solamente el 19 $\%$ del total.
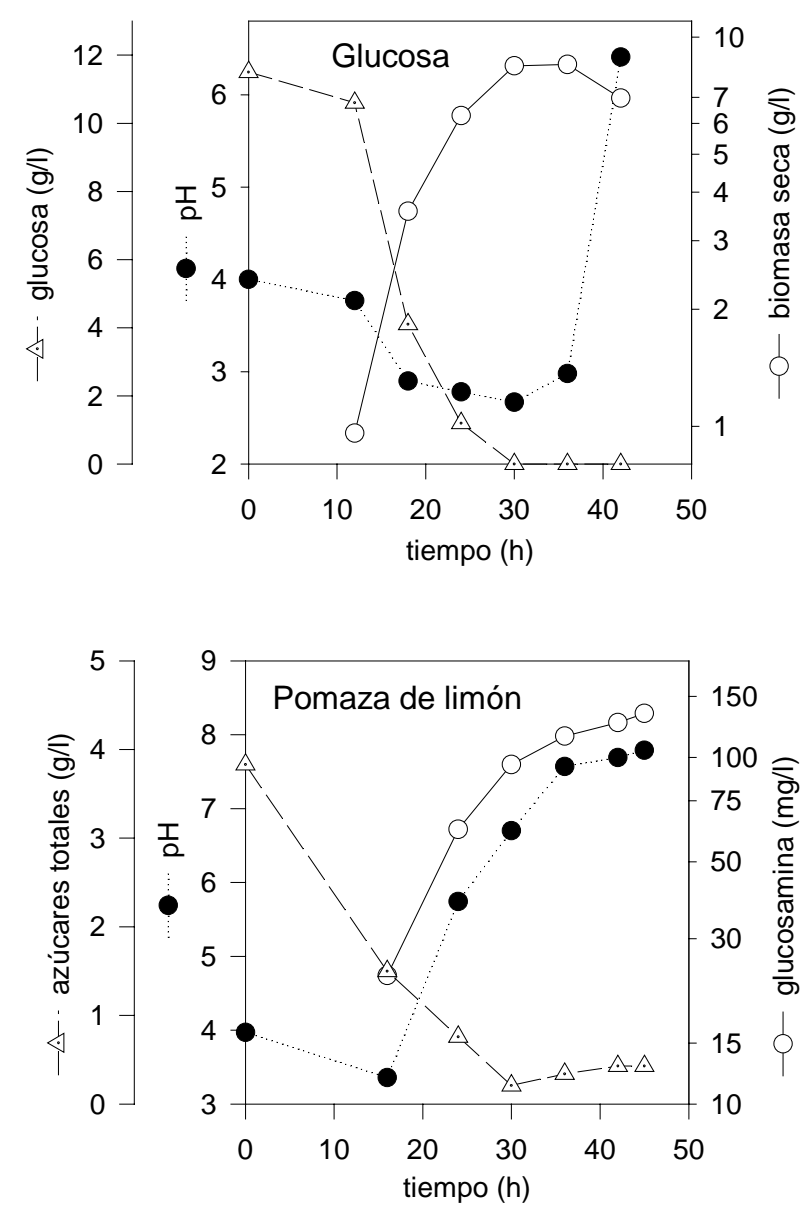

Figura 2.1. Evolución de los cultivos de A. kawachii en medios con glucosa y pomaza de limón (PL).

La evolución del cultivo en los medios conteniendo MVC se siguió en el medio PL (Figura 2.1). Se observa una fase inicial de crecimiento, hasta las $16 \mathrm{~h}$ aproximadamente, en la cual disminuye el $\mathrm{pH}$ del medio, característica similar a la observada en el medio con glucosa durante la cual se consume un $60-70 \%$ de los carbohidratos totales solubles iniciales. Luego de esta fase inicial, la evolución del cultivo cambia, el crecimiento fúngico continúa, a 
juzgar por el incremento del contenido de glucosamina en la fase sólida, y el pH del medio aumenta constantemente alcanzando valores cercanos a 7.0 a las $30 \mathrm{~h}$. A esta hora del cultivo no se detectó amonio libre en el medio, lo cual hace suponer que el aumento de $\mathrm{pH}$ no estuvo relacionado con el consumo de la triptona como fuente de carbono, situación que suele ocurrir en condiciones donde la disponibilidad de azúcar es limitada. El aumento de pH probablemente se relacione con el consumo de AGA como fuente de carbono ya que algunos cultivos realizados con pectina como única fuente de carbono mostraron una evolución de $\mathrm{pH}$ similar. Debido a la presencia de componentes insolubles, el crecimiento celular en los medios con MVC se evaluó en forma indirecta como glucosamina. Este aminoazúcar es constituyente de la quitina y quitosano, polímeros que forman parte de la pared celular de varias divisiones de hongos, entre ellos Deuteromycotina, a la cual pertenece el género Aspergillus. La estimación de biomasa por esta medida es sólo relativa, pues el contenido de glucosamina del micelio varía con la edad del cultivo, la diferenciación celular (fructificación), etc. [Aidoo et al.,1981]. En general los organos de fructificación tienen un mayor contenido de glucosamina que el micelio vegetativo. La determinación del contenido de glucosamina en la biomasa seca (30 h de cultivo en medio glucosa) presentó un valor de $2.4 \%$ (valor que se encuentra dentro del rango reportado para diferentes especies de hongos), lo cual da un rendimiento basándose en el consumo de fuente de carbono de $\sim 18 \mathrm{mg}$ glucosamina/g de glucosa consumida. Para el medio PL a las $30 \mathrm{~h}$ de cultivo el rendimiento estimado tomando en cuenta la concentración inicial de azúcares solubles fue del orden de 25 mg glucosamina/g azúcar. El valor superior respecto del medio glucosa puede atribuirse a que el consumo de fuente de carbono no fue correctamente evaluado, ya que no se consideró los carbohidratos que pudieron originarse por la degradación enzimática de los componentes insolubles de PL, o bien el crecimiento fúngico se sobrestimó si la biomasa del medio PL tiene un mayor contenido de glucosamina que la del medio glucosa.

Los parámetros de crecimiento de A. kawachii en los otros medios conteniendo MVC muestran cierta similitud con PL excepto para el cultivo RGL. A las $30 \mathrm{~h}$ se consumió la totalidad de los azúcares inicialmente solubles (incluyendo el AGA) y el pH del medio es neutro o ligeramente alcalino. Los valores de glucosamina indican crecimiento celular con rendimientos en el rango de 16-25 mg glucosamina/g azúcar inicial. La excepción la constituye el medio RGL cuya alta relación glucosamina/azúcar sugiere que el crecimiento fue mayoritariamente sustentado por la triptona ya que la disponibilidad de carbohidratos metabolizables en este medio es limitada. El incremento de glucosamina que se observa en los medios a las $40 \mathrm{~h}$ de cultivo en relación al valor de $30 \mathrm{~h}$ en puede deberse en parte a 
procesos de diferenciación celular, como la conidiación, que suele ser inducida por el agotamiento de la fuente de carbono. Podemos concluir que los MVC constituyeron una fuente de nutrientes adecuados para el crecimiento fúngico, en particular para la provisión de azúcares y ácidos orgánicos como fuente de carbono, siendo la asimilación de estos nutrientes dependiente de la degradación enzimática del material polimérico que los contiene.

Tabla 2.2. Parámetros de los cultivos de A. kawachii en medios con materiales vegetales y glucosa.

\begin{tabular}{ccccccccc}
\hline & $\begin{array}{c}\text { Azúcares solubles } \\
\text { iniciales }\end{array}$ & \multicolumn{2}{c}{ (g/l) } & \multicolumn{2}{c}{ Azúcares solubles (g/l) } & pH cultivo & \multicolumn{2}{c}{$\begin{array}{c}\text { Glucosamina } \\
(\mathbf{m g} / \mathbf{l})\end{array}$} \\
\hline Medios & Totales * & AGA & $\mathbf{3 0} \boldsymbol{h}^{*}$ & $\mathbf{4 0} \boldsymbol{h}^{*}$ & $\mathbf{3 0} \boldsymbol{h}$ & $\mathbf{4 0 ~} \boldsymbol{h}$ & $\mathbf{3 0 ~} \boldsymbol{~}$ & $\mathbf{4 0 ~} \boldsymbol{h}$ \\
\hline PL & 3.80 & 2.40 & 0.21 & $0.22(0.13)$ & 6.8 & 7.5 & $95(25)$ & 126 \\
PM & 4.66 & 1.54 & 0.22 & $0.22(0.12)$ & 7.0 & 7.7 & $80(17)$ & 202 \\
PR & 3.00 & 1.75 & 1.05 & $0.36(0.29)$ & 6.5 & 7.5 & $67(22)$ & 134 \\
PT & 3.46 & 2.27 & 0.27 & $0.39(0.13)$ & 6.9 & 7.5 & $57(16.5)$ & 70 \\
RGL & 0.95 & 0.64 & 0.21 & $0.28(0.14)$ & 6.9 & 7.1 & $52(54)$ & - \\
Glucosa & 10.0 & - & 0 & - & 2.8 & - & $177(17.7)$ & - \\
\hline
\end{tabular}

${ }^{\text {a }}$ Luego de autoclavar. * Azúcares totales determinados por el método fenol-sulfúrico. Los datos entre paréntesis de las $40 \mathrm{~h}$ de los datos de azúcares solubles indican la concentración de ácido galácturónico (AGA). Los valores entre paréntesis de los datos de glucosamina de $30 \mathrm{~h}$ indican el rendimiento: $\mathrm{mg}$ glucosamina/g azúcar total inicial - no determinado.

\subsubsection{Screening de actividades enzimáticas}

Enzimas que degradan HG y polímeros no pécticos. En la Tabla 2.3 se muestran los valores de actividad de algunas enzimas que degradan HG y polímeros no pécticos como CMC o xilano. Las actividades de celulasa y xilanasa se usaron como control ya que la síntesis de estas enzimas ha sido parcialmente caracterizada en A. kawachii. Los datos corresponden a muestras de $30 \mathrm{~h}$ de cultivo y en los casos de los medios PR y RGL a muestras de $40 \mathrm{~h}$ de cultivo (donde se observó mayor actividad enzimática). Los productos enzimáticos Olivex, Pectolyase y FP Super se emplearon como control positivo de la actividad enzimática. Las determinaciones se hicieron a $\mathrm{pH}$ 5.0-5.2 ya que éstos son los valores reportados para medir las enzimas pectolíticas fúngicas, y también a $\mathrm{pH} 2.0$ para detectar la presencia de enzimas activas a $\mathrm{pH}$ mas ácido (para ser mas clara la presentación solo se reportan en la tabla los valores a pH 2.0 de la actividad PGasa).

El nivel de expresión de xilanasas y CMCasa en el medio glucosa fue mínimo, lo cual es consistente con resultados previos que muestran que en $A$. kawachii estas enzimas se inducen en presencia del sustrato y son reprimidas por glucosa [Osawara et al., 1991]. La actividad 
xilanasa fue la que más fuertemente se indujo en los medios con MVC y resultó positiva tanto a pH 5.0 como 2.0, mientras que la actividad CMCasa solamente se detectó a pH 5.0.

Tabla 2.3. Actividades enzimáticas producida por A. kawachii en distintos medios de cultivo.

\begin{tabular}{|c|c|c|c|c|c|c|c|c|}
\hline \multirow{3}{*}{$\begin{array}{l}\text { Medio de } \\
\text { cultivo }\end{array}$} & \multicolumn{8}{|c|}{ Actividad enzimática (mU/ml)* } \\
\hline & \multicolumn{2}{|c|}{ PGasa } & \multirow{2}{*}{$\frac{\text { PeL }}{\mathrm{pH} 5.2}$} & \multirow{2}{*}{$\begin{array}{c}\text { PME } \\
\mathrm{pH} 5.1\end{array}$} & \multirow{2}{*}{$\begin{array}{c}\text { CMCasa } \\
\mathrm{pH} 5.0 \\
\end{array}$} & \multirow{2}{*}{$\begin{array}{c}\text { Xilanasa } \\
\mathrm{pH} 5.0\end{array}$} & \multirow{2}{*}{$\begin{array}{l}\mathbf{A G}^{* *} \\
\mathrm{pH} 5.0\end{array}$} & \multirow{2}{*}{$\frac{\mathbf{R G}^{* *}}{\mathrm{pH} 5.0}$} \\
\hline & $\mathrm{pH} 2.0$ & $\mathrm{pH} 5.0$ & & & & & & \\
\hline PL & 73 & 1150 & 36 & 21 & 92 & 106 & ++ & ND \\
\hline $\mathbf{P M}$ & 93.5 & 535 & 30 & 35 & 57 & 66.5 & ++ & ND \\
\hline PR & 110 & 1040 & ND & - & 91 & 59 & ++ & ND \\
\hline PT & 94 & 160 & - & 42 & 30 & 66 & ++ & ND \\
\hline RGL & 44 & 47 & - & 7.0 & 9.5 & ND & ++ & ND \\
\hline Glucosa & 28 & 276.5 & ND & ND & 8.0 & 3.5 & + & ND \\
\hline \multicolumn{9}{|l|}{$\begin{array}{l}\text { Producto } \\
\text { enzimático }\end{array}$} \\
\hline Olivex $^{a}$ & 426 & 43000 & 150 & $1.49 \times 10^{4}$ & 126 & 39 & ++ & + \\
\hline Pectolyase $^{b}$ & - & - & $2.03 \times 10^{5}$ & - & - & - & - & ND \\
\hline FP Super ${ }^{\mathrm{b}}$ & - & - & - & 1470 & - & - & - & - \\
\hline
\end{tabular}

Los datos de actividad enzimática corresponden a las $30 \mathrm{~h}$ de cultivo excepto para los medios PR y RGL que corresponden a las $40 \mathrm{~h}$ de cultivo.

*Actividades medidas por incremento del poder reductor empleando el método de Somogyi-Nelson.

Sustratos: PGasa: PGA. PeL (pectin-liasa) y PME (pectin-metilesterasa): pectina cítrica GM 53 \%. CMCasa: carboximetilcelulosa. Xilanasa: xilano.

${ }^{a}$ Producto diluido en buffer AcONa $50 \mathrm{mM}, \mathrm{pH} 5.0$ y desalinizado por pasaje a través de columna PD-10 (Pharmacia, Biotech) equilibrada con el mismo buffer.

${ }^{\mathrm{b}}$ Productos diluidos en buffer AcONa $50 \mathrm{mM}, \mathrm{pH}$ 5.0.

-: Actividad no determinada. ND: Actividad no detectada.

** AG y RG: actividad con arabinogalactano y ramnoglacturonano, respectivamente, determinadas por incremento de poder reductor luego de $12 \mathrm{~h}$ de incubación. +: actividad positiva.

Al igual que las xilanasas y celulasas, la actividad pectolítica dependió del medio de cultivo. La presencia de actividad PGasa en el medio con glucosa indica que la síntesis de estas enzimas es parcialmente constitutiva. La actividad PGasa se manifestó tanto a pH 5.0 como 2.0 y se incrementó dos a cuatro veces en los medios PL, PR y PM en comparación con el medio con glucosa. La relación entre la actividad PGasa a pH 5.0 y 2.0 fue variable, lo cual sugiere que diferentes PGasas son inducidas en los distintos medios de cultivo. Un dato llamativo es el menor valor de actividad PGasa a pH 5.0 en el medio PT respecto a glucosa, lo cual es difícil de explicar. Por otra parte, es interesante destacar la presencia de una actividad PGasa a pH 2.0 en el producto Olivex. Con respecto a PeL y a PME, estas actividades no se 
detectaron en el medio con glucosa, expresándose en los medios conteniendo MVC, lo cual indica que son inducibles. La presencia de PME activa a $\mathrm{pH} 2.0$ y a pH 5.0 fue confirmada midiendo el metanol liberado en la reacción, ya que el método espectrofotométrico (que mide la acidificación producida por la formación de grupos carboxílicos libres) está adaptado para estimar la presencia de PME a pH alrededor de 5.0. Los valores de PME en el medio PL fueron de 11.7 y $33.4 \mathrm{mU} / \mathrm{ml}$ a pH 2.0 y 5.0, respectivamente. La actividad PeL se detectó únicamente a pH 5.0 y fue específica de pectina, es decir no se detectó actividad pectato-liasa ni RG-liasa. Un caso particular es el medio RGL en el cual los niveles de todas las enzimas analizadas fueron bajos. Es evidente que este medio no provee inductores para la síntesis enzimática, debido probablemente a su estructura predominantemente lignocelulósica que dificulta su degradabilidad.

Glicosidasas y enzimas que degradan RG. En la Figura 2.2 se muestran la actividad glicosidasa encontrada en los distintos medios de cultivo para los distintos sustratos ensayados. En el medio glucosa se detectó una mínima actividad $\beta$-glucosidasa y $\beta$ galactosidasa. Estas actividades se incrementaron muy significativamente en los medios conteniendo MVC, en particular PL, PR y PM. Paralelamente se determinaron altos niveles de actividad $\alpha$-L-arabinofuranosidasa y, en mucha menor proporción, actividad ramnosidasa (en particular en el medio PL) y $\beta$-D-fucopiranosidasa. La actividad frente a p-nitrofenil- $\alpha$-Lxilosa fue muy baja en todos los casos. No se encontró una relación entre la composición de azúcares de los materiales vegetales y los niveles de las distintas actividades glicosídicas. Por ejemplo, el alto porcentaje de arabinosa en PR no implicó un aumento sustancial de la actividad $\alpha$-L-arabinofuranosidasa. La composición de azúcares neutros de los materiales vegetales es orientativa en cuanto a la predominancia de ciertos polisacáridos en el tejido vegetal, pero esta composición no indica la presencia de otros componentes que pueden actuar como inductores de la síntesis de enzimas. Tal es el caso de glicósidos que contienen ramnosa, como narinigina, que son inductores de la actividad ramnosidasa o $\beta$-glucosidasa [Norouzian et al., 2000]. Estos glicósidos están presentes en los cítricos lo cual explicaría el mayor nivel de ramnosidasa encontrado en el medio PL.

Un objetivo importante del screening fue determinar la presencia de enzimas que degradan $\mathrm{RG}$, fundamentalmente el esqueleto principal (acción endo). Para la detección de las actividades sobre $\mathrm{RG}$, el sustrato comúnmente empleado es una fracción enriquecida derivada de la licuefacción de manzana, llamada región pilosa modificada - modified hairy region (MHR) [Mutter, 1997]. MHR se aísla de jugo de manzana proveniente del proceso de 
licuefacción, el cual se lleva a cabo con el uso de productos enzimáticos comerciales como Rapidase C600 (Gist Brocades). La MHR contiene una alta proporción de Ara y Gal que derivan de las cadenas laterales del RG y un bajo contenido en Xil. Como el RG suele estar esterificado y acetilado, se lo saponifica para eliminar las uniones ésteres y hacerlo más susceptible a la hidrólisis de las enzimas. En nuestro caso se decidió emplear un sustrato relativamente nuevo, el RG de soja producido por Megazyme. Este sustrato es preparado a partir de fibras de soja mediante la hidrólisis exhaustiva con enzimas pécticas, celulasas y proteasas. La estructura resultante es resistente a la degradación por endo-xilanasas y $\alpha-\mathrm{L}-$ arabinofuranosidasas. El producto comercial tiene bajo contenido de Ara y Gal debido al tratamiento enzimático efectuado con $\beta$-galactosidasa y $\alpha$-L-arabinofuranosidasas que remueve las cadenas laterales. Esto aumenta el contenido relativo de residuos Xil que se encontrarían unidos al AGA en el xilogalacturonano o a Ram en el RG. En la Tabla 2.4 se presenta la composición del RG comercial y la denominada región pilosa modificada que contiene RG.
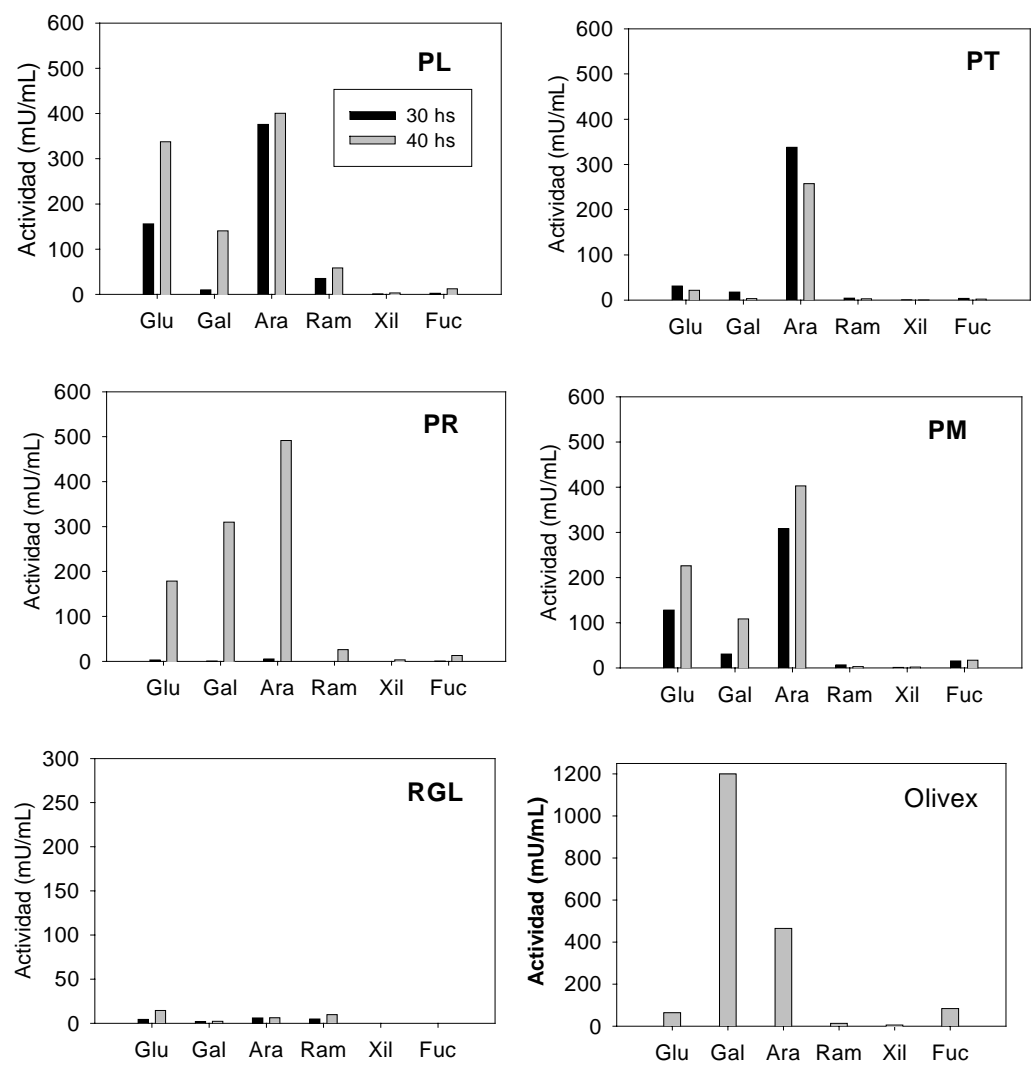

Figura 2.2. Actividad glicosidasa producida por A. kawachii en distintos medios complejos en comparación con un producto enzimático comercial (Olivex). 
Tabla 2.4. Composición de RG de soja y de manzana (moles \%).

\begin{tabular}{lcc}
\hline \multicolumn{1}{c}{ Azúcar } & RG de soja * & RG de manzana ** \\
& & \\
\hline Ac. galacturónico & 48 & 33 \\
Ramnosa & 18.5 & 16 \\
Arabinosa & 6.5 & 20 \\
Galactosa & 1.1 & 18 \\
Xilosa & 25.2 & 11 \\
\hline * Producto de Megazyme. & \multicolumn{2}{|}{ ** Región pilosa modificada y desesterificada [Schols, 1995]. }
\end{tabular}

Para la detección de la actividad sobre RG se emplearon 3 métodos: a) incremento de poder reductor, b) análisis por tamiz molecular de los productos de hidrólisis y c) test en placa. En el caso a) se incubó una solución de sustrato con muestras de enzima durante 12 h y el poder reductor liberado se determinó por Somogyi-Nelson. En la Tabla 2.5 se muestran los resultados obtenidos con muestras de $30 \mathrm{~h}$ de los cultivos glucosa y PL y el producto Olivex. Se incluye además resultados obtenidos con AG como sustrato indicador de hidrólisis de cadenas laterales de arabanos y galactanos. Cuando el RG se incubó a pH 5.0 con el producto Olivex se observó un incremento neto de reductores de $4.2 \mu \mathrm{mol} / \mathrm{ml}$ (expresados como AGA), lo cual indica que hubo degradación del sustrato. Con las muestras de los cultivos, no se detectó incremento significativo en la concentración de reductores. Cuando se empleó AG como sustrato, el incremento del poder reductor se observó con el producto enzimático a $\mathrm{pH}$ 5.0 y con el medio PL tanto a pH 5.0 como 2.0. La mínima actividad en el medio glucosa sugiere que las enzimas que degradan AG son inducibles y esta actividad puede estar relacionada también con las actividades glicosídicas antes descriptas.

Tabla 2.5. Hidrólisis de RG y AG evaluada por medidas de poder reductor.

\begin{tabular}{ccccc}
\hline \multicolumn{5}{c}{ Azúcares reductores $(\mu \mathrm{mol} / \mathrm{ml})$} \\
\hline & \multicolumn{3}{c}{ RG } & \multicolumn{3}{c}{ AG } \\
\hline & $p H$ 2.0 & $p H 5.0$ & $p H 2.0$ & $p H 5.0$ \\
\hline Blanco * & 2.4 & 2.55 & 0.926 & 0.80 \\
Glucosa 24 & 2.2 & 2.16 & 0.977 & 0.88 \\
PL 24 & 2.3 & 2.87 & 1.23 & 1.77 \\
Olivex & 2.8 & 7.02 & 0.996 & 1.84 \\
\hline
\end{tabular}

Condiciones de reacción: $1 \mathrm{ml}$ de solución al 0.5 \% RG o AG en AcONa pH 5.0 + $50 \mu$ l de enzima. Glucosa 24 y PL 24: muestra $10 \times$. Olivex: producto diluido 1:50 * Sustrato sin enzima. 
El incremento de poder reductor en sustratos poliméricos indica la presencia de enzimas que lo degradan tanto en forma endo como exo. Para establecer qué tipo de actividad sobre RG contiene Olivex, se determinó la distribución de productos mediante cromatografía de tamiz molecular. Como controles se emplearon un blanco de sustrato y las muestras incubadas con el medio PL. Los resultados se muestran en la Figura 2.3.

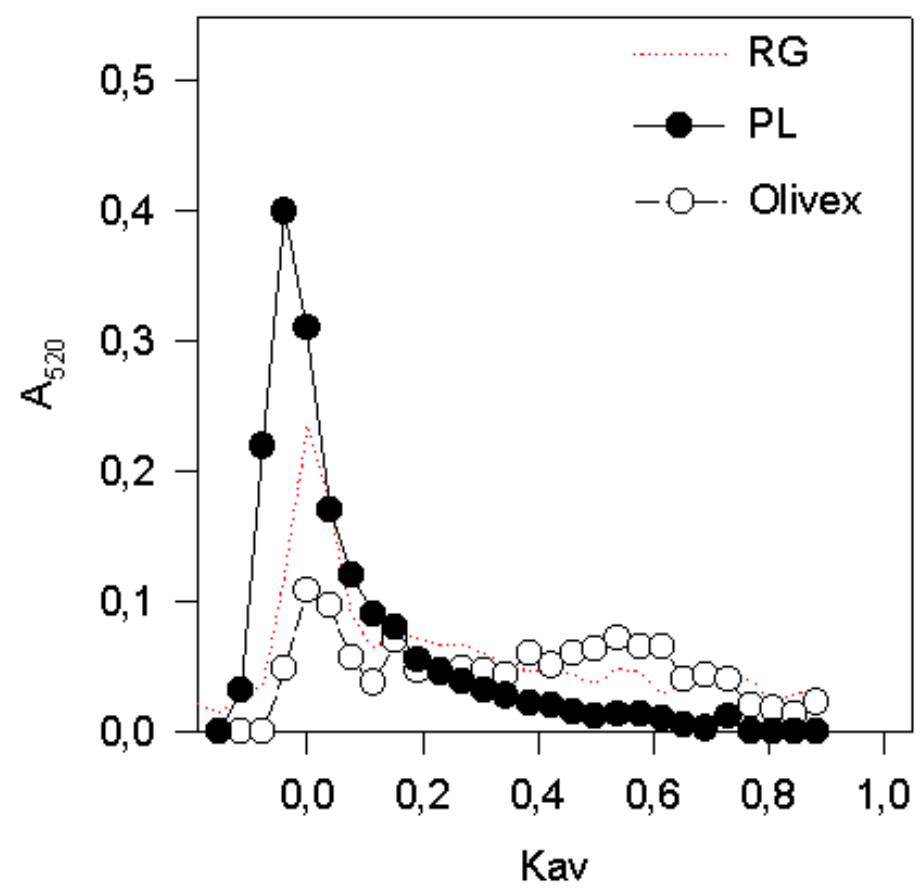

Figura 2.3. Cromatografía en tamiz molecular de RG.

Cromatografía en gel: Sephacryl S-100 (XK 16/70, 100 ml gel) equilibrada con AcONa 50 mM, pH 3.5 conteniendo $0.15 \mathrm{M} \mathrm{NaCl}$. La columna se calibró con azul dextrano y glucosa. El volumen de muestra inyeactado fue $500 \mu \mathrm{l}$, el caudal $30 \mathrm{ml} / \mathrm{h}$ y el volumen de fracción recolectado $2 \mathrm{ml}$. La determinación de carbohidratos totales en las fracciones recolectadas se realizó por el método del Fenol-Sulfúrico y se expresa como Absorbancia.

El RG incubado con muestras de cultivo PL eluye en el volumen de exclusión en forma similar al blanco (sustrato incubado sin enzima) confirmando la ausencia de una degradación significativa tanto endo como exo. En cambio el sustrato incubado con Olivex presenta una distribución de productos de menor peso molecular característico de la hidrólisis endo ya que eluyen en valores intermedios de Kav. Resultados similares se obtuvieron en la cromatografía de tamiz molecular de muestras de AG incubadas con Olivex y PL (figura no mostrada). 
Resultó muy interesante desarrollar un test de difusión en placa para visualizar la actividad sobre RG. Un test ha sido propuesto para detectar la degradación de la MHR. La acción endo sobre el sustrato se revela mediante el agregado de una solución de $\mathrm{Cu}^{+2}$ que produce una opalescencia blanca alrededor de la muestra positiva. La reacción de precipitación estaría relacionada con la interacción del $\mathrm{Cu}^{+2}$ con el XG que es liberado por la acción enzimática [Mutter, 1997]. Cuando este test se aplicó a placas conteniendo el RG de Megazyme, los resultados fueron poco satisfactorios, es decir la reacción no se detectó claramente. Circunstancialmente se encontró que el revelado con rojo de rutenio (empleado en el test de PGasa o PME) daba lugar a un halo nítido, siendo esta reacción únicamente observada con el producto Olivex. La tinción se aplicó también para visualizar bandas de actividad en geles de SDS-PAGE. En la Figura 2.4 se muestran los resultados del test en placa y del zimograma donde se observan el halo y las bandas de hidrólisis. Las enzimas con actividad RGasa en el preparado Olivex presentaron un peso molecular de 67.3, 63.7, 57.3, y $48.8 \mathrm{kDa}$. El test en placa resultó negativo para todas las muestras de cultivo ensayadas. Esto demuestra en parte la especificidad del test ya que los concentrados enzimáticos obtenidos de los medios con MVC muestran actividades enzimáticas comunes con Olivex. Es evidente que ninguna de estas enzimas en el producto comercial es responsable de la degradación del RG. Con fines comparativos se muestran en la Tabla 2.6 las actividades presentes en las muestras del medio PL y Olivex usadas en el test en placa.

Tabla 2.6. Actividades de las muestras empleadas en el test de placa para detectar actividad RG.

\begin{tabular}{ccccccc|ccccccc}
\hline \multicolumn{4}{c}{ Actividad sobre sustratos poliméricos $(\mathbf{m U} / \mathbf{m l}) *$} & \multicolumn{5}{c}{ Actividad glicosidasa $(\mathrm{mU} / \mathrm{ml}) * *$} \\
\hline & CMC & Xilano & PGA & PeL & PME & AG & Ara & Glu & Gal & Ram & Fuc & Xil \\
\hline PL $(10 \times)$ & 920 & 1060 & 11500 & 380 & 210 & + & 3760 & 1560 & 450 & 356 & 29 & 12.8 \\
Olivex 1:50 & 126 & 39.2 & 43000 & 150 & 14900 & + & 465 & 65 & 1200 & 14.5 & 84 & 6.2 \\
\hline
\end{tabular}

* Medidas a pH 4.5-5.2** Medidas a pH 4.5. PL muestra de $30 \mathrm{~h}$, concentrado $10 \times$

Actividad sobre sustratos insolubles. El screening de la actividad pectolítica se realizó también con sustratos insolubles, en este caso con protopectina de limón. La actividad PPasa se manifestó tanto en el medio con glucosa como PL y fue positiva a $\mathrm{pH} 2.0$ y 5.0. La actividad PPasa del medio glucosa a las $30 \mathrm{~h}$ de cultivo fue de 0.9 y $0.2 \mathrm{U} / \mathrm{ml}$ a pH 2.0 y 5.0, respectivamente (ver Figura 2.5). La actividad PPasa de PL no se determinó. 

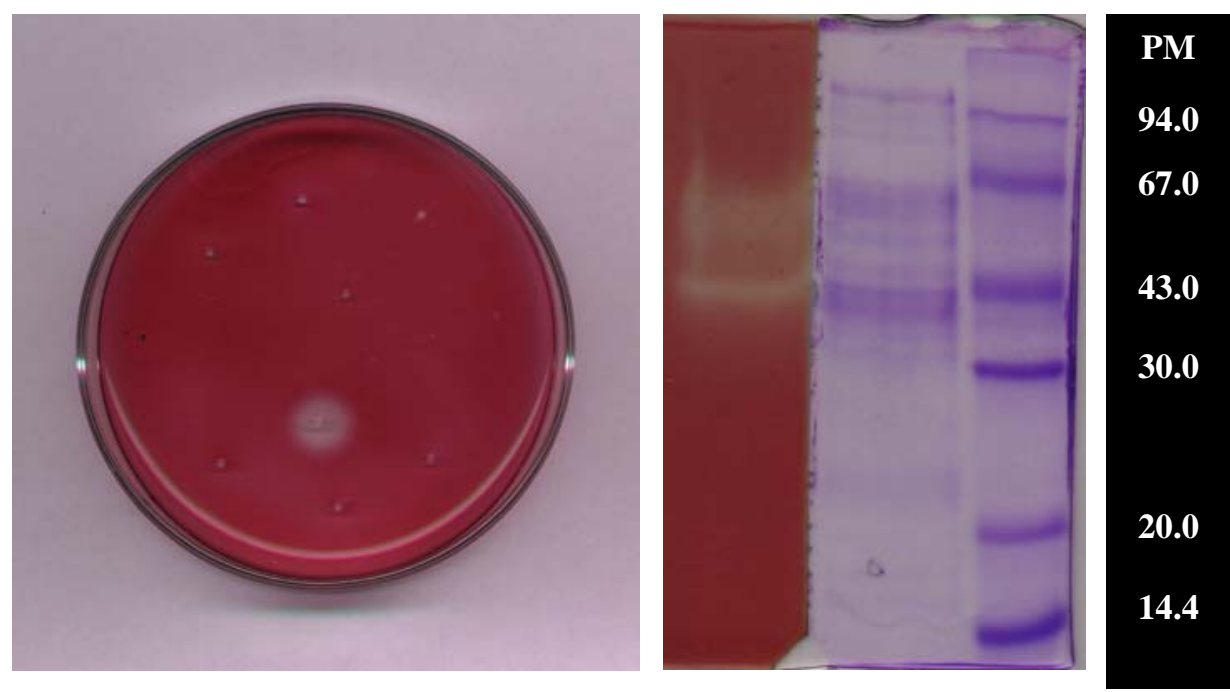

Figura 2.4. Test de placa y SDS-PAGE para detectar actividad sobre RG.

\begin{abstract}
Gel en placa: $1 \%$ agarosa en buffer AcONa $50 \mathrm{mM}$, pH 4.5 conteniendo $0.25 \%$ RG. Incubación: 6 h a $37{ }^{\circ} \mathrm{C}$. Revelado: $0.02 \%$ rojo de rutenio en agua.

Halo positivo: Olivex $20 \mu$ l, dilución 1:50, el resto muestras de los cultivos con MVC.

Zimograma: SDS-PAGE conteniendo $0.25 \%$ de RG. Muestra: Olivex $20 \mu$ l, dilución 1:50. Incubación luego de la corrida: $4 \mathrm{~h}$ a $37^{\circ} \mathrm{C}$ en buffer AcONa $50 \mathrm{mM}, \mathrm{pH} 4.5$. Revelado: $0.02 \%$ rojo de rutenio en agua. Bandas de proteína y patrones de PM: tinción con Coomasie Blue.
\end{abstract}

\title{
2.3.3. Adsorción de enzimas a filtros de fibra de vidrio
}

Durante el desarrollo de los primeros cultivos se pudieron observar inconsistencias en los patrones de actividad enzimática correspondiente a la actividad PPasa y PGasa, particularmente las determinadas a $\mathrm{pH}$ 5.0. Mientras que las actividades a $\mathrm{pH} 2.0$ eran reproducibles en las diferentes etapas del procesamiento de las muestras y en diferentes lotes de cultivo, los valores a pH 5.0 eran irregulares y en algunos casos estas actividades no se detectaban. Luego de varios ensayos se pudo constatar que este comportamiento se debía a la adsorción de la actividad PGasa a los filtros de fibra de vidrio (FFV) empleados para clarificar las soluciones de enzima. La adsorción de las actividad PGasa al filtro se verificó al incubar dicho filtro con una solución de sustrato (APG) y observar incremento de poder reductor. El fenómeno de adsorción resultó ser $\mathrm{pH}$ dependiente observándose un máximo a pH 3.0. Resultó interesante determinar los perfiles de pH/actividad para PGasa y PPasa antes y después de filtrar el medio por el FFV. A tal fin, se utilizó una muestra del medio glucosa de $30 \mathrm{~h}$ ya que en este medio ambas actividades son significativas existiendo además una mínima cantidad de proteínas contaminantes. La separación primaria del micelio del medio de fermentación se efectuó empleando una tela de nylon (cheese cloth), luego de lo cual se centrifugó para eliminar restos de material insoluble (medio centrifugado, MC). El MC 
obtenido se ajustó el pH a 3.0 y se filtró por el FFV empleando un soporte de polisulfona. Experimentos separados demostraron que el soporte de polisulfona es totalmente inerte ya que no adsorbe ninguna de las actividades enzimáticas en cuestión. En la Figura 2.5 se muestran las curvas de actividad/pH de MC y permeado.
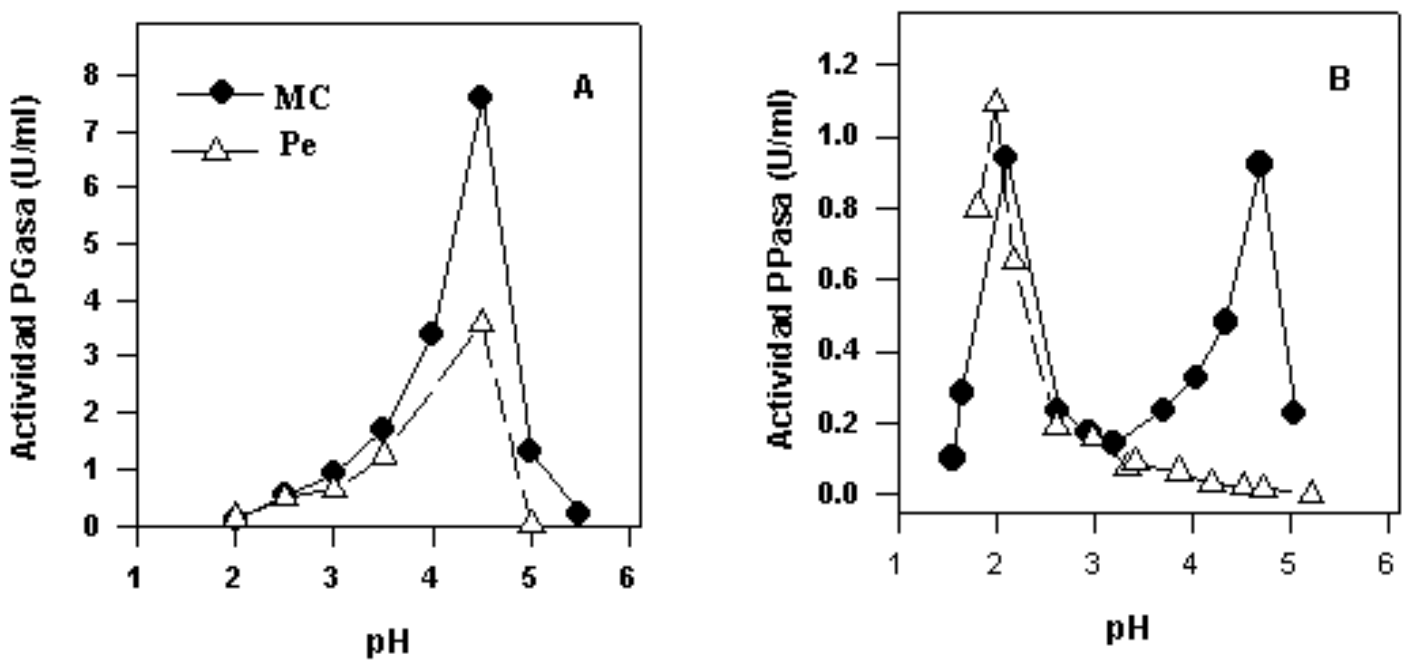

Figura 2.5. Curvas de actividad/pH para PGasa y PPasa antes (MC) y después (Pe) de filtrar por filtro de fibra de vidrio. A) actividad PGasa y B) actividad PPasa.

MC: (-๑-) y Pe: (- - $\triangle$ - -).

En MC la actividad sobre APG se manifiesta desde $\mathrm{pH} 2.0$ hasta 5.5 con un máximo en 4.5-4.7. Con protopectina el rango de actividad se extiende hasta $\mathrm{pH} 1.6$ en la región más ácida y presenta 2 picos: a $\mathrm{pH} 1.8-2.0$ y a $\mathrm{pH}$ 4.7-4.8. En el permeado tanto la actividad PGasa a $\mathrm{pH} 5.0$ como la PPasa a $\mathrm{pH} 4.7$ resultaron prácticamente negligibles, en contraste no se observaron cambios en dichas actividades a valores de $\mathrm{pH} \leq 3.0$. De estos resultados podemos inferir que $A$. kawachii produce en el medio glucosa al menos dos grupos de enzimas con actividad PGasa y PPasa. Un grupo corresponde a las enzimas que son activas sobre APG y protopectina a $\mathrm{pH} 2.0$, pero inactivas sobre estos sustratos a $\mathrm{pH} 5.0$, las cuales no se adsorben al FFV (de aqui en mas denominadas PGasa o PPasa ácida). El otro grupo son las enzimas activas sobre estos sustratos a $\mathrm{pH} 5.0$ pero inactivas a $\mathrm{pH} 2.0$ que tiene la propiedad de adsorberse al FFV (de aqui en mas denominadas PGasa o PPasa moderadamente ácida). Considerando que en el medio glucosa no se detectó la presencia de PME, PeL o RGasa, y 
que la actividad PPasa no define una clase especial de pectinasas, se reivindicó como más probable que ambas actividades, PPasa y PGasa, sea efectuada por una misma proteína. Esta presunción se confirmó luego durante la caracterización de las enzimas purificadas. Teniendo en cuenta la presencia de enzimas que degradan pectina a pH 2.0 y la baja o nula expresión de otras actividades enzimáticas, se decidió purificar las pectinasas ácidas a partir del medio glucosa dejando para un estudio posterior la purificación de enzimas de los medios con MVC. Previo al proceso de purificación se efectuaron algunas experiencias para determinar si la actividad solubilizadora de pectina del medio glucosa era térmicamente estable y si efectivamente era capaz de extraer pectina de alto peso molecular con aceptable rendimiento. Para ello se utilizó el permeado obtenido luego de filtrar CM por el FFV que contiene a la actividad ácida casi como única actividad pectolítica.

\subsubsection{Estabilidad térmica de la actividad PPasa ácida}

Para determinar la estabilidad térmica de la actividad PPasa ácida, se incubó el permeado a diferentes temperaturas. El permeado se trató previamente con pepstatina-A para inhibir a la proteasa ácida y eliminar un posible factor desestabilizante durante la incubación, luego se dializó frente a BCP, pH 3.0. La concentración de proteína en el dializado fue de $0.3 \mathrm{~g} / \mathrm{l}$ no detectándose actividad proteolítica. Las curvas de PPasa residual en función de la temperatura se presentan en la Figura 2.6. Como se puede observar, la actividad fue estable a $50{ }^{\circ} \mathrm{C}(15 \%$ de pérdida de actividad luego de $10 \mathrm{~h}$ de incubación).

\subsubsection{Extracción enzimática de pectina de limón}

La actividad PPasa mide la solubilización de sustancia pécticas a tiempos cortos de reacción (velocidad inicial), siendo el porcentaje de AGA solubilizado en estas condiciones del orden de 1-3\%. Para extraer pectina eficientemente se necesitan rendimientos mayores además de asegurarse que el material extraído sea de alto PM. Por lo tanto se efectuó un estudio de extracción de pectina utilizando como sustrato cáscaras de limón. Los limones frescos fueron tratados térmicamente para inactivar las enzimas nativas, particularmente PME. Como fuente de enzima se empleó el permeado del medio glucosa tratado con pepstatina, dializado frente a $\mathrm{BCP}, \mathrm{pH} 3.0$ y diluido a un tercio con agua. $\mathrm{El} \mathrm{pH}$ de la suspensión de cáscaras de limón fue 3.2-3.5 que no se modificó (aunque no es el óptimo). En la Figura 2.7 se presentan fotografías de tubos graduados donde se visualiza la precipitación de material péctico extraído por la acción enzimática. El rendimiento fue $17.4 \%$ de pectina en base a cáscara seca, mientras que los blancos presentaron un 4\% de extracción. Es evidente 
que la actividad PPasa ácida extrae pectina de alto peso molecular de las cáscaras de limón con rendimiento aceptable.

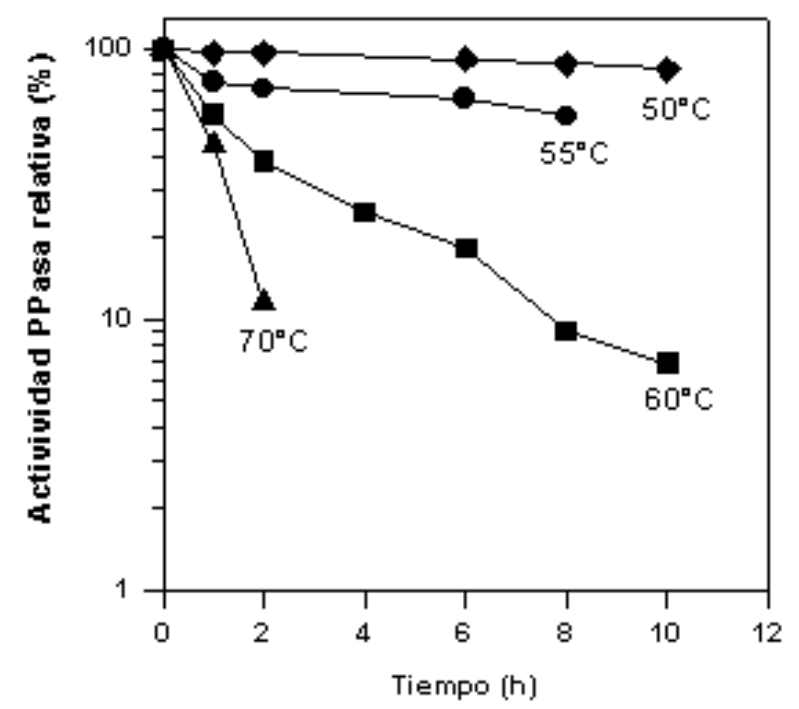

Figura 2.6. Estabilidad térmica de la actividad PPasa ácida.

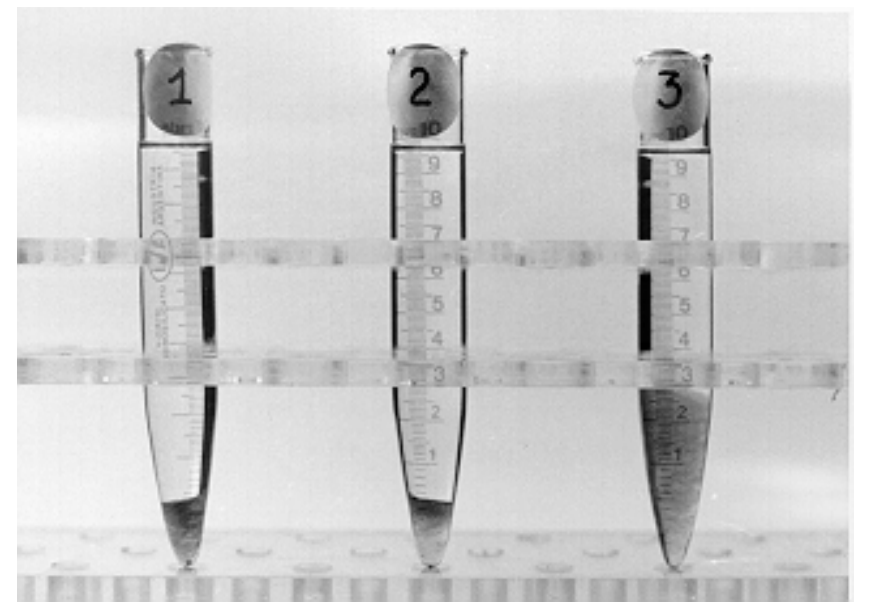

Figura 2.7. Extracción enzimática de pectina con A. kawachii

Visualización de la pectina extraída de cáscara de limón luego de incubar durante por $2 \mathrm{~h}$ a $50{ }^{\circ} \mathrm{C}$ y pH 3.2-3.5 el material sólido con un dializado de medio glucosa. Previo a la diálisis el medio glucosa ajustó a pH 3.0 y se filtró por membranas de fibra de vidrio.

1) agua (control). 2) BCP diluido con agua 1:3, control buffer. 3) extracto de cultivo dializado. 


\subsection{Discusión}

El screening de la actividad pectinolítica demostró que A. kawachii posee un sistema pectolítico constituido principalmente por PME, PeL, PGasas y diversas glicosidasas, pero no produce (o al menos no pudo detectarse por las técnicas empleadas) una actividad enzimática que degrade el esqueleto principal del RGI así como de la región del XG. Las PGasas se expresaron de modo parcialmente constitutivo y son activas en un amplio rango de $\mathrm{pH}$ (2.05.5). Un resultado similar se observó cuando la actividad se determinó con un sustrato insoluble como protopectina. La actividad PGasa total se incrementa en los medios conteniendo MVC, probablemente por una mayor síntesis de estas PGasas y/o por la inducción de otras proteínas con dicha actividad. Otras enzimas que degradan la región del HG como PME y PeL no se expresaron en el medio con glucosa pero se indujeron por los MV.

El análisis de los niveles de enzima en el medio glucosa es siempre controvertido pues este azúcar suele ser responsable de la represión de muchos genes inducibles. Sin embargo, cultivos llevados a cabo con glicerol mostraron que el crecimiento con esta fuente de carbono no produce aumento de la actividad PGasa ni la expresión de las otras enzimas ensayadas, lo cual demuestra que la presencia de estas enzimas en los medios conteniendo MVC es preponderantemente un efecto inductivo. En este sentido, la regulación de la síntesis de las pectinasas de A. kawachii es comparable a la descripta en otras especies de Aspergillus [Pareniková, 2000].

Un resultado importante de este estudio fue la ausencia en los medios de cultivo de actividad sobre RG. El RG empleado es diferente al reportado en otros trabajos, en particular por la ausencia de cadenas laterales conteniendo residuos de Ara y Gal. El esqueleto principal contiene las uniones características de Ram-AGA-Ram e incluye una región de XG. El test de difusión en placa desarrollado y el análisis de productos de degradación por cromatografía de tamiz molecular dan resultados consistentes demostrando que el producto comercial Olivex contiene enzimas que degradan este sustrato en forma endo, es decir cortan la estructura interna de la cadena del polímero generando oligómeros cuyo peso molecular decrece con el avance de la reacción. Esta acción estaría mediada básicamente por la RG-hidrolasa y RGliasa [Mutter, 1997] (ver Capítulo 1) cuya acción es de tipo endo. Se han descripto enzimas que degradan en forma exo el RG como también la región del XG (ver Capítulo 1). La contribución de estas enzimas a la degradación del RG no fue específicamente evaluada, sin embargo la cromatografia por gel no mostró presencia significativa de productos monoméricos o diméricos que eluyen con el volumen de columna, lo cual sugiere que la 
degradación exo, si la hubo, fue muy limitada. Es evidente que el producto Olivex contiene enzimas que atacan el RG que no son producidas por A. kawachii. Obviamente ninguna de las actividades comunes que se encuentran en el producto comercial y los medios de cultivo como las descriptas en la Tabla 2.6 son las responsables en el Olivex de la degradación del RG.

El screening con glicósidos cromogénicos mostró que A. kawachii es una fuente importante de actividad arabinofuranosidasa y $\beta$-galactosidasa. Estas enzimas han sido ampliamente caracterizadas en otros hongos filamentosos [de Vries, 1999; Saha, 2000; Samoshina et al., 2000]. Existen ciertas diferencias con relación a la especificidad de la reacción que catalizan. En Aspergillus sp. se ha detectado una única enzima con actividad $\beta$ galactosidasa que hidroliza los residuos terminales de galactosa presentes en las regiones pilosas de la pectina. Su acción es bastante específica. En el caso de las arabinofuranosidasas se han purificado varias enzimas con diferentes propiedades y especificidades de sustrato. Esto es debido a que la L-arabinosa está ampliamente distribuida, es decir es componente no sólo de la pectina sino también de otros polímeros como la hemicelulosa, ciertas gomas, etc. [Saha, 2000].

Otro azúcar frecuentemente encontrado en la pectina es la fucosa. La presencia de actividad $\beta$-fucosidasa fue muy baja comparada con las actividades arabinofuranosidasa y $\beta$ galactosidasa, quizá debido a la baja cantidad de fucosa presente en los MVC. La posibilidad de que la actividad fucosidasa sea una actividad residual de las principales enzimas detectadas no debe ser descartada. La actividad fucosidasa en hongos ha sido descripta en el fitopatogéno Sclerotinia sclerotiorum [Riou et al., 1991] y en A. oryzae [Samoshina et al., 2000]. De este último se han purificado y caracterizado diversas $\alpha$ - y $\beta$-fucosidasas. El uso de $\alpha$-fucosidasas está ganando importancia para producir fucosa o fuco-oligosacáridos a partir del polisacárido marino fucoidano [Tanaka and Sorai, 1970]. Hasta el momento, no hay $\alpha$-fucosidasas microbianas disponibles en el mercado para la degradación específica del fucoidano [Daniel et al., 1999]. Sería muy interesante realizar la búsqueda de $\alpha$-fucosidasas en A. kawachii capaces de degradar fucoidano en forma exo o endo, ya que el sustrato empleado para detectar la actividad en el presente trabajo es de configuración $\beta$.

Otras actividades glicosídicas que se indujeron en los medios con MVC no necesariamente se relacionan con la hidrólisis de sustratos pécticos. Estas actividades corresponden a pnp- $\alpha$ L-ramnohidrolasa (ramnosidasa), pnp- $\beta$-D-glucosidasa y pnp- $\alpha$-xilosidasa. La actividad $\beta$ glucosidasa es parte del complejo enzimático responsable de la degradación de la celulosa y 
ha sido extensamente estudiada en A. kawachii (Tabla 1.1). La actividad ramnosidasa es responsable de la hidrólisis de varios flavonoides, como naringina o hesperidina, que suelen estar presentes en los cítricos [Puri and Banerjee, 2000]. En general es específica de enlaces $\alpha-(1,2)$ y $\alpha-(1,6)$ entre ramnosa y glucosa. La actividad ramnosidasa se complementa con la $\beta$-glucosidasa que hidroliza la unión de la glucosa con el aglicón. Cabe destacar que la hidrólisis de la ramnosa terminal en RG es llevada a cabo por una exo-enzima altamente específica y no por la clásica ramnosidasa [Mutter, 1997]. Por su parte, la actividad $\alpha$ xilosidasa es de utilidad en la degradación de hemicelulosas y complementa la actividad de las xilanasas[de Vries, 2000].

Si bien las enzimas responsables de la actividad sobre los glicósidos no se purificaron, cabe mencionar que estudios posteriores usando cromatografía de intercambio aniónico mostraron que la actividad $\beta$-galactosidasa, $\alpha$-L-arabinofuranosidasa y $\alpha$-L-ramnosidasa presente en los cultivos PL son debidas a enzimas diferentes [Vita et al., 2001]. Para la actividad $\beta$-galactosidasa y $\alpha$-L-arabinofuranosidasa se detectó un único pico de actividad mientras que dos fracciones con actividad $\alpha$-L-ramnosidasa fueron detectadas en el mismo sistema cromatográfico.

Desde el punto de vista de los objetivos del trabajo, el resultado destacable del screening fue la presencia en los medios de cultivo de actividad PGasa o PPasa a pH muy ácido (pH 2.0) que fue el objetivo principal de la búsqueda. Si bien diferentes enzimas pueden expresarse en los diferentes medios ensayados, se decidió purificar las enzimas del medio glucosa ya que este contiene una mucho menor carga de contaminantes en relación con los medios con MVC. La adsorción de algunas de estas enzimas a FFV permitió establecer que al menos dos grupos de PGasas/PPasas se producen en el medio glucosa. Las enzimas activas a pH 2.0 no se adsorben al filtro, mientras que las activas a $\mathrm{pH} 5.0$ (pero inactivas a $\mathrm{pH}$ 2.0) si se adsorben. El permeado conteniendo la actividad ácida resultó apropiada para realizar una caracterización preliminar de la actividad solubilizadora de pectina. Lo más destacable fue su estabilidad térmica y la capacidad de solubilizar pectina de alto peso molecular a partir de cáscara de limón con aceptable rendimiento.

En conclusión, A. kawachii constituye una fuente de pectinasas ácidas que pueden ser usadas para la degradación tanto de sustratos solubles como insolubles. 


\subsection{Bibliografía}

Aidoo, K.E.; Hendry, R. and Wood, B.J.B. (1981). Estimation of fungal growth in a solid state fermentation system. European J. Appl. Microbiol. Biotechnol., 12:6-9.

Albersheim, P. (1966). Pectin lyase from fungi. Methods in Enzymology, 8:628-631.

Baquero, C. y Bermudez, A.S. (1998). En: Temas en Tecnología de Alimentos. F.M. Lajolo and E. Wenzel de Menses (Eds.). Vol. 2. Fibra dietética. Programa Iberomaericano de Ciencia y Tecnología para el Desarrollo (CYTED)-Instituto Politécnico Nacional (IPN), México. pp:207-214.

Blumenkrantz, N. and Asboe-Hansen, G. (1973). New method for quantitative determination of uronic acids. Analytical Biochemistry, 54:484-489.

Bonnin, E.; Brunel, M.; Gouy, Y.; Lesage-Meessen, L.; Asther, M. and Thibault, J.F. (2001). Aspergillus niger I-1472 and Pycnoporus cinnabarinus MUCL39533, selected for the biotransformation of ferulic acid to vanillin, are also able to produce cell wall polysaccharide-degrading enzymes and feruloyl esterases. Enzyme Microbiology and Technology, 28:70-80.

Cavalitto, S.F.; Hours, R.A. and Mignone, C.F. (1997). Quantification of pectin-releasing activity of protopectinase-SE from Geotrichum klebahnii. Biotechnology Techniques, 11:331-334.

Cavalitto, S.F.; Arcas, J.A. and Hours, R.A. (1996). Pectinase production profile of Aspergillus foetidus in solid state cultures at different acidities. Biotechnology Letters, $18: 251-256$.

Contreras-Esquivel, J.C.; Hours, R.A.; Voget, C.E. and Mignone, C.F. (1999). Aspergillus kawachii produces an acidic pectin releasing enzyme activity. Journal of Bioscience and Bioengineering, 88:48-52.

Contreras-Esquivel, J.C. and Voget, C.E. (2001). Detection of rhamnogalacturonan degrading enzymes in polyacrylamide gels. $11^{\text {th }}$ World Congress of Food Science and Technology, April 22-27, COEX, Seoul, South Korea.

Cooper, R.M. and Wood, R.K.S. (1973). Induction of synthesis of extracellular cell-wall degrading enzymes in vascular wilt fungi. Nature, 246:309-311.

Couri, S.; Da Costa Terzi, S.; Pinto, G.A. Saavedra; F., Suely-Pereira and Da Costa, A.C.A. (2000). Hydrolytic enzyme production in solid-state fermentation by Aspergillus niger 3T5B8. Process Biochemistry, 36:255-261. 
Daniel, R.; Berteau, O.; Josefonvics, J. and Goasdoue, N. (1999). Degradation of alga (Ascophyllum nodosum) fucoidan by an enzymatic activity contained in digestive glands of the marine mollusk Pecten maximus. Carbohydrate Research, 322:291-297.

Dongowski, G. and Lorenz, A. (1998). Unsatured oligogalacturonic acids are generated by in vitro treatment of pectin with human faecal flora. Carbohydrate Research, 314:237-244.

de Vries, R.P.;Visser, J. and de Graaff, L.H. (1999). CreA modulates the XlnR induced expression on xylose of Aspergillus niger genes involved in xylan degradation. Research in Microbiology, 150:281-285.

De Vries, R.P. (2003). Regulation of Aspergillus genes encoding plant cell wall polysaccharide-degrading encimes; relevance for industrialproduction. Applied Microbiology Biotechnology, 61:10-20

Dubois, M.; Gilles, K.A.; Hamilton, J.; Krobers, P.A. and Smith, F. (1956). Colorimetric method for determination of sugars and related substances. Analytical Chemistry, 28:350356.

Donaghy, J.A. and McKay, A. M. (1994). Pectin extraction from citrus peel by polygalacturonase produced on whey. Bioresource Technology, 47:25-28.

Englyst, H.N. and Cummings, J.H. (1988). Improved method of measurement of dietary as a non-starch polysaccharides in plant foods. Journal AOAC, 71:808-814.

Flipphi, M.J.A.; Visser, J.; van der Veen, P. and de Graaff, L.H. (1994). Arabinase gene expression in Aspergillus niger: indications for coordinated regulation. Microbiology, 140:2673-2682.

Gielkens, M.C.C.; Dekkers, E.; Visser, J. and Graaf, L.H. (1999). Two cellobiohydrolaseencoding genes from Aspergillus niger require D-xylose and the xylanolytic transcriptinal activator XlnR for their expression. Applied Environmental Microbiology, 64:4340-4345.

Hara, T.; Fujio, Y. and Ueda, S.. (1982). Production of polygalacturonase by Aspergillus niger cultured in media containing mandarin orange peels. Nippon Shokuhin Kogyo Gakkaishi, 29:538-42

Hellí, P.; Ros, J.M. and Laencina, J. (2001). Changes in high and low molecular weight carbohydrates during Rhizopus nigricans cultivation on lemon peel. Carbohydrate Polymers, 45:169-174.

Herber D.; Phipps P. and Strange P. (1971). Chemical analysis of microbial cells. In: Methods in Microbiology. J. Norris and D. Ribbons (Eds.). Vol. 5B. London: Academic Press. pp:210-344. 
Hugouvieux-Cotte-Pattat, N.; Condemine, G.; Nasser, W. and Reverchon, S. (1996). Regulation of pectinolysis in Erwinia chrysanthemi. Annual Review Microbiology, 50:213257.

Klavons, J.A.; Bennet, R.D. (1986) Determination of methanol using alcohol oxidase and its application to methyl ester content of pectins. J. Agric. Food Chem., 34:597-599.

Kunzek, H.; Kabbert, R. and Gloyna, D. (1999). Aspects of material science in food processing: changes in plant cell walls of fruits and vegetables. Z Lebensm Unters Forsch A, 208:233-250.

McKeon, T.A. (1988). Activity strain for polygalacturonase. Journal of Chromatography, 455:376-381.

Lenney, J.F. (1975). Three yeast proteins that specifically inhibit yeast proteases A, B and C. Journal of Bacteriology, 122:1265-1273.

Lowry, O.H.; Rosebrough, N.J.; Farr, A.L. and Randall, R.J. (1951). Protein measurement with the Folin phenol reagent. Journal Biological Chemistry, 193:265-75.

Maldonado, M.C.; Navarro, A. and Callieri, D.A.S. (1986). Production of pectinases by Aspergillus sp. using different pretreated lemon peel as the carbon source. Biotechnology Letters, 8:501-504.

Maldonado, M. C.and A. M. Strasser De Saad (1998). Production of pectinesterase and polygalacturonase by Aspergillus niger in submerged and solid state systems. Journal of Industrial Microbiology \& Biotechnology, 20:34-38.

Miller, G.L. (1959). Use of dinitrosalicylic acid reagent for determination of reducing sugar. Analytical Chemistry, 31:426-428.

Mutter, M. \{1997). New rhamnogalacturonan degrading enzymes from Aspergillus aculeatus. Doctoral Thesis. Wageningen Agricultural University. pp:1137.

Nandi, B. (1978). Glucosamine analysis of fungus-infected wheat as method to determine the effect of antifungal compounds in grain preservation. Cereal Chemistry, 55:121-126.

Norouzian, D.; Hosseinzadeh, A.; Inanlou, Nouri, D.and Moazami, N.P (2000). roduction and partial purification of naringinase by Penicillium decumbens PTCC 5248. World Journal of Microbiology \& Biotechnology, 16:471-473.

Ogasawara, H.; Takahashi, K.; Iitsuka, K.; Ito, K. and Ishikawa, T. (1991). Contribution of hemicellulase in shochu koji to the resolution of barley in shachu mash. J. Brew. Soc. Japan, 86:304-307. 
Pedroza-Islas, R.; Aguilar-Esperanza, E. y Vernon-Carter, E.J. (1995). Extraction of pectin from tejocote (Crataegus mexicana) by acid hydrolysis and by ion exchange resins. Rev. Esp. Cienc. Tecnol. Aliment., 35:151-158.

Pilosof, A.M. y Bartholomai, G. (2000). Caracterización funcional y estructural de proteínas. Eudeba-CYTED, Buenos Aires, Argentina. pp:1-181.

Puri, M. and Banerjee, U.C. (2000). Production, purification, and characterization of the debittering enzyme naringinase. Biotechnology Advances, 18:207-217.

Riou, C.; Freyssinet, G. and Fevre, M. (1991). Production of cell wall-degrading enzymes by the phytophatogenic fungus Sclerotinia sclerotium. Applied and Environmental Microbiology, 57:1478-1484.

Royo-Iranzo, J.; Miralles, C. and Claramunt, P. (1975). Preparación de corteza seca de naranja para la obtención de pectina a partir de variedades cultivadas en España. Rendimiento y calidad del producto. Rev. Agroquím. Tecnol. Alim. 15:539-546.

Ruijter, G.J.G. and Visser, J. (1997) Carbon repression in Aspergilli (minireview). FEMS. Microbiol. Lett. 151:103-114.

Sabir, M.A.; Sosulski, F.W. and Campbell, S.J. (1976). Polymetaphosphate and oxalate extraction of sunflower pectins. J. Agric. Food Chem., 24:348-350.

Seaman, J.F., Moore, W.E., Mitchell, R.L. and Millett, M.A. (1954). Techniques for the determination of pulp constituents by quantitative paper chromatography. Tappi. 37 : 336343.

Saha, B.C. (2000). $\alpha$-L-arabinofuranosidases: biochemistry, molecular biology and application in biotechnology. Biotechnology Advances, 18:403-423.

Samoshina, N.M.; Yugova, L.V.; Gross, P.H.; Bravova, G.B.; Shishkova, A.A. and Samoshin, V.V. (2000). Partial purification and characterization of glycosidases from Aspergillus oryzae and Penicillium canescens. Book of Abstracts, 219th ACS National Meeting, San Francisco, CA, March 26-30, 2000, BIOL-160 American Chemical Society, Washington, D.C.

Smith, B.J. SDS polyacrylamide gel electrophoresis of proteins. In: Methods in Molecular Biology. Walker, J.M., editor. Vol 1 Proteins. Clifton, New Jersey: The Humana Press Inc, 1984. p.41-56.

Solis-Pereira, Sara; Favela-Torres, Ernesto; Viniegra-Gonzalez, Gustavo; Gutierrez-Rojas, Mariano (1993). Effects of different carbon sources on the synthesis of pectinase by Aspergillus niger in submerged and solid state fermentations. Applied Microbiology and Biotechnology, 39:36-41. 
Sudo, S.; Ishikawa, T.; Takayasu-Sakamoto, T.; Sato, K. and Oba T. (1993). Characteristics of acid stable $\alpha$-amylase production by submerged culture of Aspergillus kawachii. Journal Fermentation Bioengineering, 76:105-110.

Tanaka, K. and Sorai, S. (1970). Hydrolysis of fucoidan by abalone liver $\alpha$-L-fucosidase. FEBS Letters, 9:45-48.

Thibault, J.F. (1979). Automatisation du dosage des substances pectiques par la méthode au méta-hydroxydiphényl. Food Science Technology, 12:247-251.

Toyama H. and N. Toyama, N. (1997). Isolation of acid hyper-producing strains from hiperpolyploids of Aspergillus kawachii. Microbios, 90:23-32.

Trejo-Aguilar, B.A.; Visser, J. And Aguilar G. (1996). Pectinase secretion by AspergillusFP180 and Aspergills niger N-402 under stress induced by the $\mathrm{pH}$ of culture medium. In: Pectin and Pectinases. J. Visser and A.G.J. Voragen (Eds.). Elsevier Science B.V. The Netherlands. Pp:915-920.

van Peij, N.N.M.E.; Gielkens, M.M.C.; de Vries, R.P. and de Graaff, L.H. (1998). The transcripcional regulator $\mathrm{X} \ln \mathrm{R}$ regulates both xylanolytic and endoglucanase gene expression in Aspergillus niger. Appl. Environ. Microbiol. 65: 4340-4345.

Vita, C.E.; Contreras-Esquivel, J.C.; and Voget, CE. (2001). Pectolytic enzymes of Aspergillus kawachii. Biocell, 25 (Supplement):84.

Villariño, C.; Giorgio, J.F.; Hours, R.A. and Cascone, O. (1993). Spectrophotometric method for fungal pectinesterse activity determination. Food Science and Technology, 26:107-110.

Wubben, J.P.; ten Have, A.; van Kan, J.A.L. and Visser, J. (2000). Regulation of endopolygalacturonase gene expression in Botrytis cinerea by galacturonic acid, ambient $\mathrm{pH}$ and carbon catabolite repression. Current Genetics, 37:152-157. 


\title{
3. Purificación y caracterización parcial de una poligalacturonasa ácida de Aspergillus kawachii
}

\begin{abstract}
Resumen
Se purificó una endo-poligalacturonasa (PGI) de Aspergillus kawachii IFO 4308 hasta homogeneidad, a juzgar por SDS-PAGE, a partir de un cultivo en medio líquido utilizando glucosa como fuente de carbono. El peso molecular de PGI fue de $60 \pm 1.15 \mathrm{kDa}$ mientras que el estimado por tamiz molecular (Sephacryl S-100) fue de $40 \pm 1.04 \mathrm{kDa}$. El IEF de la proteína purificada mostró la presencia casi exclusiva de una banda activa con pI de 3.5-3.6. PGI se adsorbió a Concavalina A lo cual sugiere que es una glicoproteína. PGI hidroliza sustratos solubles e insolubles a $\mathrm{pH} \leq 3.0$ y es prácticamente inactiva a $\mathrm{pH} 5.0$, propiedad que la diferencia de la mayoría de las PGasas fúngicas conocidas. La estabilidad térmica de la enzima a bajos valores de $\mathrm{pH}$ parece dependió de la presencia de sustancias estabilizantes como proteínas (albúmina), polisacáridos, azúcares simples (sacarosa) y pectina. La enzima degrada ácido poligalacturónico (APG) y pectina por un mecanismo endo y muestra preferencia por sustratos de bajo grado de esterificación. El análisis por cromatografía de capa fina de los productos de hidrólisis de APG, sugiere que la enzima cataliza la hidrólisis con cierto grado de múltiple ataque. La secuencia N-terminal de PGI fue la siguiente: S-T-C-T-FT-D-A-A-T-A-S-E-S-K.
\end{abstract}

\subsection{Introducción}

El interés en las poligalacturonasas (PGasas), como de otras pectinasas, se ha visto incrementado en los últimos años debido al descubrimiento de nuevas enzimas, los avances en el conocimiento de su modo de acción, de su rol en diversos procesos fisiológicos relacionados con la interacción planta-patógeno y la maduración de frutos y a nuevas aplicaciones, como la preparación de pectinas modificadas y oligosacáridos, biorefinado, desgomado de fibras y extracción de pectina de diferentes fuentes (Capítulo 1). Las PGasas fúngicas, en particular las del género Aspergillus, han sido la mas extensamente estudiadas, en parte debido al empleo de este microorganismo en la producción comercial de muchas de estas enzimas. Una razón para ello es que varias especies de Aspergillus son consideradas GRAS (General Recognize As Safe) y por lo tanto sus enzimas son aceptadas como insumos en procesos de producción de bebidas y alimentos. En la Tabla 3.1 se muestran las características físico-químicas de algunas PGasas del género Aspergillus. 
Tabla 3.1. Propiedades físico-químicas de algunas poligalacturonasas de Aspergillus sp.

\begin{tabular}{|c|c|c|c|c|c|c|c|}
\hline Especie & $\begin{array}{c}\text { Enzima } \\
.\end{array}$ & Tipo & $\begin{array}{c}\text { PM } \\
\text { (kDa) }\end{array}$ & $\begin{array}{c}\text { pH } \\
\text { óptimo }\end{array}$ & pI & $\begin{array}{l}\text { Temp } \\
\text { óptima }\end{array}$ & Referencia \\
\hline \multirow[t]{3}{*}{ A. awamori } & PPasa-AS & - & 52 & - & 3.7 & 50 & Nagai et al. [2000] \\
\hline & PGasa-X2 & Endo & 41 & 5.0 & 6.1 & 40 & Nagai et al. [2000] \\
\hline & PGasa-X2- & Endo & 41 & 5.0 & 6.1 & 40 & “ \\
\hline \multirow[t]{3}{*}{ A.carbonarous } & PG I & - & 61 & 4.0 & - & 55 & Devi and Rao [1996] \\
\hline & PG II & - & 42 & 4.1 & - & 50 & “ \\
\hline & PG III & - & 47 & 4.3 & - & 55 & “ \\
\hline A. japonicus & PG & Endo & 35.5 & 4.5 & - & - & Ishii and Yokotsuka [1972] \\
\hline \multirow{3}{*}{ A. kawachii } & PGasa-A1 & - & 43 & 4 & - & 50 & Kojima et al. [1999] \\
\hline & PGasa-A2 & - & 80 & 3 & - & 60 & “ \\
\hline & PGasa-B & - & 71 & 5 & - & 60 & “ \\
\hline \multirow[t]{4}{*}{ A. niger } & PG I & Endo & 46 & 4.5 & 5.6 & 55 & Hara et al. [1986] \\
\hline & PG II & Endo & 35 & 4.5 & 6.5 & 55 & “ \\
\hline & PG I & Exo & 66 & 3.8 & 5.6 & 60 & “ \\
\hline & PG II & Exo & 63 & 4.5 & 5.8 & 60 & “ \\
\hline A. niger* & PG & Endo & - & 4.1 & - & 45 & Thibault [1978] \\
\hline A. niger** & PG & Endo & - & 4.5 & - & 45 & Labavitch and Rae [1977] \\
\hline \multirow[t]{3}{*}{ A. niger } & PG I & Exo & - & 5.0 & - & - & Behere et al. [1993] \\
\hline & PG II & Exo & - & 5.0 & - & - & “ \\
\hline & PG III & Endo & - & 5.0 & - & - & “ \\
\hline \multirow[t]{6}{*}{ A. niger*** } & PG I & Endo & 55 & 4.9 & $3.2-$ & - & Kester and Visser [1990] \\
\hline & PG II & Endo & 38 & 4.8 & $4.6-$ & - & “ \\
\hline & PG III A & Endo & 57 & 4.3 & 3.3 & - & “ \\
\hline & PG III B & Endo & 57 & 4.5 & 3.3 & - & “ \\
\hline & PG IV & Endo & 59 & 4.8 & 3.7 & - & “ \\
\hline & PG I & Exo & & 4.0 & & - & “ \\
\hline A. ustus & & Endo & 36 & & 8.3 & - & Rao et al. [1996] \\
\hline
\end{tabular}

* Pectinasa (Rapidase USK 5933; Gist-brocades); ** Pectinasa (ICN Nutritional biochemicals);

*** Pectinasa (Rapidase K2B 078; Gist-brocades). PM: Peso molecular.

El pH es una de las variables fundamentales que controlan la estabilidad y actividad de las enzimas. Si bien se han descriptos PGasas fúngicas activas en medio alcalino [Hoondal et al., 2002], la mayoría de estas enzimas son activas bajo condiciones de acidez moderada (rango de pH típico 3.0-6.0). Los reportes de PGasas activas en un rango de $\mathrm{pH}$ inferior a 3.0 son muy pocos. Kaji and Okada [1969] reportaron una PGasa inusual producida por el hongo Corticium rolfsii con actividad significativa sobre varios sustratos pécticos a $\mathrm{pH}$ 1.5-2.0. Una enzima con actividad óptima en protopectina a pH 2.3 fue descripta en un mutante de A. niger [Leuchtenberger et al., 1992] y más recientemente una endo-PGasa (PPasa-AS) con actividad óptima sobre protopectina a pH 2.0 fue purificada de extractos de cultivos sólidos en afrecho de trigo de A. awamori IFO 4033 [Nagai et al., 2000]. A. kawachii produce en forma 
parcialmente constitutiva pectinasas activas a pH 2.0-3.0 (medidas como actividad PGasa o PPasa) con capacidad para solubilizar sustancias pécticas altamente polimerizadas de cáscaras de limón en un tiempo razonable y con aceptable rendimiento (Contreras-Esquivel et al., 1999, Capítulo 2 de la presente Tesis). Estudios posteriores demostraron que en el medio glucosa esta actividad pectolítica es llevada a cabo por una endo-PGasa. En este capítulo se describe la purificación y parcial caracterización de esta enzima.

\subsection{Materiales y métodos}

\subsubsection{Reactivos químicos y buffers}

Pectina cítrica (85 \% de AGA, grado de metoxilación GM, 53 \%), APG (sal sódica, 90 \% de AGA), ácido trigalacturónico (ATG), ácido galacturónico monohidrato (AGA), rojo de rutenio y membranas de celulosa para diálisis (corte $12400 \mathrm{Da}$ ) fueron obtenidos de Sigma. Sepharose Q Fast Flow, Sephacryl S-100, Concavalina A-Sepharose 4B (ConA-Sepharose), columnas PD-10, patrones de proteína de bajo peso molecular (14.4 a $94 \mathrm{kDa})$ para electroforesis, anfolitos para isoelectroenfoque (IEF) en el rango pH 2.5-5.0 (Pharmalyte) y patrones de bajo pI fueron obtenidos de Pharmacia Biotech. Como fuente de PGasa purificada de A. niger se utilizó el producto de Megazyme. La actividad volumétrica de la muestra fue 9000 U/ml (APG, pH 4.5) y la específica 4100 U/mg proteína. Para los ensayos, el producto se disolvió en BCP pH 5.0 (300-400 U/ml), y se pasó por una columna PD10 equilibrada con buffer. La muestra recolectada se conservó refrigerada.

La composición del BCP fue la siguiente: ácido cítrico $50 \mathrm{mM}$, fosfato disódico $25 \mathrm{mM}$, ajustado a pH 5.5 con $\mathrm{NaOH}$. La composición del buffer AcONa fue ácido acético $50 \mathrm{mM}$ ajustado a pH 5.5 con $\mathrm{NaOH}$. Cuando fue requerido, los buffers se diluyeron y/o su pH se modificaron al valor deseado mediante el agregado de HCl. La dilución del buffer se expresa con una fracción (i.e. BCP 1/2 indica buffer BCP diluido a la mitad).

\subsubsection{Microorganismo y condiciones de cultivo}

Se utilizó la cepa de A. kawachii IFO 4308. La composición del medio glucosa/triptona, y el desarrollo de los cultivos en frascos agitados se describió en el Capítulo 2. Los cultivos fueron incubados hasta consumo total de la glucosa (30 35 h). La separación de micelio de la fase líquida fue llevada a cabo filtrando el medio a través de tela muselina. El filtrado obtenido fue centrifugado (5000 g x 20 minutos) y el sobrenadante (medio centrifugado, MC) congelado en recipientes de plástico $(500 \mathrm{ml})$ a $-20^{\circ} \mathrm{C}$. Cuando se lo requirió, se descongeló en un baño a $37^{\circ} \mathrm{C}$. 


\subsubsection{Purificación de la poligalacturonasa ácida}

Para la purificación de la PGasa ácida, el pH de MC se ajustó a 3.0 y se filtró tres veces (reciclando el permeado) a través de prefiltros de fibra de vidrio (tipo G25, $47 \mathrm{~mm}, 1.0 \mu \mathrm{m}$ de tamaño de poro, OSMONICS) empleando un soporte de filtro de polisulfona. El proceso de filtración se llevó a cabo con ayuda de vacío a una velocidad de filtración de 20-25 ml por minuto a $20-25^{\circ} \mathrm{C}$. Se filtraron $300 \mathrm{ml}$ de $\mathrm{MC}$ por cada filtro. Los permeados obtenidos se mezclaron y constituyeron el material de partida para la purificación de la enzima. La concentración del permeado se realizó por evaporación a presión reducida con un rotavapor a escala banco (Büchi). El matraz bola fue agitado a 30 vueltas por minuto. La temperatura del baño fue $40{ }^{\circ} \mathrm{C}$ y el vacío se obtuvo mediante una bomba con trampa de agua. El proceso de concentración se evaluó a pH 3.0 y 6.0 (ajustados con $\mathrm{H}_{3} \mathrm{PO}_{4}$ o $\mathrm{NaOH}$ ). A partir del concentrado, la enzima fue purificada en un proceso de tres etapas: precipitación con solventes, cromatografía de intercambio aniónica (CIAN) y cromatografía de permeación por gel o tamiz molecular (CTM). El proceso global incluyó también varias etapas de diálisis, las cuales se efectuaron durante 12 h a $5{ }^{\circ} \mathrm{C}$ bajo agitación con una relación solución/buffer 1:100. El esquema general del proceso de purificación se muestra en la Figura 3.1. La muestra final liofilizada se conservó en heladera. Cuando se la requirió, se disolvió en agua deionizada a una concentración equivalente a 130 $\mu$ g proteína/ml (solución stock, SE). El pH de SE fue 5.0 debido a la presencia de buffer BCP en el liofilizado. La actividad de SE se mantuvo estable al menos 15 días a $5{ }^{\circ} \mathrm{C}$.

\subsubsection{Ensayos de actividad enzimática}

Actividad PPasa: se siguió la técnica descripta en el Capítulo 2.

Actividad PGasa y actividad sobre pectina: se determinó midiendo el incremento de reductores con el reactivo DNS [Miller, 1959]. A menos que se indique lo contrario, la mezcla de reacción final consistió de $1.45 \mathrm{ml}$ de solución de sustrato (0.5 \% de APG o pectina en BCP al pH seleccionado) y $50 \mu \mathrm{l}$ de enzima. A diversos intervalos de tiempo, se removieron $166 \mu$ l de mezcla de reacción y se mezclaron con igual volumen de solución alcalina $\left(\mathrm{Na}_{2} \mathrm{CO}_{3}\right.$ $2.4 \%, \mathrm{NaHCO}_{3} 1.6 \%$, sal de Rochelle $1.2 \%$ ) enfriada en baño de hielo. Luego se agregó 1.0 $\mathrm{ml}$ de reactivo DNS y la mezcla se calentó 10 minutos a $100{ }^{\circ} \mathrm{C}$. Una vez fría, se centrifugó a $10,000 \mathrm{~g} \times 5 \mathrm{~min}$ en una microcentrífuga (para eliminar cualquier material suspendido) y la absorbancia del sobrenadante se determinó a 550 nm. Para la curva de calibración se empleó ácido galacturónico como patrón disuelto en buffer (100-500 ppm). Las unidades de actividad fueron calculadas de la pendiente de la recta de azúcares reductores y tiempo de reacción, 
generalmente 10 a 60 min para 0.5-10 U/ml en la muestra de enzima. Una unidad de actividad enzimática (PPasa, PGasa) se define como la cantidad de enzima que produce un $\mu$ mol de azúcar reductor como ácido galacturónico por minuto. Los ensayos de viscosidad fueron realizados en un viscosímetro Ostwald con $7 \mathrm{ml}$ de mezcla de reacción. Los cambios en la viscosidad del sustrato fueron expresados como valores relativos; la viscosidad relativa se define como porcentaje: $\left.(\%)=\left(\mathrm{t}_{\mathrm{s}}-\mathrm{t}_{\mathrm{b}}\right) / \mathrm{t}_{\mathrm{so}}-\mathrm{t}_{\mathrm{b}}\right) 100$ donde $\mathrm{t}_{\mathrm{so}} \mathrm{y} \mathrm{t}_{\mathrm{s}}$ son los tiempos de flujos del sustrato a tiempo cero y a cualquier tiempo de reacción, respectivamente. El t $t_{b}$ es el tiempo de flujo del buffer. El tiempo de reacción fue tomado de acuerdo a la siguiente ecuación: $\mathrm{t}_{\mathrm{r}}=$ $t_{0}+1 / 2 t_{f}$ donde $t_{r}=$ tiempo de reacción y $t_{0}=$ tiempo de reacción en el momento que el menisco pasa por la marca superior del viscosímetro, $\mathrm{y} \mathrm{t}_{\mathrm{f}}=$ tiempo total del flujo.

\begin{tabular}{|c|}
\hline $\begin{array}{l}\text { Cultivo filtrado por filtro de fibra de vidrio } \\
\qquad 3300 \mathrm{ml}\end{array}$ \\
\hline$\nabla$ \\
\hline $\begin{array}{l}\text { Evaporación a presión reducida } \\
\qquad 0^{\circ} \mathrm{C} \times 8 \mathrm{~h} \\
\text { pH inicial: } 3.0, \mathrm{pH} \text { final: } 2.78 \\
\text { Volumen final concentrado } 410 \mathrm{ml}\end{array}$ \\
\hline$\downarrow$ \\
\hline $\begin{array}{c}\text { Precipitación con acetona } \\
1 \text { volumen concentrado }+2.5 \text { volúmenes de acetona } \\
3 \text { h en baño de hielo y agitación suave } \\
\text { Centrifugación } 7000 \mathrm{~g} \times 20 \text { minutos } \\
\text { Resuspensión del precipitado en } 30 \mathrm{ml} \text { de BCP (1/4) pH } 5.0 \\
\text { Diálisis durante toda la noche contra buffer } \\
\text { Volumen final: } 40 \mathrm{ml}\end{array}$ \\
\hline$\nabla$ \\
\hline $\begin{array}{c}\text { Sepharose Q (XK 26/20, } 60 \mathrm{ml} \text { gel) } \\
\text { buffer de equilibrio: BCP (1/4) pH 5.0 } \\
\text { Lavado: } 150 \text { ml buffer seguido de } 150 \mathrm{ml} \text { de NaCl 0.3 M en buffer } \\
\text { Elución: Gradiente de NaCl 0.3 M a 0.5 M en buffer } \\
\text { Caudal: } 3 \text { ml/min; Volumen de fracción: } 5 \mathrm{ml} \\
\text { Diálisis durante toda la noche contra buffer BCP (1/4) pH } 5.0 \\
\text { Liofilización } \\
\text { Volumen final } 1.0 \mathrm{ml}\end{array}$ \\
\hline$\downarrow$ \\
\hline $\begin{array}{c}\text { Sephacryl S-100 (XK 16/70, } 100 \mathrm{ml} \text { gel) } \\
\text { buffer de equilibrio: BCP (1/4) pH 5.0. } \\
\text { Velocidad de flujo: } 0.5 \mathrm{ml} / \mathrm{min} ; \text { Volumen de fracción: } 2 \mathrm{ml} \\
\text { Diálisis durante toda la noche contra BCP (1/10) pH } 5.0 \\
\text { Liofilización }\end{array}$ \\
\hline
\end{tabular}

Figura 3.1. Esquema de la purificación de la PGasa ácida de A. kawachii IFO 4308. 


\subsubsection{Propiedades de la enzima}

3.2.5.1. Relación pH-actividad. El efecto del pH en la actividad fue evaluado sobre APG, pectina cítrica y protopectina usando BCP en el rango de pH 2.0 a 5.5 siguiendo el protocolo indicado en 3.2.5. La dilución de la SE en la mezcla de reacción varió entre 500 y 5000 veces dependiendo del sustrato usado. Debido a que la solubilidad del APG disminuye marcadamente a $\mathrm{pH}<$ de 2.5, las soluciones de este sustrato a $\mathrm{pH} 2.0$ muestran un aspecto turbio debido a la precipitación del polímero. Para estandarizar las condiciones de reacción, el APG a pH 2.0 se empleó luego de un día de preparación. La fracción soluble luego de centrifugar a $15000 \mathrm{~g}$ x 2 min fué $14 \%$.

3.2.5.2. Estabilidad térmica. Para el estudio de la estabilidad térmica, la SE se diluyó 1:200 en BCP (rango de pH 2.0 a 5.5, volumen final 100 l) y se incubó 30 minutos a la temperatura seleccionada. Transcurido dicho tiempo, las muestras fueron rápidamente enfriadas en baño de hielo, mezcladas con $400 \mu \mathrm{l}$ de BCP, pH 4.5 e incubadas $10 \min$ a $37^{\circ} \mathrm{C}$. La actividad residual fue determinada como se describió en 3.2.5 después de la adición de $500 \mu \mathrm{l}$ de APG al 1\% en BCP, pH 4.5 .

3.2.5.3. Hidrólisis de APG y pectina. La degradación enzimática de APG y pectina cítrica fue evaluada a $37^{\circ} \mathrm{C}$ incubando una solución de sustrato al 1\% en AcONa, pH 4.5 (APG) o pH 2.5 (pectina cítrica). Se empleó AcONa en reemplazo de BCP para evitar interferencias del buffer en la cromatografía en capa fina. Se tomaron muestras a diversos intervalos de tiempo durante un período total de reacción de 24 h. Para inactivar la enzima, las muestras fueron calentadas a $100{ }^{\circ} \mathrm{C}$ por 5 minutos, luego se congelaron a $-20^{\circ} \mathrm{C}$. El curso de la reacción se siguió midiendo el incremento de azúcares reductores (como galácturónico) en la muestra inactivada, por el método del DNS y por Somogyi-Nelson (S-N). El grado de hidrólisis se calculó según la siguiente ecuación:

$\%$ hydrolisis $=($ incremento neto de reductores $) /\left[\left(\mathrm{S} \times \mathrm{R}_{\mathrm{g}} / 176\right)-\mathrm{h}_{0}\right] 100$,

S concentración de sustrato $\mathrm{R}_{\mathrm{g}}$ contenido de AGA del sustrato, 176 peso equivalente de AGA en APG y $h_{o}$ poder reductor del sustrato (tiempo cero de reacción)

3.2.5.4. Análisis de productos de reacción por métodos cromatográficos. Los productos de reacción de la hidrólisis de APG se analizaron por cromatografía en capa fina y CTM. Para pectina se empleó solamente CTM.

Cromatografía en capa fina. Se sembraron $2 \mu$ de muestra inactivada previamente diluida 1:10 con AcONa en placas de aluminio (silica gel $60 \mathrm{~F}_{254}$, Merck). La cromatografía fue realizada dos veces mediante la técnica ascendente empleando un sistema n-butanol: ácido 
acético: agua (9:4:7 v/v/v). Como patrones se utilizaron $2 \mu \mathrm{g}$ de AGA y ATG. Luego de eliminar los solventes, la detección de los productos de reacción se realizó pulverizando sobre la placa una solución al 3 \% de ácido fosfomolíbdico y $10 \%$ de ácido sulfúrico en alcohol etílico. Para desarrollar color las placas fueron calentadas por 5 minutos a $105^{\circ} \mathrm{C}$ [Lojkowska et al., 1995].

Cromatografía de tamiz molecular (CTM). Se empleó una columna Sephacryl S100 (XK 16/70, $100 \mathrm{ml}$ gel). El buffer de equilibrio y elución fue AcONa $50 \mathrm{mM}$, pH 4.0, recomendado por Matsuashi et al. [1992]. El volumen de muestra fue de $1 \mathrm{ml}$, el caudal 30 $\mathrm{ml} / \mathrm{h}$ y el volumen de fracción recolectada $2 \mathrm{ml}$. Las cromatografías se efectuaron a temperatura ambiente. Como marcadores de alto peso molecular $\left(\mathrm{K}_{\mathrm{av}}=0\right)$, se utilizaron APG, RG y azul dextrano y como marcador de bajo peso molecular AGA $\left(K_{a v}=1\right)$. En las fracciones recolectadas se determinó ácido galácturónico por el método del $m$-hidroxidifenilo [Blumenkrantz and Asboe-Hansen, 1972]. El azul dextrano fue evaluado a $624 \mathrm{~nm}$.

3.2.5.5. Parámetros cinéticos sobre APG. Los parámetros cinéticos Vmax y Km fueron determinados a partir de medidas de velocidad inicial empleando APG en concentraciones de 0.01 a $0.5 \mathrm{mg} / \mathrm{ml}$. Para determinar las concentraciones de azúcares reductores se utilizó el método de Somogyi-Nelson debido a su mayor sensibilidad comparado con el DNS. Los parámetros cinéticos fueron estimados usando un algoritmo de regresión no lineal de Leverberg-Marquard.

\subsubsection{Técnicas bioquímicas}

Las etapas cromatográficas fueron realizadas con un equipo FPLC (Pharmacia Biotech). Los análisis mediante SDS-PAGE fueron llevados a cabo en un equipo Mighty Small II Unit (Hoefer SE 260) de acuerdo a Smith [1984]. El isoelectroenfoque (IEF) fue realizado en una unidad de electroforesis (LKB Bromma 2117 Multiphor II) a una temperatura de $10^{\circ} \mathrm{C}$. El gel se preparó con una capa fina de poliacrilamida en el rango ácido de acuerdo a las instrucciones del fabricante. Como buffer catódico se utilizó una solución de ácido sulfúrico 0.1M y como buffer anódico una solución de $\mathrm{NaOH} 0.1 \mathrm{M}$. Se sembraron aproximadamente 3 $\mu$ g de PGasa pura. Para visualizar la actividad PGasa, el gel de IEF se cubrió con un gel fino de agarosa conteniendo 0.5 \% de APG y se incubó 60 min en BCP, pH 2.5, luego se escurrió y sumergió en una solución de rojo rutenio al 0.02 \% en agua. Para la determinación del pI, el gel de isoelectroenfoque se tiñó con plata. 
La glicosidación de la PGasa fue evaluada determinando la adsorción a ConA-Sepharose y por tratamiento enzimático con PNGasa F. Para la adsorción a ConA-Sepharose, se utilizó una columna de $1 \mathrm{ml}$ (columna HR 5/10) lavada sucesivamente con $10 \mathrm{ml}$ de Tris-HCl $0.1 \mathrm{M}$, pH 8.5, 0.5 M NaCl; $10 \mathrm{ml}$ de AcONa 0.1M, pH 5.5, $0.5 \mathrm{M} \mathrm{NaCl}$ conteniendo $\mathrm{MnCl}_{2} 1 \mathrm{mM}$ y $\mathrm{CaCl}_{2} 1 \mathrm{mM}$ y $10 \mathrm{ml}$ de AcONa 0.1M, pH 5.5, NaCl 0.5 M (buffer de equilibrio). Después de aplicar la muestra ( $1 \mathrm{ml}$; conteniendo $1.0 \mu \mathrm{g}$ de proteína), la columna fue lavada con $10 \mathrm{ml}$ de buffer de equilibrio y luego con AcONa $0.1 \mathrm{M}$, pH 5.5 conteniendo $\alpha$-metil-manósido 0.5 M. Se recuperaron fracciones de $1 \mathrm{ml}$ y se determinó en ellas la actividad PGasa a pH 2.5. Para el análisis de N-glicosidación sobre la proteína desnaturalizada, se usó el kit de PNGasa F de acuerdo a las instrucciones dadas por el fabricante (BIORAD). El tiempo de incubación fue de12 h a $37^{\circ} \mathrm{C}$. La concentración final de proteína fue de $10 \mu \mathrm{g} / \mathrm{ml}$. Al término de la incubación, se tomaron muestras de $10 \mu \mathrm{l}$ para evaluar los cambios de peso molecular por SDS-PAGE.

La secuencia N- terminal se efectuó en el LANAIS-PRO (Universidad de Buenos Aires, Facultad de Farmacia y Bioquímica, Buenos Aires, Argentina). El liofilizado final se disolvió en TFA al $0.1 \%$ y se aplicó a una columna de fase reversa (Aquapore, C-4, 30 x $2.1 \mathrm{~mm}$, Brownlee, Perkin Elmer, Inc) acoplada a un equipo de HPLC (modelo 140 Applied Biosystems) con detector de arreglo de diodos. La elución se efectuó mediante un gradiente de acetonitrilo (0-80\%) en TFA al 0.08\%. Se recolectaron fracciones de $200 \mu \mathrm{l}$. La parte central del pico se secuenció en un secuenciador de aminoácidos mediante degradación de Edman (Model 477, Applied Biosystem). La cantidad de proteína secuenciada fue 10 pmoles.

\subsection{Resultados}

\subsubsection{Purificación de la PGasa ácida}

Como material de partida para la purificación de la enzima con actividad PPasa a pH 2.0 y/o actividad PGasa en el rango de pH 2.0-2.5 se empleó el permeado de MC. Los resultados del proceso de purificación mostraron que ambas actividades provienen de la misma proteína. Para simplificar la presentación de los resultados solo se muestran los datos de actividad PGasa a pH 2.5. Para iniciar el proceso de purificación, el permeado se concentró primeramente por evaporación a presión reducida. Una variable importante en la concentración fue el pH. Se encontró una pérdida de actividad del 70 a $80 \%$ cuando se evaporó a pH cercano a la neutralidad. En cambio, a pH 3.0 se recuperó el 90-95\% de la 
actividad. Por lo tanto se adoptó la evaporación a pH 3.0 como etapa primaria de concentración del permeado. Luego de evaporar al vacío, se efectuó una nueva etapa de concentración, esta vez por precipitación. Estas técnicas son en general de baja selectividad, pero eliminan contaminantes de bajo peso molecular. Se ensayó precipitación con sulfato de amonio y con solventes. Los mejores resultados se obtuvieron con solventes, en particular acetona. Las condiciones de precipitación finalmente seleccionadas fueron las siguientes: relación acetona/concentrado: 2.5/1.0, temperatura: $0-2^{\circ} \mathrm{C}$ (baño de hielo, el solvente sé preenfrió en congelador a $-20^{\circ} \mathrm{C}$ y se adicionó al concentrado lentamente bajo agitación), tiempo de contacto: $3 \mathrm{~h}$. Para separar el precipitado, la mezcla se centrifugó a $7000 \mathrm{~g}$ x $20 \mathrm{~min}$ a 2-5 ${ }^{\circ} \mathrm{C}$. El sobrenadante se desechó y el pellet se disolvió en $\mathrm{BCP}$ pH 5.0 a una concentración $10 \times$ respecto del volumen original de concentrado. La disolución del precipitado no fue completa, por lo cual se repitió la centrifugación para obtener un sobrenadante límpido, descartando en este caso el pellet. La recuperación de la actividad enzimática fue del 80-90 \%. El concentrado obtenido se dializó frente al buffer de equilibrio de la cromatografía de intercambio aniónico (CIAN).

Las condiciones de separación de la CIAN se establecieron en ensayos preliminares usando minicolumnas. A pH 5.0 la PGasa ácida se adsorbió fuertemente a la matriz catiónica, mientras que la mayoría de las proteínas contaminantes fueron eliminadas en la etapa de lavado de la columna. El lavado se efectuó con buffer y con buffer conteniendo 0.3 M de $\mathrm{NaCl}$ para incrementar la eficiencia de remoción de contaminantes previo a la elución de la PGasa ácida. La elución se llevó a cabo con un gradiente de $\mathrm{NaCl}$ en el rango 0.3-0.5 M, obteniéndose un pico simétrico de actividad a una concentración $0.42 \mathrm{M}$ de $\mathrm{NaCl}$ (Figura 3.2). A mayor fuerza iónica eluyeron sustancias coloreadas. Esta etapa de alta resolución fue sumamente efectiva para purificar la PGasa, obteniéndose una solución de enzima prácticamente pura. Las fracciones activas correspondientes al 80-90 \% de la actividad recolectada (se descartaron las fracciones del extremo del pico) se juntaron y dializaron. El dializado finalmente se liofilizó para concentrar. Las pérdidas de actividad en las operaciones de la CIAN fueron del orden del 15-30 \%.

La última etapa de la purificación consistió en una cromatografía por tamiz molecular para el pulido final que sirvió además para estimar el peso molecular de la proteína. Esta etapa permitió eliminar compuestos de bajo peso molecular que absorben a $280 \mathrm{~nm}$ pero no reaccionan con el reactivo de Lowry (datos no mostrados). Al igual que en la CIAN, se observó un pico simétrico de actividad PGasa (figura no mostrada). Las fracciones activas se juntaron y dializaron toda la noche. El dializado se distribuyó en frasquitos de vidrio y 
liofilizó para su conservación. Se obtuvieron $460 \mu$ g de proteína purificada de $3300 \mathrm{ml}$ de cultivo lo que representó menos del $0.1 \%$ de la proteína total originalmente presente en el medio. El rendimiento final en términos de actividad enzimática fué del 40 \%. La PGasa ácida resultó muy tolerante a los procesos de congelamiento y liofilización. Los medios de cultivo congelados mantuvieron la actividad enzimática al menos durante un año. Las soluciones buffer de la proteína purificada fueron también muy estables bajo condiciones de refrigeración. Estas propiedades son muy importantes para un futuro cambio de escala del proceso de purificación y el uso de la enzima. En la Tabla 3.2 se resumen los datos de la purificación de la PGasa ácida.

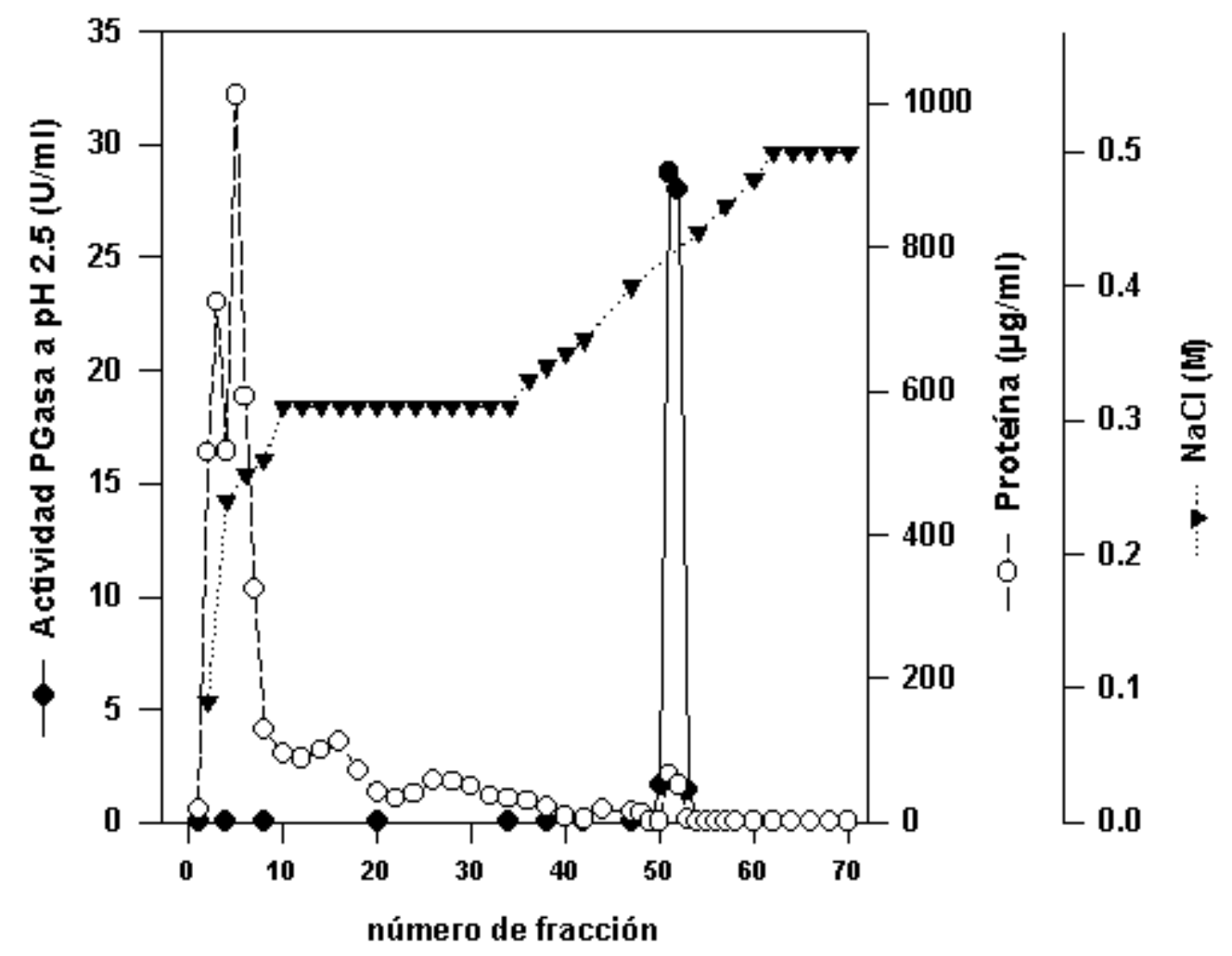

Figura 3.2. Perfil de elución de la PGasa ácida de A. kawachii en la cromatografía de intercambio aniónico (Sepharose Q).

Columna: XK 26/20, $60 \mathrm{ml}$ gel. Lavado: $150 \mathrm{ml}$ de buffer seguido de $150 \mathrm{ml}$ de buffer $+0.3 \mathrm{M}$ de $\mathrm{NaCl}$. Elución: gradiente de $\mathrm{NaCl} 0.3$ a $0.5 \mathrm{M}$ en buffer. Caudal: $3 \mathrm{ml} / \mathrm{min}$, Volumen de fracción: 5 ml. Actividad PGasa: 0.5 \% APG en BCP, pH 2.5. 
Tabla 3.2. Resumen de la purificación de la PGasa ácida de A. kawachii.

\begin{tabular}{lccccc}
\hline Etapa de purificación & $\begin{array}{c}\text { Volumen } \\
(\mathbf{m l})\end{array}$ & $\begin{array}{c}\text { Proteína total } \\
\mathbf{( m g )}\end{array}$ & $\begin{array}{c}\text { Actividad } \\
\text { específica } \\
\text { (U/mg)* }\end{array}$ & $\begin{array}{c}\text { Recuperación } \\
\mathbf{( \% )}\end{array}$ & $\begin{array}{c}\text { Factor de } \\
\text { purificación }\end{array}$ \\
\hline CM (permeado) & 3300 & 560 & 1.11 & 100 & - \\
$\begin{array}{l}\text { Concentración a presión } \\
\text { reducida }\end{array}$ & 410 & 520 & 1.03 & 85 & 1 \\
$\begin{array}{l}\text { Precipitación con acetona/ } \\
\text { diálisis }\end{array}$ & 40 & 108 & 4.62 & 82 & 4.5 \\
$\begin{array}{l}\text { Sepharose Q/ diálisis y } \\
\text { liofilización }\end{array}$ & 1 & 0.65 & 483 & 50 & 470 \\
Sephacryl S100 & 8 & 0.46 & 430 & 40 & - \\
\hline
\end{tabular}

*Actividad medida con 0.5 \% APG en BCP, pH 2.5

\subsubsection{Caracterización de la enzima}

La muestra proveniente del proceso de filtración por gel presentó una sola banda cuando fue analizado por SDS-PAGE (Figura 3.3A). El peso molecular estimado por este método fue $60 \pm 1.15 \mathrm{kDa}$, mientras que el estimado por filtración en gel (Sephacryl S-100) fue $40 \pm 1.04$ kDa. En el IEF (Figura 3.3B) se observa la presencia de una banda grande (pI 3.5-3.6) y una banda muy poco perceptible (pI 3.7), las cuales mostraron actividad PGasa a pH 2.5 pero no actividad a pH 5.0, confirmando que se tratan de PGasas ácidas. El origen de la banda apenas perceptible no se determinó. Otra banda muy pequeña con pI 3.8, no mostró actividad PGasa. Del SDS-PAGE y el IEF podemos concluir que el producto final de la purificación es prácticamente homogéneo. La enzima purificada fue denominada tentativamente PGI de acuerdo con la práctica de designar con números romanos a las múltiples isoformas de una proteína con relación a su pI, en este caso tendríamos la PGasa con menor pI.

La mayoría de las PGasas fúngicas son glicosiladas [Stratilova et al., 1996]. La posible glicosilación de PGI fue establecida determinando la propiedad de adsorción a ConASepharose. Como control positivo se utilizó la endo-PGasa de A. niger. Se observó que efectivamente PGI se adsorbe a la matriz de afinidad. Aproximadamente el 50 \% de la actividad aplicada a la columna se recuperó durante la elución con $\alpha$-metilmanósido. En cambio no se detectó actividad en el buffer de lavado. Estos resultados sugieren que PGI es efectivamente una glicoproteína. En las PGasas fúngicas la glicosidación predominante corresponde a uniones $\mathrm{N}$-glicosídicas. La presencia de esta unión puede detectarse mediante el tratamiento con N-glicosidasa F que hidroliza la unión glicosídica y da lugar a una proteína con mayor movilidad electroforética que su contraparte glicosilada [Raab, 1992]. Cuando el 
test se aplicó a PGI, el resultado fue negativo es decir no se observó un cambio significativo en el patrón electroforético de la proteína tratada con N-glicosidasa F respecto del control sin tratar. Una explicación de este resultado no es directa y se requieren nuevos estudios para explicar la falta de efecto de la N-glicosidasa sobre PGI.

A

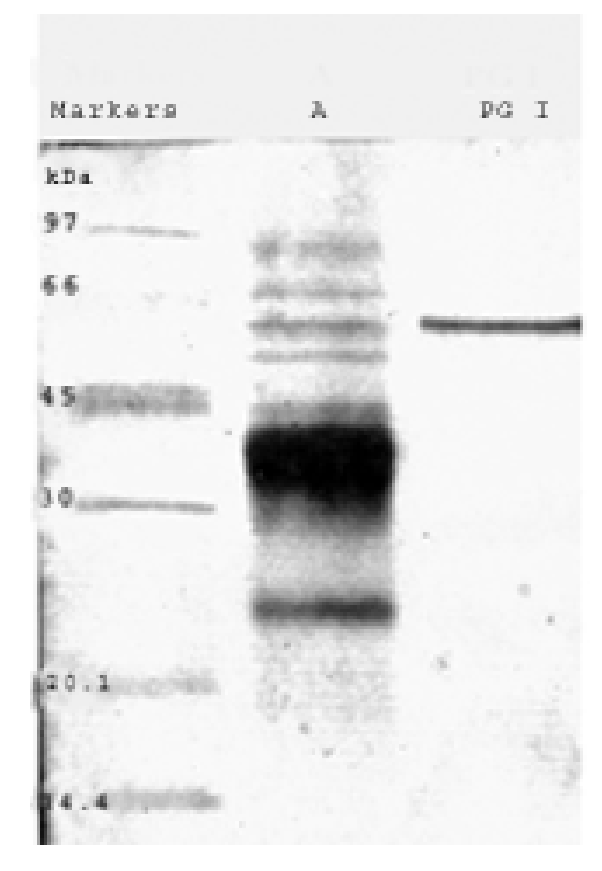

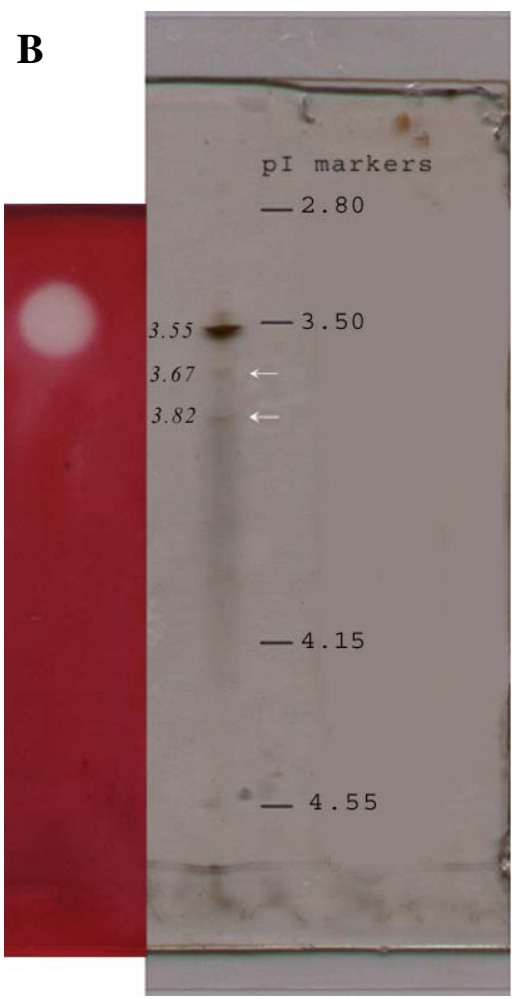

Figura 3.3 SDS-PAGE e IEF de la PGasa ácida de A. kawachii.

A SDS-PAGE Línea 1: Patrones de peso molecular, Línea 2: muestra dializada de la concentración por evaporación a presión reducida (A: siembra: $12 \mu \mathrm{g}$ proteína total); 3) PGI Sephacryl S-100 (siembra: $1.2 \mu$ g proteína). El gel se tiñó con plata.

B IEF Línea 1) Patrones de pI, 2) PGI Sephacryl S-100 (siembra: $3.0 \mu$ g proteína). Para la visualización de la actividad PGasa, el IEF se cubrió con un gel de agarosa conteniendo $0.5 \%$ de APG y se incubó 60 min en BCP, pH 2.5. Luego se tiñó con rojo de rutenio $(0.02 \%$ en agua). Para la determinación del pI, el IEF se tiñó con plata.

La secuencia N-terminal de la proteína se determinó luego de realizar una cromatografía de fase reversa (CFR) para eliminar cualquier sustancia interferente. En la Figura 3.4 se muestra el perfil de elución de la proteína en la CFR. Se puede observar un pico homogéneo que eluye a una concentración de 60 \% de acetonitrilo. El análisis se realizó sobre la fracción central del pico obteniéndose la siguiente secuencia: S-T-C-T-F-T-D-A-A-T-A-S-E-S-K. 


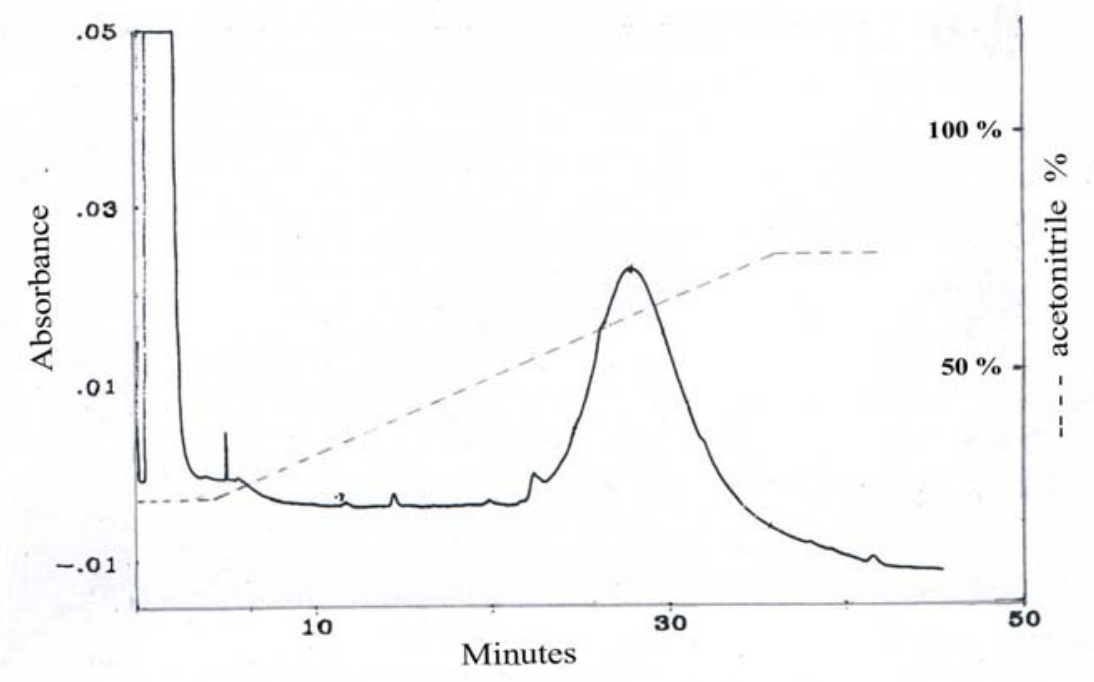

Figura 3.4 Cromatografía de fase reversa de la PGasa ácida (PGI) de A. kawachii.

Columna: Aquapore, C-4, 30 x $2.1 \mathrm{~mm}$, Brownlee, Perkin Elmer, Inc. Elución: gradiente de acetonitrilo (0-80\%) en TFA al 0.08\%. Volumen de fracción: $200 \mu \mathrm{l}$.

\subsubsection{Propiedades de la enzima}

\subsubsection{Efecto de $\mathrm{pH}$ sobre la actividad enzimática}

El perfil pH/actividad de PGI dependió del sustrato (Figura 3.5A). El pH óptimo sobre protopectina de limón y pectina cítrica fue de 2.0 y 2.5, respectivamente. El pH óptimo para la hidrólisis de APG se desplazó hacia la región menos ácida ( $\mathrm{pH}$ 4.5) pero la actividad se mantuvo a pH 2.0 (10 \%). Los valores de actividad con APG a pH $\leq 2.5$ deben interpretarse con precaución debido a la baja solubilidad del sustrato en ese rango de pH. La actividad relativa (al pH óptimo de cada sustrato) sobre APG, protopectina y pectina fue de 1.0, 0.5 y 0.15 , respectivamente. La actividad de una enzima suele ser afectada por la naturaleza del buffer y el tipo de cationes presentes en la reacción. En el caso de PGI, el buffer (BCP y AcOH) y el catión ( $\mathrm{Na}^{+}$o $\mathrm{K}^{+}$) no tuvo efecto en la actividad sobre APG y pectina cuando esta se evaluó al pH óptimo de cada sustrato. La propiedad más resaltable de PGI fue su capacidad de actuar a $\mathrm{pH}<3.0$ y de ser inactiva a $\mathrm{pH}$ 5.0, condiciones opuestas a las que exhiben la mayoría de las PGasas fúngicas. Esto se observa claramente en el perfil pH/actividad que exhibe la PGasa de A. niger sobre protopectina y APG (Figura 3.4B).

Una observación importante del efecto del pH en la actividad enzimática, es que los perfiles pH/actividad de PGI sobre APG y protopectina son muy parecidos a los observados 
con el permeado obtenido luego de filtrar CM por el FFV (Capítulo 2, Figura 2.5). Por lo tanto se concluyó que la actividad PGasa/PPasa ácida del permeado es mayoritariamente debida a PGI
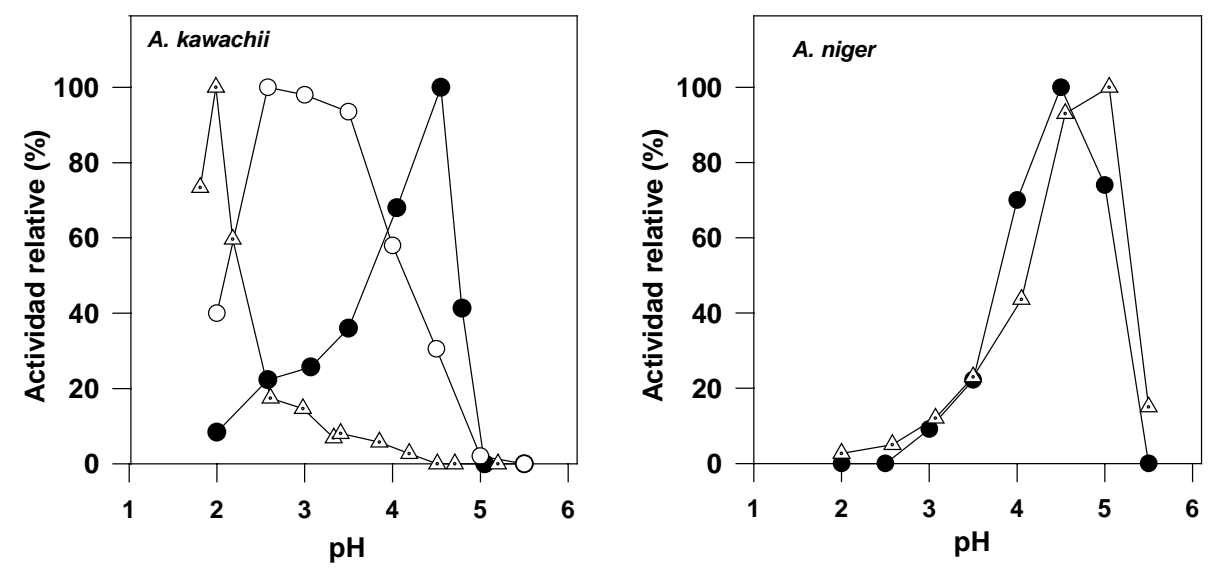

Figura 3.5. Efecto del pH en la actividad de PGI.

La actividad sobre APG, pectina cítrica (GM 53) y protopectina se determinó en BCP según se describe en la sección 3. Los azúcares reductores se determinaron por el método del DNS. La concentración de proteína en la mezcla de reacción fue de 0.04-0.20 $\mu \mathrm{g} / \mathrm{ml}$. A: PGI A. kawachii,

B: PGasa de A. niger. APG (-๑-), Pectina (-○-), y protopectina (- $\triangle$-).

\subsubsection{Estabilidad térmica}

Los experimentos realizados para determinar la estabilidad térmica de PGI mostraron resultados inesperados. A $50{ }^{\circ} \mathrm{C}$ la máxima estabilidad en BCP se encontró a pH mayor de 4.0, mientras que a pH 2.0 la enzima se inactivó rápidamente (Figura 3.6A). Estos resultados son contradictorios con la estabilidad de la actividad PPasa observada en el dializado del medio glucosa (Capítulo 2). Cuando PGI se incubó en presencia de albúmina, la enzima permaneció estable a pH 2.0. La mínima cantidad de albúmina requerida para estabilizar PGI fue $~ 100$ ppm (Figura 3.6B). En base a estos datos se infirió que la estabilidad de la actividad PPasa en el dializado es debida, entre otras causas a la presencia de proteínas (concentración en el dializado $\sim 300$ ppm). Para determinar si la estabilidad a pH 2.0 en presencia de albúmina es una propiedad intrínseca de PGI, se determinó la estabilidad de la PGasa de A. niger en similares condiciones. Como puede observarse en la misma Figura 3.6, la enzima de A. niger se inactivó rápidamente en presencia de albúmina, siendo incluso más pronunciada la inactivación que la observada con PGI sin albúmina, lo cual indica que PGI posee una 
estabilidad característica a pH ácido. Además de proteínas, otros compuestos como sacarosa y alginato tuvieron un efecto protector sobre PGI. En presencia de $500 \mathrm{ppm}$ de estos compuestos la actividad residual después de 30 minutos de incubación a $50{ }^{\circ} \mathrm{C}$ y pH 2.0 fue del $50 \%$. La pectina también mostró un efecto estabilizante ya que la hidrólisis de este sustrato a pH 2.0 y $50{ }^{\circ} \mathrm{C}$ no fue afectada por presencia de albúmina (datos no mostrados).
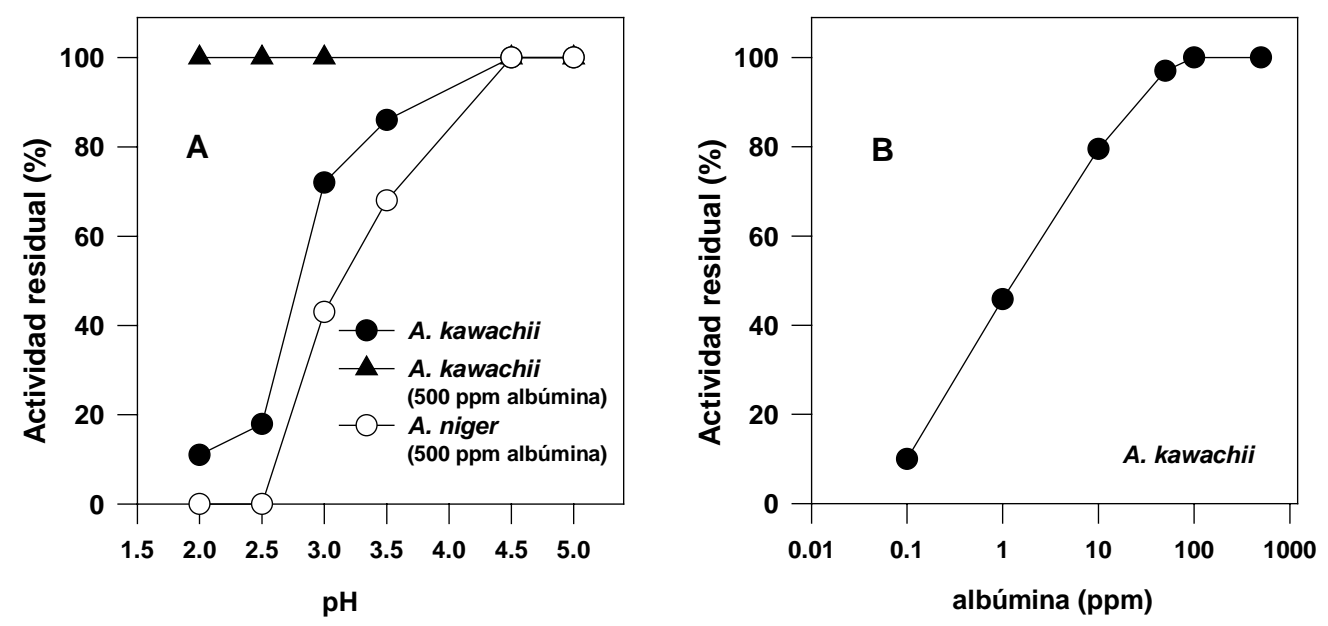

Figura 3.6. Efecto del pH y la presencia de albúmina en la estabilidad térmica de PGasas

A: Actividad residual medida luego de $30 \mathrm{~min}$ de incubación a $50{ }^{\circ} \mathrm{C}$. Condiciones de incubación: BCP, concentración de proteína 0.6-1.0 $\mu \mathrm{g} / \mathrm{ml}$; B: BCP, pH 2.0. Actividad residual medida con 0.5 \% APG en BCP, pH 4.5 .

\subsubsection{Especificidad de sustrato y acción endo/exo}

La enzima purificada no mostró actividad (2 horas de incubación en BCP, pH 4.5 a $37{ }^{\circ} \mathrm{C}$ ) sobre los siguientes sustratos: arabinogalactano, carboximetilcelulosa, xilano y laminarina. Para la caracterización de la acción enzimática sobre sustratos de diferente grado de metoxilación, se determinó el curso de la hidrólisis de APG y pectina cítrica midiendo el incremento del poder reductor en la mezcla de reacción (como ácido galacturónico). La estimación del procentaje de hidrólisis varió según el método empleado para la determinación de azúcares reductores. Los valores con DNS fueron mayores que los calculados con Somogyi-Nelson (S-N) debido a que el reactivo DNS da valores mas altos de azúcares reductores que S-N. La mayor diferencia ocurre al principio de la hidrólisis y luego a medida que avanza la reacción la diferencia tiende a un mínimo. La discrepancia en los valores de reductores puede ser atribuida a que la respuesta (en base molar) de los productos de 
hidrólisis, en particular los oligómeros, comparada con la del ácido galacturónico empleado como patrón, es diferente en ambos métodos (Figura 3.7A). Resultados similares se han observado en la determinación del poder reductor de sustancias pécticas y en la estimación del grado de hidrólisis producido por la acción de glucanasas sobre sustratos poliméricos [Breuil and Saddler, 1985]. Independientemente de las discrepancias, las conclusiones obtenidas en ambos casos son las mismas, esto es, el APG es hidrolizado mas rápidamente y en una mayor extensión que el sustrato metoxilado pectina. Cuando la pectina fue parcialmente desesterificada con PME, la velocidad de hidrólisis y la degradación del sustrato se incrementó. Por otra parte, PGI prácticamente no hidrolizó pectinas altamente esterificadas (GM > 90 \%). Estos resultados demuestran que PGI es una clásica poligalacturonasa, es decir hidroliza las regiones no esterificadas o pobremente esterificadas de la pectina.

Para determinar si el mecanismo de acción de PGI es endo o exo, se determinó la relación entre la disminución de viscosidad de los sustratos y el \% de enlaces glicosídicos hidrolizados (en este caso estimado por el método de S-N). Los resultados se muestran en la Figura 3.7B. Con fines comparativos, se utilizó también la endo-PGasa de A. niger. La acción enzimática fue la esperada para una hidrólisis de tipo endo, es decir una marcada disminución (50 \%) de viscosidad (debida a la disminución del peso molecular del polímero) para una hidrólisis reducida del sustrato, en este caso $3 \%$ (pectina) y $8 \%$ (APG). Similares resultados (con APG) se obtuvieron con la PGasa de A. niger (no mostrados).

La actividad viscosimétrica es útil para caracterizar el modo de acción enzimática sobre sustratos poliméricos pero no da información acerca de la distribución de los productos de hidrólisis. Para obtener mayor información sobre la hidrólisis de APG y pectina con PGI, se realizó un análisis cromatográfico de los productos de reacción en función del grado de hidrólisis, los cuales proveen una valiosa información del patrón de degradación del sustrato. A tal fin, los productos de hidrólisis del APG y pectina se analizaron mediante TLC y CTM. A efectos comparativos se incluyó en el análisis por TLC la degradación de APG por la PGasa de A. niger. En la Figura 3.8A se muestra los resultados del TLC para ambas enzimas. Se observa claramente que el polímero es inicialmente degradado a oligómeros (confirmando la acción endo), los cuales se acumulan transitoriamente para ser luego hidrolizados a mono, di- y tri-galacturonatos, productos estos que predominan a altos grados de hidrólisis (45-50 $\%)$, junto con tetra- y penta-galacturonatos (estos últimos son solo tentativos ya que no se dispuso de los correspondientes patrones). En el caso de PGI, la presencia de mono, di- y trigalacturonatos se observa en forma significativa desde las primeras etapas de la hidrólisis, no así para la PGasa de A. niger. Para el análisis por CTM se emplearon muestras de A. kawachii 
de APG y pectina con $45 \%$ (Figura 3.8B) y 7 \% de hidrólisis respectivamente, que corresponden a incubaciones de 24 h. Para A. niger se empleó una muestra de APG con 30-35 \% de hidrólisis que corresponde a una incubación de 12 h. En la Figura 3.11B se muestra el patrón de elución de los productos de degradación de APG. Tal como cabía esperar de los resultados del TLC, se observa un pico principal que corresponde a compuestos de bajo peso molecular, es decir que eluyen mayoritariamente con o cerca del volumen de columna $(\mathrm{Kv}=1)$, y además un muy pequeño pico (indicado con una flecha) de alto peso molecular que eluye con el volumen de exclusión. Este material no degradado podría corresponder a una pequeña fracción de RG presente en el sustrato que no es hidrolizado por PGasas. Con respecto a la hidrólisis de pectina, se observa una distribución amplia de productos con predominio de los de alto PM, lo cual demuestra que este sustrato no puede ser degradado (o lo es muy lentamente) por las restricciones que impone la presencia de grupos metoxilos en la molécula.

\subsubsection{Parámetros cinéticos sobre APG}

Los parámetros cinéticos de PGI sobre APG fueron determinados en BCP, pH 4.5 a $37^{\circ} \mathrm{C}$ (ensayo de reductores Somogyi-Nelson). Los parámetros cinéticos calculados fueron: $\mathrm{Km}=$ $0.192 \pm 0.028 \mathrm{mg} / \mathrm{ml}$ y una $\mathrm{Vmax}=0.0747 \pm 0.0029 \mu \mathrm{mol} /(\min \mathrm{x} \mathrm{ml})$. La actividad específica fue estimada en $1500 \mu \mathrm{mol} /\left(\min \mathrm{x}\right.$ mg de proteína) o $25 \mu \mathrm{kat} \mathrm{mg}^{-1}$. El bajo valor de Km nos indica que APG es un buen sustrato para PGI.

\subsection{Discusión}

Los resultados del proceso de purificación y las propiedades exhibidas por PGI demuestran que esta PGasa es mayoritariamente responsable de la actividad pectolítica ácida (pH 2.0-2.5) presente en el medio glucosa. El proceso de purificación involucró cuatro etapas: concentración a presión reducida, precipitación con acetona, cromatografía de intercambio aniónico y permeación por gel. En la primera etapa no se utilizó pepstatina para inhibir la proteasa ácida, encontrándose sin embargo muy buena estabilidad de la enzima a pH 3.0 y $40^{\circ} \mathrm{C}$ dentro de los tiempos característicos de la operación de concentración (6-12h). Bailey and Ojamo [1990] evaluaron el proceso de concentración a presión reducida de una PGasa de A. niger cultivado en medio líquido y encontraron una significativa pérdida de actividad enzimática. En ese trabajo no se reportó el pH utilizado durante la operación, el cual de acuerdo a nuestro estudio es un factor crítico para mantener la actividad catalítica. 

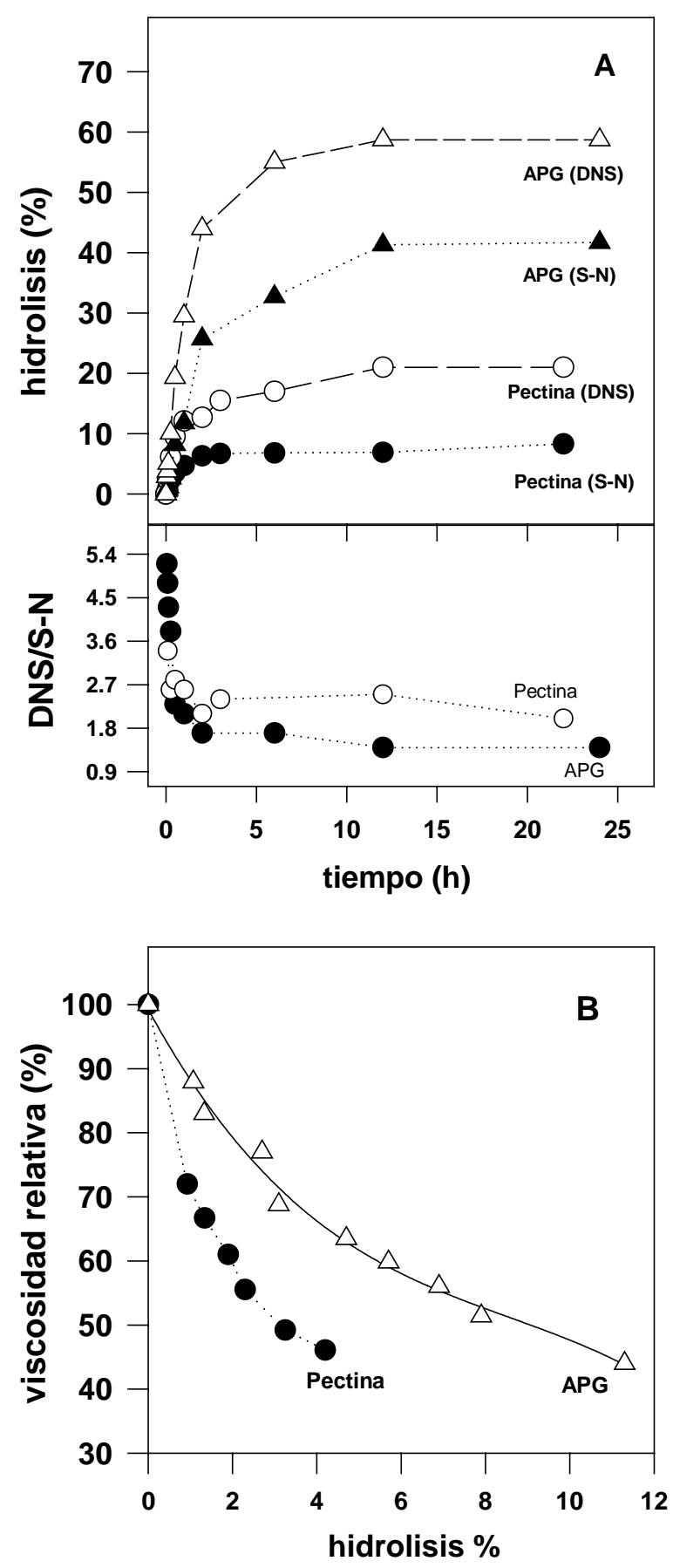

Figura 3.7. Hidrólisis de APG y pectina cítrica por PGasas

A: Hidrólisis de APG y pectina en función del tiempo de reacción determinada por medidas de azúcares reductores; S-N Método Somogyi-Nelson. APG: buffer AcONa, pH 4.5, concentración de proteína (PGI) $0.08 \mu \mathrm{g} / \mathrm{ml}$; Pectina (GM 53), BCP pH 2.5, concentración de proteína (PGI) $0.24 \mu \mathrm{g} / \mathrm{ml}$.

B: Cambios de viscosidad en función del grado de hidrólisis para APG y Pectina. Concentración de proteína (PGI) en la mezcla de reacción 0.04-0.11 $\mu \mathrm{g} / \mathrm{ml}$. Porcentaje de hidrólisis determinado mediante el análisis de azúcares reductores con Somogyi-Nelson. 
Por otro lado, Lee et al. [1997] evaluaron el efecto del solvente orgánico sobre la recuperación de protopectinasa de Bacillus subtilis IFO 12113. En dicho trabajo se encontró que el metanol fue mejor solvente orgánico para recuperar la actividad protopectinasa que el etanol o la acetona. En nuestro caso no empleamos metanol por su toxicidad obteniendo muy buenos resultados con acetona (se requirió menor volumen que etanol). El procedimiento finalmente adoptado para obtener un concentrado de enzima previo a la cromatografía aniónica dió una recuperación de actividad entre el 70 y 90 \% (en varios lotes) y una solución de PGasa 60-70 veces mas concentrada que la del cultivo. Este concentrado tiene a PGI como la principal actividad pectinasa ya que las PGasas moderadamente ácidas fueron mayoritariamente removidas durante la filtración por el FFV y en el medio glucosa/triptona no se expresan (o lo hacen en un nivel muy bajo) otras pectinasas (Capítulo 2). Esto fue confirmado pues no se detectó actividad liasa, ni PME en el concentrado.

La CIAN resultó altamente selectiva para PGI, debido en parte a que esta proteína se adsorbió fuertemente a la matriz de Sepharose Q mientras que la mayoría de las proteínas contaminantes o bien no se adsorbieron ( $\mathrm{pI}>5.0$ ) o eluyeron con fuerza iónica moderada. La CTM empleada al final permitió eliminar impurezas de bajo peso molecular. El preparado final obtenido fue homogéneo según el análisis por SDS-PAGE. El mayor peso molecular estimado por electroforesis en comparación con el calculado por tamiz molecular en Sephacryl S-100, sugiere algún tipo de interacción entre PGI y el relleno de la columna que retarda su elución. En este sentido existen algunos reportes que mencionan la posible adsorción de glicoproteínas a Sephacryl [Tong et al., 2001].

La presencia de múltiples formas de la misma enzima ha sido frecuentemente reportada para las PGasas fúngicas. Esta multiplicidad deriva de diferencias en la glicosilación de la proteína o de variaciones genéticas reales, por ejemplo, cambios en ciertos aminoácidos de la cadena polipeptídica. Las isoformas pueden presentar las mismas propiedades cinéticas, como pH óptimo y patrón de degradación de APG, masa molecular e incluso secuencia N-terminal [Stratilová et al., 1993; Caprari et al., 1993; Shanley et al., 1993]. Sin embargo, suelen diferir en el pI y por lo tanto la microheterogeneidad se hace evidente en el IEF cuando se realiza la tinción del gel para proteína y actividad. En el caso de PGI dicha microheterogeneidad fue prácticamente inexistente ya que el IEF mostró la presencia casi exclusiva de una banda de proteína con actividad PGasa a pH 2.5 que pero inactiva a pH 5.0, lo cual confirma a su vez la presencia de la PGasa ácida en la muestra. La Concavalina A ha sido utilizada para evaluar las características glicoproteicas de diversas PGasas tanto de origen vegetal [Stratilova et al., 1996] como de origen fúngico [Raab, 1992; Stratilova et al., 1998]. 
A
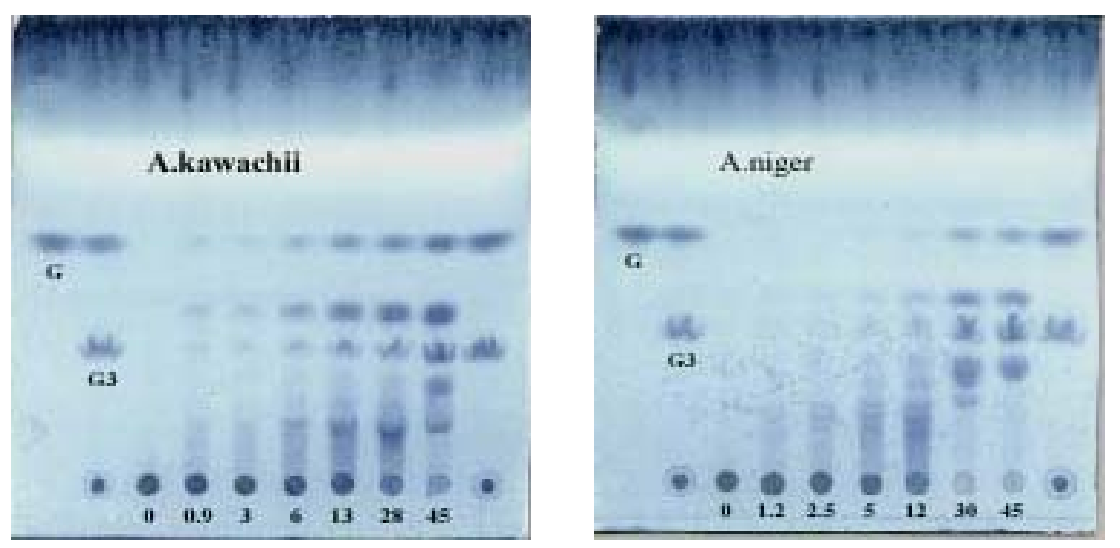

B
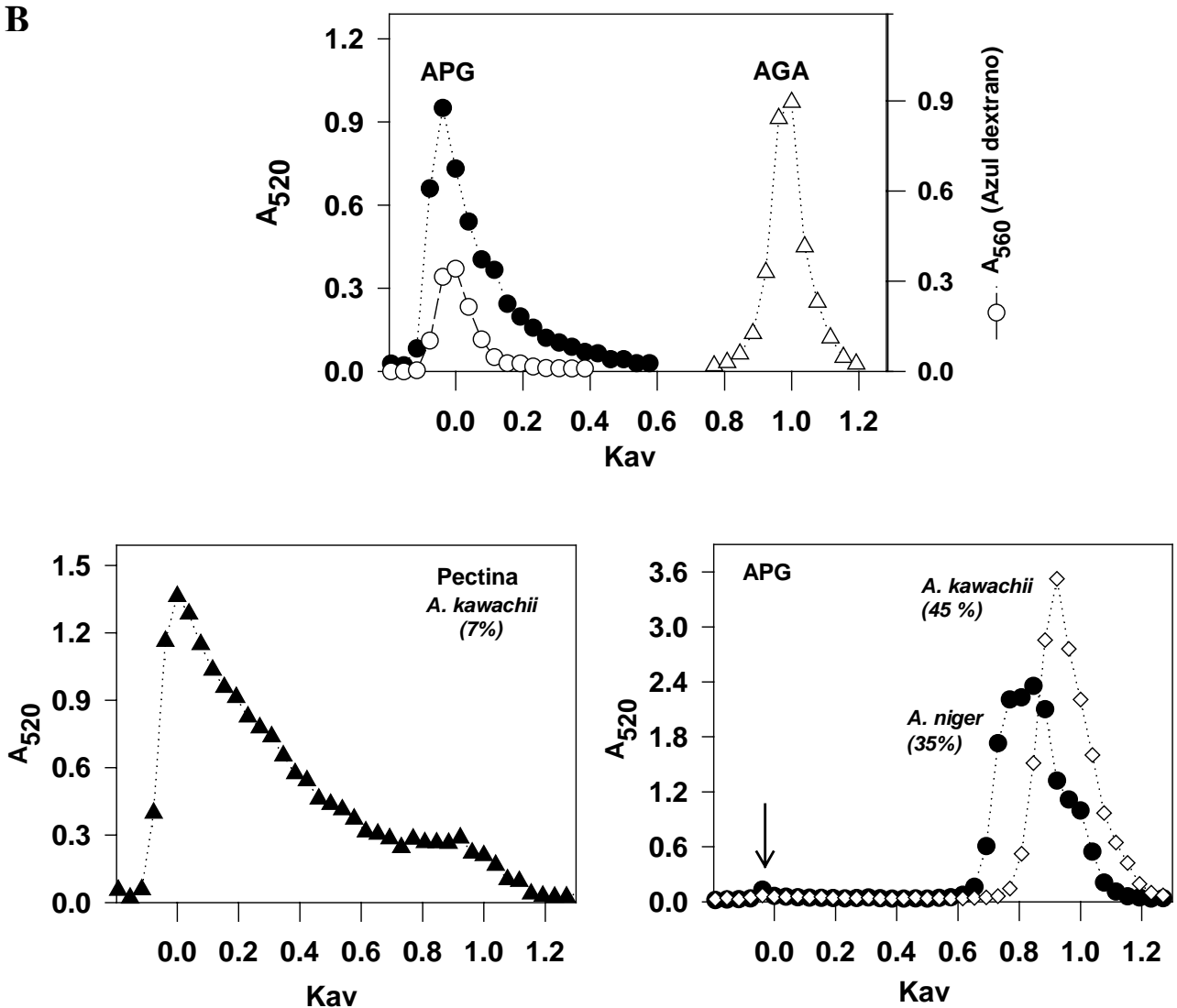

Figura 3.8. A: TLC de los productos de hidrólisis de APG. Los números debajo del punto de siembra indican el porcentaje de hidrólisis de la muestra según el análisis de reductores con Somogyi-Nelson method. $G$ y $G_{3}$ patrones de ácido galacturonico y trigalacturónico respectivamente. Todos los ensayos de hidrólisis fueron realizados a $37^{\circ} \mathrm{C}$. B: Perfil de elusión de compuestos urónicos de alto (oligo sacáridos y polisacáridos) y bajo peso molecular. 
PGI mostró la propiedad de adsorberse a ConA-Sepharose lo cual sugiere que es una glicoproteína. Los resultados del tratamiento con PNGasa F realizado para determinar la presencia de uniones $\mathrm{N}$-glicosídicas no fueron concluyentes. Este resultado no es fácil de explicar ya que en general las PGasas fúngicas glicosiladas muestran una respuesta positiva a la incubación con PNGasa F. Si la falta de respuesta de PGI obedece a una propiedad particular de la enzima o a las condiciones de incubación empleadas, es algo que resta por elucidar.

La propiedad más representativa de PGI cuando se la compara con otras PGasas fúngicas, es su capacidad para hidrolizar sustratos solubles e insolubles en el rango de $\mathrm{pH}$ 2.0-3.0 y de ser inactiva a $\mathrm{pH}$ 5.0. Para sustratos como protopectina y pectina el $\mathrm{pH}$ óptimo de actividad fueron en el rango mencionado, en cambio con APG el valor óptimo se corre a un valor menos ácido ( $\mathrm{pH}$ 4.5) aunque la actividad sigue siendo significativa a $\mathrm{pH}$ 2.0. La baja actividad relativa de PGI frente a APG en el rango de $\mathrm{pH}$ 2.0-3.0 no puede interpretarse simplemente por una disminución de la solubilidad del sustrato, ya que la precipitación del polímero se manifiesta en forma significativa recién a $\mathrm{pH} \leq 2.5$. Un comportamiento similar se observó para la endo-PGasa de Candida macedoniensis [Call et al, 1985]. Esta enzima presentó actividad máxima sobre APG a pH 4.5, mientras que el pH óptimo de maceración sobre material insoluble (discos de zanahoria) fue 2.5. Estas diferencias fueron explicadas por un efecto del pH sobre la conformación de la enzima, que determina a su vez un cambio de afinidad por los sustratos. Las diferencias en el pH óptimo frente a APG y sustratos insolubles parece ser característico de ciertas PGasas y no se puede generalizar, ya que en el caso de la PGasa de A. niger, los perfiles de pH/actividad sobre ambos sustratos fueron similares.

La propiedad de una enzima de ser activa en una determinada condición está íntimamente relacionada con su estabilidad. En general, PGI no presentó problemas de estabilidad frente a refrigeración, congelación o liofilización, característica muy importante para considerar desde el punto de vista industrial. Este comportamiento diferencia PGI de muchas PGasas, incluyendo a las moderadamente ácidas de A. kawachii (Capítulo 5), que son particularmente sensibles a este tipo de procesos [Anjana-Devi and Rao, 1996]. A pH muy ácido (2.0-3.0) la estabilidad de PGI parece depender de la presencia de sustancias estabilizantes como proteínas, polisacáridos o azúcares simples. La estabilización de PGI es inherente a su estructura, ya que la PGasa de A. niger fue rápidamente inactivada a pH muy ácido, aún en presencia de albúmina. La estabilización de proteínas por este tipo de compuestos es ampliamente conocida. El mecanismo de protección probablemente se relacione con interacciones del tipo hidrofóbico (efecto albúmina) que estabilizan la proteína nativa, alguna 
estructura intermedia o evitan la disociación (cuando es multimérica) o por modificaciones en el microentorno acuoso (formación de puentes de hidrógeno, exclusión de solutos, etc) para el caso de azúcares y polioles [Anjana-Devi and Rao, 1998]. La estabilización de las enzimas por el sustrato es también un fenómeno ampliamente conocido. Bajo condiciones reactivas, es de esperar que tanto el sustrato como los productos de reacción jueguen un papel importante en la estabilización del catalizador. Al respecto se han propuestos modelos de reacciones enzimáticas que contemplan esta situación [Illanes, 1994].

Las propiedades cinéticas de PGI corresponden a una endo-PGasa. Se han propuesto diversos mecanismos para describir la acción endo de polisacaridasas, los cuales fueron primeramente aplicados a describir la acción de amilasas y luego extendidos a las pectinasas [Robyt et al., 1967; Pascualli et al., 1991; Benen et al., 1999]. En el mecanismo de ataque múltiple, la enzima puede catalizar la hidrólisis de varios enlaces (procesividad) antes de disociarse y formar un nuevo complejo activo con otra cadena de polisacárido. Este mecanismo resulta en la liberación de oligogalacturonatos desde el inicio de la reacción enzimática simultáneamente a la generación de oligómeros de alto peso molecular representativos del ataque aleatorio (random) de la enzima. Este mecanismo sería semejante al modo exo/endo de hidrólisis de APG descripto por Cook et al. [1999]. El análisis preliminar de degradación de APG mediante TLC muestra la presencia de mono-, di-, y trigalacturonatos a tiempos muy cortos de reacción, lo cual sugiere que la enzima degrada el sustrato con un cierto grado de múltiple ataque. Estos productos se acumulan en el transcurso de la reacción lo cual es consistente con el hecho de que las endo-PGasas no hidrolizan digalacturonato y atacan muy lentamente al trigalacturonato [Benen et al.,1996]. Estos resultados muestran que el mecanismo de acción de PGI es en términos generales comparable al descripto en otras endo-PGasas. Sin embargo, aún dentro de este grupo existen variaciones significativas en los productos de hidrólisis de APG. En este sentido, se requiere un análisis pormenorizado de los oligogalacturonatos formados por la hidrólisis de oligómeros de cadena definida para obtener una mayor información del modo de acción de PGI [Benen et al., 1999].

Tal como se mencionó en el Capítulo 1, existen algunos reportes de pectinasas de $A$. kawachii. Los primeros estudios describen la actividad PGasa como licuefaccionante y sacarificante (similar alo descripto para amilasas), en función de su capacidad para macerar discos de papa y con pH óptimo sobre APG de 4.5 y 5.5 respectivamente [Hayashi, 1958; Ozawa et al, 1959]. En un trabajo mas reciente se reportó la purificación de tres PGasas de la cepa IFO 4308 (la empleada en este trabajo) a partir de cultivos crecidos en un medio con 
harina de soja y peptona [Kojima et al, 1999]. La producción de estas PGasas dependió del pH del medio. Las PGasas A1 y A2 (PGase-A1 and PGase-A2) fueron producidas mayoritariamente bajo condiciones de cultivo ácidas (pH inicial 2.0) y la PGasa B (PGaseB) predominó en cultivos moderadamente ácidos ( $\mathrm{pH}$ inicial 5.0). Ninguna de estas enzimas presenta propiedades comparables a PGI. En el caso de la PGasa A1, el perfil de pH/actividad sobre APG es muy parecido al de PGI, pero el pH óptimo para este sustrato fue de 4.0. Otras discrepancias importantes se observan en la secuencia N-terminal (Figura 3.9). Las secuencias de la PGasa A1 y A2 no muestran ninguna homología con la secuencia de PGI, sin embargo la PGasa que se expresa mayoritariamente en los cultivos de $\mathrm{pH}$ 5.0, si presenta algún grado de homología. Una explicación de estas diferencias no es inmediata y se requieren otros estudios para clarificar la situación. Por otra parte PGI tiene propiedades semejantes a la PPasa-AS (en realidad una endo-PGasa) de A. awamori, que fue purificada de extractos de cultivos sólidos en afrecho de trigo [Nagai et al., 2000]. El gen que codifica la PPasa-AS fue aislado y secuenciado [Nagai et al., 2000]. Ambas enzimas tiene similares pI, peso molecular y pH óptimo sobre protopectina (el perfil pH/actividad sobre APG de la PPasa-AS no fue reportado). Mas aún ambas proteínas muestran una secuencia N-terminal casi idéntica y están glicosiladas. En la Figura 3.9 se muestra la secuencia de aminoácidos de la PPasa-AS deducida de la secuencia nucleotídica del gen, donde se remarca los aminoácidos potencialmente involucrados en la N-glicosidación. (secuencia Asn-X-Ser/Thr, donde X es cualquier otro aminoácido diferente de la prolina). Teniendo en cuenta que A. kawachii y A. awamori son especies fúngicas estrechamente relacionadas, es probable que ambas enzimas sean codificadas por un mismo o muy semejante gen.

Tabla 3.3. Secuencia N-terminal de algunas PGasas de Aspergillus

\begin{tabular}{|c|c|c|c|}
\hline Origen & Nombre & Secuencia N-terminal & Referencias \\
\hline \multirow{3}{*}{ A. awamori } & PPasa-AS & 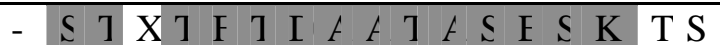 & Nagai et al., 2000a \\
\hline & PGasa-X2 & $-\mathrm{DSC}] \mathrm{F} T \mathrm{~T} f t \mathrm{~A} f \mathrm{KAGK}$ A K & Nagai et al., 2000a \\
\hline & PGasa-XR-R & $-\mathrm{DSC} T \mathrm{~F} T \mathrm{~T} f f \mathrm{~A} f \mathrm{~K}$ & Nagai et al., 2000b \\
\hline \multirow[t]{2}{*}{ A. flavus } & PecA & $-\mathrm{DSC} T \mathrm{~F} T \mathrm{~S} f f \mathrm{D} f \mathrm{KS} \mathrm{GK} \mathrm{TS}$ & White et al., 1995 \\
\hline & PecB & $\mathrm{G} \leqslant \mathrm{S}(\mathrm{I} \mathrm{F}] \mathrm{S} f f \mathrm{Q} f \leqslant \mathrm{~A} \leqslant \mathrm{~A} \mathrm{KS}$ & White et al., 1995 \\
\hline \multirow[t]{3}{*}{ A. kawachii } & PGasa-A1 & L N C P GXL S - & Kojima et al., 1999 \\
\hline & PGasa-A2 & K P K T Y Y H X V Y - & Kojima et al., 1999 \\
\hline & PGasa-B & A D $]$ X 7 F 7 X $\Leftrightarrow \Leftrightarrow$ & Kojima et al., 1999 \\
\hline A. kawachii & PG I & $-\leqslant T(I F T I f f I f \leqslant \mathrm{E} \leqslant \mathrm{K}$ & En este trabajo \\
\hline \multirow[t]{4}{*}{ A. niger } & PG I & $-\leq I C J \mathrm{~F} T \mathrm{~S} / \mathrm{S} E f \leqslant \mathrm{E} \leqslant \mathrm{I} \mathrm{SS}$ & Bussink et al., 1991 \\
\hline & PG II & $-\mathrm{DS} C \mathrm{IF} \mathrm{T} \mathrm{T} f f \mathrm{~A} f \mathrm{KAGK}$ A K & Keon et al., 1990 \\
\hline & PG C & A T T C I F S G E G $f \subseteq K A S$ KS & Bussink et al., 1992 \\
\hline & PG E & S P V A D F L V T P - F P K L E L L & Parenicová et al., 1988 \\
\hline A. oryzae & PG & $-\mathrm{DSC}] \mathrm{F} T \mathrm{~S} f t \mathrm{D} f \mathrm{KS} \mathrm{GK} \mathrm{TS}$ & Kitamoto et al., 1993 \\
\hline
\end{tabular}


Translación de la secuencia de bases de la PPasa AS (Nagai et al., 2000a)

"MPSAKPLFCLATLAGAALAAPAPSRATDFNKRSTCTFTDAATASESKTSCSDIVLKDI TVPAGETLNLKDLNDGTTVTFEGTTTWEYEEWDGPLLRISGKDITVTQSSDAVLNGN GAKWWDGEGTNGGKTKPKFFYAHDLDDSKISGLYIKNTPVQAISVDNLVIEDVTIDN SDGDSEGGHNTDGFDISESTYITITGATVKNQGDCVAINSGENIYFSGGTCSGGHGLSI GSVGGRDDNTVKNVTFIDSTVSDSENGVRIKTVYDATGTVEDITYSNIQLSGISDYGIV IEQDYENGDPTGTPSNGVTISDVTLEDITGSVDSDAVEIYILCGDGSCTDWTMSGIDIT GGETSSDCENVPSGASCSQ"

Secuencia homóloga a PGI

Sitio potencial de glicosidación 


\subsection{Referencias bibliográficas}

Bailey, M.J. and Ojamo, H. (1990). Downstream processing of extracellular enzymes of Aspergillus niger. En: Separation for Biotechnology, Vol 2. D.L. Pyle (ed.). Elsevier Science : London pp:529-538.

Behere, A.; Satyanarayan, V. and Padwal-Desai, S.R. (1993). Separation and limited characterization of three polygalacturonases of Aspergillus niger. Enzyme Microbiology Technology, 15:158-161.

Benen, J.A.E.; Kester, H.C.M.; Pareniková, L.; Visser, J. (1996). Kinetics and mode action of Aspergillus niger polygalacturonases. In: Pectins and Pectinases. J. Visser and A.G.J. Voragen (Eds). Elsevier Science B.V.: Amsterdam, pp:221-230.

Benen, J.A.E.; Kester, H.C.M. and Visser, J. (1999). Kinetic characterization of Aspergillus niger N400 endopolygalacturonases I, II and C. European Journal Biochemistry, 159:577585.

Blumenkrantz, N. and Asboe-Hansen, G. A. (1973). Method for quantitative determination of uronic acids. Analytical Biochemistry, 54:484-489.

Breuil, C. and Saddler, J. N. (1985). A comparison of various cellulase assay procedures for measuring the cellulolytic activity of Trichoderma harzianum E58. Biochem. Soc. Trans., 13:449-50

Bussink, H.J.D.; Brower, K.B.; de Graaff, L.H.; Kester, H.C.M. and Visser, J. (1991). Identification and characterization of a second polygalacturonase gene of Aspergillus niger. Current Genetic, 20:301-307.

Bussink, H.J.D.; Buxton, F.P.; Fraaye, B.A.; Graaff, L.H.; Visser J. (1992). The polygalacturonases of Aspergillus niger are encoded by a family of diverged genes. Eur $J$ Biochem. 208: 83-90.

Call, H.P.; Walter, J. and Emeis, C.C. (1985). Maceration activity of an endopolygalacturoanse from Candida macedoniensis. Journal of Food Biochemistry, 9:325-348.

Contreras-Esquivel J.C.; Hours, R.A.; Voget, C.E. and Mignone, C.F. (1999). Aspergillus kawachii produces an acidic pectin releasing enzyme activity. Journal Bioscience Bioengineering, 88:48-52..

Cook, B.J.; Clay, R.P.; Bergmann, CW, Albersheim, P. and Darvill, A.G. (1999). Fungal polygalacturonases exhibit different substrate degradation patterns and differ in their susceptibilities to polygalacturonase-inhibiting proteins. Mol. Plant-Microbe Interact. 12:703-711. 
Devi, N.A. and Rao, A.G.A. (1996). Fractionation, purification, and preliminary characterization of polygalacturonases produced by Aspergillus carbonarius. Enzyme Microbiology Biotechnology, 18:59-65.

Devi, N.A. and Rao, A.G.A. (1998). Effect of additives on kinetic thermal stability of polygalacturonase II from Aspergillus carbonarius: mechanism of stabilization by sucrose. Journal Agricultural and Food Chemistry, 46:3540-3545.

Hara, T.; Fujio, Y. and Ueda, S. (1986). Clarification of apple juice with polygalacturonase of Aspergillus niger and pectinesterase of Asp. oryzae and their protopectin adsorption and degradation behaviour. Nippon Shokunhin Kogyo Gakkaishi, 33:336-341.

Hayashi, T. (1958). The pectic enzyme produced by microorganisms. I. Pectin galacturonase of Aspergillus kawachii. Hakko Kôaku Zzasshi, 36:246-248. Chem. Abs. 52:18565g

Hoondal, G.S.; Tiwari, R.P.; Dahiya, N.; Dahiya, N. and Beg, Q.K. (2002). Microbial alkaline pectinases and their industrial applications: a review. Applied Microbiology Biotechnology, 59409:409-418.

Illanes, A. (1994). Biotecnología de enzimas. OEA, Serie Biología, Monografía No. 35. Ediciones Universitarias de Valparaíso de la Universidad Católica de Valparaíso, Chile. pp:1-256.

Ishii, S. and Yokotsuka, T. (1972). Purification and properties of endo polygalacturonase from Aspergillus japonicus. Agricultural and Biological Chemistry, 36:1885-1893.

Kaji, A. and Okada, T. (1969). Purification and properties of an unusually acid-stable endoplygalacturonase produced by Corticium rolfsii. Arch. Biochem Biophys, 131:203209.

Keon, J.P.R. and Waksman, G. (1990). Common amino acid domain among endopolygalacturonases of ascomycete fungi. Applied Environmental Microbiology, 56:2522-2528.

Kester H.C.M. and Visser, J. (1990). Purification and characterization of polygalacturonases produced by the hyphal fungus Aspergillus niger. Biotechnology and Applied Biochemistry, 12:150-160.

Kitamoto, N.; Kimura, T.; Kito, Y.; Omura, K. and Tsukagoshi, N. (1993). Structural features on polygalacturonase gene cloned from Aspergillus oryzae KBN 616. FEMS Microbiology Letters, 111:37-42.

Kojima, Y.; Sakamoto, T.; Kishida, M.; Sakai, T. and Kawasaki, H. (1999). Acidic conditioninducible polygalacturonase of Aspergillus kawachii. Journal of Molecular Catalysis B: Enzymatic, 6:351-357. 
Labavitch, J.M. and Rae, H.L. (1977). A purified polygalacturonase for cell wall analysis. Journal of Food Biochemistry, 1:301-309.

Lee, S.C.; Yuk, H.G. and Hwang, Y.I. (1997). Recovery yields of protopectinase depending of treatments of organic solvents. Agricultural Chemistry and Biotechnology, 40:107-111.

Leuchtenberger, A.; Krause, M.; Junghans, H.; Mayer, G. and Walzel, J. (1992). Isolation of A. niger mutants with protopectinase activity at very low pH. BioEngineering, 4:36-43.

Lowry O.H.; Rosebrough, N.J.; Farr, A.L. and Randall, R.J. (1951). Protein measurement with the Folin phenol reagent. Journal Biological Chemistry, 193:265-75.

Matsuhashi, S.; Inoue, S.I. and Hatanaka, C. (1992). Simultaneous measurement of the galacturonate and neutral sugar contents of pectic substances by an enzymatic-HPLC method. Bioscience Biotechnology Biochemistry, 56:1053-1057.

Miller, G.L. (1959). Use of dinitrosalicylic acid reagent for determination of sugar. Analytical Chemistry, 31:19.

Nagai, M.; Ozawa, A.; Katsuragi, T. and Sakai, T. (2000a). Purification and chracterization of acid-stable protopctinase produced by Aspergillus awamori in solid-state fermentation. Bioscience, Biotechnology and Biochemistry, 64:1337-1344.

Nagai, M.; Ozawa, A.; Katsuragi, T.; Kawasaki, H. and Sakai, T. (2000b). Cloning and heterologus expression of gene encoding a polygalacturonase from Aspergillus awamori. Bioscience, Biotechnology and Biochemistry, 64:1580-1587.

Ozawa, J.; Okamoto, K.; Hayashi, T. (1959). Pectin polygalacturonase of Saccharomyces fragilis. Nogaku Kenkyu, 47:105-110.

Parenicová, L.; Benen, J.A.E.; Kester, H.C.M. and Visser, J. (1988). pgaE encodes a fourth member of the endopolygalacturonase gene family from Aspergillus niger. European Journal of Biochemistry, 251:72-80.

Pascualli, R.; Geraeds, C.; Voragen, F. and Pilnik, W. (1991). Characterization of polygalacturonase from yeast and fungi. Food Science and Technology, 24:63-70.

Raab, B. (1992). Characterization of endopolygalacturonase (EC 3.2.1.15) from Aspergillus niger as glycoprotein by electrophoretic methods and lecitin affino-blotting. Electrophoresis, 13:807-808.

Rao, N.M.; Kembhavi, A.A. and Pant, A. (1996). Implication of tryptophan and histidine in the active site of endo-polygalacturonase from Aspergillus ustus: elucidation of the reaction mechanism, Biochimica et Biophysica Acta (BBA) - Protein Structure and Molecular Enzymology, 1296: 167-173. 
Robyt, J.J. and French, D. (1967). Multiple attack hypothesis of $\alpha$-amylase action: action of porcine, pancreatic, human salivary, and Aspergillus oryzae $\alpha$-amylases. Archives Biochemistry Biophysic, 122:8-16.

Smith B.J. (1984). SDS polyacrylamide gel electrophoresis of proteins. En: Methods in Molecular Biology. Walker JM, (Ed). Vol 1 Proteins. Clifton, New Jersey: The Humana Press Inc, 1984. pp:41-56.

Somogyi, M. (1952). Note on sugar determination. Journal Biological Chemistry, 195:19-23.

Stratilova, E.; Markovic, O.; Skrovinova, D.; Rexová-Benková, L. and Jornvall, H. (1993). Pectinse Aspergillus sp. polygalacturonase: multiplicity, divergence, and structural patterns linking fungal, baterial, and plant polygalacturoonases. Journal Protein Chemistry, 12:1522.

Stratilova, E.; Mislovicova, D. and Dzurova, M. (1996). Purification of exopolygalacturonase by affinity chromatography on concavalin A-bead cellulose. Biotechnology Techniques, 10:363-366.

Stratilova, E.; Mislovicova, D.; Kacurakova, M.; Machova, E.; Kolarova, N.; Markovic, O. and Jornvall, H. (1998). The glycoprotein character of multiple forms of Aspergillus polygalacturonase. Journal Protein Chemistry, 17:173-179.

Thibault, J.-F. and Mercier, C. (1978a). Aspergillus niger endopolygalacturonase: 1. Studies on purification by agarose gel chromatography. J. Sci. Phase Biochem., 2:295-304.

Tong, D.; Hetenyi, Cs.; Bikadi, Zs.; Gao, J.-P.; Hjerten, S. (2001). Some studies of the chromatographic properties of gels ("artificial antibodies/receptors") for selective adsorption of proteins. Chromatographia, 54:7-14.

White, M.P.; Shieh, M.T.; Cleveland, T.E.; Cary, J.M.; Dean, R.A. (1995). Isolation and characterization of polygalacturonase genes (pecA and pecB) from Aspergillus flavus. Applied Environmental Microbiology, 61:3316-3322. 


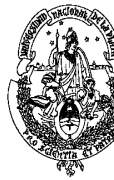

UNLP

Argentina

\section{$\mathrm{C}^{\mathrm{APITULO}} 4$}

Tesis Doctoral

\title{
4. Extracción enzimática de pectina y maceración de tejidos vegetales con poligalacturonasa ácida de Aspergillus kawachii
}

\author{
Resumen
}

Se evaluó la propiedad de la endo-poligalacturonasa ácida (PGI) de A. kawachii de extraer pectina de protopectina y pomaza de limón (PL), y de macerar tejidos vegetales. Las protopectinas se prepararon por diversas metodologías y se caracterizaron física $\mathrm{y}$ químicamente. Los análisis químicos mostraron únicamente diferencias en el grado de esterificación (GM), atribuíble al método de preparación, mientras que el análisis de las isotermas de adsorción de agua sugiere que la porosidad de las diferentes protopectinas es similar. No obstante, la capacidad de hinchamiento mostró una aparente correlación positiva con GM. La solubilización de pectina con PGI a pH 2.0 varió para las diferentes protopectinas siendo menor la solubilización con los sustratos de menor GM, contrariamente a lo esperado para una poligalacturonasa. Este comportamiento más allá de ser un fenómeno de superficie o porosidad, se trataría de un efecto relacionado con la baja solubilidad de las pectinas dentro de la matriz a pH 2.0. lo que impide la liberación de los productos de hidrólisis y/o bien restringe la hidrolisis enzimática. Los sustratos de esterificación intermedia parecen ser los más ventajosos para extraer pectina a $\mathrm{pH} 2.0$ ya que presentan un balance óptimo entre la cantidad de material solubilizado y la contribución de la enzima al proceso de extracción. PGI solubilizó pectina de pomaza de limón (GM 58) con características semejantes a la obtenida mediante extracción química. Los perfiles de las cromatografías de permeación por gel e intercambio iónico y el análisis por FTIR indican que los extractos están constituídos principalmente por poblaciones de alto peso molecular y alto grado de esterificación con una distribución aleatoria de grupos metoxilo. El análisis de la composición química de la pectina extraída químicamente, indica la predominancia de galacturonanos, en particular homogalacturonanos, y una pequeña población neutra, probablente derivada de la hidrólisis de las cadenas laterales presentes en la región pilosa. PGI resultó altamente eficiente para macerar tejidos vegetales a $\mathrm{pH}$ 2.0, lo cual demuestra el potencial de la enzima de degradar sustratos insolubles a pH muy ácido.

\subsection{Introducción}

El uso de PGasas, en particular endo-PGasas, como auxiliares o coadyuvantes tecnológicos ha llegado a ser una práctica normal en la industria de alimentos, farmacéutica y textil 
[Voragen et al., 2001]. Dentro del área de procesado de frutas y verduras, las aplicaciones mas tradicionales de las PGasas son aquellas relacionadas con la clarificación de jugos y la desintegración de tejidos vegetales, particularmente en procesos de maceración y licuefacción (Capítulo 1). Otra importante aplicación, aún no llevada a nivel comercial, es la extracción de polisacáridos, entre ellos las sustancias pécticas, de residuos agroindustriales, plantas medicinales y otras fuentes vegetales. Comercialmente la pectina industrial se obtiene por extracción química a partir de bagazo (pomaza) de manzana o cáscaras de cítricos, ya que estos son residuos de bajo costo y contienen una alta proporción de sustancias pécticas [May, 1990]. Típicamente, la extracción se lleva a cabo con ácido para inactivar enzimas endógenas degradativas, prevenir la desesterificación (desmetoxilación) y la degradación alcalina que ocurre por beta eliminación. El método químico emplea ácidos fuertes (clorhídrico, sulfúrico o nítrico, $\mathrm{pH} 1.0$ a 3.0$)$, altas temperaturas $\left(80-95^{\circ} \mathrm{C}\right)$ y tiempos relativamente cortos de extracción (30-120 minutos). Los rendimientos a partir de residuos cítricos varían entre el 25 y $35 \%$ (g pectina/100 g de materia prima seca). La extracción ácida genera grandes problemas de efluentes y requiere el empleo de materiales resistentes a agentes corrosivos, lo cual aumenta los costos del proceso [Sakai et al., 1993]. El uso de ácidos débiles como agentes extractores, tales como cítrico y tartárico, es poco habitual debido a los bajos rendimientos y su alto costo. Sin embargo, existen reportes en literatura donde su efectividad de extracción es comparable a la de los ácidos fuertes [Pruthi, 1965; Rodríguez-Jasso, 2003]. Otros métodos de extracción de polisacáridos involucran el uso de procesos físicos, microbiológicos ó enzimáticos [Turakhodhaev and Khodzaev, 1993; Contreras-Esquivel et al., 1997; Hwang, 2001].

La extracción microbiológica y enzimática se conocen como métodos biológicos de extracción (Contreras-Esquivel et al., 1997). El término microbiológica se refiere al cultivo de microorganismos en medios conteniendo como sustrato la materia prima que es fuente de pectina. Si bien los rendimientos en escala de laboratorio son mínimamente aceptables (10 $\%$ ), el cambio de escala es dificultoso debido a las restricciones para transferir energía (mezclado, aireación) a medios muy viscosos (generados por la solubilización de las sustancias pécticas). La otra alternativa biológica es la enzimática. En este proceso se utilizan enzimas purificadas de origen microbiano o extractos enzimáticos crudos provenientes del cultivo de levaduras, bacterias u hongos filamentosos [Sakamoto and Sakai, 1994; Matora et al., 1995; Donaghy and Mckay, 1994]. El uso de extractos crudos está restringido cuando en el mismo están presentes actividades contaminantes que pueden degradar significativamente al polímero. En algunos casos, como ciertos cultivos de bacterias o levaduras, se han usado 
extractos sin purificación alguna, ya que el microorganismo por causas genéticas o culturales produce principalmente la enzima degradativa. La extracción de pectina por vía enzimática no necesariamente implica el uso exclusivo de enzimas pécticas, ya que se ha reportado el empleo conjunto de pectinasas con otras depolimerasas como celulasas o hemicelulasas, para potenciar el proceso extractivo [Choi and Cho, 2000]. Los rendimientos de pectina extraída por vía enzimática son variables y dependen del sustrato y tipo de enzima empleados. Se han reportado valores entre 10 y $35 \%$.

La extracción enzimática de pectina es un ejemplo clásico de reacción heterogénea. Este tipo de reacciones ha sido extensamente estudiada en sustratos como celulosa y hemicelulosa. La cinética del proceso depende de las propiedades de las enzimas (afinidad por el sustrato, inhibición por producto, estabilidad, etc.) y de la composición química y características estructurales del material. En los materiales celulósicos, parámetros tales como superficie específica, porosidad, distribución del volumen de poros y cristalinidad, determinan no solo la adsorción inicial de la enzima al sustrato sino también la velocidad y extensión de la reacción de hidrólisis [Mansfield et al., 1999]. A diferencia de las reacciones catalizadas por celulasas, muy poco se ha estudiado sobre las reacciones heterogéneas catalizadas por pectinasas [Cavalitto et al., 1997].

Cuando se determinó la actividad de PGI sobre diferentes protopectinas (el sustrato empleado para medir actividad PPasa), se observaron diferencias importantes en la velocidad inicial de hidrólisis del sustrato. Resultó por lo tanto interesante determinar algunos parámetros fisico-químicos de las protopectinas y establecer alguna relación entre dichos parámetros y la degradabilidad química y enzimática del material. Por otra parte y teniendo en cuenta la capacidad de PGI para degradar sustratos insolubles en condiciones de alta acidez, se investigó el empleo de la enzima para extraer pectina de un sustrato industrial como es la pomaza de limón y para macerar tejidos vegetales. Con fines comparativos se efectuaron además extracciones químicas y extracciones enzimáticas con la PGasa de A. niger, en este último caso a $\mathrm{pH}$ 4.5. Los extractos se analizaron por métodos químicos y cromatográficos. En el presente Capítulo se presentan los resultados de dichos estudios.

\subsection{Materiales y métodos}

\subsubsection{Reactivos químicos y materiales}

Las enzimas empleadas para los estudios de extracción de pectina fueron: PGI de A. kawachii, PGasa de A. niger (Megazyme) y extractos crudos de cultivos de A. kawachii en medio glucosa o pomaza de limón (PL). Los medios fueron filtrados por tela muselina, 
centrifugados y liofilizados. El sólido obtenido se resuspendió a una concentración $10 \times$ con agua y se pasó por una columna PD-10 para eliminar compuestos de bajo peso molecular (ver Capítulo 2 de la presente Tesis). La pomaza de limón (PL) empleada fue la descripta en 2.2.2. En este caso el material triturado fue separado mediante tamices utilizando la fracción que pasa la malla 40 y se retiene en malla 50. El etanol fue obtenido de Soria (Argentina) y la acetona de Anal Quim (Argentina).

\subsubsection{Preparación y análisis de protopectinas de albedo de limón}

Para la preparación de las diferentes protopectinas se utilizaron limones (Citrus limon Burm) provenientes de la localidad de San Pedro (Provincia de Buenos Aires, Argentina). Se utilizaron tres procedimientos de preparación con el objetivo de disponer de sustratos con diferentes propiedades. En todos los casos la obtención del albedo fue la siguiente: los limones fueron lavados, secados, seleccionados manualmente y mantenidos durante toda la noche bajo refrigeración. Luego fueron puestos en recipientes de plástico y cubiertos con hielo para minimizar reacciones enzimáticas endógenas. El flavedo y albedo fueron retirados manualmente de manera secuencial con la ayuda de un cuchillo; primero el flavedo y luego el albedo. El rendimiento fue de $100 \mathrm{~g}$ albedo húmedo/kg de limón. Con el albedo obtenido se efectuaron los siguientes tratamientos:

Método 1: Tratamiento con etanol frío [Cavalitto et al., 1997]. En este método el albedo durante su extracción del limón fue mezclado con etanol frío en una relación 1:4 (albedo:etanol). Una vez procesado todo el material la mezcla se filtró y el sólido se trituró mecánicamente con un procesador de alimentos (Dinamatic, Industria Argentina). El material fue luego suspendido en agua y tamizado en húmedo recuperando la fracción que pasa por malla 16 y se retiene en malla 20. El albedo húmedo y tamizado fue mezclado nuevamente con etanol frío dentro de un recipiente de plástico en una relación 1:4 (albedo: etanol) y mantenido en esas condiciones $12 \mathrm{~h}$ en refrigeración. El objetivo de este tratamiento fue inactivar la PME endógena. Al término de esta operación, la mezcla se filtró a través de tela muselina y se lavó con agua corriente a temperatura ambiente hasta eliminar sustancias pécticas solubles en agua (medidas como ácido galacturónico). El tiempo de lavado dependió de la cantidad de material procesado, oscilando entre 24 y 36 h. Finalizado el lavado, el material se deshidrató tratándolo con etanol y luego con acetona. El solvente se eliminó a temperatura ambiente. El rendimiento final del proceso fueron $80 \mathrm{~g}$ de albedo seco/ $\mathrm{kg}$ de albedo húmedo ó 0.8 \% en base a limón fresco. El material seco fue tamizado seleccionándose finalmente la fracción que pasa malla 40 y es retenida por malla 50 . 
Método 2: Tratamiento con etanol caliente [Voragen et al., 1980; Renard, 1988] El albedo extraído del limón se mezcló con dos partes de etanol dentro de un matraz bola y se calentó a reflujo $\left(80^{\circ} \mathrm{C}\right)$ en un rotavapor (Büchi) durante 20 minutos. El material una vez frío se filtró a través de tela muselina y se continuó con el procedimiento descrito anteriormente es decir se resuspendió en agua y tamizó en húmedo, lavó con agua hasta desaparición de AGA soluble, deshidrató con solventes y finalmente se tamizó en seco recogiendo la fracción que pasa malla 40 y es retenida por malla 50. El material obtenido por este procedimiento se denominó material insoluble en etanol (AIS).

Método 3: Tratamiento con buffer fosfato y NaCl. Este tratamiento tuvo como objetivo eluir las enzimas endógenas del albedo, en particular la PME. El procedimiento final que se describe fue establecido luego de varios ensayos en los cuales se determinó el efecto de la concentración de $\mathrm{NaCl}$, tiempo de incubación y número de lavados del sólido en la elución de la enzima. El tratamiento fue el siguiente: se mezclaron 6 partes de buffer fosfato de sodio 0.1 M, pH 7.0 conteniendo $0.25 \mathrm{M}$ de $\mathrm{NaCl}$ con una parte de albedo, la mezcla se agitó 4 horas bajo refrigeración y luego el albedo se separó por filtración a través de tela muselina. Esta operación se repitió cuatro veces. Luego de la última filtración, se continuó con el procedimiento descrito anteriormente, es decir el material se tamizó en húmedo, lavó con agua, deshidrató con solventes y finalmente se tamizó en seco recogiendo la fracción que pasa malla 40 y es retenida por malla 50. En la Tabla 4.1 se presentan las protopectinas preparadas por los diferentes métodos.

Tabla 4.1. Protopectinas de limón.

\begin{tabular}{cccl}
\hline Código & $\begin{array}{c}\text { Lote de } \\
\text { limón }\end{array}$ & $\begin{array}{c}\text { Método de } \\
\text { preparación }\end{array}$ & \multicolumn{1}{c}{$\begin{array}{c}\text { Referencia método de } \\
\text { preparación }\end{array}$} \\
\hline M1 & 1 & 1 & Cavalitto et al. [1997] \\
M2 & 2 & 1 & Cavalitto et al. [1997] \\
M3 & 3 & 2 & Este estudio \\
M4 & 3 & 1 & Cavalitto et al. [1997] \\
M5 & 3 & 3 & Voragen et al. [1980] \\
\hline
\end{tabular}

Composición de azúcares: el análisis de la composición de azúcares de las protopectinas se realizó según los métodos descriptos en el Capítulo 2 (sección 2.2.5.1.).

Grado de esterificación: el contenido de grupos metoxilo se evaluó por el método de hidrólisis química propuesto por Woody and Siddiqui [1971].

Actividad PME: la presencia de esta enzima en protopectina se determinó por un método cualitativo. A tal fin se incubaron en un tubo de ensayo $5 \mathrm{mg}$ de material con un mililitro de 
pectina al $1 \%$ y rojo de metilo como indicador durante 4 horas a $37^{\circ} \mathrm{C}$. La actividad de PME se detectó al virar el indicador [Versteeg, 1979]. Otro método empleado consistió en eluir la PME con buffer y determinar la gelificación de una solución de pectina luego de incubar dicho sustrato con el extracto. Esta alternativa es más sensible que el método colorimétrico y se aplicó a determinar la presencia de PME en la pomaza de limón. En este caso, $5 \mathrm{~g}$ de pomaza de limón se incubaron con agitación durante $4 \mathrm{~h} \mathrm{a} 4^{\circ} \mathrm{C}$ con $120 \mathrm{ml}$ de buffer Tris- $\mathrm{HCl}$ $0.1 \mathrm{M}$, pH 7.5 conteniendo $0.25 \mathrm{M}$ de $\mathrm{NaCl}$. Luego de la incubación, la mezcla se filtró y la actividad PME se determinó en el filtrado por el método cualitativo de gelificación. Para el test se mezcló un volumen de filtrado con un volumen de solución de pectina al $1 \%(\mathrm{p} / \mathrm{v})$ en

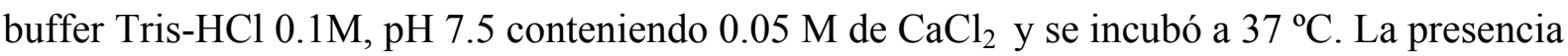
de actividad PME se evidencia por la gelificación de la solución.

Estabilidad de las protopectinas: para determinar el efecto del $\mathrm{pH}$ y la temperatura en la estabilidad de las protopectinas, se incubaron mezclas conteniendo $20 \mathrm{mg}$ de material y un $\mathrm{ml}$ de BCP, pH final 2.0, 3.0 y 5.0, durante 60 minutos a diferentes temperaturas: 0,37 y $50{ }^{\circ} \mathrm{C}$. Al término de la incubación los tubos fueron puestos en baño de hielo durante 10 minutos y el material soluble separado de la fase sólida mediante filtración a través de papel de filtro (Whatman $\mathrm{N}^{\mathrm{o}}$ 1). En el filtrado se determinó ácido galacturónico por el método del metahidroxidifenilo [Blumenkrantz and Asboe-Hansen, 1972].

Capacidad de hinchamiento: la capacidad de hinchamiento $(\mathrm{CH})$ indica la capacidad del producto para aumentar su volumen en presencia de un exceso de agua [Baquero y Bermúdez, 1998]. Se determinó colocando protopectina en una probeta de $10 \mathrm{ml}$ de capacidad de manera tal de completar $1 \mathrm{ml}$ de volumen de sólido y registrando su peso. Luego se agregó un exceso de buffer citrato $20 \mathrm{mM}$, pH 2.0 y se determinó el volumen del sólido luego de 24 horas de incubación a $25^{\circ} \mathrm{C}$ en reposo. $\mathrm{La} \mathrm{CH}$ fue determinada con la siguiente formula:

$$
\mathrm{CH}=[\mathrm{Vf}(\mathrm{ml})-\mathrm{Vo}(\mathrm{ml}) / \text { peso de la muestra }(\mathrm{g})]
$$

Vf: volumen final del sólido, Vo: volumen inicial

Color: el color de las protopectinas fue analizado con un fotocolorímetro Minolta ${ }^{\circledR}$. Se utilizó el sistema $L$ (luminosidad), $a$ (rojizo), - $a$ (verdoso), $b$ (amarillento) y - $b$ (azulado).

Isotermas de adsorción y desorción de agua: Para la construcción de las isotermas de adsorción, las muestras de protopectina y pomaza de limón fueron secadas a $70^{\circ} \mathrm{C}$ durante 24 horas y luego se expusieron en un desecador a diferentes condiciones de humedad relativa a $20^{\circ} \mathrm{C}$ [Fu et al., 1990]. La variación de humedad relativa fue lograda utilizando soluciones concentradas de ácido o soluciones saturadas de diferentes sales [Handbook of Chemistry and 
Physics, 1976-1977], según el detalle de la Tabla 4.2. Para la construcción de las curvas de desorción las muestras fueron expuestas a valores de humedad relativa decrecientes. El contenido de humedad de las muestras se expresa en $\mathrm{g}_{2} \mathrm{O} / \mathrm{g}$ de materia seca. En general para cada condición, el equilibrio se obtuvo dentro de las 48-72 h.

Cálculo de la superficie específica $\left(S_{\text {esp }}\right)$ : Para las protopectinas M1 y M3 se calcularon valores de $\mathrm{S}_{\mathrm{esp}}$ mediante porosimetría de nitrógeno [Panchev and Karageorgiev, 2000].

Los valores de $\mathrm{S}_{\mathrm{esp}}$ se calcularon también a partir de las isotermas de adsorción de agua, según la siguiente ecuación:

$$
\mathrm{S}_{\mathrm{esp}}=\mathrm{G}_{\mathrm{ads}} \times \mathrm{N} \times \mathrm{A} \times 10^{-18} /\left(\mathrm{G}_{\mathrm{m}} \times \mathrm{PM}\right) \quad \text { ecuación } 4.1
$$

S: superficie específica $\left(\mathrm{m}^{2} / \mathrm{g}\right), \mathrm{G}_{\text {ads }}$ : gramos de adsorbato adherido a la superficie, $\mathrm{N}$ número de Avogadro, A: área de la molécula de adsorbato, $10^{-18}$ : factor de conversión de $\mathrm{nm}^{2} \mathrm{a} \mathrm{m}^{2}$, $\mathrm{G}_{\mathrm{m}}$ : gramos de material, PM: peso molecular del adsorbato.

De la ecuación anterior y siendo $\mathrm{K}=3545 \mathrm{si}$ el adsorbato es agua, tenemos

$$
\mathrm{S}_{\mathrm{esp}}=\left(\mathrm{G}_{\mathrm{ads}} / \mathrm{G}_{\mathrm{m}}\right) \times \mathrm{K} \quad \text { ecuación } 4.2
$$

$\left(\mathrm{G}_{\mathrm{ads}} / \mathrm{G}_{\mathrm{m}}\right)$ es el contenido de humedad del sólido para un valor de humedad relativa seleccionada.

Tabla 4.2. Valores de humedad relativa en equilibrio a $20^{\circ} \mathrm{C}$ de distintos compuestos y soluciones saturadas.

\begin{tabular}{lc}
\hline \multicolumn{1}{c}{ Compuesto o solución } & P/Po a 20 ${ }^{\circ} \mathbf{C}$ \\
\hline $\mathrm{P}_{2} \mathrm{O}_{5}$ sólido & 0,00 \\
$\mathrm{H}_{2} \mathrm{SO}_{4} \quad 69,09 \% \mathrm{~d}=1,60$ & 0,09 \\
$\mathrm{H}_{2} \mathrm{SO}_{4} \quad 60,17 \% \mathrm{~d}=1,57$ & 0,20 \\
$\mathrm{H}_{2} \mathrm{SO}_{4} 50,50 \% \mathrm{~d}=1,30$ & 0,37 \\
$\mathrm{KSCN}^{*}$ & 0,47 \\
$\mathrm{Ca}\left(\mathrm{NO}_{3}\right)_{2} \cdot 4 \mathrm{H}_{2} \mathrm{O} *$ & 0,56 \\
$\mathrm{NaNO}_{2} *$ & 0,66 \\
$\mathrm{NaCH}_{3} \mathrm{COO} .3 \mathrm{H}_{2} \mathrm{O} *$ & 0,76 \\
$\mathrm{KCl}^{*}$ & 0,86 \\
$\mathrm{CuSO}_{4} \cdot 5 \mathrm{H}_{2} \mathrm{O} *$ & 0,98 \\
$\mathrm{H}_{2} \mathrm{O}$ pura & 1,00 \\
\hline
\end{tabular}




\subsubsection{Degradación enzimática de protopectinas}

La degradación de las protopectinas por vía enzimática se determinó midiendo la actividad PPasa que corresponde a medidas de velocidad inicial de solubilización del material péctico, según se describió en el Capítulo 2 (sección 2.2.5.2).

\subsubsection{Extracción de pectina a partir de protopectina de albedo de limón con PGI}

La extracción de material péctico de protopectina se realizó en tubos de vidrio $(14.50 \mathrm{~mm}$ de diámetro interno) con $30 \mathrm{mg}$ de protopectina $\mathrm{M} 1$ y $1.5 \mathrm{ml}$ de $\mathrm{BCP}\left(\mathrm{pH}_{\text {mezcla }}=2.0-2.2\right)$. La cantidad de PGI agregada fue de $1.25 \mu \mathrm{g} / \mathrm{g}$ de sustrato que equivale a una concentración de $0.025 \mu \mathrm{g} / \mathrm{ml}$ de enzima en la mezcla final de reacción. Como control se empleó una muestra con buffer sin enzima. Los tubos fueron puestos en baño de hielo durante 10 minutos y luego de agregar la enzima se colocaron en un baño termostatizado equipado con un sistema de agitación recíproca a 37 ó $50^{\circ} \mathrm{C}$ durante un tiempo total de reacción de $24 \mathrm{~h}$. A intervalos prefijados, se retiraron muestras (un tubo por muestra $\times$ duplicado) y se enfriaron rápidamente en baño de hielo. La separación de la fase líquida de la fase sólida fue efectuada con una punta de pipeta de $5 \mathrm{ml}$ recortada en el extremo y cubierta con tela muselina para filtrar la mezcla bajo succión con la ayuda de una micropipeta. Una vez obtenido el filtrado una parte del mismo se mezcló con dos volúmenes de etanol y se incubó durante 2 horas a $5{ }^{\circ} \mathrm{C}$, luego de lo cual se centrifugó $\left(10000\right.$ g x 30 minutos a $\left.4^{\circ} \mathrm{C}\right)$ descartándose el sobrenadante. Esta operación fue repetida dos veces más con el propósito de eliminar los oligómeros y monómeros, es decir la fracción no precipitable con etanol [Dongowski and Lorenz, 1998]. El pellet fue finalmente resuspendido en agua a un volumen conocido. La extracción de material péctico fue evaluado midiendo el contenido de AGA en el filtrado y en la fracción insoluble en etanol. Esta última corresponde al material polimérico.

\subsubsection{Extracción de pectina a partir de pomaza de limón con PGI}

Los ensayos de extracción de pectina de pomaza de limón con PGI se efectuaron en erlenmeyers de $50 \mathrm{ml}$ conteniendo $500 \mathrm{mg}$ de PL, $12 \mathrm{ml}$ de BCP pH 1.85 (pH final de la mezcla 2.0-2.1) y $20 \mu \mathrm{l}$ de enzima diluida apropiadamente en BCP. La cantidad de PGI agregada fue de $11.5 \mu \mathrm{g} / \mathrm{g}$ de sustrato que equivale a una concentración de $0.5 \mu \mathrm{g} / \mathrm{ml}$ de enzima en la mezcla final de reacción. Para la extracción primero se diluyó la enzima en el buffer y luego se adicionó la pomaza seca a cada matraz con el objetivo de facilitar la adsorción de la enzima al sólido debida a la imbibición del sustrato. La mezcla se incubó en un shaker recíproco durante 2 horas a $37^{\circ} \mathrm{C}$. Luego el material fue filtrado a través de tela muselina. La fracción sólida retenida (pomaza despectinizada) fue lavada con agua destilada y 
deshidratada con etanol y acetona. El solvente se eliminó a $50^{\circ} \mathrm{C}$. El material obtenido fue pesado y envasado en recipientes de vidrio herméticos. El filtrado una vez obtenido se calentó a ebullición 5 min para inactivar a la enzima, se mezcló con 2 volúmenes de etanol y se mantuvo toda la noche bajo refrigeración para precipitar el material polimérico. Este fue recuperado mediante centrifugación a $6500 \mathrm{rpm}$ durante 30 minutos y luego secado en estufa a $40{ }^{\circ} \mathrm{C}$. El material seco se disolvió en agua y liofilizó. El propósito de esta operación fue la de obtener un material de disolución fácil y rápida en agua.

\subsubsection{Extracción de pectina a partir de pomaza de cáscara de limón con endo-PG de $A$. niger}

Debido a una mayor disponibilidad de la PGasa de A. niger, la extracción de pectina con esta enzima se realizó en una escala mayor. A tal fin se empleó un reactor de vidrio encamisado con agitación magnética. Se utilizaron $120 \mathrm{ml}$ de BCP ( $\mathrm{pH} 4.5)$ y 5 g de PL. La cantidad de PGasa agregada fue de $1.6 \mu \mathrm{g}$ (proteína)/g de sustrato que equivale a una concentración de $0.07 \mu \mathrm{g} / \mathrm{ml}$ de proteína en la mezcla final de reacción. La reacción fue conducida durante $12 \mathrm{~h}$ a $37^{\circ} \mathrm{C}$. El procesamiento de las muestras fue similar al descripto anteriormente para PGI.

\subsubsection{Extracción química de pectina a partir de pomaza de limón}

La extracción química de pectina fue llevada a cabo por el procedimiento descripto por Royo-Iranzo et al. [1975]. La metodología consistió en suspender 5 g de pomaza de limón en $120 \mathrm{ml}$ de agua destilada, ajustar el pH a 2.0 con ácido clorhídrico, calentar la mezcla a una temperatura de $90^{\circ} \mathrm{C}$ durante 60 minutos, enfriar y luego separar la fase líquida mediante ligera presión a través de tela muselina. El procesamiento del filtrado y el residuo sólido fue similar al descripto anteriormente para PGI.

\subsubsection{Análisis de las pectinas extraídas}

Cromatografía de tamiz molecular (CTM) Se utilizó para determinar la distribución de peso molecular. Se empleó un sistema HPLC con cuatro columnas en serie, PWXL 50, 40, 30 y 25; Bio-Gel, 300 x $7.8 \mathrm{~mm}$ (Tosohaas, Stuttgart, Alemania), en combinación con una columna guarda para protección TSK XL $(40 \times 6 \mathrm{~mm})$ a $35^{\circ} \mathrm{C}$. El volumen de muestra fue de $300 \mu \mathrm{l}$ (conteniendo $\sim 0.6-1.5 \mathrm{mg}$ de producto). Como buffer de elución se empleó acetato de sodio $0.4 \mathrm{M} \mathrm{pH} 3.8$ a un caudal de $0.8 \mathrm{~mL} / \mathrm{min}$. La concentración de AGA y azúcares neutros en el 
eluído fue determinada continuamente a través del método automatizado del mhidroxidifenilo [Thibault, 1979] y orcinol [Tollier and Robin, 1979] respectivamente, usando un auto-analizador (Alliance Instruments, Méry/Oise, Francia).

Cromatografía de intercambio aniónica (CIAN) La densidad de carga de las pectinas fue caracterizada mediante la CIAN utilizando una columna TSK DEAE 5PW (75 x 7.5 mm, Toyosoda, Japón) acoplada a un equipo HPLC. La columna se equilibró con buffer acetato de amonio $0.05 \mathrm{M}$ pH 6.0. La elución de la muestra se efectuó con el buffer de equilibrio seguido de un gradiente de acetato de amonio 0.05-0.5 M, pH 6.0. El caudal operativo fue de 0.6 $\mathrm{ml} / \mathrm{min}$. El volumen de muestra fue de $300 \mu \mathrm{l}$ (conteniendo 0.6-1.5 mg de producto). El eluído fue analizado como se describió para la CTM.

Cromatografía de intercambio aniónica (CIAN) preparativa. La CIAN preparativa fue realizada con una columna de DEAE-Sepharose CL-6B $(40 \times 2.5 \mathrm{~cm})$ acoplada a un HPLC. La columna fue equilibrada con buffer acetato de amonio $0.01 \mathrm{M} \mathrm{pH}$ 6.0. La muestra fue eluída con buffer de equilibrio seguido por un gradiente de acetato de amonio $0.01-1 \mathrm{M} \mathrm{pH}$ 6.0. El caudal fue de $2.5 \mathrm{ml} / \mathrm{min}$. La cantidad de muestra cromatografiada fue de $100 \mathrm{mg}$. El eluído fue evaluado continuamente como se describió en la CTM. Las fracciones recolectadas fueron dializadas contra agua y liofilizadas. Las muestras fueron analizadas en cuanto a su contenido de ácido galacturónico y azúcares neutros según el método descripto en el Capítulo 2 (sección 2.2.5.1).

\subsubsection{Analisis infrarojo con transformada de Fourier (FTIR)}

Los análisis de protopectinas y pectinas fueron llevados a cabo en un equipo FTIR (Spectrum GX, Perkin Elmer) y con un accesorio atenuador de reflactancia total (ART, SensIR, Parte número: 071-1305) de punta de oro. Los espectros fueron registrados en la región espectral de $4000-670 \mathrm{~cm}^{-1}$. Los espectros fueron registrados por 35 escaneos a un resolución de $4.0 \mathrm{~cm}$ 1. Los espectros fueron corregidos en su línea base y normalizados tangencialmente con el programa Opus (Version 4.0, Bucker, Alemania).

\subsubsection{Maceración de tejidos vegetales}

Para los estudios de maceración se emplearon zanahorias (Daucus carota L.), pimientos (Capsicum annuum L.) y frutillas (Fragaria ananassa Duch) de la región frutihortícola de la La Plata (Pcia de Buenos Aires, Argentina) adquiridos en septiembre/octubre del 2001. Todos los materiales fueron lavados con agua destilada. Las zanahorias y las frutillas fueron cortadas transversalmente y luego se hicieron extracciones del floema con un horadador de laboratorio 
( $5 \mathrm{~mm}$ de diámetro). Los cilindros obtenidos fueron luego cortados a una longitud de $5 \mathrm{~mm}$. Los pimientos fueron cortados de igual manera. Las zanahorias y pimientos fueron escaldados a vapor durante 5 minutos para inactivar enzimas endógenas y disminuir la carga microbiana. La frutilla no fue escaldada debido a la pérdida de textura. Los ensayos de maceración se realizaron en erlenmeyers de $50 \mathrm{ml}$ conteniendo 2.2 gramos de material y 7.5 $\mathrm{ml}$ de $\mathrm{BCP}(1 / 2)$ al $\mathrm{pH}$ indicado. En caso de ser necesario el $\mathrm{pH}$ final de la mezcla fue reajustado con $\mathrm{HCl}$ o $\mathrm{NaOH}$. Los ensayos de maceración se efectuaron con PGI, extractos de los cultivos de A. kawachii en medio glucosa y pomaza de limón (ver sección 4.2.1) o PGasa de A. niger según se lo indica en el texto. La cantidad de PGI agregada fue de $2.6 \mu \mathrm{g} / \mathrm{g}$ de sustrato que equivale a una concentración de $0.76 \mu \mathrm{g} / \mathrm{ml}$ de enzima en la mezcla final de reacción. En los ensayos con los medios se agregó $100 \mu 1$ de extracto en la mezcla de reacción (equivalente a una dilución 1:7.5 del medio de cultivo original). Los ensayos con zanahoria y pimiento fueron de $8 \mathrm{~h}$, agregándose en todos los casos azida de sodio al $0.01 \%$ como agente antimicrobiano. Para frutilla la maceración fue de $2 \mathrm{~h}$ y no se agregó azida de sodio. Como blanco se empleó un frasco sin enzima. Luego de agregar la enzima a los sustratos termostatizados, los frascos se agitaron moderadamente (100 strokes $/ \mathrm{min})$ a $37^{\circ} \mathrm{C}$. Para evaluar la maceración, el contenido total del frasco se filtró a través de malla 50 con ayuda de un embudo plástico. El filtrado se recolectó en tubos cónicos de vidrio graduados de $10 \mathrm{ml}$ y se mantuvo 12 horas bajo refrigeración. Al término de este tiempo se determinó el volumen total de líquido (Vt) y el volumen de compactación celular $(\mathrm{Vc})$. El Vt y Vc fueron relacionados cualitativamente con la actividad macerante. La observación microscópica de los filtrados fueron efectuados con un microscopio de contraste de fase equipado con cámara fotográfica Karl Zeizz.

\subsection{Resultados}

\subsubsection{Caracterización fisico-química de las protopectinas}

En la Tabla 4.3 se presentan los datos de composición química y algunas otras características de las protopectinas. Con fines comparativos se incluye la composición de PL (Capítulo 2). Todas las muestras fueron estandarizadas a una misma distribución de tamaño de partícula por tamización, por lo que este parámetro es común a todas ellas. Las diferentes protopectinas muestran una composición similar en azúcares neutros y en AGA, representando este último aproximadamente el $45 \%$ de los azúcares totales. En el caso de PL, este material industrial contiene tanto albedo como flavedo y otras impurezas, pero la composición en general es comparable al de las protopectinas (100\% albedo). La mayor 
diferencia en la composición química reside en el grado de esterificación (metoxilación, GM). Las protopectinas M2 y M3 presentan un bajo GM, M1 y M4 intermedio y M5 es la mas esterificada. Esta diferencia en GM es atribuible a la activación de la PME durante el procesamiento del albedo, ya que varios ensayos de estabilidad de pectina cítrica en BCP, en los cuales se varió el pH (2.0 a 5.0), temperatura $\left(0\right.$ a $\left.37^{\circ} \mathrm{C}\right)$ y tiempo de incubación $(2$ a 24 h), mostraron que la desesterificación no enzimática bajo estas condiciones es negligible. La protopectina M5 fue tratada con etanol caliente para inactivar la PME; esto indica que este método es el más apropiado para conservar el grado de esterificación en materiales modelo de pared celular vegetal. En el caso de M3 la enzima se eluyó con una solución extractiva, sin embargo durante el proceso de elución, la PME evidentemente desesterificó el sustrato; por consecuencia este método no resultó apropiado para preparar protopectina con alto grado de esterificación. La presencia de actividad PME residual en el resto de los materiales muestra claramente que los tratamientos con etanol en frío no inactivan completamente la enzima y que existen variaciones aún con igual procedimiento de preparación. Cabe destacar que en la preparación de M2, el material fue lavado con agua por un período mayor comparado con M1 y M4, lo cual evidentemente permitió una mayor acción de la PME dando como resultado una protopectina de bajo GM.

Tabla 4.3. Propiedades físico-químicas de protopectinas de limón.

\begin{tabular}{lcccccc}
\hline & \multicolumn{7}{c}{ Protopectinas } \\
\cline { 2 - 7 } \multicolumn{1}{c}{ Descripción } & M1 & M2 & M3 & M4 & M5 & PL* \\
\hline Azúcares (mg/g)* & & & & & & \\
Acido galacturónico (AGA) & 344 & 295 & 335 & 334 & 325 & 296 \\
Glucosa & 208 & 166 & 183 & 184 & 173 & 180 \\
Arabinosa & 90 & 70 & 77 & 70 & 63 & 74 \\
Galactosa & 38 & 36 & 30 & 29 & 26 & 54 \\
Manosa & 25 & 18 & 20 & 20 & 19 & 22 \\
Xilosa & 31 & 25 & 30 & 29 & 25 & 25 \\
Ramnosa & 10 & 15 & 7 & 8 & 7 & 6 \\
Fucosa & 2 & 3 & 3 & 3 & 3 & 3 \\
GE (\%) & 57.7 & 19.6 & 11.9 & 44.2 & 71.0 & 58 \\
Actividad residual PME & ++ & + & - & +++ & - & + \\
CH (ml/g) & 7.9 & - & 2.8 & 5.2 & 8.0 & - \\
Densidad aparente (g/ml) & 0.2 & 0.36 & 0.25 & 0.25 & 0.45 & - \\
Color & & & & & & \\
$\quad L$ & 92.05 & 71.78 & 90.74 & 86.49 & 77.70 & - \\
$a$ & +2.00 & -0.87 & -1.53 & -0.95 & -0.10 & - \\
$b$ & 10.10 & 12.84 & 11.08 & 12.19 & 18.20 & - \\
\hline
\end{tabular}

* en base seca. Las muestras contienen en promedio $10 \%$ de humedad. $\mathrm{CH}$ : capacidad de hinchamiento determinada en buffer citrato $20 \mathrm{mM}$, pH 2.0 a $20^{\circ} \mathrm{C}$; GE: grado de esterificación. * Pomaza de limón 
La sobre exposición de M2 a las condiciones ambientales se puede visualizar también en la menor luminosidad que presenta, la cual puede atribuirse a reacciones de oxidación. La oxidación de los tejidos vegetales puede afectar severamente las propiedades del material pues genera compuestos polifenólicos que forman agregados con los polisacáridos y de este modo modifican su degradabilidad química y enzimática así como también sus propiedades hídricas [Massiot and Renard, 1987].

En las reacciones enzimáticas heterogéneas las características físicas relacionadas con la macro y microestructura del sustrato determinan en gran parte su degradabilidad. En este trabajo las características estructurales de las protopectinas se evaluó a través de sus propiedades de hidratación. Los datos sobre las propiedades de hidratación dependen mucho del método empleado para su evaluación. Para caracterizar las protopectinas se determinaron isotermas de adsorción de agua y la capacidad de hinchamiento $(\mathrm{CH})$. En el primer caso se determinan condiciones de hidratación a valores de humedad relativa (HR) por debajo de la saturación. Las isotermas proveen información útil relacionada con $\mathrm{S}_{\mathrm{esp}} \mathrm{y}$ la porosidad del material. En el segundo caso se evalúa la máxima capacidad de expansión del material bajo condiciones de exceso de agua que es generalmente la condición en que ocurre la reacción enzimática.

En la Figura 4.1A se muestran las isotermas de adsorción de agua para las distintas potopectinas analizadas.
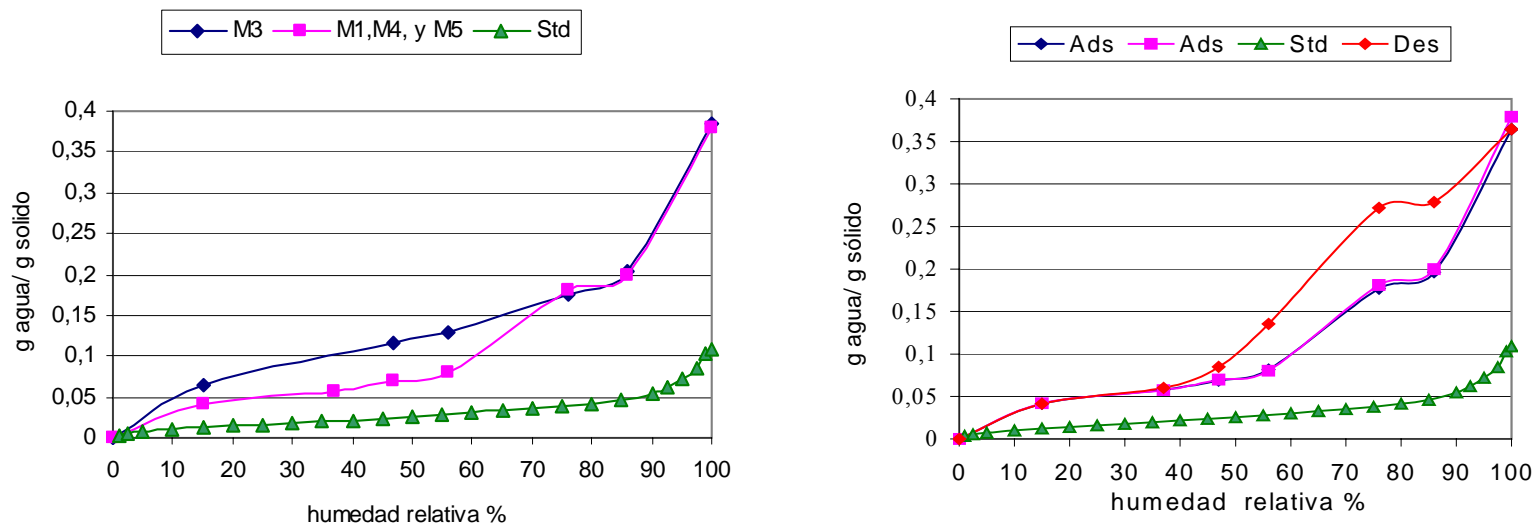

Figura 4.1. Isotermas de adsorción de agua de protopectinas (A) y de adsorción-desorción (B) de pomaza de limón a $20^{\circ} \mathrm{C}$.

Se observa que las isotermas de adsorción de agua para las muestras M1, M4 y M5 y PL son similares, en pasos y alcanzan la saturación a valores de humedad relativa de 56 y $86 \%$ con un valor de adsorción de agua que se encuentra alrededor de 0.08 y $0.19 \mathrm{~g}$ de agua/g de 
muestra seca, respectivamente. Estos pasos o escalones se relacionan con la saturación de los micro y mesoporos del material. Los microporos se llenan primero es decir en la zona de menor HR seguido luego de los mesoporos. A valores de HR > del $86 \%$ el agua se encuentra libre y la isoterma refleja efectos capilares y de solución. El contenido de agua a $100 \%$ de HR es de $\sim 0.4 \mathrm{~g}$ agua/g muestra seca. La isoterma de M3 se diferencia del resto en la zona de baja HR. La muestra capta mas cantidad de agua a igual HR, lo que sugiere una mayor microporosidad del material. Si bien la primer meseta es difusa, la segunda meseta se alcanza al mismo valor de HR y contenido de agua que las demás protopectinas. Las isotermas basadas en la adsorción de agua se han empleado para calcular la superficie específica $\left(\mathrm{S}_{\mathrm{esp}}\right)$ del sólido en lugar de la clásica porosimetría de mercurio o nitrógeno, ya que estas moléculas por ser no polares no pueden penetrar en los microporos del sólido y de este modo se subestima en varios órdenes de magnitud el valor de $S_{\text {esp. }}$ [Hagymassy et al,. 1969] . Esta situación sería extrapolable a las protopectinas, pues estos son materiales con carga debido a la presencia de ácido galacturónico. Para confirmar esta situación se hicieron estimaciones de $\mathrm{S}_{\text {esp }}$ por porosimetría de nitrógeno obteniéndose para las muestras M1 y M3 valores de 1.2$1.3 \mathrm{~m}^{2} / \mathrm{g}$. Para el cálculo de $\mathrm{S}_{\mathrm{esp}}$ a partir de las correspondientes isotermas, se tomó el valor de humedad del sólido en el segundo escalón que corresponde a la saturación de los micro y mesoporos (ver ecuación 4.1). Los valores calculados fueron de $650-700 \mathrm{~m}^{2} / \mathrm{g}$, es decir 600 veces mayor que el valor obtenido por porosimetría de nitrógeno. Para PL se determinó también la isoterma de desorción (por evaporación) (Figura 4.1B). Se observa un ciclo de histéresis, con valores de equilibrio de humedad mayores cuando el equilibrio se establece por desorción (como es lo habitual). Esta histéresis es característica de los sólidos porosos que presentan heterogeneidad en la distribución de poros y es consistente con la información que brinda la forma de la isoterma. Sobre las bases de estos resultados podemos concluir que las protopectinas presentan un comportamiento semejante en relación a la hidratación, en particular en condiciones de altos valores de HR. Un resultado diferente se obtuvo cuando se determinó la capacidad de hinchamiento o swelling $(\mathrm{CH})$. Los valores de $\mathrm{CH}$ dependen de la solución acuosa en la cual se equilibra el material y es muy dependiente del tamaño de partícula. En este caso, $\mathrm{CH}$ se determinó en buffer cítrico a pH 2.0 para simular las condiciones en las cuales se hicieron las determinaciones de actividad y de extracción de pectina. Los valores de $\mathrm{CH}$ parecen correlacionar con el grado de metilación; a mayor GM mayor CH (Figura 4.2). 


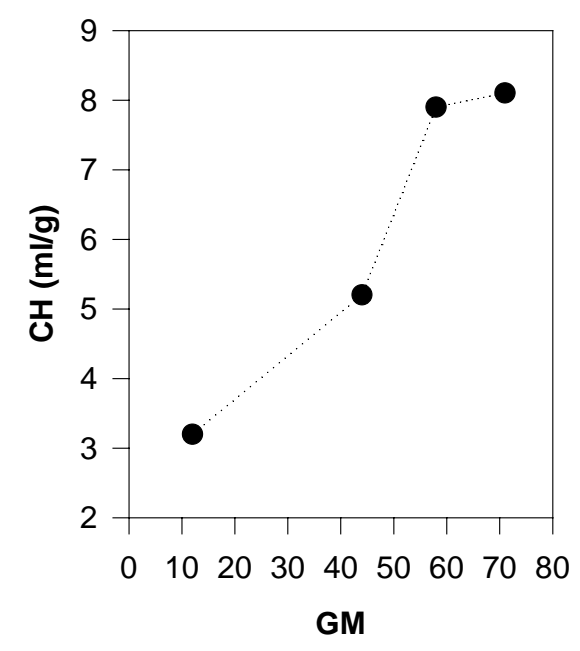

Figura 4.2. Relación entre el grado de metoxilacion (GM) y la capacidad de hinchamiento $(\mathrm{CH})$ de protopectinas de limón.

\subsubsection{Estabilidad química de las protopectinas}

Para conocer la estabilidad química de las protopectinas, se incubaron muestras a diferentes valores de $\mathrm{pH}$ y temperatura durante 60 minutos. Finalizada la incubación, la suspensión se filtró y en la fase soluble se determinó la presencia de AGA como indicador de solubilización de sustancias pécticas.

Los resultados obtenidos muestran una relación entre GM y la estabilidad química (Figura 4.3). A menor GM, menor solubilización independientemente del $\mathrm{pH}$ y la temperatura de incubación. Para todas las protopectinas la solubilización se incrementó con la temperatura y fue máxima a $\mathrm{pH} \leq 3.0$. Por el contrario la mayor estabilidad se encontró a bajas temperaturas y a pH 3.0. Cuando se incubaron soluciones de pectina (GM 53) en los mismos rangos de $\mathrm{pH}$ y temperatura, no se observó liberación de metanol, con lo cual podemos inferir que las protopectinas son también resistentes a la desesterificación en las condiciones de incubación estudiadas.

Para obtener información adicional sobre la estabilidad química de las protopectinas y su relación con GM, se realizó un ensayo de extracción de pectina con las muestras M3 y M5 (la mas esterificada, no empleada en el ensayo anterior) a pH 5.0 y 2.0. En el caso de M3 el tratamiento incluyó además muestras con hexametafosfato de sodio ( $\mathrm{HMNa}$ ) como agente quelante. Para incrementar la eficiencia, la extracción se efectuó en autoclave a $121{ }^{\circ} \mathrm{C}$ 
durante 5 minutos según lo descripto por Rodriguez-Jasso [2003]. Los resultados se detallan en la Tabla 4.4. Los datos confirman que en M3 existen restricciones a la solubilización de sustancias pécticas mientras que estas son fácilmente extractables de M5. Esto se visualiza claramente al comparar los tratamientos a pH 2.0 y 5.0 sin agente quelante. Con M3 a pH 5.0 la solubilización fue mínima, pero en presencia de HMNa se liberó una gran cantidad de pectina la cual gelificó inmediatamente (por tal motivo la determinación de AGA soluble es aproximada). A pH 2.0 el efecto del HMNa sobre M3 no se observó y la pectina extraída fue significativa aunque en mucha menor proporción que a pH 5.0 con HMNa.
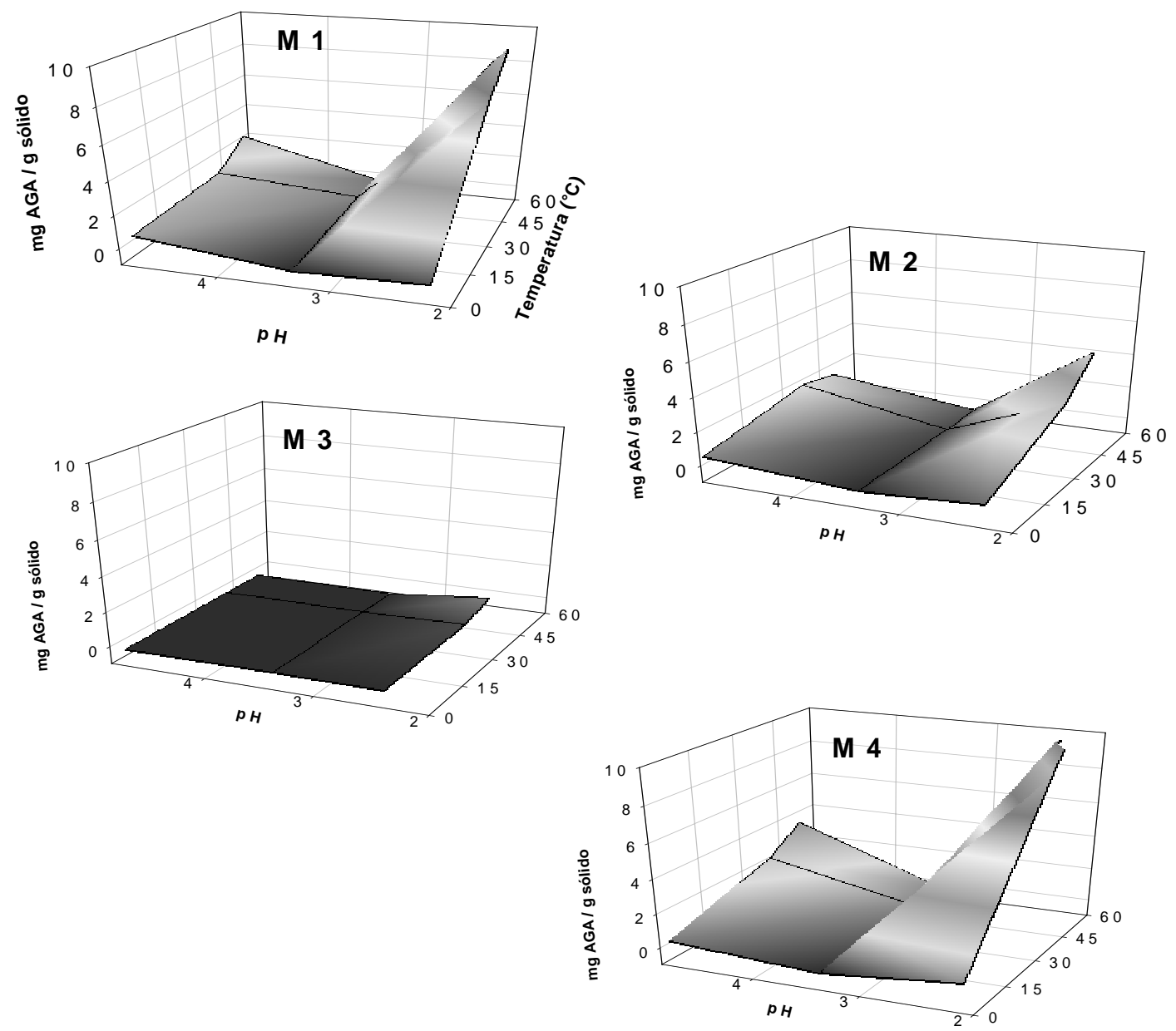

Figura 4.3. Efecto de la temperatura y $\mathrm{pH}$ sobre la liberación de AGA de protopectinas de limón (M1, M2, M3, y M4). Incubación 60 minutos. 
Tabla 4.4. Liberación de AGA por autoclavado de protopectina.

\begin{tabular}{cccc}
\hline Protopectina & $\begin{array}{c}\text { pH de } \\
\text { autoclavado }\end{array}$ & $\begin{array}{c}\text { Presencia de } \\
\text { HMP* }\end{array}$ & $\begin{array}{c}\text { \% AGA } \\
\text { soluble }\end{array}$ \\
\hline M5 & 2 & $\cdot$ & 34.0 \\
M5 & 5 & $\cdot$ & 24.0 \\
M3 & 2 & - & 8.40 \\
M3 & 2 & + & 8.84 \\
M3 & 5 & - & 1.66 \\
M3 & 5 & + & $>30.0$ \\
\hline
\end{tabular}

*HMP $=$ Hexametafosfato de sodio al $2 \%$ durante el autoclavado

\subsubsection{Acción de PGI sobre protopectina}

La susceptibilidad de las diferentes protopectinas a la degradación enzimática se determinó midiendo la velocidad inicial de solubilización de AGA de acuerdo a los procedimientos empleados para medir la actividad PPasa (Capítulo 2). Como blanco de reacción se emplearon muestras sin enzima. La solubilización en los blancos se tomó como parámetro de la degradabilidad química del sustrato bajo las condiciones de incubación de la reacción enzimática. Previo al ensayo se determinó el perfil pH /actividad sobre M3 y M4 para determinar si el pH óptimo era coincidente con M1. Los resultados indicaron que los perfiles son similares, con un óptimo alrededor de 2.0-2.5 (Figura 4.5).

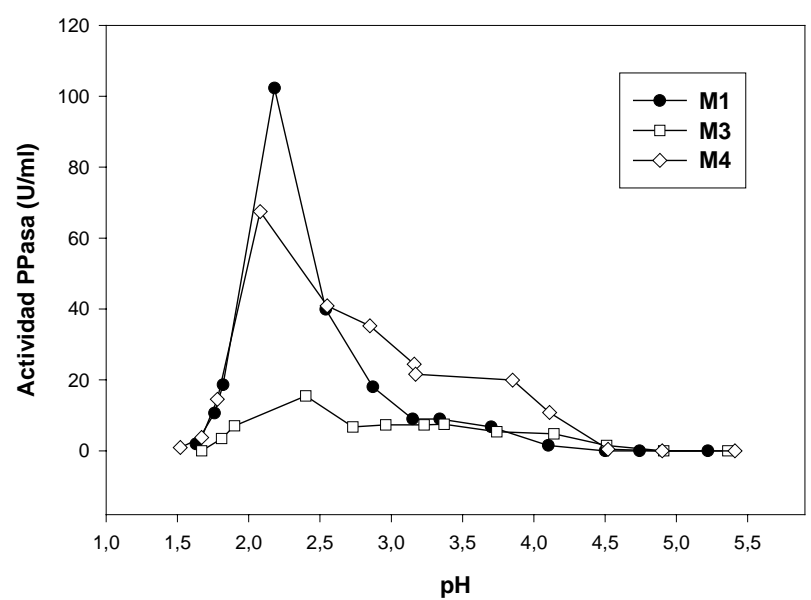

Figura 4.4. Perfil $\mathrm{pH} /$ actividad de $\mathrm{PGI}$ para diferentes protopectinas. Condiciones de reacción: buffer $\mathrm{BCP}, 37^{\circ} \mathrm{C}, 30$ minutos de incubación

En la Tabla 4.5 se presentan los datos de actividad de PGI sobre las diferentes protopectinas y $\mathrm{PL}$ a $\mathrm{pH}$ 2.0. Los resultados de los blancos de reacción fueron consistentes 
con los estudios de estabilidad de las protopectinas a pH 2.0 (Figura 4.4), es decir a menor GM menor solubilización de pectina, observándose claramente la degradabilidad de M5 en condiciones de alta acidez. Para PL, el alto valor del blanco se debe a que este sustrato no fue lavado y aun retiene material soluble que se libera en la incubación, por lo tanto no es válido compararlo con las muestras de protopectina en las medidas de velocidad inicial. La interpretación de los resultados en presencia de enzima no es inmediata, sin embargo para simplificar el análisis podemos asumir que la acción de la enzima y la hidrólisis no enzimática son aditivas. En este sentido, la hidrólisis enzimática parece seguir el mismo patrón de la extracción química. Para las protopectinas de bajo GM (M2 y M3), la solubilización en términos absolutos fue baja, para las muestras de GM intermedia (M1 y M4) la acción enzimática aumentó un $90 \%$ la extracción comparada con el blanco y con M5 si bien el incremento absoluto de pectina extraída fue comparable a M1 y M4, en términos relativos fue muy baja debido a la elevada extracción no enzimática. Las protopectinas de esterificación intermedia parecen ser los sustratos más ventajosos para extraer pectina a $\mathrm{pH} 2.0$ (sin otro aditivo), ya que presentan un balance óptimo entre la cantidad de material solubilizado y la contribución de la enzima al proceso de extracción.

Tabla 4.5. Degradación enzimática de protopectinas por PGI.

\begin{tabular}{cccccc}
\hline & & \multicolumn{2}{c}{ AGA soluble $(\mu \mathrm{g} / \mathrm{ml})$} & \multicolumn{2}{c}{$\begin{array}{c}\text { AGA neto solubilizado en } \\
\text { presencia de PGI }\end{array}$} \\
\hline protopectina & GE (\%) & Blanco & PGI & $\mu \mathrm{g} / \mathbf{m l}$ & \% sobre el blanco \\
\hline M1 & $\mathbf{5 7 . 7}$ & 152 & 288 & 136 & 89 \\
M2 & $\mathbf{1 9 . 6}$ & 34.5 & 59 & 24.6 & 71 \\
M3 & $\mathbf{1 1 . 9}$ & 0.67 & 16 & 15.3 & 2283 \\
M4 & $\mathbf{4 4 . 2}$ & 195 & 375 & 180 & 92 \\
M5 & $\mathbf{7 1 . 0}$ & 1132 & 1291 & 159 & 14 \\
PL* & $\mathbf{5 8 . 0}$ & 700 & 820 & 120 & 17 \\
\hline
\end{tabular}

Condiciones de reacción. $20 \mathrm{mg}$ sustrato $+1 \mathrm{ml}$ de BCP (pH final 2.0-2,2), PGI $\sim 0.01 \mu \mathrm{g} / \mathrm{ml}$ Incubación 30 min a pH 2.0-2.1. * Pomaza de limón empleada como fuente industrial de pectina. Contiene material péctico facilmente extraíble por lavado.

\subsubsection{Extracción de pectina a partir de protopectina con PGI de A. kawachii.}

En el Capítulo 2 se demostró que los dializados del medio glucosa solubilizan sustancias pécticas altamente polimerizadas de cáscara de limón a pH 3.0-3.5. Teniendo en cuenta que la actividad pectinasa ácida de este medio es mayoritariamente llevada a cabo por PGI, se realizó un ensayo para evaluar la extracción de pectina con la enzima pura, empleándose en 
este caso M1. El ensayo de extracción se efectuó a pH 2.0 y $37^{\circ} \mathrm{C}$. El curso del proceso se muestra en la Figura 4.5. En ausencia de enzima, la solubilización de AGA se incrementó lentamente con el tiempo de reacción alcanzando un valor de $0.8 \mathrm{~g} / \mathrm{l}$ luego de $12 \mathrm{~h}$ de incubación, lo que corresponde al $8 \%$ del contenido total de AGA en la protopectina. Aproximadamente el $50 \%$ del AGA soluble resultó polimérico. En presencia de PGI la liberación de AGA se incrementó significativamente observándose una fase inicial rápida (hasta las 6 h) luego de la cual la velocidad de hidrólisis declina. Al cabo de 12-14 h de proceso, el AGA soluble alcanzó una concentración de 3.5-3.8 g/l (50 \% del total) correspondiendo la mayor parte a material polimérico, lo cual confirma que PGI es capaz de solubilizar sustancias pécticas altamente polimerizadas.

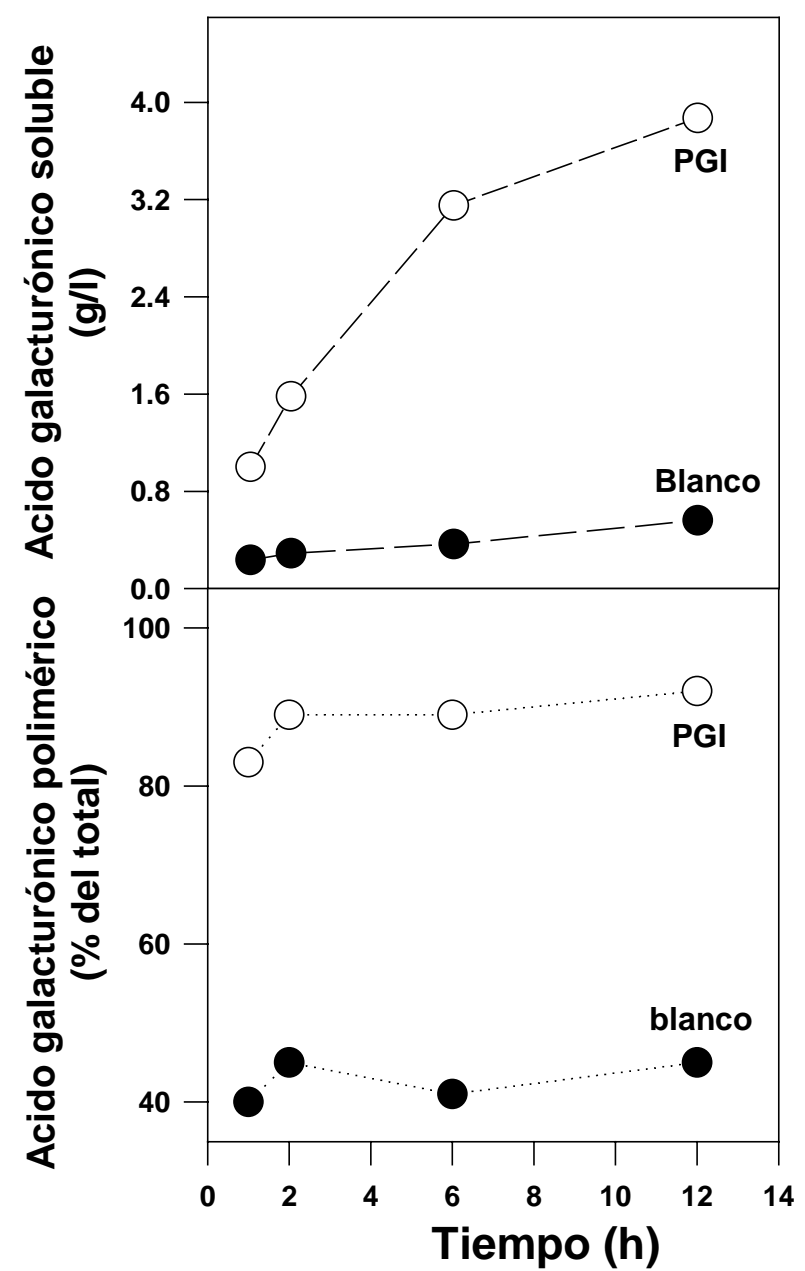

Figura 4.5. Extracción de pectina de protopectina con PGI. 


\subsubsection{Extracción química y enzimática de pectina de pomaza de limón}

Teniendo en cuenta el potencial de PGI para extraer pectina de protopectina se llevó a cabo un proceso de extracción empleando un sustrato comercial como la pomaza de limón. Circunstancialmente, el sustrato industrial presentó un GM de $58 \%$, que resultaría óptimo según los resultados previos con protopectina. Con fines comparativos se efectuó una extracción química y una extracción enzimática con la PGasa de A. niger. Las pectinas extraídas fueron caracterizadas por métodos químicos y cromatográficos. El tratamiento enzimático se efectuó al pH óptimo de cada enzima. Para estimar la concentración de PGI en la mezcla de reacción se utilizó como referencia el proceso de extracción con M1. Se empleó una carga de enzima (E/S, $\mu$ g proteína/g sustrato) 10 veces mayor y el tiempo de reacción se redujo a 2 h. Para la PGasa de A. niger se emplearon tiempos característicos reportados en bibliografía para este tipo de enzima (no necesariamente el óptimo). La concentración de enzima se ajustó para mantener un valor comparable del producto $\mathrm{E} / \mathrm{S} \times$ tiempo de reacción. En la Tabla 4.6 se reportan los datos del proceso de extracción.

Tabla 4.6. Condiciones de extracción y rendimientos de pectinas extraídas enzimática y químicamente de pomaza de limón.

\begin{tabular}{ccccccc}
\hline Método & $\begin{array}{c}\text { E/S } \\
\mu \text { g proteína/g } \\
\text { pomaza }\end{array}$ & $\begin{array}{c}\text { Tiempo } \\
\text { (h) }\end{array}$ & $\mathbf{p H}$ & $\begin{array}{c}\text { Temp } \\
\left({ }^{\circ} \mathbf{C}\right)\end{array}$ & $\begin{array}{c}\text { Rendimiento } \\
\text { de pectina* } \\
(\%)\end{array}$ & $\begin{array}{c}\text { Pomaza } \\
\text { residual** } \\
(\%)\end{array}$ \\
\hline- & 0 & 2 & 2.0 & 37 & 9.6 & - \\
\hline Químico & 0 & 1 & 2.0 & 90 & 20.2 & ND \\
A. kawachii & 11.5 & 2 & 2.0 & 37 & 27.0 & 56.0 \\
- & 0 & 16 & 4.5 & 37 & 2.7 & - \\
A. niger & 1.6 & 12 & 4.5 & 37 & 17.6 & ND \\
\hline
\end{tabular}

Las condiciones de extracción fueron descriptas en Materiales y Métodos (sección 4). E/S relación enzima sustrato $* \mathrm{~g}$ pectina/100 $\mathrm{g}$ de pomaza seca (pectina se refiere al material insoluble en etanol), ${ }^{* *} \mathrm{~g}$ de residuo sólido/100 $\mathrm{g}$ de pomaza seca (calculado luego de la deshidratación con etanol y acetona) N.D.no determinado.

El rendimiento del proceso químico realizado a $90{ }^{\circ} \mathrm{C}$ durante una hora en agua a $\mathrm{pH} 2.0$ (ajustado con $\mathrm{HCl}$ ) fue del $20 \%$, que es un nivel relativamente bajo para pomaza de limón, aunque aceptable industrialmente. Los resultados obtenidos con PGI demuestran que la enzima fue muy eficiente para extraer pectina de PL. El blanco de la reacción enzimática (buffer cítrico a pH 2.0 y $37^{\circ} \mathrm{C}$ ) mostró una solubilización significativa (10\%) evidenciando nuevamente el efecto sinérgico entre la catálisis química y enzimática a $\mathrm{pH}$ 2.0. La 
contribución neta de la enzima al proceso extractivo, asumiendo que son procesos aditivos, fue del $17 \%$. Las pectinas extraídas corresponden al material precipitable con etanol, pero esto no significa homogeneidad química de los productos. Para caracterizar el material extraído, las pectinas se analizaron en relación a la distribución de peso molecular y densidad de carga. Los perfiles de la cromatografía de permeación por gel del extracto químico muestran una fracción de alto peso molecular muy homogénea (pico angosto) y una fracción minoritaria de menor peso molecular constituida fundamentalmente por azúcares neutros (Figura 4.6). Esta fracción minoritaria probablemente corresponda a productos de hidrólisis de cadenas laterales, ricas en azúcares neutros. En el extracto enzimático, la fracción de alto peso molecular es mas polidispersa y se encuentra ligeramente desplazada hacia productos de menor peso molecular. Se observa además una población (pico) minoritaria de mediano peso molecular y la presencia aparente del pico de azúcares neutros, en este caso desplazado hacia la región de menor peso molecular.

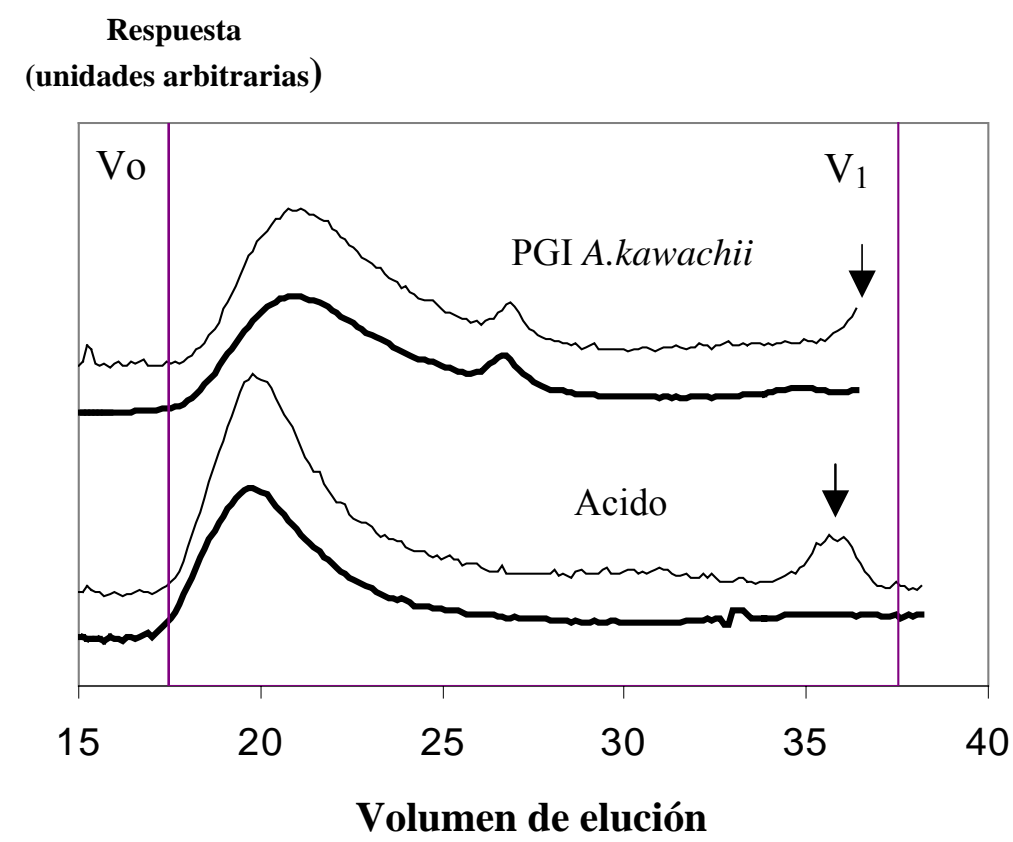

Figura 4.6. Cromatografía de tamiz molecular (HPLC) de extractos químicos y enzimáticos de pomaza de limón. Enzima de A. kawachii (PGI): $11.5 \mu \mathrm{g}$ proteína/g pomaza, 2 h de incubación a $\mathrm{pH}$ 2.0. La línea gruesa corresponde a ácidos urónicos y la línea delgada corresponde a azúcares neutros. $\mathrm{V}_{0}=17.50 \mathrm{~min}$ y $\mathrm{V}_{1}=37.37 \mathrm{~min}$. La flecha indica el pico de azúcares neutros de bajo peso molecular. En el perfil de PGI este pico está interrumpido debido a la finalización de la corrida.

Los perfiles cromatográficos de intercambio aniónico fueron semejantes en ambos extractos (Figura 4.7). Cuando las muestras fueron analizadas por ácido urónico, se observó un pico que eluye con baja fuerza iónica $(\sim 0.2 \mathrm{M})$, es decir corresponde a una pectina con 
baja densidad de carga. De acuerdo a los perfiles de elución reportados para pectinas de manzana con diferente grado de esterificación obtenidos bajo las mismas condiciones de operación de la columna, los picos de la extracción química y enzimática corresponderían a pectinas con grado de esterificación $>50 \%$ [Denés et al., 2000]. La homogeneidad de los picos sugiere además que la población obtenida tiene una distribución aleatoria de grupos carboxilos libres. Cuando las muestras fueron analizadas por orcinol (azúcares neutros) se observó el mismo pico de elución y una pequeña población que no es retenida, correspondiente a material polimérico neutro. Probablemente se trate de la misma fracción neutra que eluye en la cromatografía de tamiz molecular. De ambos cromatogramas surge que las pectinas extraídas químicamente y en presencia de PGI presentan características comunes de metoxilación y difieren ligeramente en el peso molecular del polímero, siendo mas degradado el producto enzimático.

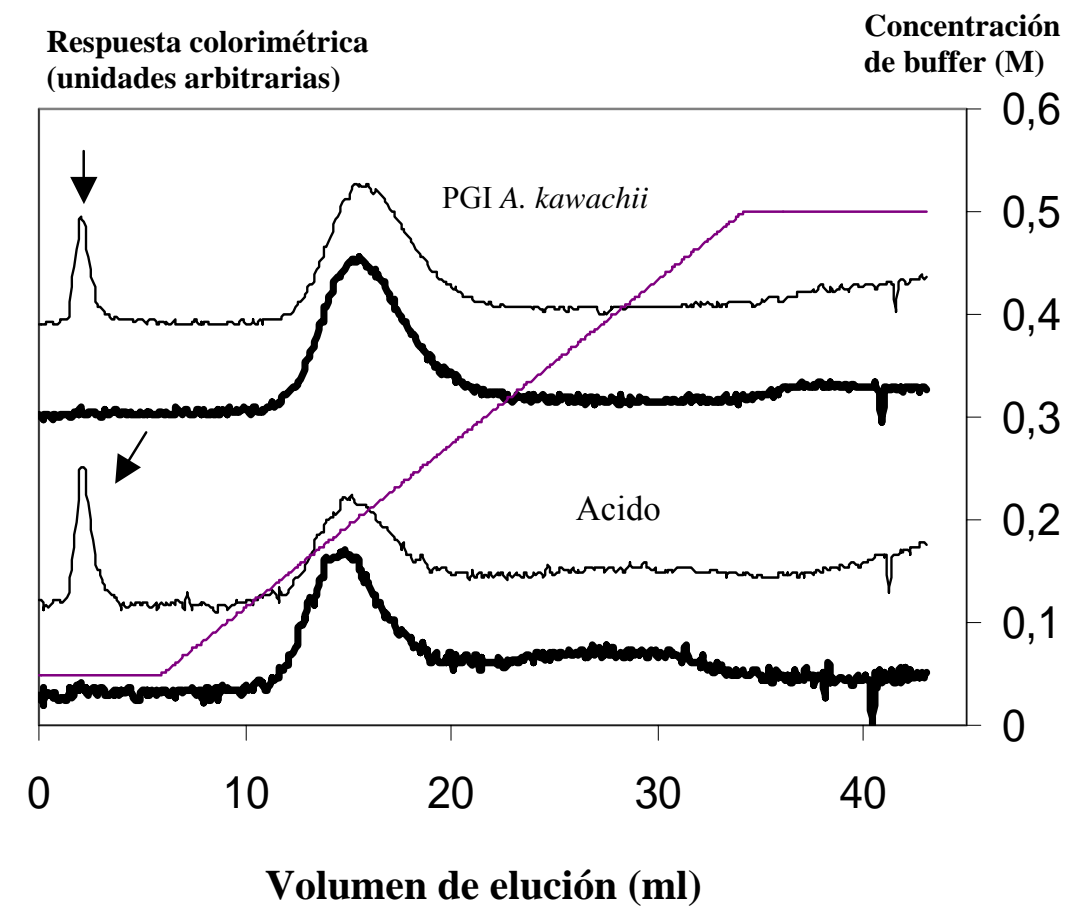

Figura 4.7. Cromatografía de intercambio aniónico (HPLC) de extractos químico y enzimático (PGI) de pomaza de limón. La línea gruesa corresponde a ácidos urónicos y la línea delgada corresponde a azúcares neutros. La flecha indica el pico de azúcares neutros que no se retiene en la columna.

Información complementaria en relación a las propiedades de los materiales descriptos se obtuvo por FTIR (Figura 4.8). La región del FTIR comprendida entre 1800 y $1500 \mathrm{~cm}^{-1}$ es específica de los grupos carboxilos libres y esterificados y permite estimar el valor de GM. Se observa que las áreas relativas de los picos son muy similares en todas las muestras ensayadas 
lo cual confirma la información obtenida por CIAN, es decir que las pectinas son de alto GM (> $50 \%$ ). Otra región de interés es la zona de 1200-800 $\mathrm{cm}^{-1}$ donde absorben los polisacáridos que constituyen la pared celular: celulosa, hemicelulosa y las regiones lisas y pilosas de la pectina. Un detallado estudio del espectro en esa zona fue proporcionado por Kačurácová et al [2000]. En esta región los espectros entre el blanco y el extracto son prácticamente idénticos, en cambio para el extracto químico se observa un cambio relativo en la intensidad de los picos de región entre 1100 y $1050 \mathrm{~cm}^{-1}$. El significado de este cambio no se investigó. En general podemos concluir que los extractos presentan características estructurales y de composición comparables, lo cual sugiere que la reacción de hidrólisis en todos los casos ocurrió por un mecanismo similar. En el caso de las extracciones químicas (blanco de enzima y extracción a $90{ }^{\circ} \mathrm{C}$ ), la misma ocurre simplemente a mayor velocidad bajo condiciones enérgicas de incubación mientras que la presencia de PGI acelera el proceso extractivo en condiciones moderadas de reacción.

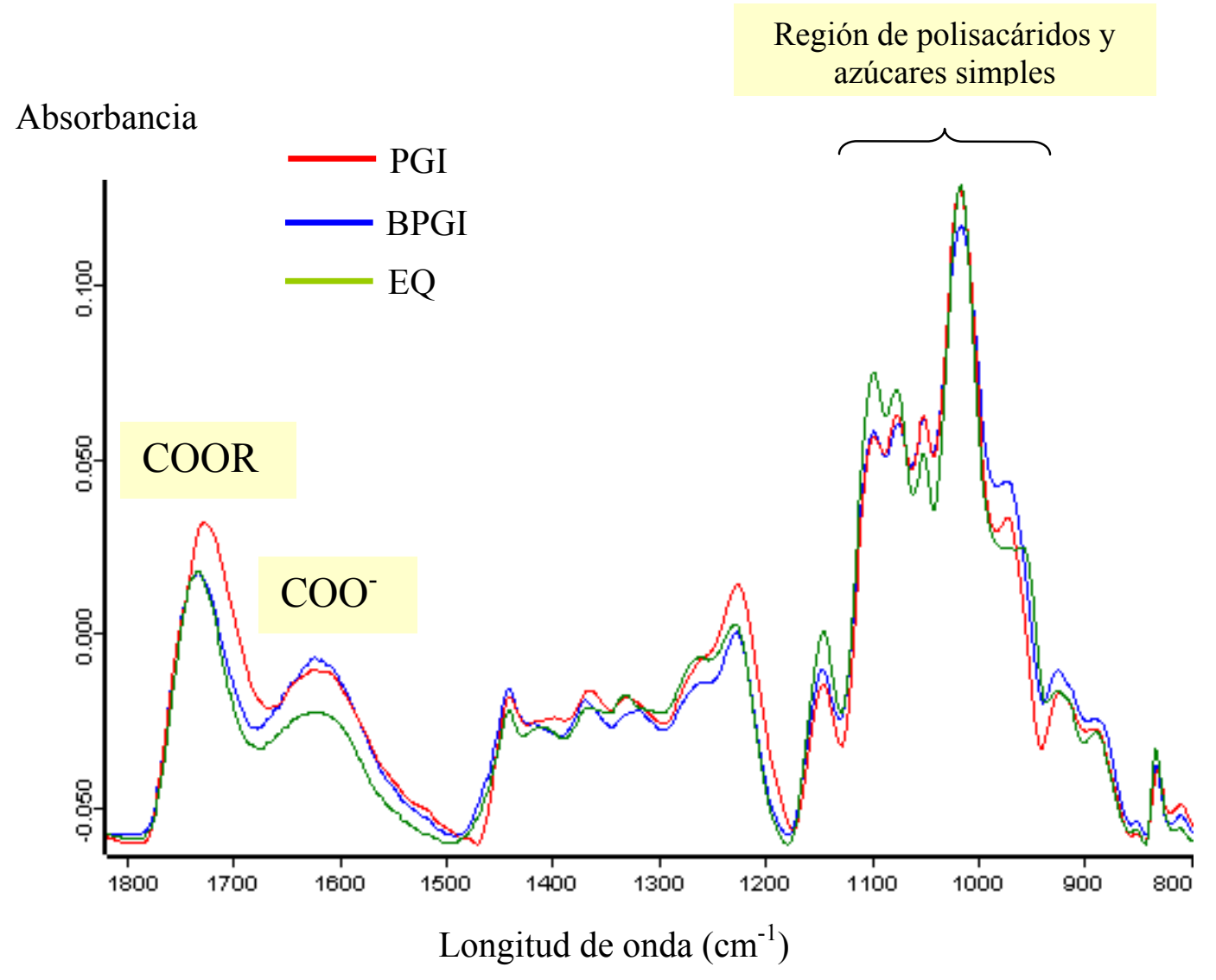

Figura 4.8. FTIR de muestras de pectina extraída químicamente (EQ), en presencia de PGI (PGI) y el blanco de extracción en las condicones de la extracción enzimática (BPGI). La asignación de picos de los carboxilos y regiones del espectro a grupos funcionales se realizó en base a los trabajos de Kamnev et al [1988] y Kačurácová et al [2000]. COOR carboxilo esterificado $\left(1750-1745 \mathrm{~cm}^{-1}\right), \mathrm{COO}^{-}$carboxilo libre $\left(1630 \mathrm{~cm}^{-1}\right)$, región de azúcares neutros $\left(1200-800 \mathrm{~cm}^{-1}\right)$ 
El rendimiento de pectina con la PGasa de A. niger fue $18 \%$ con una contribución neta de la enzima del $15 \%$, es decir de la misma magnitud que la obtenida con PGI. El menor rendimiento total se puede atribuir en parte a una menor contribución de la extracción química, lo cual se ve claramente en el blanco sin enzima (2.7\%). El análisis del extracto por CTM revela que el material extraído se encuentra mas degradado que el extracto químico o el enzimático con PGI (Figura 4.9). Por su parte, los perfiles de elución de la CIAN muestran una población heterogénea que eluye mayoritariamente a altas concentraciones de acetato de amonio (Figura 4.10), es decir presenta mayor densidad de carga, lo cual indica un bajo grado de esterificación de los productos. Esta situación puede ser explicada por la presencia de PME endógena en PL que es activa a $\mathrm{pH} 4.5$ (pero no a $\mathrm{pH}$ 2.0). La acción de esta enzima contribuye además en forma indirecta al menor grado de polimerización de los productos ya que la desesterificación favorece la acción degradativa de la PGasa. Por otra parte, el pico correspondiente a material polimérico neutro es muy pequeño, por lo cual se puede concluir que esta fracción es solubilizada preferentemente a $\mathrm{pH}$ 2.0.

\section{Respuesta colorimétrica}

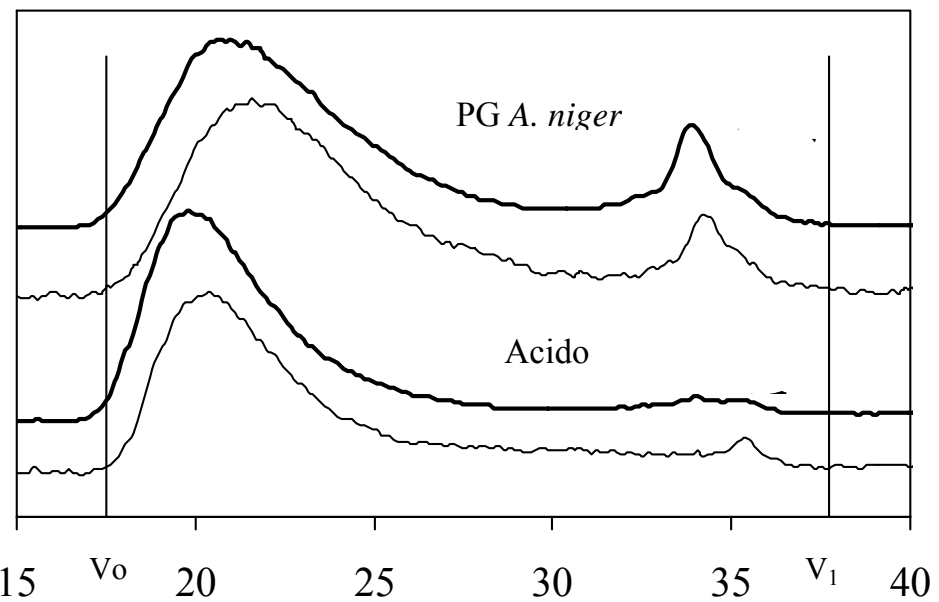

Volumen de elución

Figura 4.9. Cromatografía de tamiz molecular (HPLC) de extractos químico y enzimático de pomaza de limón. Enzima: PGasa de A. niger, $1.6 \mu \mathrm{g}$ proteína/g pomaza, $12 \mathrm{~h}$ de incubación a $\mathrm{pH}$ 4.5. La línea gruesa corresponde a ácidos urónicos y la línea delgada corresponde a azucares neutros. $\mathrm{V}_{0}=17.50 \mathrm{~min}$ y $\mathrm{V}_{1}=37.37 \mathrm{~min}$. 


\section{Respuesta colorimétrica}

\section{Acetato de amonio (M)}

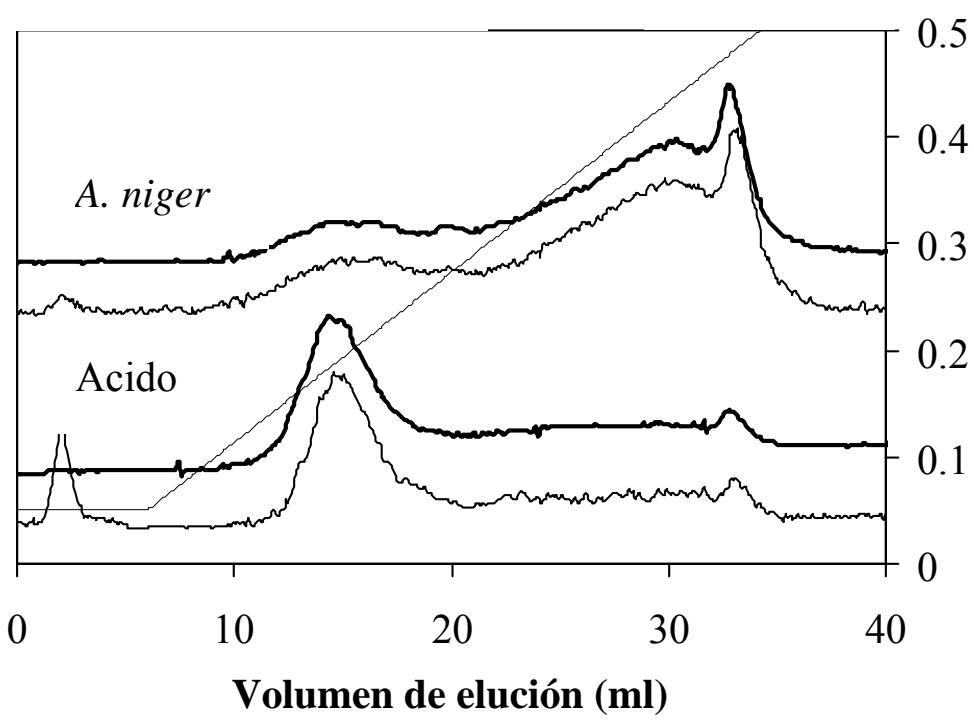

Figura 4.10. Cromatografía de intercambio aniónico (HPLC) de extractos químico y enzimático de pomaza de limón. Enzima: PGasa de A. niger. La línea gruesa corresponde a ácidos urónicos y la línea delgada corresponde a azúcares neutros.

Con el propósito de purificar y caracterizar mejor las fracciones identificadas en la cromatografía analítica, se realizó una cromatografía de intercambio aniónico preparativa. Solamente se efectuaron los análisis del extracto químico y del extracto de $A$. niger, ya que no se dispuso de material extraído con PGI. El perfil de elución del extracto enzimático confirma los resultados de la cromatografía analítica, es decir se observa una población mayoritaria (fracción B) que eluye a alta fuerza iónica característica de productos de bajo GM. En cambio, el extracto químico presenta un pico adicional (fracción C) con las mismas características de elución que el pico B del extracto enzimática (Figura 4.11). Este resultado fue inesperado ya que en la columna analítica este pico no se observó. Los picos característicos del extracto enzimático (comparando con la columna analítica) corresponden en la cromatografía preparativa a la fracción B (alto metoxilo) y a la fracción neutra (A). Las causas que originaron estas diferencias en los cromatogramas del extracto químico no se investigaron. Las fracciones recolectadas fueron combinadas (se indican con una línea), dializadas y liofilizadas para concentrar. El análisis de la composición de carbohidratos expresada en moles \%, se detalla en la Tabla 4.7. Los rendimientos totales calculados en base a la suma de los azúcares individuales fue del 53-60 \%. El bajo porcentaje de glucosa en todas las muestras demuestra que los extractos están constituidos principalmente por sustancias pécticas. La fracción neutra del extracto químico contiene principalmente galactosa (83\%), arabinosa 
(8\%) y cantidades menores de glucosa y manosa. La composición mayoritaria de galactosa sugiere la presencia de una estructura del tipo arabinogalactano tipo II [Ralet and Thibault, 1994]. Este polisacárido se encuentra en las ramificaciones del RG y evidentemente se libera del esqueleto principal por la hidrólisis ácida. Las fracciones ácidas tienen una composición muy semejante, con una relación galacturónico: ramnosa alta (50:1), lo que indica que son ricas en galacturonanos, principalmente $\mathrm{HG}$ y difieren principalmente en el grado de esterificación. El contenido de galacturónico en la suma de las fracciones es del 80 \% que es el valor típico presente en las pectinas industriales obtenidas de residuos cítricos [May, 1990].

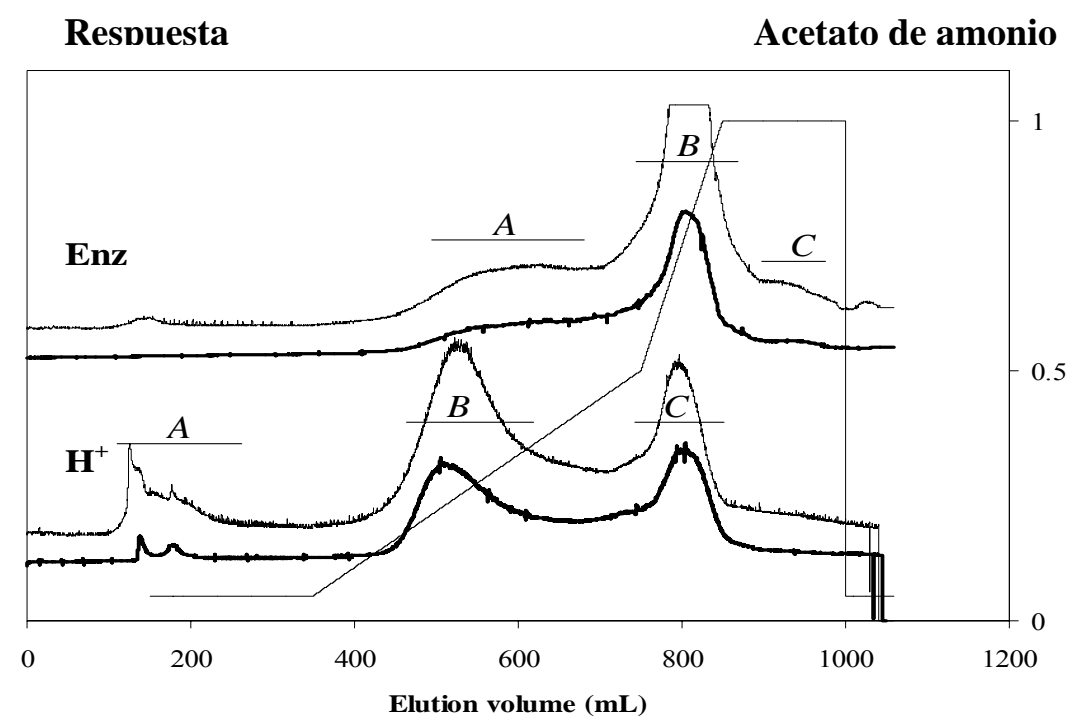

Figura 4.11. Cromatografía de intercambio iónico a nivel preparativo de pectina de extraída enimáticamente y químicamente.

En el extracto enzimático con A. niger se observa una población predominante y dos menores, todas retenidas por la columna. A diferencia del extracto químico, no se observa un pico neutro significativo. El análisis de la composición de las fracciones permite concluir que la acción de la PGasa, en este caso actuando en forma sinérgica con la PME endógena, genera una población mayoritaria de productos que se caracterizan por tener un bajo GM y alto contenido de galacturónico y bajo de galactosa, y por lo tanto es una población rica en HG y una fracción (A) menor mas esterificada y ramificada, a juzgar por su menor densidad de carga y un mayor contenido de azúcares neutros como galactosa y arabinosa. La pequeña 
fracción rica en arabinosa y galactosa que eluye a alta fuerza iónica $(\mathrm{C})$ probablemente se trate de arabinogalactanos asociados a proteínas, lo cual explicaría su adsorción a la columna.

Tabla 4.7. Composición de azúcares de extractos químicos y enzimáticos de pomaza de limón expresados en \% $\mathrm{mol}^{*}$.

\begin{tabular}{|c|cccc|cccc|}
\hline & \multicolumn{4}{|c|}{ Extracción ácida } & \multicolumn{3}{c|}{ Extracción enzimática } \\
\hline Fracción & Total & $A$ & $B$ & $C$ & Total & $A$ & $B$ & $C$ \\
\hline Rendimiento & & 0.04 & 0.49 & 0.23 & & 0.17 & 0.32 & 0.07 \\
Azúcares (\%mol) & & & & & & & & \\
Ramnosa & 1.5 & 0 & 1 & 2 & 1.5 & 0.1 & 0.8 & 6 \\
Fucosa & 0.18 & 0 & 0 & 0 & 0.4 & Tr. & 0 & 0 \\
Arabinosa & 3.5 & 8 & 2 & 3 & 11.8 & 8.7 & 3.6 & 21 \\
Xilosa & 1.7 & 1 & 0.8 & 1 & 2.1 & 0.5 & 0 & 3 \\
Manosa & 0.8 & 4 & 1 & 1 & 1.1 & 0.1 & 0.7 & 14 \\
Galactosa & 12.7 & 83 & 7 & 7 & 8.4 & 5.0 & 2.0 & 33 \\
Glucosa & 1.1 & 3 & 0.5 & 0.5 & 1.1 & 0.5 & 0.4 & 0 \\
Acido urónico & 78 & 0 & 89 & 85 & 74 & 82 & 92.2 & ND \\
\hline
\end{tabular}

*El extracto enzimático se obtuvo con la PGasa de A. niger a pH 4.5. ND no determinado.

\subsubsection{Maceración de tejidos vegetales con concentrados enzimáticos y PGI de A. kawachii.}

Para evaluar las pectinasas de A. kawachii en la maceración de tejidos vegetales se utilizaron primeramente concentrados de los medios con glucosa y pomaza de limón. Como sustrato se usaron cilindros de zanahoria que fueron tratados con calor (escaldado) para inactivar enzimas endógenas y disminuir la carga microbiana. En la Figura 4.12 se muestra el efecto del tipo de concentrado enzimático sobre la capacidad de maceración a pH 2.0 y 5.0.

Bajo condiciones de alta acidez ( $\mathrm{pH}$ 2.0), ambos concentrados fueron capaces de macerar el tejido vegetal. A pH 5.0 la maceración fue menor, en particular con el concentrado Glu. A $\mathrm{pH} 2.0$, la acción macerante en este medio se puede atribuir principalmente a PGI, ya que esta es la pectinasas predominante y la actividad de otras polisacaridasas que degradan pared celular vegetal es muy baja o nula (Capitulo 2). A pH 5.0, la maceración no puede atribuirse a PGI y si a las PGasas moderadamente ácidas. Con el concentrado PL los resultados no pueden explicarse unicamente por la acción de las PGasas ya que en este medio se inducen otras 
pectinasas y polisacaridasas (celulasas, xilanasas, glicosidasas, etc.) que pueden actuar en forma sinérgica con las PGasas, en particular a $\mathrm{pH} 5.0$ donde muestran la mayor actividad (e.j.pectin-liasa, celulasas, etc). En este caso el proceso se semeja mas a una licuefacción que a una maceración. En conclusión A. kawachii produce varias enzimas, entre ellas PGI, que muestran actividad macerante.

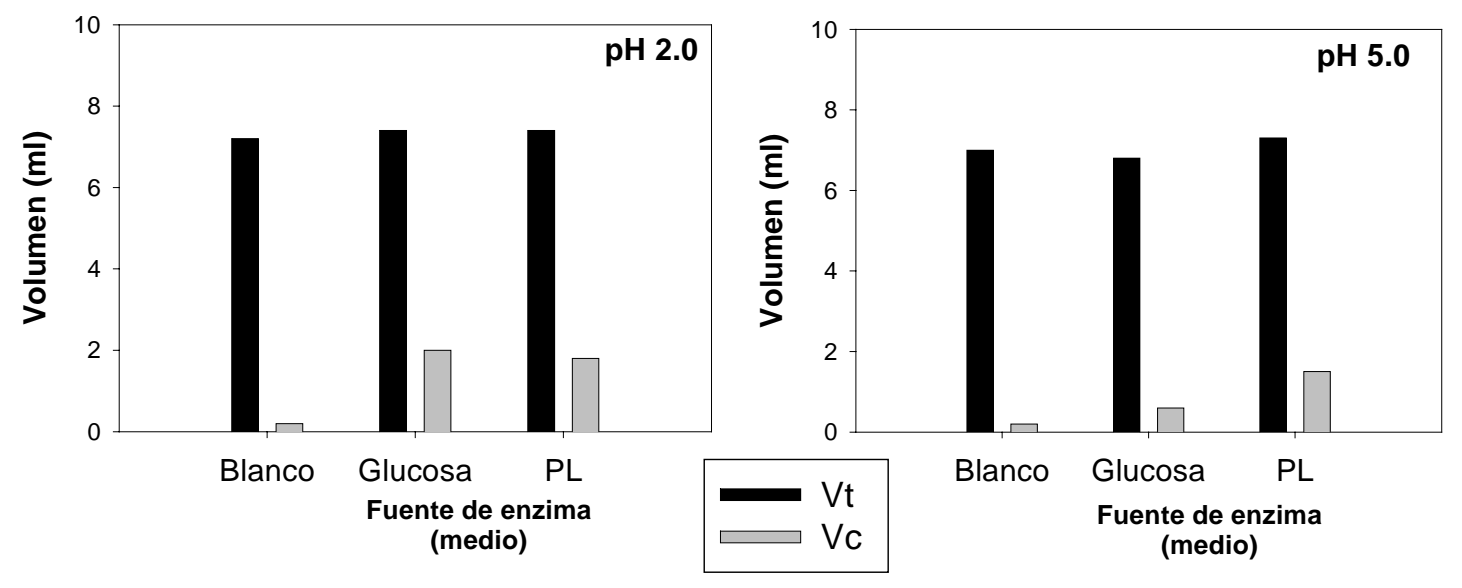

Figura 4.12. Maceración de tejido de zanahoria con concentrados de los medios glucosa y pomaza de limón a pH 2.0 y 5.0. Condiciones de reacción: $2.2 \mathrm{~g}$ de tejido $+7.5 \mathrm{ml}$ cítrico 20 $\mathrm{mM}$ al pH indicado. Incubación: $8 \mathrm{~h}$ a $37^{\circ} \mathrm{C}$. Relación concentrado/sustrato: 1:75 (v/v).

Barras negras: volumen total (Vt); Barras grises: volumen de compactación ( $\mathrm{Vc})$. La actividad macerante se evalúa por Vc.
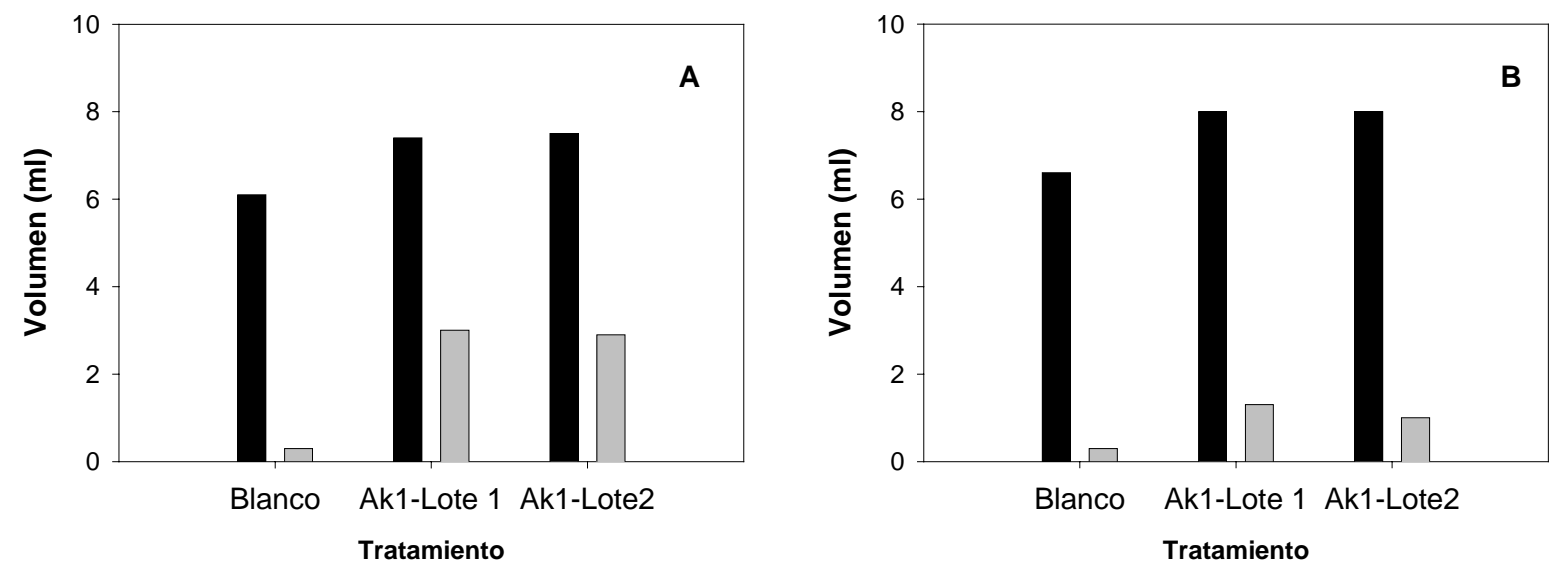

Figura 4.13. Maceración de tejido de zanahoria (A) y pimiento (B) por PGI Condiciones de reacción: $2.2 \mathrm{~g}$ de tejido $+7.5 \mathrm{ml}$ cítrico $20 \mathrm{mM}, \mathrm{pH}$ 2.0-2.2 (mezcla final) Incubación: $8 \mathrm{~h}$ a $37^{\circ} \mathrm{C}$, PGI $2.6 \mu \mathrm{g} / \mathrm{g}$ de sustrato

Barras negras: volumen total (Vt); Barras grises: volumen de compactación (Vc). La actividad macerante se evalúa por Vc. 
Luego del ensayo con los concentrados del medio, se evaluó la capacidad macerante de la enzima pura sobre tejidos de zanahoria y pimiento a $\mathrm{pH}$ 2.0. En ambos casos la maceración fue positiva aunque se observaron importantes diferencias en los valores de Vc (Figura 4.13). En la Figura 4.14 se muestra una micro- y macro-fotografía del macerado de zanahoria. Se puede observar claramente que la enzima disgrega el tejido pero no desintegra las células. La PGasa es una enzima especifica de las sustancias pécticas y no degrada celulosa, por lo cual las células no se lisan.

La maceración también se evaluó sobre tejidos vegetales suaves tales como frutilla (Figura 4.15). En este caso se observó liberación de antocianinas al medio extracelular, probablemente debido a la permeabilización de las células, ya que no se observó lisis. El color del macerado mantuvo su característica inicial debido al bajo pH de la reacción.
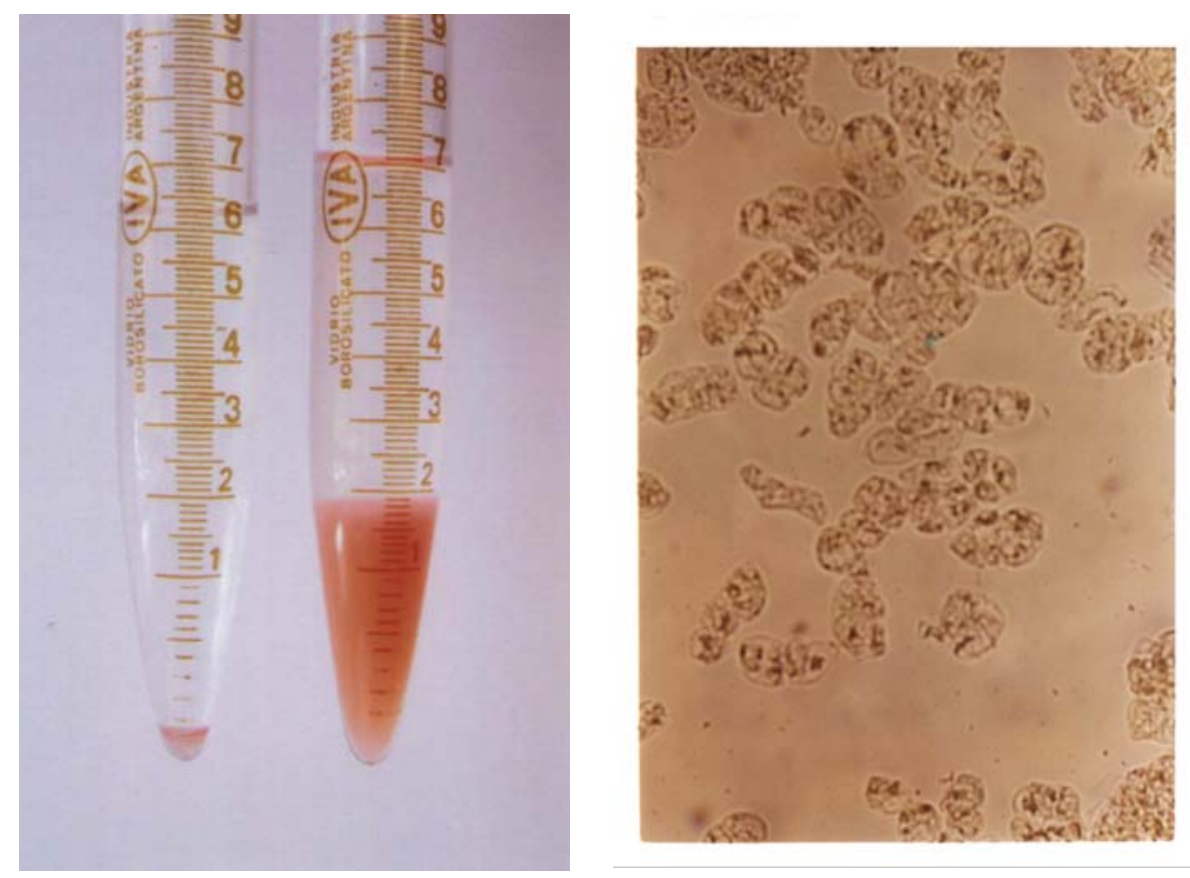

Figura 4.14. A: Fotografía de macerado de cilindros escaldados por PGI (derecha) y control ( $\sin$ enzima). Las condiciones de maceración son detalladas en la Figura 4.13. B: Microfotografía de macerado de zanahoria con PGI de A. kawachii $(10 \times)$. 


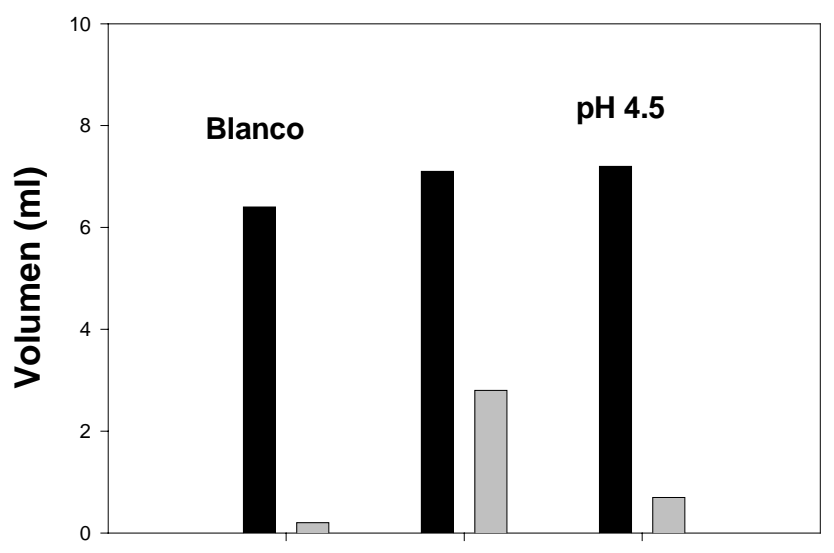

Figura 4.15. Maceración de frutilla con PGI.

Condiciones de reacción: $2.2 \mathrm{~g}$ de tejido $+7.5 \mathrm{ml}$ cítrico $20 \mathrm{mM}, \mathrm{pH} 2.0$ (mezcla final) Incubación: 2 h a $37^{\circ} \mathrm{C}$ a pH 2.0 o 4.5, PGI $2.6 \mu \mathrm{g} / \mathrm{g}$ de sustrato

Barras negras: volumen total (Vt); Barras grises: volumen de compactación (Vc). La actividad macerante se evalúa por Vc.

\subsection{Discusión}

Los resultados del presente estudio demuestran que PGI fue muy efectiva para degradar sustratos insolubles en condiciones de alta acidez. A diferencia de la hidrólisis de la celulosa, muy poco se ha estudiado sobre las reacciones heterogéneas catalizadas por las pectinasas. La extracción enzimática de pectina y la maceración de tejidos vegetales son reacciones sobre sustratos insolubles y por lo tanto es de esperar que la macro y microestructura del sustrato condicionen su degradabilidad y determinen los rendimientos y propiedades del producto final. Sin embargo, hay que considerar que el sistema es mas complejo que la celulosa, debido a la coexistencia de varios tipos de polisacáridos (incluyendo la celulosa) y a la gran complejidad química de la pectina presente en estos materiales. En este sentido las protopectinas pueden constituir un sustrato modelo para los estudios con enzimas que degradan pared celular vegetal.

Para la obtención de protopectinas de limón se utilizaron diferentes procedimientos dando lugar a materiales de composición química similar en cuanto al contenido de azúcares y ácido galacturónico pero con diferente GM. La composición de las protopectinas está en concordancia con datos reportados en literatura para los denominados materiales insolubles en 
etanol obtenidos de limón [Ros et al., 1997]. Las diferencias en GM son atribuibles a la acción de la PME endógena que evidentemente se activa durante el tratamiento. El control del proceso de obtención de la protopectina en relación a la actividad PME resulta por lo tanto fundamental para obtener un material con GM definido.

El análisis de las isotermas de adsorción de agua nos indica que las protopectinas tienen características estructurales muy parecidas con presencia de microporos $(<20 \AA)$ y mesoporos (20-500 ̊̊). Los valores de $\mathrm{S}_{\text {esp }}$, calculados a partir del valor de saturación de los mesoporos (segundo escalón), resultaron extremadamente altos $\left(600-700 \mathrm{~m}^{2} / \mathrm{g}\right)$ en comparación con los obtenidos por porosimetría de nitrógeno; 1.2-1.3 $\mathrm{m}^{2} / \mathrm{g}$ para las muestras M1 y M3. Independientemente de las discrepancias, es evidente que ambos métodos dan el mismo valor relativo de $\mathrm{S}_{\text {esp. }}$. Existen al respecto pocos datos de distribución de tamaño de poros y $\mathrm{S}_{\text {esp }}$ para materiales constituidos por pared celular vegetal. Algunos estudios realizados mediante porosimetría de nitrógeno o $\mathrm{Hg}$ con cáscaras de naranja y manzana sugieren que las dimensiones de los poros en estos materiales varia ampliamente, en varios ordenes de magnitud, no habiendo una distribución sistemática de los mismos. El menor tamaño de poro estimado fue de $23 \AA$ y los valores de $\mathrm{S}_{\text {esp }}$ entre $6.9-25 \mathrm{~m}^{2} / \mathrm{g}$ [Panchev and Karageorgiev, 2000]. Otros datos de $S_{\text {esp }}$ reportados para fibras comerciales de manzana y cítrico dan valores de 0.2 a $0.5 \mathrm{~m}^{2} / \mathrm{g}$ [Thibault and Ralet, 2000]. Estas variaciones demuestran la necesidad de investigar sobre los métodos de análisis de porosidad de materiales hidrofílicos con grupos ionizables, a fin de obtener información mas precisa acerca de su microestructura.

Las características de porosidad que resultan del análisis de las isotermas no encontró correlación con $\mathrm{CH}$. Estas diferencias podrían atribuirse al hecho que $\mathrm{CH}$ indica la capacidad de expandirse del material por absorción de agua en condiciones de exceso de líquido, mientras que las isotermas son condiciones de equilibrio con vapor de agua. Es importante destacar al respecto que $\mathrm{CH}$ se determinó en buffer cítrico a pH 2.0, en cambio el pH de las muestras no fue controlado durante la determinación de las isotermas de adsorción de agua. De que manera este parámetro puede influir en las características de las isotermas, es algo que debe investigarse. Teniendo en cuenta que las pectinas son las principales responsables de la absorción de agua en las paredes celulares vegetales [Thibault and Ralet, 2000], se buscó establecer alguna relación entre $\mathrm{CH}$ y la composición química de las protopectinas, encontrándose una correlación positiva entre $\mathrm{CH}$ y $\mathrm{GM}$; es decir a $>\mathrm{GM}>\mathrm{CH}$. Los valores de $\mathrm{CH}$ para las protopectinas mas esterificadas son del mismo orden que las reportadas para pomaza de manzana y cáscara de cítricos, $\sim 7-10 \mathrm{ml} / \mathrm{g}$ [Thibault and Ralet, 2001]. 
Las protopectinas liberan sustancias pécticas como consecuencia de reacciones de hidrólisis o de beta eliminación. Estas reacciones pueden ser catalizadas química o enzimáticamente. Por ser un sistema heterogéneo, la hidrólisis es afectada no solo por las características químicas del sustrato sino también por su estructura micro y macroporosa. La diferente actividad PGI sobre las protopectinas, medida como velocidad inicial, no pueden ser explicadas por fenómenos de superficie o porosidad que limitan en mayor o menor grado la acción de la enzima sobre la partícula, ya que en términos generales los materiales exhibieron una estructura física similar. Las diferencias, en cambio parecen estar asociadas a la estructura química intrínseca, en particular GM. Sin embargo, la mayor actividad PGI se observó con las protopectinas de mayor GM (entre 40 y $70 \%$ ), lo cual fue inesperado ya que era de suponer que la enzima hidrolizara mas rápidamente los sustratos menos esterificados (como ocurre con los sustratos solubles). Los resultados de la extracción no enzimática, en la cual las posibles limitaciones estructurales que impone el sustrato se minimizan aún mas, muestran en parte un patrón similar al enzimático y sugieren alguna explicación para los resultados obtenidos. La extracción de pectina de M3 (menos esterificada) dependió marcadamente del pH y de la presencia de agentes quelantes. A pH 5.0 la pectina fue solubilizada únicamente en presencia de HMNa. De acuerdo al modelo de estructura de la pared celular (Figura 1.4), la no extractabilidad de pectina de M3 puede ser explicada por la formación de complejos insolubles que resultan de la interacción de los grupos carboxílicos del HG con calcio u otro catión divalente. El HMNa por su capacidad de secuestrar el calcio, previene la formación del gel y permite liberar la pectina soluble de bajo metoxilo que se produjo durante la hidrólisis del material. Esta situación no ocurrió con M5. En este caso la formación de los complejos con calcio se ve impedida por la alta esterificación y la pectina es fácilmente extraíble sin agente quelante. A pH 2.0 la situación fue diferente. Con M3 el efecto del HMNa no se observó y la solubilización fue mucho menor que la obtenida a pH 5.0 con HMNa. Mas aún, el resultado fue inverso respecto al que se obtuvo con M5 en cuyo caso la solubilización a pH 2.0 se incrementó respecto de $\mathrm{pH}$ 5.0, lo cual es consistente con un incremento de la "catálisis ácida" a menor pH [May, 1990]. La ausencia de un efecto "gel" a pH 2.0 es atribuible a la protonación del AGA que impide la formación del complejo con el calcio (el pK del APG se ha estimado en 3.4 [Rudan-Tasič and Klofutar, 1996]. En este sentido el rango de pH reportado para que ocurra gelificación es 2.5-6.0 [Thibault and Ralet, 2001]. La baja solubilización de pectina de los sustratos con bajo GM podría explicarse por la disminución de solubilidad que las sustancias pécticas desesterificadas exhiben con la disminución del pH, 
lo cual conduce a su precipitación (Capítulo 3). Esto podría ocurrir dentro de la matriz impidiendo la difusión del polímero péctico hacia la fase soluble.

En base a la discusión anterior podemos inferir que la "baja actividad" enzimática sobre las protopectinas de bajo GM, es probablemente un efecto de solubilidad de las sustancias pécticas dentro de la matriz que impide la liberación de los productos de hidrólisis y/o bien restringe la hidrolisis enzimática al modificar la condición física del sustrato. Es interesante destacar que existe muy poca información bibliográfica sobre este tipo de estudios. No obstante, Voragen et al [1980] observaron que la efectividad de una endo-PGasa de levadura fue mayor sobre los materiales insolubles en agua con bajo GM (9 \%) comparada con la degradación de materiales insolubles en solventes de alto GM (75 \%).

Es importante destacar el hecho que la reacción enzimática sobre la protopectina ocurre inicialmente por un ataque superficicial de la partícula [Cavallito et al, 1997] y es la situación mas probable en las medidas de velocidad inicial. La micro y macroporosidad de las partículas determinarán si la PGasa es luego capaz de penetrar al entramado y degradar el resto de polisacárido. Es evidente que esto ocurre en el caso de la protopectina M1 y PL ya que la solubilización de pectina fue alta en ambos casos.

Los experimentos de extracción de pectina de PL con PGI a pH 2.0 mostraron que esta PGasa solubiliza pectina con características semejantes a la obtenida mediante extracción química. Es de hacer notar que la hidrólisis no enzimática coexiste con la enzimática y es difícil establecer la contribución de cada una de ellas al rendimiento final. Sin embargo, tanto la extracción de pectina de M1 como de PL mostraron que a pH 2.0 la liberación no enzimática en las condiciones bajo las cuales se efectúa la reacción enzimática, es relativamente lenta, y por lo tanto el aporte de la enzima al rendimiento total es muy significativo. Los rendimientos obtenidos con PGI son del orden de los reportados para pectinas extraídas de limón por métodos químicos, enzimáticos o físicos; rango 18-44\% [Donaghy y McKay, 1994; Ralet y col., 1994; Rodríguez-Jasso et al., 2002]. Los métodos enzimáticos corresponden a extracciones realizadas con PGasas, RG-hidrolasas o extractos crudos en condiciones muy variadas de $\mathrm{pH}(2.0-5.0)$, temperatura $\left(25-50{ }^{\circ} \mathrm{C}\right)$ y tiempos de reacción (2-24 h). Los únicos reportes a $\mathrm{pH} 2.0$ fueron para las PGasas de un mutante de $A$. niger C [Leuchtenberger et al., 1992] y para la PPasa-AS de A. awamori [Nagai et al 2000]. Como se mencionó en el Capítulo anterior, la PPasa-AS y PGI son enzimas con propiedades muy semejantes. El rendimiento reportado por Nagai et al [2000] fue del $29 \%$ luego de incubar $16 \mathrm{~h}$ a $37^{\circ} \mathrm{C}$. La pectina extraída no fue caracterizada y no se reporta si efectivamente 
es material polimérico, tampoco se reporta la contribución neta de la enzima ya que no hay valores para los blancos sin enzima.

Los perfiles de las cromatografías de permeación por gel e intercambio iónico indican que los extractos están constituidos principalmente por poblaciones de alto peso molecular y alto grado de esterificación con una distribución aleatoria de grupos metoxilo. La pectina extraída químicamente resultó mas homogénea en relación a la distribución de peso molecular. Estas características de las pectinas son concordantes con datos reportados previamente para pectina extraídas de limón a escala de laboratorio [Ros et al., 1996] e industrial [Kravtchenko, 1992]. El análisis de la composición química de la pectina extraída químicamente, indica la predominancia de galacturonanos, en particular $\mathrm{HG}$, y una pequeña población neutra probablemente derivada de la hidrólisis de las cadenas laterales presentes en la región pilosa. Es probable que la pectina extraída en presencia de PGI tenga una composición similar.

Un aspecto interesante a resaltar de estos estudios es la presencia de PME en el sustrato para extraer pectina. En la práctica industrial el control de la actividad PME es fundamental en las etapas previas al secado del material, ya que la desesterificación del sustrato daría lugar a pectinas sensibles al calcio o de baja metoxilación. Sorpresivamente la pomaza de limón industrial mostró una actividad residual de PME. Durante la extracción química, la PME se inactiva por las condiciones del tratamiento y por lo tanto su efecto sobre la pectina sería nulo, en cambio en la extracción enzimática su actividad puede alterar el producto según el $\mathrm{pH}$ de la reacción Esto se hace evidente al comparar la extracción enzimática con PGI y la PGasa de $A$. niger. A pH 2.0 la PME endógena es inactiva pero a $\mathrm{pH} 4.5$ desesterifica mediante un mecanismo aleatorio [Vries et al, ]. Esto explicaría porque la pectina obtenida con PGI tiene un GM comparable a la pectina obtenida por extracción química, mientras que la pectina extraída con la PGasa de A. niger presentó un bajo GM.

Otra aplicación evaluada con PGI fue la maceración bajo condiciones muy ácidas. La mayoría de las endo-PGasas tienen la capacidad de macerar tejidos vegetales y su aplicación no solo se limita en la industria de los alimentos, sino también a otras aplicaciones industriales [Voragen et al., 2001]. La posible ventaja de macerar a pH 2.0 reside en un mayor control de la contaminación, la preservación de las características organolépticas y la posibilidad obvia de procesar frutas con alta acidez e.j. tamarindo. PGI fue capaz de macerar zanahoria, pimiento rojo y frutilla a $\mathrm{pH}$ 2.0. Este comportamiento demuestra la alta efectividad de la enzima para hidrolizar las pectinas de la pared celular vegetal en condiciones de alta acidez . 


\subsection{Bibliografía}

Baquero, C. and Bermudez, A.S. (1998). In: Temas en Tecnología de Alimentos. F.M. Lajolo and E. Wenzel de Menses (Eds.). Vol. 2. Fibra dietética. Programa Iberomaericano de Ciencia y Tecnología para el Desarrollo (CYTED)-Instituto Politecnico Nacional (IPN), México. pp:207-214.

Blumenkrantz, N. and Asboe-Hansen, G. A. (1973). Method for quantitative determination of uronic acids. Analytical Biochemistry, 54:484-489.

Cavalitto, S.F.; Hours, R.A. and Mignone, C.F. (1997). Quantification of pectin-releasing activity of protopectinase-SE from Geotrichum klebahnii. Biotechnology Techniques, $11: 331-334$.

Choi, J.S.; Cho, Y.J. (2000). Characteristics of apple pectins extracted with different extraction methods. Food Engineering Progress, 4:70-75.

Contreras-Esquivel, J.C.; Hours, R.A.; Aguilar, C.N.; Reyes-Vega, M.L. Romero, J. (1997). Revisión: extracción microbiológica y enzimática de pectina. Archivos Latinoamericanos de Nutrición, 47:208-216.

Donaghy, J.A.; McKay, A.M. (1994). Pectin extraction from citrus peel by polygalacturonase produced on whey. Bioresource Technology, 47:25-28.

De Vries, J (1988). Repeating units in the structure of pectin. In: Gums Stab. Food Ind. 4, [Proc. Int. Conf.], 4th. Phillips, Glyn Owain; Williams, Peter Anthony; Wedlock, David J. (Eds.). IRL, Oxford, UK. pp:25-29.

Denès, J.-M.; Baron, A.; Renard, C.M.G.C.; Péan, C.; Drilleau, J.-F. (2000). Different action patterns for apple pectin methylesterase at $\mathrm{pH} 7.0$ and 4.5. Carbohydrate Research, 327:385-393.

Dongowski, G. and Lorenz, A. (1998). Unsatured oligogalacturonic acids are generated by in vitro treatment of pectin with human faecal flora. Carbohydrate Research, 314:237-244.

Fu M. Zhang, Z. Z. and Low, P. F. (1990). Changes in the properties of a montmorillonitewater system during the adsorption and desorption of water: hysteresis. Clay and Clay Minerals, 38:485-492.

Hagymassy, J.Jr.; Brunauer, S. and Mikhail, R.S. (1969). Pore structure analysis by water vapor adsorption. I. t-curves for water vapor. Journal of Colloid and Interface Science, 29:485-491.

Hwang, J.-K. (2001). Production of functional carbohydrates by the extrusion reactor. Food Science and Biotechnology, 10:455-459. 
Kačurácová, M.; Capek, P.; Sasinková, V.; Wellner, N. and Ebringenová, A. (2000). FT-IR study of plant cell wall model compounds: pectic polysaccharides and hemicelluloses. Carbohydrate Polymers, 43:195-203.

Kamnev, A.A.; Colina, M.; Rodríguez, J.; Ptitchkina, N.M. and Ignatov, V.V. (1998). Comparative spectroscopic characterization of different pectins and their sources. Food Hydrocolloids, 12:263-271.

Kravtchencko, T.P. (1992). Studies on the structure of industrial high methoxyl pectins. PhD thesis. Wageningen Agricultural University, The Netherlands. pp:1-173.

Leuchtenberger, A.; Krause, M.; Junghans, H.; Mayer, G.; Welzel, J. (1992). Isolation of A. niger mutants with protopectinase activity at very low $\mathrm{pH}$. BioEngineering, 4:36-43.

May, C.D. (1990). Industrial pectins: sources production and applications. Carbohydrate Polymers, 12:79-99.

Matora, A.V.; Korshunova, V.E.; Shkodina, O.G.; Zhemerichkin, D.A.; Ptitchkina, N.M.; Morris, E.R. (1995). The application of bacterial enzymes for extraction of pectin from pumpkin and sugar beet. Food Hydrocolloids, 9:43-46.

\section{Mansfield}

Massiot, P and Renard, C.M.G.C. (1997). Composition, physico-chemical properties and enzymatic degrdation of fibres prepared from different tissues of apple. Food Science and Technology, 30:800-806.

Nagai M, Ozawa A, Katsuragi T, Sakai T. (2000). Purification and chracterization of acidstable protopctinase produced by Aspergillus awamori in solid-state fermentation. Biosci Biotechnol Biochem; 64:1337-1344.

Pruthi, J. S. (1965) Isolation, characterization, and recovery of pectin from passion fruit waste (rind). Chem. Ind. (London) 13:555-559.

Panchev, I.; Karageorgiev, S. (2000). Investigation of some physical characteristics of plant structures which are used as sources of pectic substances. International Journal Food of Foods Science and Technology, 35:341-350.

Renard, C. (1989). Etude des polysaccharides parietaux de la pomme. Extraction at caracterization par des methodes chimiques et enzymatiques. These de Doctorat, Université de Nantes, France.

Ralet, M.-C.; Thibault, J.-F. (1994). Extraction and characterization of very high methylated pectis from lemon cell walls. Carbohydrate Research, 26:283-296.

Rodriguez, Jasso, R.M. (2003). Desarrollo de una metodología alternativa para la extracción de pectina de cáscara de limón mexicano mediante un tratamiento termoquímico. Tesis de 
Licenciatura (Ingeniería Química). Departamento de Investigación en Alimentos. Facultad de Ciencias Químicas. Universidad Autónoma de Coahuila, Saltillo, Coahuila, México.

Ros, J.M.; Schols, H.A.; Voragen, A.G.J. (1996). Extraction, characterization, and enzymic degradation of lemon peel pectins. Carbohydrate Research, 282:271-284.

Royo-Iranzo, J.; Miralles, M.C.; Claramunt, P. (1975). Preparación de corteza de naranja para la obtención de pectina a partir de dos variedades cultivadas en España. Rendimiento y calidad del producto. Agroquímica Tecnología de Alimentos, 15:539-546.

Rudan-Tasič, D. and Klofutar, C. (1996). Potentiometric titration of poly( $\alpha-D)$ galacturónico acid. In: Pectins and Pectinases. J. Visser and A.G.J. Voragen (Eds.). Elsevier Science B.V.: The Netherlands. pp:609-617.

Sakai T, Sakamoto T, Hallert J, Vandamme E.J (1993). Pectin, pectinase, and protopectinase: production, properties, and applications. Adv. Appl. Microbiol. 39:213-294.

Sakamoto, M.; Shirane, Y.; Naribayashi, I.; Kimura, K.; Morishita, N.; Sakamoto, T; Sakai, T. (1994). Purification and characterization of rhamnogalacturonase with protopectinase activity from Trametes sanguinea. European Journal of Biochemistry, 226:285-291.

Thibault, J.F. (1979). Automatisation du dosage des substances pectiques par la méthode au méta-hidroxydiphényl. Lebensm.-Wiss.u.-Technnol., 12:247-251.

Thibault, J.K. and Ralet, M.C. (2001). Pectins, their origin, structure and functions. In: Advanced Dietary Fibre Technology. B.V. McCleary and L. Prosky (Eds). Blackwell Science: United Kindom. pp:369-378.

Tollier, M.T.; Robin, J.P. (1979). Adaptation de la métode à l'orcinol sulfurique au dosage automatique des oses neutres et totaus. Ann Technol Agric.,. 28:1-15.

Turakhozhaev, MT. And Khodzhaev, M.A. (1993). Plant pectin substances. Methods of isolating pectin substances. Chemistry of Natural Compounds, 31:457-459.

Versteeg, C. (1979). Pectinesterases from the orange fruit : their purification, general characteristics and juice cloud destabilizing properties. $\mathrm{PhD}$ thesis. Wageningen Agricultural University, The Netherlands.

Voragen, A.G.J.; Heutink, R.; Pilnik, W. (1980). Solubilization of apple cell walls with polysaccharide-degrading enzymes. Journal of Applied Biochemistry, 2:452-468.

Voragen, F.; Beldman, G.; Schols, H. (2001). Chemistry and enzymology of pectins. In: Advanced Dietary Fibre Technology. B.V. McCleary and L. Prosky (Eds). Blackwell Science: United Kindom. pp:379-398. 
Wood, P.J. and Siddiqui, I.R. (1971). Determination of methanol and its application to measurement of pectin ester content and pectin methyl esterase activity. Analytical Biochemistry, 39:418-428. 


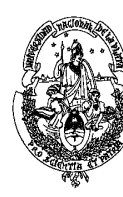

UNLP

\section{$\mathbf{C}^{\text {aprTuLO }} 5$}

Tesis Doctoral

Argentina

\section{Adsorción de poligalacturonasas de Aspergillus kawachii a filtros de fibra de vidrio}

Resumen

Las PGasas activas a pH 5.0 que produce A. kawachii en el medio glucosa/triptona, fueron selectivamente adsorbidas a filtros de fibra de vidrio (FFV) de borosilicato. El proceso de adsorción (y elución) dependió fuertemente del $\mathrm{pH}$ y fuerza iónica del medio pero no fue afectado por detergentes. Esta característica sugiere que la interacción principal de las PGasas con el vidrio borosilicato es de naturaleza electrostática y/o involucra puentes de hidrógeno. La adsorción presenta además cierta bioespecificidad, ya que PGI no se adsorbió a FFV pero si lo hicieron otras PGasas, como las A. niger y Geotrichum klebanii, que tienen en común la propiedad de ser activas a $\mathrm{pH} 5.0$ pero inactivas a $\mathrm{pH}$ 2.0. El factor de purificación de la actividad PGasa luego del proceso de adsorción al filtro y posterior elución fue $\sim 100$, siendo en este sentido la operación comparable con otros procesos de purificación de alta resolución, como la cromatografía de fase reversa, de afinidad o bioespecífica. Las proteínas adsorbidas fueron purificadas por cromatografía de intercambio catiónico (CIC) y finalmente por tamiz molecular. La CIC permitió separar dos fracciones con actividad PGasa, una mayoritaria (> 95 \% de la actividad total, PGII) y una minoritaria (PG III). El análisis por SDS-PAGE del eluído del FFV y la cromatografía de intercambio catiónico mostró que las PGasas son prácticamente las únicas proteínas presentes luego del proceso de filtración (adsorción y elución). Desde el punto de vista de la purificación de proteínas, la filtración por FFV puede considerarse como un proceso integrativo, es decir permite separar fases (sólido/líquido), purificar y concentrar. Como sistema cromatográfico es análogo a la cromatografía de membrana que posee varias ventajas respecto del uso de columnas como son: mayor caudal de operación debido a menores restricciones difusionales y resistencia al flujo, mayor facilidad de cambio de escala y menor costo operativo.

\subsection{Introducción}

La filtración es una operación común en la recuperación y purificación de los productos biotecnológicos. Entre sus aplicaciones más frecuentes se encuentran la separación de biomasa y componentes insolubles de los medios de cultivo, la clarificación de soluciones y la concentración y purificación de proteínas u otras biomoléculas y productos de fermentación. Los medios de filtración mas empleados en estos procesos son las telas filtrantes, en algunos casos con ayudantes de filtración y los filtros de profundidad y de membrana que son estructuras microporosas de celulosa, ésteres de celulosa, nylon, PVDF, policarbonato, fibra de vidrio, etc., con tamaños de poro en el rango de 0.2-10 $\mu \mathrm{m}$ [Gabler, 1985; Brocklebank, 1990]. Los materiales que constituyen estos medios de filtración suelen tener la propiedad de 
adsorber biomoléculas, fenómeno no siempre tenido en cuenta al procesar soluciones de proteína. Mas aún, las propiedades adsorbentes de estos materiales constituyen la base de una gran variedad de métodos bioquímicos analíticos y preparativos [Tovey and Baldo, 1989; Scott et al., 1995]. La adsorción depende de las propiedades intrínsecas de la biomolécula, de las propiedades superficiales del material y las condiciones del entorno [Hlady and Buijs, 1996; Nicolau and Nicolau, 1999]. En el Capítulo 2 se describió el fenómeno de adsorción de cierta actividad poligalacturonasa producida por A. kawachii en el medio glucosa/triptona, a filtros de fibra de vidrio (FFV). Estos filtros se emplearon rutinariamente para clarificar las soluciones de enzima como paso previo a los procesos de concentración o de cromatografía. Sobre la base de las curvas de pH/actividad PGasa determinadas antes y después de la filtración del medio de cultivo por FFV, se estableció que A. kawachii en el medio glucosa/triptona produce al menos dos grupos de PGasas. Un grupo corresponde a las enzimas activas a pH 2.0 pero inactivas a pH 5.0, que no se adsorben al FFV. La enzima predominante en este grupo es PGI. El otro grupo son las PGasas activas a $\mathrm{pH} 5.0$ pero inactivas a $\mathrm{pH} 2.0$ que se adsorben al FFV. El fenómeno de adsorción resultó altamente selectivo para las PGasas. Dado lo interesante del fenómeno observado, se investigó con mayor detalle la adsorción y posterior elución de estas proteínas al filtro. Posteriormente las PGasas adsorbidas fueron purificadas por métodos cromatográficos convencionales. En este Capítulo se describe el fenómeno de adsorción/desorción de las PGasas a FFV, la utilización de la filtración como método integrativo para la purificación de las enzimas y la parcial caracterización de las enzimas purificadas.

\subsection{Materiales y métodos}

\subsubsection{Reactivos y soluciones buffer}

Pectina cítrica (85 \% de ácido anhidrogalacturónico, grado de metoxilación GM, 53 \%), ácido poligalacturónico (APG, sal sódica, 90 \% de ácido anhidrogalacturónico) y membranas de celulosa para diálisis (corte $12400 \mathrm{Da}$ ), hemoglobina, carboximetilcelulosa (CMC, sal sódica), almidón soluble (AS) fueron obtenidos de Sigma. Sepharose SP Fast Flow, Sephacryl S-100, Concavalina A-Sepharose 4B (ConA-Sepharose), columnas PD-10, patrones de proteína de bajo peso molecular (14.4 a $94 \mathrm{kDa})$ para electroforesis, anfolitos para isoelectroenfoque (IEF) en el rango de $\mathrm{pH}$ 3.0-10 (Pharmalyte) y patrones de pI de amplio rango (pI 3.5-9.3) fueron obtenidos de Pharmacia Biotech. Como fuente de PGasa de A. niger se utilizó el producto de Megazyme (ver Capítulo 3). La endo-PGasa de Trichosporum penicillatum (Geotrichum klebanii) fue proporcionada por el Dr. Takuo Sakai de la Universidad Prefectural 
de Osaka, Japón. La actividad del producto fue de 110 U/mg (APG, pH 5.0, reductores Somogyi-Nelson) y la actividad específica 1600 U/mg proteína. Los productos fueron disueltos en BCP pH 5.0, pasados por PD-10 y analizados por SDS-PAGE (Figura 5.1). En el caso de G. klebanii se obtuvo una banda de $41 \pm 1.09 \mathrm{kDa}$, que coincide con el valor reportado para esta proteína [Sakai et al., 1993], y en el caso del producto de A. niger dos bandas de peso molecular muy próximo: $40.5 \pm 1.1$ y $42.2 \pm 1.1 \mathrm{kDa}$, lo cual difiere significativamente de lo reportado por el fabricante. Este producto de A. niger muestra además una gran heterogeneidad en IEF (ver Figura 5.8). El pI reportado para la PGasa de G. klebanii es 7.7 [Sakai et al., 1993]. El preparado Rapidase FP Super ${ }^{\circledR}$ (Gist-brocades) fue utilizando como fuente de pectin-metilesterasa (PME, EC 3.1.1.11) de Aspergillus niger. La actividad del producto fue $780 \mathrm{U} / \mathrm{ml}$. Como fuente de pectin-liasa (PeL; EC 4.2.2.11) se utilizó el preparado Pectolyase (Sigma) proveniente de A. japonicus. El producto presentó una actividad de $1.2 \mathrm{U} / \mathrm{mg}$.

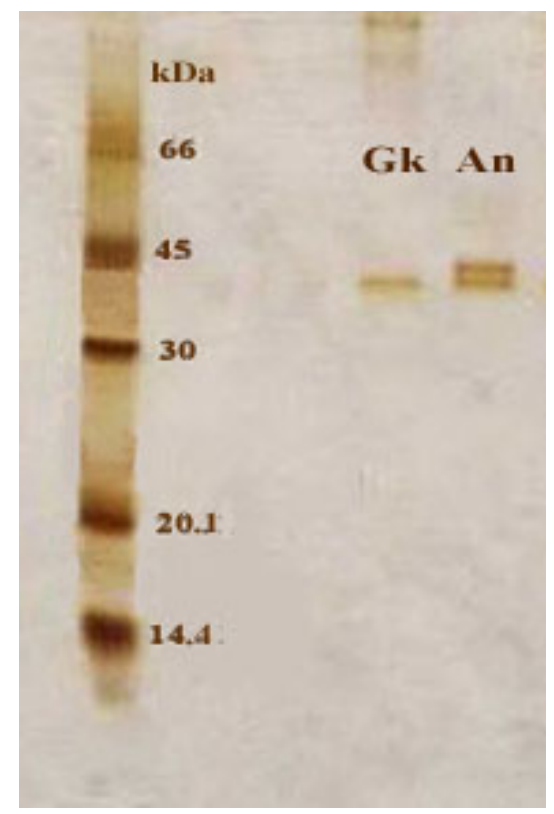

Figura 5.1. SDS-PAGE de poligalacturonasas de G. klebanii y A. niger Siembra: G. klebanii (Gk) 3.0 g proteína, A. niger (An) $1.0 \mu$ g proteína

La composición del buffer citrato-fosfato (BCP) fue la siguiente: ácido cítrico $50 \mathrm{mM}$, fosfato disódico 25 mM. El pH de la mezcla es 3.1-3.2. Cuando fue requerido, BCP se diluyó y/o su pH se modificó al valor deseado mediante el agregado de $\mathrm{HCl}$ o $\mathrm{NaOH}$. La dilución del buffer se expresa con una fracción (e.j. BCP 1/2 indica buffer BCP diluido a la mitad). 


\subsubsection{Microorganismo y medio de cultivo}

La cepa, composición del medio y las condiciones de cultivo en frascos agitados han sido descriptas en el Capitulo 3.

\subsubsection{Proceso de filtración}

La separación inicial del micelio se realizó filtrando el medio de cultivo a través de tela muselina. El líquido obtenido fue centrifugado (5000 g x 20 minutos) y el sobrenadante (medio centrifugado, $\mathrm{MC}$ ) congelado en recipientes de plástico $(500 \mathrm{ml}) \mathrm{a}-20^{\circ} \mathrm{C}$. Cuando se lo requirió, se descongeló en un baño a $37^{\circ} \mathrm{C}$. La filtración de $\mathrm{MC}$ u otras soluciones de enzima fue llevada a cabo utilizando un sistema de flujo directo (dead-ended system) [Koros et al., 1996] con soporte de polisulfona para medios de filtración de $47 \mathrm{~mm}$. En algunos casos se empleó un soporte de vidrio sinterizado de borosilicato (Millipore ${ }^{\circledR}$ ) en reemplazo del soporte de polisulfona. Los medios de filtración fueron obtenidos de OSMONICS. Se emplearon membranas de ésteres (acetato y nitrato) de celulosa (poro nominal $0.45 \mu \mathrm{m}$ ) y prefiltros de fibra de vidrio con binder (tipo G15, tamaño de poro nominal $0.5 \mu \mathrm{m}$ ) y sin binder (tipo G4, tamaño de poro nominal $1.0 \mu \mathrm{m}$ ). El proceso de filtración se efectuó mediante vacío a un caudal aproximado de 20-25 ml por minuto. Cada muestra fue filtrada tres veces (reciclando el permeado) para asegurar condiciones de equilibrio. El permeado fue recolectado en tubos de vidrio y conservado en hielo o congelado a $-20^{\circ} \mathrm{C}$ hasta su análisis. Todas las operaciones se realizaron a $20-25^{\circ} \mathrm{C}$.

\subsubsection{Ensayos de actividad enzimática}

La actividad PPasa, PGasa, PeL, proteasa ácida y medidas viscosimétricas con APG fueron determinadas según se describió en capítulos anteriores. La actividad PME fue determinada por titulación potenciométrica utilizando una solución de pectina cítrica (GM 53) al 0.5\% en agua a pH 4.5. Como agente neutralizante se empleó $\mathrm{NaOH} 0.1 \mathrm{M}$. La actividad amilasa se determinó incubando $400 \mu \mathrm{l}$ de solución de sustrato (1.2\% de AS en BCP, pH 5.0) con $100 \mu \mathrm{l}$ de solución de enzima durante 30-60 minutos, luego de lo cual la mezcla de reacción se enfrió en baño de hielo. La concentración de azúcares reductores en la mezcla de reacción se determinó por Somogyi-Nelson [1952] usando glucosa como estándar. La actividad celulasa fue determinada de la misma manera, excepto que se utilizó CMC como sustrato en lugar de almidón. El tiempo de reacción en este caso fue de 120-240 min. Una unidad de actividad enzimática (PPasa, PGasa, PeL, amilasa y celulasa) se define como la cantidad de enzima que 
produce un $\mu$ mol de azúcar reductor por minuto La actividad PME se expresa como $\mu$ moles de éster hidrolizado por minuto.

\subsubsection{Propiedades de las enzimas}

5.2.5.1. Relación pH-actividad. El efecto del $\mathrm{pH}$ en la actividad fue evaluado sobre APG, pectina cítrica y protopectina usando BCP en el rango de $\mathrm{pH} 2.0$ a 6.5 siguiendo el protocolo indicado en 3.2.5.

5.2.5.2. Estabilidad térmica. La estabilidad térmica de las PGasas fue determinada en el rango de pH 2.0 a 5.0 siguiendo la metodología descripta en 3.2.6.2.

\subsubsection{Técnicas bioquímicas}

Las etapas cromatográficas fueron realizadas con un equipo FPLC (Pharmacia/Amersham). Para la cromatografía de intercambio catiónico se empleó una columna Sepharose SP FF (1.6 x 20 cm, $140 \mathrm{ml}$ de gel), equilibrada con BCP pH 5.0 (1/4). Luego de aplicar la muestra, se lavó con dos volúmenes de buffer de equilibrio y las proteínas adsorbidas se eluyeron con un gradiente lineal de $\mathrm{NaCl}(0-500 \mathrm{mM})$ en buffer. El caudal fue de $0.75 \mathrm{ml} / \mathrm{min}$ y el volumen de fracción $5 \mathrm{ml}$.

La filtración por tamiz molecular fue realizada tal como se describió en la Figura 3.1 para PGI. El isoelectroenfoque (IEF) fue realizado en un sistema Mini IEF Cell (Bio-Rad). El gel se preparó con poliacrilamida y anfolitos en el rango 3.5-10 de acuerdo a las instrucciones del fabricante. Para la determinación del pI, el gel de IEF se tiñó con plata. La glicosidación de la PGasa fue evaluada determinando la adsorción a ConA-Sepharose tal como se describió en 3.2.8.

\subsection{Resultados}

\subsubsection{Adsorción de enzimas extracelulares de A. kawachii a medios de filtración}

En el medio glucosa/triptona A. kawachii produce bajos niveles de enzimas extracelulares (Capítulo 2). Las actividades enzimáticas más significativas en este medio correspondieron a las PGasas y a la proteasa ácida. Los valores típicos de proteína y actividad determinados entre las 30 y 40 h de cultivo (tiempo al cual no se detecta glucosa en el medio) fueron los siguientes: proteína 0.25-0.3 mg/ml, PGasa (reductores DNS) 1.0-5.0 U/ml (determinada a pH 5.0, PG5) y 0.08-0.25 U/ml (determinada a pH 2.0, PG2), proteasa ácida 3.5-4.7 U/ml, celulasa 3.0-5.0 mU/ml y amilasa 20-75 mU/ml. En la Tabla 5.1 se presentan los valores de concentración de proteína y de actividad enzimática en MC y en los permeados obtenidos luego de la filtración de MC a pH 3.0 por membranas de celulosa o por FFV. Con excepción 
de la PGasa ácida, las actividades enzimáticas en los permeados fueron menores que en MC. El efecto no fue uniforme y dependió de la combinación particular enzima/medio de filtración. Para celulasas, por ejemplo, la disminución mas significativa ocurrió con la membrana de celulosa, lo mismo para la actividad proteolítica. En cambio, para PG5, la disminución fué máxima con el FFV. Todas las actividades enzimáticas en MC a pH 3.0 fueron estables a temperatura ambiente (3 h de incubación a $20-25{ }^{\circ} \mathrm{C}$ ), por lo cual la menor actividad en el permeado se atribuyó en principio a la adsorción de las proteínas a los medios de filtración. Un experimento sencillo permitió confirmar esta hipótesis. Luego de filtrar MC, el medio de filtración se colocó en una caja de Petri con una solución de sustrato y se agitó lentamente. La presencia de actividad PGasa en el filtro se confirmó por el incremento de poder reductor de la solución de sustrato.

Los datos indicados en la Tabla 5.1 se refieren a FFV sin binder. Los mismos resultados se obtuvieron cuando se emplearon FFV fabricados con binder, en este caso una resina acrílica que se incorpora a las fibras para mejorar las propiedades de flujo del medio de filtración (datos no mostrados). Por lo tanto se concluyó que el binder no afecta la adsorción. Por otra parte y tal como se muestra en la misma Tabla, la adsorción de la actividad PGasa también ocurrió al filtrar MC a través de un soporte de vidrio sinterizado de borosilicato. Sobre la base de estos resultados y teniendo en cuenta que el vidrio borosilicato es tambien el constituyente de los FFV, se concluyó que este material es el adsorbente de las PGasas.

Una característica muy importante del fenómeno de adsorción fue la selectividad por las PGasas activas a pH 5.0. Los valores de concentración de proteína en MC y el permeado indican que solamente una pequeña fracción de la proteína total en MC se adsorbe al FFV ( $<10 \%$ ), mientras que la actividad PGasa se adsorbió casi en su totalidad. 
Tabla 5.1. Actividades enzimáticas y concentración de proteína determinadas antes y después de la filtración de cultivos de A. kawachii por diferentes filtros y membranas a $\mathrm{pH}$ 3.0.

\section{Actividad enzimática}

\begin{tabular}{|c|c|c|c|c|c|c|c|}
\hline & & $\begin{array}{l}\text { Proteína*** } \\
\text { (g/l) }\end{array}$ & $\begin{array}{c}\text { PGasa } 2.0 \\
(\mathrm{U} / \mathrm{ml})\end{array}$ & $\begin{array}{c}\text { PGasa } 5.0 \\
(\mathrm{U} / \mathrm{ml})\end{array}$ & $\begin{array}{l}\text { Amilasa } \\
(\mathrm{mU} / \mathrm{ml})\end{array}$ & $\begin{array}{l}\text { Proteasa } \\
(\mathrm{mU} / \mathrm{ml})\end{array}$ & $\begin{array}{c}\text { Celulasa } \\
(\mathrm{mU} / \mathrm{ml}))\end{array}$ \\
\hline \multicolumn{2}{|c|}{ MC* } & 0.32 & $0.11^{\mathrm{a}}$ & $1.54^{\mathrm{a}}$ & $79.2^{\mathrm{a}}$ & $3.98^{\mathrm{a}}$ & $3.45^{\mathrm{a}}$ \\
\hline \multicolumn{2}{|c|}{ Permeado** } & & & & & & \\
\hline Soporte & $\begin{array}{c}\text { Medio } \\
\text { filtración }\end{array}$ & & & & & & \\
\hline PS & FFV & 0.30 & $0.11^{\mathrm{a}}$ & $0.17^{b}$ & $74.3^{b}$ & $3.36^{b}$ & $2.56^{\mathrm{b}}$ \\
\hline PS & Ce & 0.30 & $0.11^{\mathrm{a}}$ & $1.45^{\mathrm{a}}$ & $59^{c}$ & $3.08^{b}$ & $1.90^{b}$ \\
\hline VBS & Ninguno & - & $0.109^{a}$ & $0.35^{c}$ & $68^{d}$ & $4.02^{\mathrm{a}}$ & - \\
\hline
\end{tabular}

* Cultivo en medio glucosa/triptona filtrado por tela muselina y centrifugado (MC).** Obtenido de la filtración de $50 \mathrm{ml}$ de MC a pH 3.0 tres veces (reciclando el filtrado) a una velocidad de flujo de $20-25 \mathrm{ml} / \mathrm{min}$ a $25^{\circ} \mathrm{C}$. ${ }^{* * *}$ Determinada después de dializar contra agua deionizada. Los valores con la misma letra no presentan diferencias significativa $(\mathrm{P}<0.05$, LSD).

PS polisulfona, VBS vidrio borosilicato, FFV filtro fibra de vidrio sin binder, Ce membrana de ésteres de celulosa. -: no determinada 


\subsubsection{Efecto del pH en la adsorción de las PGasas de A. kawachii y otras PGasas y pectinasas fúngicas}

Los fenómenos de adsorción suelen ser muy dependientes del $\mathrm{pH}$ del medio. Por tal motivo se investigó la adsorción de la actividad PGasa al FFV en función del pH de MC. Para determinar si la adsorción es específica de las enzimas de $A$. kawachii, el mismo ensayo se efectuó con dos PGasas fúngicas purificadas. Estas PGasas tienen en común con las PGasas de A. kawachii el hecho de ser activas a $\mathrm{pH} 5.0$ e inactivas a $\mathrm{pH}$ 2.0. Para el ensayo, los productos enzimáticos se disolvieron en BCP (1/4) al pH indicado en una concentración equivalente a 1.1-1.2 $\mu$ g proteína/ml. El volumen filtrado fue en todos los casos $50 \mathrm{ml}$. Los resultados se muestran en la Figura 5.2. La adsorción de la actividad PGasa de A. kawachii dependió marcadamente del $\mathrm{pH}$ de $\mathrm{MC}$, siendo máxima a $\mathrm{pH} \leq 3.0$ y negligible a pH 5.0. Los mismos resultados se obtuvieron con las enzimas de A. niger y G. klebanii. Por el contrario, la actividad PGasa ácida (PGI) no se adsorbió en todo el rango de pH ensayado (2.0-7.0).

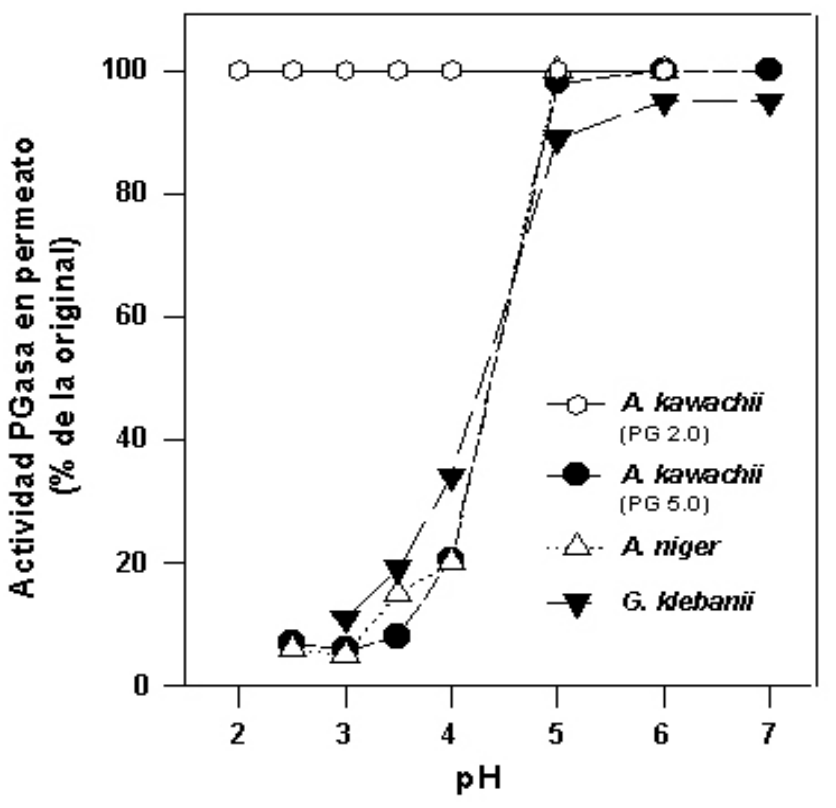

Figura 5.2. Efecto del $\mathrm{pH}$ en la adsorción de poligalacturonasas a filtros de fibra de vidrio.

Filtración: A. kawachii: 50 ml MC. G. klebanii y A. niger: 50 ml BCP (1/4) 1.5 g proteína/ml. El pH de MC o BCP se ajustó con $\mathrm{HCl}$ o $\mathrm{NaOH}$. Luego de filtrar, el pH de cada permeado se ajustó a 5.0 y se mantuvo en baño de hielo hasta la determinación de actividad. La actividad de las PGasas de G. klebanii y A. niger se determinó a pH 5.0 .

Otras pectinasas fúngicas, como PME y PeL, fueron también evaluadas en relación con su capacidad de adsorberse al FFV. Para tal fin se filtraron soluciones de de PME y PeL en BCP 
(1/4), pH 3.0 conteniendo 0.12-0.25 U/ml y 0.8-1.2 U/ml, respectivamente. Bajo las condiciones ensayadas, no hubo adsorción de PME, en cambio se adsorbió un 50\% de la actividad PeL (disminución relativa de actividad en el permeado respecto de la solución original).

\subsubsection{Desorción de la actividad PGasa.}

Un aspecto crítico en la utilización de la adsorción como fenómeno básico para la purificación de un producto, es la etapa de desorción o elución. Para estudiar la desorción de la actividad PGasa del FFV, se realizó una primera experiencia empleando como eluyente el permeado obtenido luego de filtrar MC a pH 3.0 (P3), reajustado en este caso a pH 5.0 (P35). Como la actividad PGasa no se adsorbe a pH 5.0, se especuló que dicho permeado podría ser un eluyente eficaz. Por otra parte, para mejorar la eficiencia de la separación eliminando los componentes no adsorbidos que pudieran quedar ocluidos en el filtro, se realizó un ensayo similar pero incluyendo un lavado del filtro previo a la elución. Como solución de lavado se empleó BCP (1/4) pH 3.0. Los resultados obtenidos se muestran en la Tabla 5.2. La actividad PGasa adsorbida al FFV fue efectivamente eluída con P35 con una recuperación del 90 \% respecto de la actividad original. Una segunda elución con P35 dió actividad negativa, por lo cual se concluyó que el proceso de adsorción/desorción inactiva, en este caso, un 10-12 \% de la actividad enzimática. Los mismos resultados se obtuvieron cuando el filtro se lavó con el buffer de pH 3.0 previo a la desorción, es decir el lavado no eluyó ni afectó la actividad adsorbida. Sobre la base de estos resultados se realizaron varias experiencias en las cuales se emplearon como eluyente diferentes soluciones buffer a pH 5.0 en reemplazo de P35. En todos los casos se determinó la conductividad de las soluciones como parámetro de su fuerza iónica. Cada ensayo consistió de cuatro filtraciones sucesivas por el mismo filtro (el volumen filtrado en todos los casos fue $50 \mathrm{ml}$ ): MC a pH 3.0 (adsorción), BCP (1/4) pH 3.0 (lavado), buffer a pH 5.0 (desorción) y P35 (el permeado obtenido de la filtración de MC a pH 3.0 reajustado a pH 5.0). Esta ultima operación se realizó para evaluar si hubo inactivación enzimática durante el proceso de adsorción/elución. Los resultados se indican en la Tabla 5.2. Todas las soluciones buffer eluyeron la actividad PGasa, dependiendo la eficiencia de extracción del pH y la fuerza iónica del medio pero no de la naturaleza del buffer (la misma actividad se eluyó con buffer acético/acetato y BCP a valores equivalentes de fuerza iónica y pH). El efecto del pH en la desorción se evidencia claramente con BCP (1/4). A pH 3.0 (buffer de lavado) no hubo elución de actividad, en cambio a pH 5.0 se extrajo, en una etapa, el 44 \% de la actividad enzimática. Al incrementar la fuerza iónica del medio (a pH 5.0), ya 
sea por incremento de la concentración del buffer o por el agregado de $\mathrm{NaCl}$, la actividad PGasa se desorbió en alta proporción del FFV. La máxima recuperación de actividad con las soluciones buffer fue del 72-75 \%, es decir inferior a la obtenida con P35. La elución final con P35 en las experiencias con los diferentes eluyentes permitió recuperar únicamente un 4-6 \% de actividad inicial en los ensayos con BCP, y un 20 \% cuando se empleó como eluyente $\mathrm{NaAcO}$. Se puede inferir de estos datos que la adsorción y posterior elución con BCP inactiva aproximadamente el 15-20 \% de la actividad PGasa original. Si bien el uso de NaAcO podría, luego de optimizar la extracción, dar un rendimiento mayor, las PGasas son menos estables en este buffer en comparación con BCP, por consiguiente este último se empleó como eluyente de la actividad PGasa.

Un dato que llama la atención es la eficiencia de P35 para eluir la actividad adsorbida. La fuerza iónica del permeado probablemente sea la mínima requerida para desorber la actividad PGasa, sin embargo la actividad eluída con P35 fue en promedio un 15 \% mayor que la obtenida con las soluciones buffer que tienen incluso una mayor fuerza iónica. Parte de esta eficiencia debe atribuirse en realidad a la menor desnaturalización que ocurre cuando se eluye con el permeado, ya que los procesos de adsorción y lavado fueron comunes en todos los ensayos. Esta protección es mas notoria cuando se compara P35 con la elución realizada con BCP. Cabe mencionar que A. kawachii es un gran productor de ácido cítrico, por lo cual es muy probable que este componente del buffer BCP también se encuentre en P35. Por otra parte el agregado de triptona o sales como sulfato de magnesio o cloruro férrico a BCP, no mejoraron la recuperación de la actividad adsorbida. Las diferencias de rendimiento entre BCP y P35 probablemente se relacione con cierto efecto inactivante del buffer o bien a la presencia en el permeado de algunos productos generados durante el cultivo que protejen a la PGasa.

La desnaturalización de proteínas cuando estas se adsorben a superficies es independientemente del mecanismo que predomine en la interacción entre el adsorbato y la superficie (electrostática, hidrofóbica, afinidad), y se relaciona con distorsiones en la estructura que provoca la fijación (y desorción ?) de la molécula a la superficie [Quiquampoix et al, 1995]. La desnaturalización de la proteína que genera el proceso mismo de adsorción/desorción es probablemente un factor determinante en el rendimiento de la etapa de purificación. 
Tabla 5.2. Adsorción y desorción de la actividad PGasa de A. kawachii a filtros de fibra de vidrio.

\begin{tabular}{cccc}
\hline $\begin{array}{c}\text { Solución } \\
\text { enzimática }\end{array}$ & Conductividad \# & $\begin{array}{c}\text { Actividad PGasa } \\
\text { (U/ml) }\end{array}$ & $\begin{array}{c}\text { Recuperación } \\
(\%) * *\end{array}$ \\
\hline MC & 400 & 3.29 & - \\
Adsorción & & & - \\
P5 & 428 & 3.22 & - \\
P3 & 450 & 0.06 & \\
Lavado & & & - \\
BCP (1/4) & 320 & 0 & \\
(pH 3.0) & & & 88 \\
Desorción & & $2.9(0)$ & $74.5(16)$ \\
P35 & 470 & $2.45(0.55)$ & $44(26.5)$ \\
NaACO & 872 & $1.44(0.87)$ & $74.5(4.2)$ \\
BCP (1/4) & 290 & $2.45(0.14)$ & $72(4.2)$ \\
BCP (1/4) + & 2000 & $2.4(0.14)$ & $72(6.4)$ \\
NaCl 0.17 M & 926 & $2.4(0.21)$ & \\
BCP & 1800 & &
\end{tabular}

Condiciones de filtración: ver Tabla 5.1 MC: medio filtrado por tela muselina y centrifugado, P5 y P3: permeados obtenidos de la filtración de MC a pH 5.0 y 3.0 respectivamente P35: P3 al cual se ajustó el pH a 5.0 con $\mathrm{NaOH}$ BCP: $50 \mathrm{mM}$ ácido cítrico, $25 \mathrm{mM} \mathrm{Na}_{2} \mathrm{HPO}_{4}$, pH 5.0. NaAcO: $150 \mathrm{mM}$ ácido acético ajustado a pH 5.0 con $\mathrm{NaOH}$..

Lavado: $50 \mathrm{ml}$ buffer. Desorción: $50 \mathrm{ml}$ de la solución indicada seguida de $50 \mathrm{ml}$ de P35.

* Medida a pH 5.0. Cuando la actividad se midió en las soluciones buffer, se adicionó a la mezcla de reacción medio inactivado (P35 tratado 5 min a $100{ }^{\circ} \mathrm{C}$ ) en cantidad equivalente a la presente cuando la actividad se determinó en MC o los permeados.

Las actividades en MC, P3 y P35 son el promedio de todos los ensayos (cada ensayo un eluyente diferente), entre paréntesis se indica la actividad eluída con P35.

** \% de la actividad presente en MC, entre paréntesis se indica el \% de la actividad presente en MC eluída con P35. \# Valor extrapolado para una dilución 1/10 en agua. Referencia KCl 0.01 M = 1400.

\subsubsection{Efecto de la composición del medio en la adsorción}

En los anteriores ensayos, se determinó el efecto del pH en la adsorción y del pH y fuerza iónica en la desorción o elución. Resultó interesante evaluar el efecto de la fuerza iónica y ciertos compuestos como detergentes, en la adsorción de la actividad PGasa de G. klebanii a FVV a pH 3.0, es decir al pH de máxima adsorción de la proteína. La PGasa de G. klebanii se empleó como proteína modelo ya que el producto presentó homogeneidad en el análisis por SDS-PAGE. El ensayo con detergentes (octyl-glucósido, Tween 80 y Triton X-100) se realizó para determinar si la interacción hidrofóbica es importante en la adsorción [El Rassi et al., 1990 ]. Cada experiencia consistió de tres etapas sucesivas de filtración por el mismo filtro: 
buffer de ensayo (adsorción), BCP (1/4), pH 3.0 (lavado) y BCP, pH 5.0 (elución). Los resultados obtenidos se muestran en la Tabla 5.3. Se observa que la adsorción decrece a medida que aumenta la fuerza iónica del medio y no es afectada por detergentes (a baja fuerza iónica). La enzima adsorbida a pH 3.0 y baja fuerza iónica se eluyó variando simplemente el pH de BCP tal como se determinó en el estudio anterior. Obviamente cuando la solución de PGasa se filtró en este buffer no ocurrió adsorción.

Tabla 5.3. Efecto de la composición del medio en la adsorción de la PGasa de G. klebanii a filtros de fibra de vidrio.

\begin{tabular}{cccccc}
\hline & \multicolumn{5}{c}{ Actividad PGasa (U/ml)* } \\
\hline Medio buffer & $\begin{array}{c}\text { Conductividad } \\
(\mathbf{1 : 1 0})\end{array}$ & SE & Pe & L & E \\
\hline BCP (1/4), pH 3.0 & 160 & 1.57 & 0.078 & 0 & 1.28 \\
$+\quad 0.15 \mathrm{M} \mathrm{NaCl}$ & 2275 & 1.62 & 0.52 & 0 & 0.85 \\
$+0.5 \mathrm{M} \mathrm{NaCl}$ & 6380 & 1.6 & 1.32 & 0 & 0.06 \\
$+1.0 \mathrm{M} \mathrm{NaCl}$ & 12710 & 1.67 & 1.59 & 0 & 0 \\
$+0.05 \%$ octil- & 158 & 2.09 & 0.033 & 0 & 1.4 \\
glucósido*** & 1034 & 1.88 & 0.12 & 0 & 1.42 \\
BCP (x 2), pH 3.0 & 1130 & 1.58 & 1.54 & - & - \\
\hline BCP, pH 5.0 & & & & & \\
\hline
\end{tabular}

Condiciones de filtración: ver Tabla 5.1. SE: solución de enzima (1.15 $\mu$ g proteína/ml en el buffer indicado) Pe: permeado obtenido de la filtración de SE L: permeado obtenido del lavado con BCP (1/4), pH 3.0. E: eluído (permeado obtenido de la filtración con BCP, pH 5.0). BCP: $50 \mathrm{mM}$ ácido cítrico, $25 \mathrm{mM}$ $\mathrm{Na}_{2} \mathrm{HPO}_{4} * \mathrm{~A}$ pH 5.0 (reductores: Somogyi-Nelson). En todos los casos el volumen filtrado fue $25 \mathrm{ml}$. ** Valor extrapolado para una dilución $1 / 10$ en agua. Referencia $\mathrm{KCl} 0.01 \mathrm{M}=1400$. *** Los mismos resultados se obtuvieron con Tween 80 y Triton X-100 al $0.1 \%$.

\subsubsection{Isotermas de equilibrio para la actividad PGasa.}

Para caracterizar el proceso de adsorción de la actividad PGasa de MC a FFV, se determinó la isoterma de adsorción. Las isotermas se construyen generalmente utilizando una cantidad fija de adsorbente y variando la concentración del adsorbato. Una vez establecido el equilibrio se determina la cantidad de adsorbato remanente en la fase soluble. En este caso la actividad PGasa en MC es un valor fijo (pero no constante pues varió en los diferentes cultivos batch), por lo tanto para incrementar la cantidad de PGasa en contacto con el filtro se varió el volumen de filtración. La experiencia consistió en filtrar sucesivamente y por el mismo filtro volúmenes de $50 \mathrm{ml}$ de $\mathrm{MC}$ ajustado a $\mathrm{pH}$ 3.0, midiendo luego de cada filtración 
la actividad PGasa en el permeado. La actividad adsorbida (teórica) se determinó por balance asumiendo que no ocurren pérdidas de actividad en el proceso de filtración. La Figura 5.3 muestra la relación existente entre la actividad adsorbida y el volumen filtrado. La adsorción se incrementó con el volumen y se saturó con $750 \mathrm{ml}$ de MC equivalente a 500 U/filtro. Este valor no representa la máxima capacidad de adsorción del filtro, sino el valor de equilibrio con la actividad PGasa en MC. Debido a las condiciones de equilibrio el porcentaje de PGasa adsorbida disminuye con el volumen filtrado. El volumen óptimo de MC para la adsorción fue 300 ml/filtro, de este modo se adsorbe aproximadamente el $95 \%$ de la actividad original. Este volumen representa un balance adecuado entre la retención de la PGasa y la eficiente utilización de la capacidad adsorbente del filtro

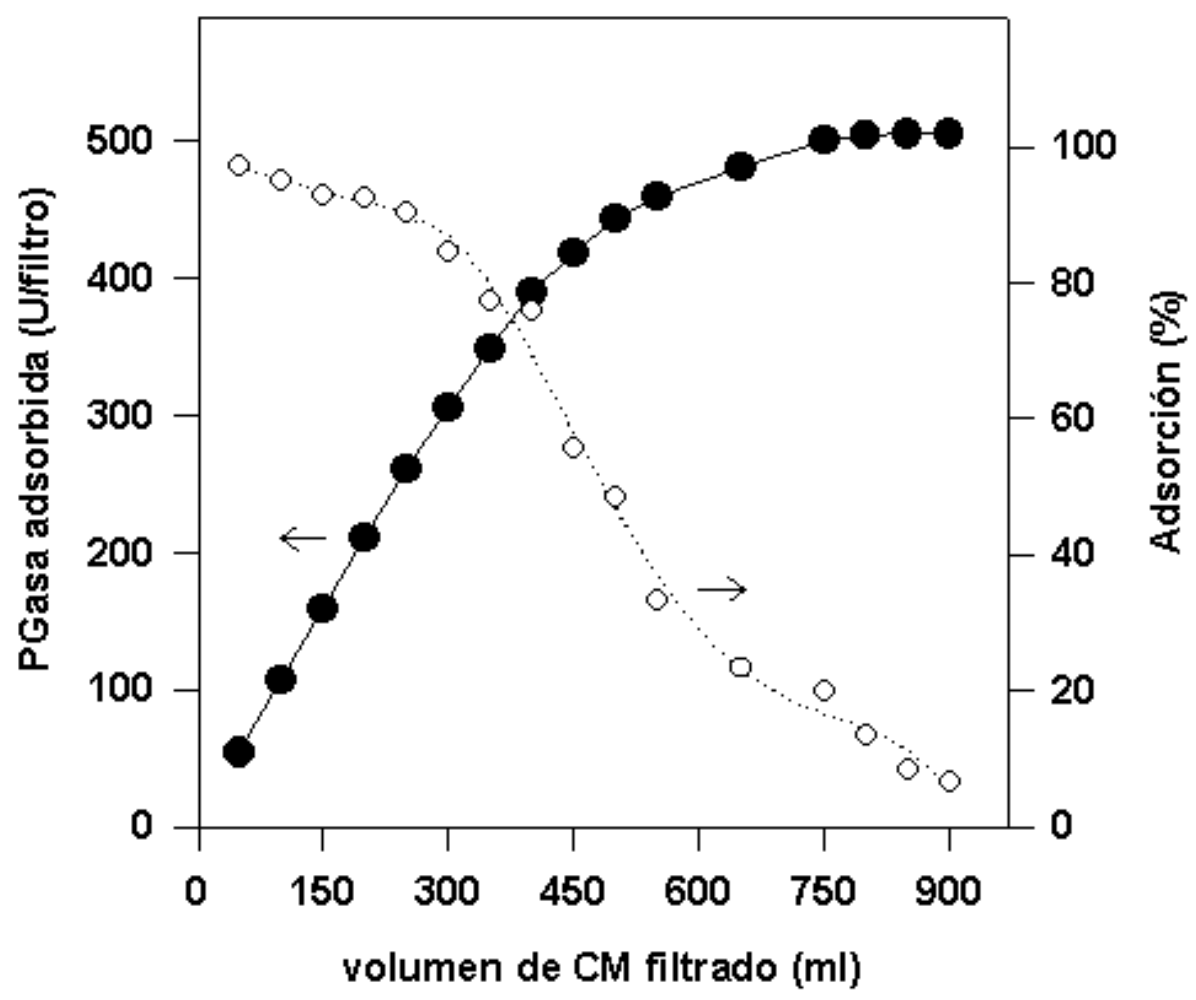

Figura 5.3. Adsorción de la actividad PGasa de A. kawachii a filtros de fibra de vidrio.

Para la obtención de la curva se filtraron $750 \mathrm{ml}$ de MC a pH 3.0 en fracciones de 50 ml. Luego de cada filtración, el pH del permeado se reajustó a 5.0 y se determinó la actividad PGasa. Las unidades adsorbidas se calcularon a partir de los valores de actividad (A) en MC y el permeado (p): ( $\left.A_{M C}-A_{P}\right) x$ 50. Las condiciones de filtración fueron las descriptas en la Tabla 5.1 La actividad PGasa se determinó a pH 5.0 midiendo reductores por DNS. La actividad de MC fue $~ 1.2 \mathrm{U} / \mathrm{ml}$. 


\subsubsection{Recuperación de la actividad PGasa adsorbida.}

Para optimizar la recuperación de la PGasa adsorbida, se filtraron $300 \mathrm{ml}$ de MC, se lavó el filtro con $10 \mathrm{ml}$ de buffer BCP (1/4), pH 3.0, y finalmente se procedió a la elución de la actividad adsorbida filtrando volúmenes sucesivos de $5 \mathrm{ml}$ de BCP, pH 5.0. La máxima recuperación, $83 \%$, se obtuvo con tres etapas de elución (Figura 5.4). Sin embargo dos etapas de elución resultan suficientes para evitar una dilución excesiva de la solución enzimática. De esta forma se recuperó el 79 \% de la actividad original y se concentró la actividad cuatro veces repecto de MC. Resultados similares se obtuvieron eluyendo con P35, pero en este caso la recuperación fue mayor (88 \%). Estos resultados son consistentes con los obtenidos en el ensayo de elución (ver 5.3.3).

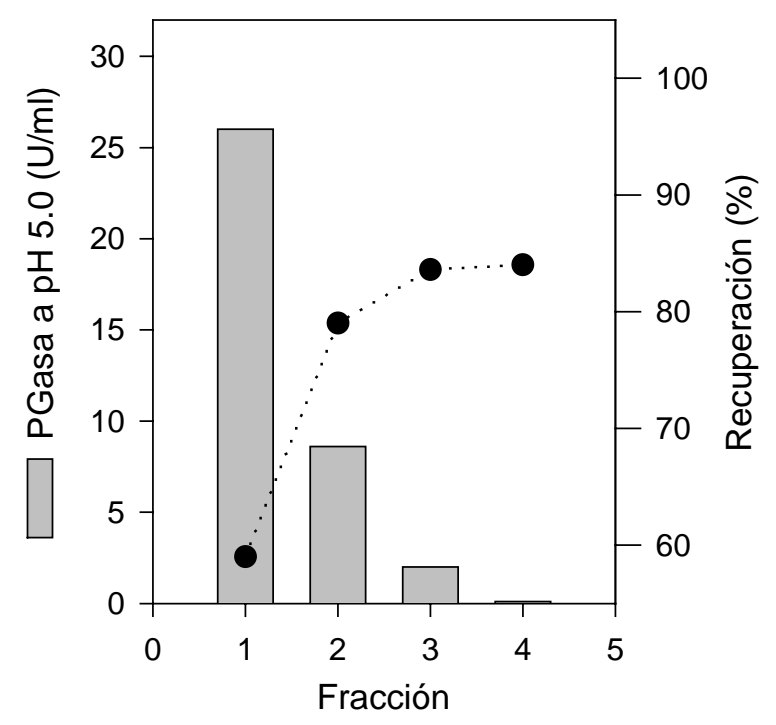

Figura 5.4. Elución de la actividad PGasa de A. kawachii adsorbida a filtros de fibra de vidrio.

Se filtraron $300 \mathrm{ml}$ de MC a pH 3.0 en fracciones de $50 \mathrm{ml}$. El filtro se lavó con $10 \mathrm{ml}$ de BCP (1/4), pH 3.0. La elución se efectuó filtrándo volúmenes (fracción) de $5 \mathrm{ml}$ de BCP, pH 5.0. Las condiciones de filtración fueron las descriptas en la Tabla 5.1

\subsubsection{Purificación de las PGasas}

La parte final del presente trabajo consistió en la purificación de las PGasas adsorbidas. El material de partida fueron $900 \mathrm{ml}$ de MC con una actividad PGasa de $4.9 \mathrm{U} / \mathrm{ml}$. La adsorción a FFV constituyó el primer paso del proceso de purificación, y se realizó tomando en cuenta los resultados previamente descriptos, es decir se filtraron $300 \mathrm{ml}$ de MC/filtro, se realizó 
luego un lavado del filtro con $10 \mathrm{ml}$ de buffer y se eluyó la actividad PGasa con dos volúmenes de $5 \mathrm{ml}$ de BCP, pH 5.0. Los eluídos provenientes de los tres batch de filtración se mezclaron y dializaron. Las PGasas contenidas en el dializado se purificaron mediante cromatografía de intercambio catiónico (Sepharose SP FF) y tamiz molecular (Sephacryl S100). En la Figura 5.5 se presenta un esquema de la purificación de las PGasas y en la Tabla 5.4 se resumen los datos del proceso del purificación.

\section{Medio de cultivo}

Filtración por tela muselina, centrifugación (MC)

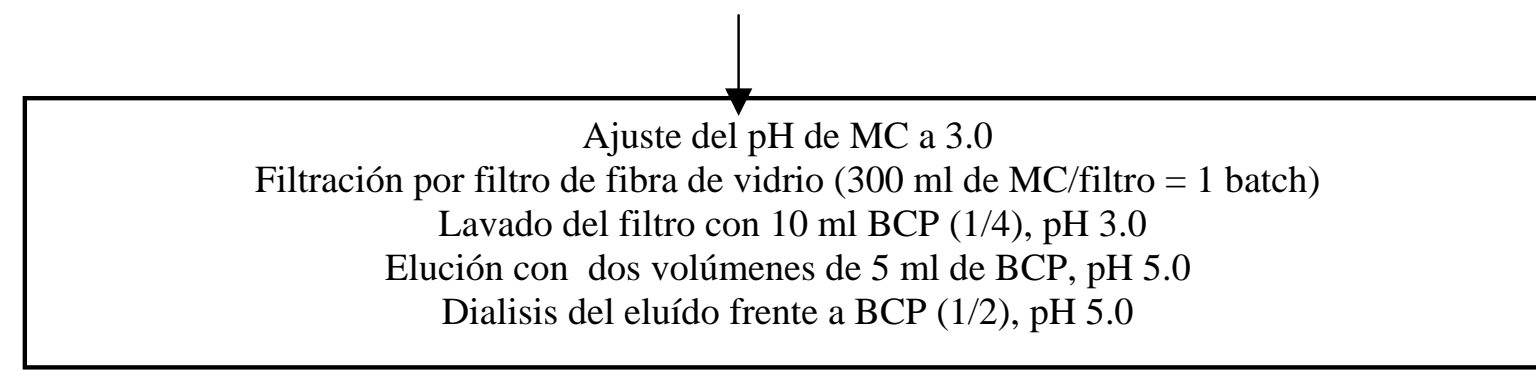

Cromatografía con Sepharose SP FF (XK 26/40, $140 \mathrm{ml}$ gel)

Buffer de equilibrio BCP (1/2) pH 5.0.

Muestra: $30 \mathrm{ml}$ de eluido dializado (tres batch de filtración)

Lavado columna: $300 \mathrm{ml}$ buffer

Elución: gradiente 0-0.5 M NaCl en buffer. Caudal: $5 \mathrm{ml} / \mathrm{min}$. Volúmen fracción: $5 \mathrm{ml}$.

Combinación de las fracciones que contienen actividad y diálisis frente a BCP (1/5), pH 5.0

Liofilización de los dializados

Sephacryl S-100 (XK 16/70, $100 \mathrm{ml}$ gel)

Buffer de equilibrio: BCP (1/2) pH 5.0. Muestra: $1 \mathrm{ml}$ (liofilizados de la cromatografía en

Sepharose). Caudal: $0.5 \mathrm{ml} / \mathrm{min}$. Volumen de fracción: $2 \mathrm{ml}$

Combinación de las fracciones que contienen actividad y diálisis frente a BCP (1/10), pH 5.0

Liofilización final

Figura 5.5. Esquema de la purificación de las PGasas activas a pH 5.0 producidas por A. kawachii en el medio glucosa/triptona.

Table 5.4. Resumen de la purificación de las PGasas activas a pH 5.0 producidas por A. kawachii en el medio glucosa/triptona. 


\begin{tabular}{|c|c|c|c|c|c|c|}
\hline $\begin{array}{c}\text { Etapa de } \\
\text { purificación }\end{array}$ & $\begin{array}{l}\text { Volumen } \\
\text { (ml) }\end{array}$ & $\begin{array}{l}\text { Proteína } \\
\text { (mg) }\end{array}$ & $\begin{array}{l}\text { Actividad } \\
\text { (U) }\end{array}$ & $\begin{array}{c}\text { Actividad } \\
\text { específica* } \\
\text { (U/mg) }\end{array}$ & $\begin{array}{c}\text { Rendimiento } \\
(\%)\end{array}$ & $\begin{array}{c}\text { Purificación } \\
-\end{array}$ \\
\hline MC & 900 & $300^{a}$ & 4200 & 13.9 & 100 & - \\
\hline $\begin{array}{c}\text { Adsorción a FFV } \\
\text { /Elución }\end{array}$ & 30 & 1.47 & 2820 & 1511 & 67 & 109 \\
\hline \multicolumn{7}{|l|}{ Sepharose $\mathbf{S P}^{\mathbf{b}}$} \\
\hline PG-II (Ak-2) & 40 & $\sim 0.43^{*}$ & 1790 & 4160 & 38 & 326 \\
\hline PG-III (Ak-3) & 30 & negligible & 43 & - & 1 & - \\
\hline \multicolumn{7}{|l|}{ Sephacryl S-100' } \\
\hline PG-II (Ak-2) & 40 & $\sim 0.16^{*}$ & 700 & 4370 & 17 & - \\
\hline PG-III (Ak-3) & 30 & negligible & 12 & - & 0.28 & - \\
\hline
\end{tabular}

* Actividad medida con 0.5 \% PGA en BCP, pH 5.0.

a dializado frente a BCP $(1 / 2) \mathrm{pH} 5.0$

b Las fracciones conteniendo actividad PGasa se mezclaron, dializaron contra BCP buffer (1/5), y liofilizaron. Para la cromatografía de tamiz molecular se reconstiyuyeron en $1 \mathrm{ml}$ del mismo buffer.

${ }^{\mathbf{c}}$ Las fracciones conteniendo actividad PGasa se combinaron, dializaron frente a BCP (1/10) pH 5.0 se distribuyeron en volúmenes de 0.5 a $2 \mathrm{ml}$ en frasquito de vidrio y liofilizaron. Cuando se requirió, los liofilizados se reconstituyeron con agua deionizada a una concentración $\sim 10 \mathrm{x}$ respecto del volúmen original

* valores estimados al reconstituir los liofilizados.

En el proceso global de purificación, la filtración por FFV resultó ser la operación mas relevante ya que el factor de purificación para esta etapa fue $>100$, lo cual demuestra la alta selectividad del proceso de adsorción. Como el material de partida para la purificación (MC) presentó en este caso una mayor actividad PGasa, en comparación con la registrada en los ensayos anteriores, el eluído resultó concentrado 20 veces respeto a MC. Para la siguiente etapa de purificación se recurrió a la cromatografía de intercambio catiónico que es también una técnica de alta resolución. En la Figura 5.6 se muestra el perfil de elución de la actividad PGasa en la cromatografía llevada a cabo con Sepharose SP, donde se observa la presencia de dos fracciones con actividad, que se denominaron PGII y PGIII. La fracción mayoritaria PGII, representó el 98 \% de la actividad PGasa total. Esta fracción eluyó con una concentración de $\mathrm{NaCl}$ de $\sim 0,075 \mathrm{M}$, mientras que PGIII eluyó a 0.27 M NaCl. Las fracciones conteniendo los respectivos picos de actividad se dializaron y liofilizaron para concentrar. Finalmente se purificaron por tamiz molecular. En la cromatografía con Sephacryl S-100 ambas muestras 
presentaron un pico homogéneo de actividad (Figura no mostrada). Para evaluar la purificación en las diferentes etapas se efectuó un análisis por SDS-PAGE (Figura 5.7). El eluído del FFV presentó dos bandas de proteína de peso molecular muy cercano que coinciden con las bandas que aparecen en cada pico de la cromatografía de intercambio catiónico, siendo además consistente la intensidad de las bandas con las actividades relativas de los picos. Este análisis confirma el alto grado de purificación de las PGasas eluidas del FFV en consistencia con lo que sugieren los datos de proteína y actividad enzimática.

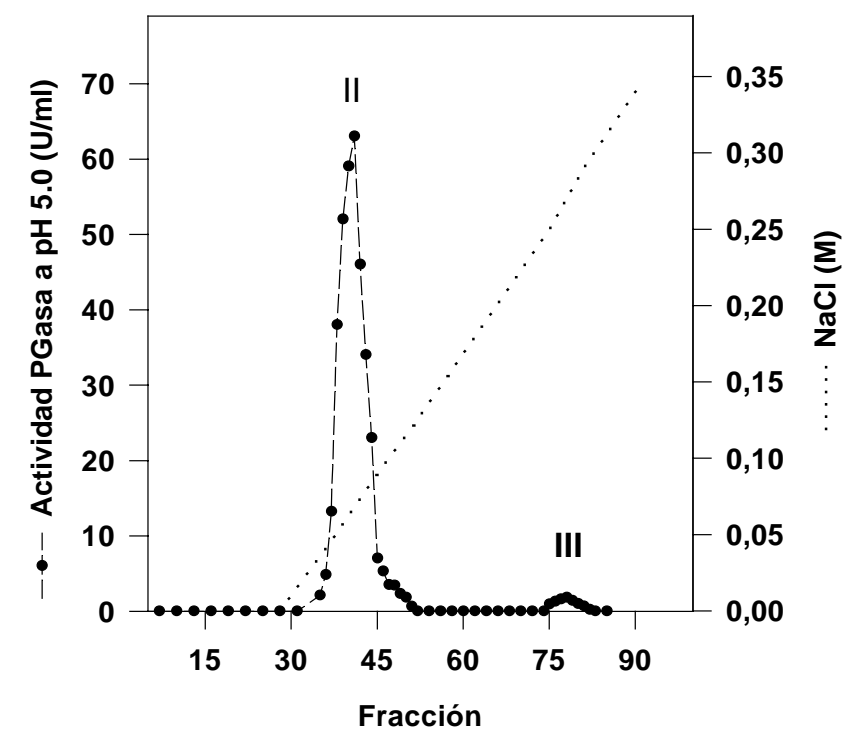

Figura 5.6. Cromatografía de intercambio catiónico (Sepharose SP) de la actividad PGasa eluída del filtro de fibra de vidrio.

Las condiciones de la cromatografía se describen en el esquema de la Figura 5.5. 


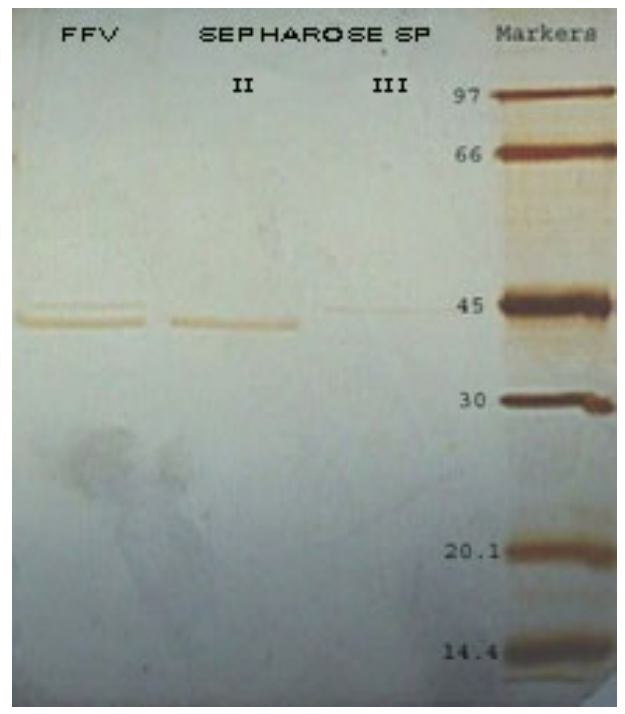

Figura 5.7. SDS-PAGE del proceso de purificación de la actividad PGasa adsorbida a filtros de fibra de vidrio.

FFV: eluído del filtro, $10 \mu \mathrm{l}$. Sepharose SP, $10 \mu \mathrm{l}$ picos II y III respectivamente.

El rendimiento final de la actividad PGasa fue del $17 \%$, muy inferior si se la compara con el rendimiento de PGI. Cabe mencionar que estas PGasas, a diferencia de PGI, son sensibles al congelamiento/descongelamiento y la deshidratación. Por ejemplo, luego de mantener MC 1 año a $-20{ }^{\text {aC}} \mathrm{C}$, la actividad PGI (medida a pH 2.0) no se modificó respecto del valor original, mientras que la actividad PGasa a pH 5.0 fue negligible, lo cual indica que estas enzimas se inactivaron durante el almacenamiento. La mayor pérdida de actividad durante la purificación ocurrió durante la liofilización. Las muestras liofilizadas finales reconstituidas con agua deionizada a una concentración 10-20 x respecto del volumen original, presentaron una actividad de $200 \mathrm{U} / \mathrm{ml}$ y $10 \mathrm{U} / \mathrm{ml}$ (APG, pH 5.0) para PGII y PGIII respectivamente. Estas soluciones se emplearon para caracterizar las PGasas.

\section{3.7. Caracterización bioquímica de las PGasas}

Los pesos moleculares de PGII y PGIII estimados por SDS-PAGE fueron $41.1 \pm 1.08$ y $43.6 \pm$ $1.07 \mathrm{kDa}$, mientras que los estimados por tamiz molecular fueron $37.8 \pm 1.03$ y $35.5 \pm 1.03$ respectivamente. Estos resultados indican que PGII y PGIII son proteínas monoméricas. PGII fue también analizada mediante IEF. La muestra resultó altamente homogénea, predominando una banda de pI $5.33 \pm 0.2$ (Figura 5.8). La banda superior apenas perceptible, tiene un pI de $5.1 \pm$ 0.2. Con fines comparativos también se analizó por IEF la PGasa de A. niger. 
Inesperadamente este producto comercial presentó una gran microheterogeneidad con numerosas bandas que enfocaron en un rango de pI comprendido entre 4.7 y 7.32. Probablemente sean isoformas de poligalacturonasa, ya que el análisis SDS-PAGE del producto mostró unicamente dos bandas de proteína (ver Figura 5.1). PGII se adsorbió a ConA-Sepharose lo cual sugiere que es una glicoproteína. El pI y la glicosidación de PGIII no se determinaron.

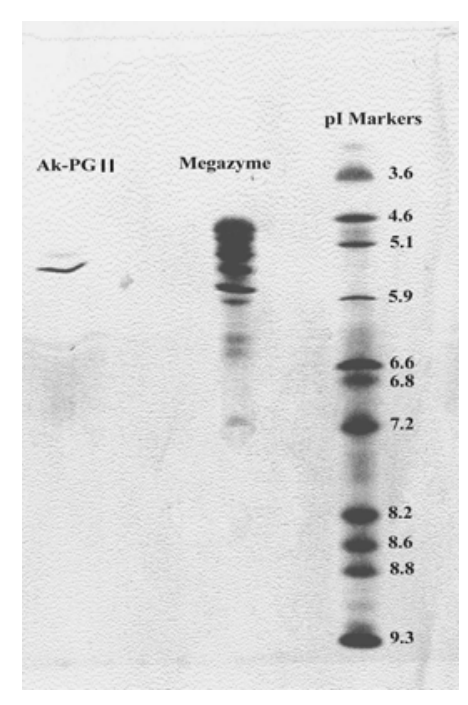

Figura 5.8. IEF de PGII de A. kawachii y PGasa de A. niger (Megazyme).

Las condiciones del IEF se describen en Materiales y Métodos. Los geles fueron teñidos con plata. PGII: muestra liofilizada proveniente de la cromatografía por tamiz molecular siembra $1.0 \mu \mathrm{g}$ de proteína.

\subsubsection{Propiedades de las enzimas}

\subsubsection{Efecto de $\mathrm{pH}$ sobre la actividad enzimática}

El perfil pH/actividad de PGII para diferentes sustratos y de PGIII para APG se muestra en la Figura 5.9. Los perfiles de actividad PGII sobre APG y protopectina son muy similares presentando un máximo alrededor de 4.6-4.7 y una actividad muy baja o negligible a $\mathrm{pH}<$ 3.0. Para pectina, en cambio, el máximo se desplaza hacia una región mas ácida, alrededor de $\mathrm{pH}$ 3.0, siendo incluso muy significativa la actividad a $\mathrm{pH}$ 2.0. A pH 5.5, PGII es prácticamente inactiva. Por su parte PGIII muestra actividad hasta $\mathrm{pH}$ 6.0, con un máximo de actividad sobre APG alrededor de 5.0. Si bien la actividad PGasa a pH 6.0 no se detectó cuando se empleó MC (ver Figura 5.7) esto es debido a la baja concentración de PGIII en el medio. Al purificar y concentrar la enzima, la actividad a $\mathrm{pH} 6.0$ se pudo detectar. 


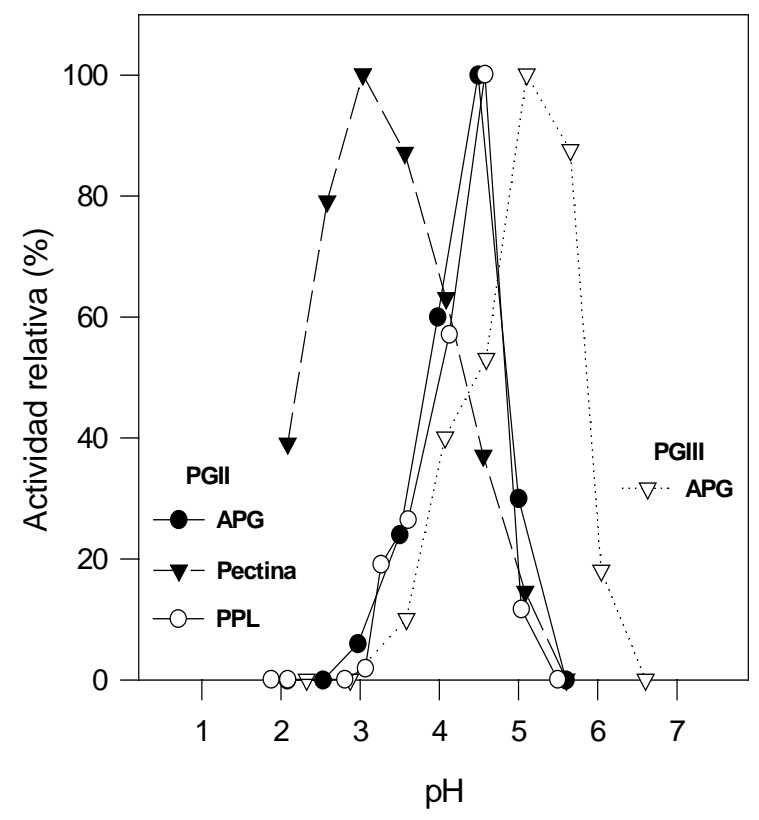

Figura 5.9. Efecto del pH en la actividad de PGII y PGIII.

La actividad sobre APG, pectina cítrica (GM 53) y protopectina se determinó en BCP según se describió en la sección 3. Los azúcares reductores se determinaron por el método del DNS. La concentración de proteína en la mezcla de reacción fue de $0.05-0.20 \mu \mathrm{g} / \mathrm{ml}$.

\subsubsection{Estabilidad térmica}

La estabilidad térmica de PGII fue evaluada incubando la proteína 30 min a $50{ }^{\circ} \mathrm{C}$ en BCP a diferentes $\mathrm{pH}$ en presencia de 100 ppm de albúmina. La máxima estabilidad se encontró a pH 3.5 con un $70 \%$ de actividad residual. En ausencia de albúmina, PG II fue muy poco estable. Comparativamente con PGI, esta PGasa posee una menor estabilidad térmica

\subsubsection{Especificidad de sustrato y acción endo/exo}

Las enzimas purificadas no mostraron actividad (2 horas de incubación en BCP, pH 5.0 y $37^{\circ} \mathrm{C}$ ) sobre los siguientes sustratos: arabinogalactano, carboximetilcelulosa, xilano y laminarina. Tampoco se detectó actividad transeliminativa frente a pectina altamente esterificada, confirmando de este modo la presencia exclusiva de la actividad hidrolítica. Ambas PGasas mostraron una mayor velocidad inicial de hidrólisis con APG comparada con pectina (GM 53), confirmando las preferencias de estas enzimas por las regiones no esterificadas o pobremente esterificadas de la pectina. Para determinar si el mecanismo de acción de PGII y PGIII es endo o exo, se determinó la relación entre la disminución de viscosidad de APG y el porcentaje de enlaces glicosídicos hidrolizados (en este caso estimado por el método de Somogyi-Nelson). Los resultados se muestran en la Figura 5.10. La acción 
enzimática fue la esperada para una acción de tipo endo, un 40 \% de caída de viscosidad para una hidrólisis reducida del sustrato, en este caso 1.2 \% para PGII y 2.2 \% para PGIII.

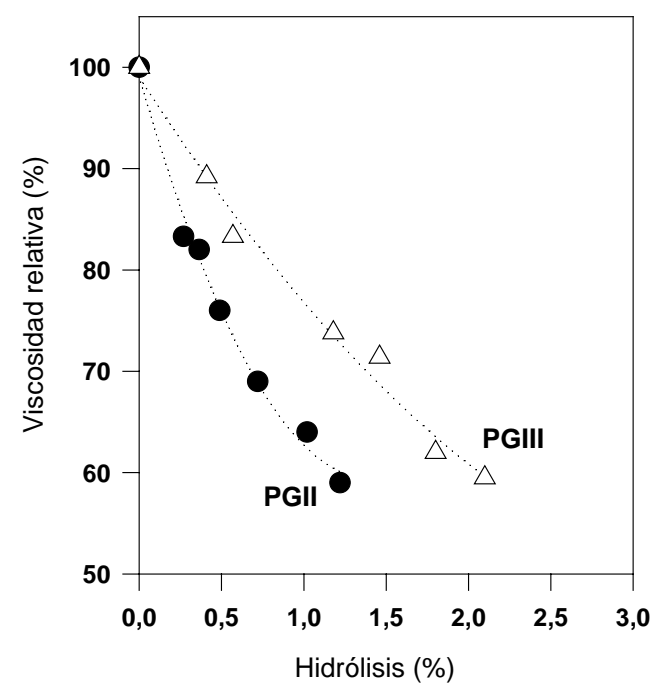

Figura 5.10. Cambios de viscosidad de APG en función del grado de hidrólisis para PG II y PG III.

Concentration de proteína en la mezcla de reacción 0.04-0.11 $\mu \mathrm{g} / \mathrm{ml}$. Porcentaje de hidrólisis determinado mediante el análisis de azúcares reductores con Somogyi-Nelson.

\subsection{Discusión}

La adsorción de las PGasas moderadamente ácidas de A. kawachii al FFV es un proceso altamente selectivo y reversible. El factor de purificación de las enzimas luego del proceso de adsorción/desorción fue $\sim 100$, siendo en este sentido la operación comparable con otros procesos de alta resolución, como la cromatografía de fase reversa, de afinidad o bioespecífica [Hearn and Anspach, 1990]. El análisis por SDS-PAGE del eluído del FFV y la cromatografía de intercambio catiónico mostró que las PGasas son prácticamente las únicas proteínas presentes luego del proceso de filtración (adsorción y elución), siendo consistente este resultado con los datos de proteína y actividad. La selectividad está íntimamente relacionada con las propiedades de las PGasas adsorbidas, pero también con las características de las proteínas contaminantes presentes en el medio glucosa, cuyo espectro es relativamente reducido. Cabría esperar una menor selectividad en la adsorción y por ende una menor purificación de las PGasas, si la separación se efectuara a partir de medios de cultivo con pectina o sustratos complejos (Capítulo 2), en los cuales se inducen una gran variedad de 
enzimas, algunas de las cuales, como la pectin-liasa, exhibieron también propiedades de adsorción a FFV.

Desde el punto de vista de la purificación de las PGasas, la filtración por FFV puede considerarse como un proceso integrativo, es decir permite separar fases (sólido/líquido), purificar y concentrar. Mas aún como operación unitaria contiene todas las ventajas del uso de membranas microporosas como proceso de bioseparación. Esta técnica emergente denominada cromatografía de membrana, posee varias ventajas respecto del uso de columnas como son: mayor caudal de operación debido a menores restricciones difusionales (alta relación area/volumen) y resistencia al flujo (menor caida de presión), mayor facilidad de cambio de escala y menor costo operativo [Thömmes.and Kula,, 1995; Ghosh, 2002]. Las membranas empleadas son de naturaleza microporosa y suelen ser modificadas para ser usadas como intercambiador iónico o bioespecífico. Debido a las características de flujo en la cromatografia de membrana, cuando se opera con altos caudales y se emplean medios con tamaño de poro grande $\sim 5 \mu \mathrm{m}$, pueden aparecer restricciones por transferencia de masa que limiten la adsorción. Esto es el alto flujo "arrastra" la biomolécula evitando su contacto o difusión hacia la fase sólid. En nuestro caso el FFV es un material fibroso con las características de un filtro de profundidad con un tamaño de poro de $1 \mu \mathrm{m}$ que se caracteriza precisamente por su velocidad de flujo rápido, capacidad de retención de partículas finas y alta capacidad de carga. Bajo las condiciones de filtración ensayadas se observó que la adsorción, que ocurre en todo el volumen del filtro, es prácticamente instantánea. No obstante la filtración se repitió tres veces reciclando el permeado para asegurar condiciones de equilibrio.

Con respecto a las proteínas purificadas, PGII puede considerarse como la PGasa moderadamente ácida representativa del medio glucosa/triptona, ya que representó mas del 95 \% de la actividad medida a pH 5.0. El análisis mediante IEF de la proteína pura no presentó la heterogeneidad típica de las poligalacturonasa fúngicas. En este sentido parece razonable asumir que $A$. kawachii en el medio glucosa no produce isoformas de las poligalacturonasas. PGII es una glicoproteína, a juzgar por su adsorción a ConA-Sepharose, su actividad es típica de una endo-poligalacturonasa y presentó un perfil de $\mathrm{pH}$ característico en APG y protopectina, que es consistente con lo esperado de los perfiles de $\mathrm{pH} /$ actividad observados con estos sustratos antes y después de la filtración del medio de cultivo por FFV (Capítulo 2). La actividad con pectina fue diferente; el máximo se corrió hacia la región más ácida, alrededor de 3.0, y presentó una significativa actividad a pH 2.0. Este comportamiento difiere de lo que ocurrió con PGI, en cuyo caso los sustratos esterificados, como pectina y 
protopectina, dieron máximos en la región más ácida en comparación con APG. Una explicación de este comportamiento no es obvia. Las propiedades de PGIII solo se determinaron en forma parcial. La enzima es una endo-PGasa y difiere de PGII en el perfil de pH con APG, siendo lo mas resaltable el hecho de que su actividad se extiende hasta pH 6.0.

Tal como se mencionara en el Capítulo 3, Kojima et al., [1999] reportaron la purificación de tres PGasas de la cepa IFO 4308 a partir de cultivos crecidos en un medio con harina de soja y peptona. El nivel de expresión de estas PGasas dependió del pH del medio. La PGasa B (PGase-B) representó el $70 \%$ de la actividad en cultivos con $\mathrm{pH}$ inicial 5.0. El perfil pH/actividad sobre APG de la PGasa-B coincide en parte con PGIII, pero ambas proteínas difieren en el peso molecular (71 kDa para PGase-B). Una diferencia mas remarcable aun es la propiedad de la PGasa-B de adsorberse a pH 5.0 a columnas de intercambio aniónico (DEAE Toyopearl 650 M o Mono Q), lo cual sugiere que la proteína tiene un pI < que 5.0. En cambio, a pH 5.0 PGII se adsorbe a matrices de intercambio catiónico (Sepharose SP), lo cual es consistente con el pI de la proteína ( 5.3). Es evidente que PGII y la PGasa-B son diferentes proteínas.

Las interacciones proteína/adsorbente se sustentan básicamente en cuatro tipos de uniones químicas (no covalentes): culómbicas o electrostáticas, enlaces de hidrógeno, puentes con iones metálicos y uniones de Van der Waals [Hearn and Anspach, 1990]. Para establecer las bases químicas de la adsorción es necesario conocer tanto las propiedades de superficie del adsorbente como las del adsorbato. Los resultados de adsorción observados con un soporte de vidrio borosilicato y el hecho que este material es el constitutente de las fibras del filtro, permite inferir que el borosilicato es el material adsorbente de las PGasas. El vidrio borosilicato contiene no menos de 13 \% de óxido de boro en su composición y un pequeño porcentaje de óxido de aluminio (Tabla 5.5 ).

Tabla 5.5. Composición del vidrio borosilicato

$\begin{array}{ccc}\mathrm{SiO}_{2} & ---- & 81 \% \\ \mathrm{Na}_{2} \mathrm{O} & ---- & 4.0 \% \\ \mathrm{~K}_{2} \mathrm{O} & ---- & 0.5 \\ \mathrm{~B}_{2} \mathrm{O}_{3} & ---- & 13.0 \% \\ \mathrm{Al}_{2} \mathrm{O}_{3} & ---- & 2.0 \%\end{array}$


Los grupos silanoles (Si-OH) son débilmente ácidos (el pI de la sílice se ha estimado en 2.0-3.0) pudiendo formar uniones iónicas o puentes de hidrógeno. Por su parte, la presencia de uniones de borosiloxano $(\equiv \mathrm{Si}-\mathrm{O}-\mathrm{B}=$ ) le confieren al vidrio borosilicato las propiedades características [Kyung et al, 1996]. La concentración de átomos de oxígeno libres (que no forman puentes) unidos al B tiene también un efecto importante en las propiedades del vidrio [Stebbins et al, 2000]. Los átomos de $\mathrm{B}$ (y Al) constituyen centros electrofílicos que pueden atraer a grupos donores como -OH y -NH [Grenn and Wase, 1986]. Por lo tanto en el vidrio borosilicato los grupos silanoles superficiales (disociados o no) como los átomos de $\mathrm{B}$ (y Al) y los oxígenos libres unidos a ellos constituyen potenciales sitios de interacción para las proteínas. Se ha observado que la máxima adsorción de proteínas, incluyendo poligalacturonasas, a materiales inorgánicos como arcillas (montmorollinita) y óxidos (sílice, alúmina o titanio) ocurre con frecuencia alrededor del pI de la proteína [Morgan and Corke, 1976; Green and Wase, 1986; Bailey and Ojamo, 1990; Quiquampoix et al., 1995]. Esta situación no se observó en la adsorción de las PGasas a FFV. Todas las PGasas muestran un perfil de adsorción en función del pH (para el rango estudiado) similar, independientemente del pI de la proteína. Mas aún, en algunos casos los pI de las proteínas difieren marcadamente e.j. 5.3 para PGII y 7.7 para la PGasa de G. klebanii. Además de las propiedades de las proteínas y del adsorbente, es necesario considerar la influencia del buffer en la adsorción. Algunos estudios preliminares con la PGasa de G. klebanii mostraron que el perfil pH/adsorción se modifica si el proceso se realiza en buffer acetato. En este caso la adsorción se observa incluso a pH 5.0. Sin considerar el "efecto buffer" y tomando en cuenta los pI de las PGasas, estas proteínas tienen una carga netamente positiva al pH de máxima adsorción, alrededor de 3.0. Esta situación sumada al hecho que la adsorción/desorción no es afectada por detergentes y muestre una marcada dependencia de la fuerza iónica y pH del medio, sugiere que la interacción principal de las PGasas con el vidrio borosilicato es de naturaleza electrostática y/o involucra puentes de hidrógeno. Este tipo de interacción es la que predomina en la adsorción de proteínas a materiales inorgánicos hidrofílicos como montmorollinita e incluso ha sido sugerida para explicar la adsorción de diferentes proteínas a membranas de vidrio porosas [Messing, 1969; Morgan and Corke, 1976, Quiquampoix et al, 1995]. Sin embargo, a diferencia de lo que ocurre con estos adsorbentes y con las matrices de intercambio iónico en general donde la unión del adsorbato es mas bien inespecífica, la adsorción de las PGasas a FFV presenta cierta bioespecificidad ya que PGI no se adsorbe a FFV a pH 2.0, no obstante tener en esta condición una carga netamente positiva (pI 3.7). Las PGasas fúngicas que se adsorben parecen compartir ciertas características estructurales 
comunes. Un hecho a destacar es que todas ellas son activas a $\mathrm{pH} 5.0$ pero inactivas a $\mathrm{pH} 2.0$ (APG como sustrato). En este sentido PGI parece ser la excepción en relación a la no adsorción a FFV.

Los estudios realizados demonstraron el potencial de los filtros de fibra de vidrio para la adsorción selectiva de algunas poligalacturonasas fúngicas. El empleo de la filtración como etapa de alta resolución de un proceso de purificación presenta las ventajas de ser simple, efectivo y de bajo costo. El diseño final del sistema dependerá de la escala de operación, costo, disponibilidad y performance del filtro [Fane and Radovich, 1990].

\subsection{Bibliografía}

Bailey, M.J. and Ojamo, H. (1990). Selective concentration of polygalacturonase and $\beta$-Dglucosidase of Aspergillus niger culture filtrate using mineral adsorbents. Bioseparation, 1:133-139.

Brocklebank, M.P. (1990). Downstream processing plant and equipment. In: Separation Processes in Biotechnology, Asenjo, J.A., Ed. Marcel Dekker, Inc: New York and Basel. pp, 617-740.

Fane, A. G. and Radovich, J. M. (1990). Membrane systems. In Separation Processes in Biotechnology, Asenjo, J.A., Ed.; Marcel Dekker: New York and Basel. pp, 209-262.

Gabler, F.R. (1985). Cell processing using tangencial flow filtration. In: Comprenhensive Biotechnology, Vol 2; M, Moo-Young., Ed; Pergamon Press: Oxford, New York, Toronto, Sydney, Frankfurt. pp, 350-366.

Ghosh, R. (2002). Protein separation using membrane chromatography: opportunities and challenges, Journal of Chromatography A (invited review article) 952: 13-27.

Green, S, and Wase, J. (1986). Practical and theoretical aspects of inorganic adsorbents technology in downstream processing. Process Biochemistry, 21:200-203.

Hearn, M. T. W. and Anspach, B. (1996). Chemical, physical and biochemical concepts in isolation and purification of proteins. In Separation Processes in Biotechnology, Asenjo, J.A., Ed. Marcel Dekker, Inc: New York and Basel, 1990, pp, 17-66.

Hlady, V. and Buijs, J. Protein adsorption on solid surfaces, a yearly review. Current Opinion in Biotechnology, 7:72 - 77.

Kojima, Y.; Sakamoto, T.; Kishida, M.; Sakai, T. And Kawasaki, H. (1999). Acidic condition-inducible polygalacturonase of Aspergillus kawachii. J. Mol. Catalysis B: Enzymatic, 6:351-357. 
Kyung, H.Y. and Ae, J.W. (1996). Solid-state ${ }^{1} \mathrm{H}$ and ${ }^{29} \mathrm{Si}$ NMR studies of silicate and borosilicate gel to glass conversion. Bulletin Korean Chemical Society, 17:696-699.

Messing, R.A. (1969). Molecular inclusions. Adsorption of macromolecules on porous glass membranes. Journal of American Chemical Society, 9:2370-2371.

Morgan, H.W. and Corke, C.T. (1976). Adsorption, desorption, and activity of glucose oxidase on selected clay species. Canadian Journal of Microbiology, 22:684-693.

Nicolau, V. D Jr.; Nicolau, V. D. (1999). A data base comprising biomolecular descriptors relevant to protein adsortion on microarray surfaces. http://www.swin.edu.au/iris/bcm/index.htm.

Quiquampoix, H.; Abadie J.; Baron, M.H.; Leprince, F.; Matumoto-Pintro, P.T.; Ratcliffe, R.G. and Staunton, S. (1995). Mechanisms and consequences of protein adsorption on soil mineral surfaces. In: Proteins at Interfaces; Horbett, T. H., Brash, J. L., (Eds.). ACS Symposium, Series 602, American Chemical Society. pp 321-333.

Sakai, T.; Sakamoto, T.; Hallaert, J.; and Vandamme, E. J. (1993). Pectin, pectinase and protopectinase: production, properties and applications. Advances Applied Microbiology. 39: 213-294.

Scott, C.W.; Gomes, B.C.; Hubbs, S.J. and Koenigbauer, H.C. (1995). A filtration-based assay to quantitative granulocyte-macrophage colony-stimulating factor binding. Analytical Biochemistry, 228:150-154.

Somogyi, M. (1952). Note on sugar determination. Journal Biological Chemistry, 195:19-23.

Thömmes, J., Kula, M.-R. (1995). Membrane chromatography - an integrative concept in downstream processing of proteins. Biotechnol. Progr. 11: 357-367.

Tovey, E. R. and Baldo, B.A. (1989). Protein binding to nitrocellulose, nylon and PVDF membranes in inmuno assays and electroblotting. Journal of Biochemical and Biophysical Methods. 19:169-183. 


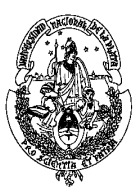

UNLP

Argentina

\section{$\mathbf{C}^{\text {aprTuLO }} 6$}

Tesis Doctoral

\section{Discusión general}

La búsqueda de enzimas pectolíticas con singulares propiedades físico-químicas motivó la realización de esta tesis, cuyo contenido se refiere específicamente al estudio de las pectinasas de Aspergillus kawachii, en particular las poligalacturonasas.

A. kawachii creció eficientemente en cultivos sumergidos utilizando fuentes de carbono simples como glucosa o complejas de origen vegetal como son la pomaza de limón, pulpa de tejocote, cáscara de mango o residuos de remolacha. Esto es debido a su capacidad para sintetizar una gran variedad de enzimas extracelulares que degradan los polisacáridos de la pared celular vegetal. Entre estas enzimas se encuentran las pectinasas. El screening de la actividad pectinolítica constituyó el primer estudio reportado sobre este sistema en A. kawachii. Como aporte original a la metodología de screening se desarrolló una técnica para la detección de enzimas que degradan ramnogalacturonano de soja, la cual se aplicó en ensayos de difusión en placa y electroforésis en SDS-PAGE. Los resultados del screening mostraron que el sistema pectinolítico de A. kawachii está constituido fundamentalmente por enzimas que degradan el esqueleto principal del homogalacturonano, como PGasas y PeL, enzimas accesorias como PME, arabinogalactanasas y varias glicosidasas, pero carece (o al menos no pudo detectarse por los métodos empleados) de una actividad enzimática que degrade ramnogalacturonano. Entre las actividades frente a glicósidos no previamente reportadas, merecen destacarse los altos niveles de alfa-arabinofuranosidasa y beta-galactosidasa.

La síntesis de PGasas resultó parcialmente constitutiva, en cambio PME, PeL y la mayoría de las glicosidasas se indujeron en medios con materiales vegetales complejos que contienen pectina. En este sentido la regulación de la síntesis de pectinasas en $A$. kawachii tiene características comunes a las descriptas en otros Aspergillus. Los cultivos con glucosa exhibieron también actividad solubilizadora de pectina de protopectina, pero esta actividad refleja en realidad la propiedad de las PGasas de degradar sustratos insolubles. 
Al menos tres PGasas fueron constitutivamente sintetizadas en el medio glucosa. Estas enzimas pueden separase en dos grupos según la propiedad de adsorberse a filtros de fibras de vidrio borosilicato. PGI puede considerarse como la PGasa ácida representativa del medio glucosa. PGI es una endo-PGasa que no se adsorbe al filtro y presenta como propiedad fundamental hidrolizar sustratos solubles e insolubles a $\mathrm{pH} \leq 3.0$. Esta propiedad diferencia PGI de la mayoría de las PGasas fúngicas. Algunas propiedades y la secuencia N-terminal de PGI coinciden con la reportada para la PPasa-AS de A. awamori, lo cual sugiere que ambas proteínas tienen un patrón genético común.

Los estudios de caracterización y degradación de diferentes protopectinas con PGI significan una contribución importante del presente trabajo al conocimiento de las reacciones heterogéneas con pectinasas. La susceptibilidad de las protopectinas a la degradación enzimática muestra cierta analogía con la degradabilidad química y parece relacionarse no tanto con la micro y macroestructura del sustrato o las propiedades cinéticas intrínsecas de la enzima, sino mas bien con las propiedades de solubilidad de las sustancias pécticas en función del pH y el grado de metoxilación. Las protopectinas con grado de metoxilación intermedio, entre 40 y 60 \%, resultaron ser las mas apropiadas para solubilizar pectina a $\mathrm{pH}$ 2.0.

A. kawachii fue seleccionado como candidato potencial para la búsqueda de PGasas ácidas con posible aplicaciones industriales. Por tal motivo PGI se empleó para la extracción de pectina de pomaza industrial de limón y la maceración de tejidos vegetales a pH 2.0. Circunstancialmente la pomaza industrial presentó un grado de metoxilación intermedio, factor que probablemente contribuyó a la eficiencia del proceso extractivo con la enzima. La pectina solubilizada en presencia de PGI resultó, respecto a la obtenida mediante tratamiento ácido a altas temperaturas, mas polidispersa con relación a la distribución de peso molecular, pero comparable en la distribución de carga. Esta última característica se puede atribuir a la baja actividad que presenta la pectin metil-esterasa endógena a $\mathrm{pH}$ 2.0, circunstancia que limita la desesterificación enzimática de la pectina durante la extracción. Esta situación fue evidente cuando se extrajo pectina a pH 4.5 con una PGasa de A. niger, que generó productos solubles de bajo grado de metoxilación. La determinación de la composición de azúcares de las diferentes fracciones que componen el extracto enzimático y de las propiedades de la pectina relacionadas con sus aplicaciones en alimentos no se realizó, debido a no disponer de PGI en cantidad suficiente para extraer pectina a una escala mayor. Sin embargo es probable que la pectina extraída con PGI 
tenga una composición química y presente propiedades de gelificación o emulsionantes similares a la pectina química. Esta situación debe ser elucidada en futuras investigaciones, las cuales deben necesariamente incluir la clonación y sobreproducción de PGI.

La PGasa ácida resultó muy eficiente para macerar tejidos vegetales lo que confirma su acción específica de hidrólisis sobre la laminilla media y pared celular primaria.

El otro grupo de PGasas producidas constitutivamente en el medio glucosa son aquellas que poseen la propiedad de adsorberse al filtro de fibra de vidrio. Estas PGasas no son activas a pH 2.0 pero lo son a $\mathrm{pH}$ 5.0, siendo en este sentido semejante a las clásicas PGasas del género Aspergillus. Al menos dos PGasas con esta característica fueron purificadas del medio glucosa. Una de ellas, PGII constituyó mas del 95 \% de la actividad PGasa total y por lo tanto es la PGasa no ácida representativa del medio glucosa.

Los estudios de adsorción/desorción de las PGasas con el filtro de fibra de vidrio representan otra contribución original de esta Tesis, en este caso al desarrollo de procesos de bioseparación. La filtración como operación unitaria y las propiedades de adsorción selectivas del filtro de fibra de vidrio permitieron desarrollar un procedimiento de aislamiento primario y purificación de las PGasas no ácidas con todas las ventajas de la cromatografía de membrana. Los estudios de adsorción/desorción sugieren que la interacción principal de las PGasas con el vidrio borosilicato es de naturaleza electrostática y/o involucra puentes de hidrógeno. La adsorción presenta además cierta bioespecificidad ya que PGI no se adsorbe al vidrio borosilicato.

En relación con la posible relevancia industrial y perspectivas futuras de las poligalacturonasas de A. kawachii, es de destacar el potencial de PGI como coadyuvante tecnológico en la extracción de pectina mediante tecnologías limpias, en la preparación de purés de vegetales y en todo proceso donde sea ventajoso trabajar a pH muy ácido sobre sustratos insolubles. Por otra parte y en lo que concierne a su actividad sobre sustratos solubles esta enzima puede ser de utilidad en la obtención de jugos y dulces a partir de frutos y flores ácidos como tamarindo, limón, lima ácida, acerola, sépalos de rosella. etc.

Desde el punto de vista básico, es interesante considerar el estudio de estas enzimas en el marco de la catálisis, para entender que factores determinan su estabilidad y acción a pH ácido, como también todo lo referente a los mecanismos regulatorios que actúan a nivel genético para modular la expresión de los genes que las codifican. 


\section{Divulgación de los resultados de la Tesis doctoral}

\section{Presentaciones a reuniones y Congresos Científicos}

4to Congreso Nacional de Biotecnología. Talca. Chile. 1998

Trabajo presentado: Enzimas solubilizadoras de pectina ácido-estables de Aspergillus kawachii J. C. Contreras Esquivel., R. A. Hours., C. F. Mignone, C. E. Voget.

4to Congreso Latinoamericano de Biotecnología y Bioingeniería. VIII Congreso Nacional de Biotecnología y Bioingeniería. Huatulco. México. 1999

Trabajo presentado: Caracterización preliminar de una enzima ácido-estable solubilizadora de pectina de Aspergillus kawachii J. C. Contreras Esquivel, R. A Hours, C. F. Mignone y C. E. Voget

BIOLATINA 2000. IV Feria Congreso Latinoamericano. II Congreso Argentino de Biotecnología. Buenos Aires. 2000

Trabajo presentado: Purificación y propiedades de una poligalacturonasa ácida de Aspergillus kawachii. J. C. Contreras Esquivel, C. E. Voget.

XXX Reunión Anual de SAIB. Villa Carlos Paz, Córdoba. 2001

Trabajo presentado: Pectolytic enzymes of Aspergillus kawachii. C, Vita, J. C. Contreras Esquivel, C. E. Voget.

$11^{\text {th }}$ World Congress of Food Science and Technology, Seul, Korea. 2001

Trabajo presentado: Detection of rhamnoglacturonan degrading enzymes in polyacrylamide gels. J.

C. Contreras Esquivel, C. E. Voget.

$12^{\text {th }}$ World Congress of Food Science and Technology, Chicago, USA, 2003

Trabajo aceptado: Pectin extraction with acidic polygalacturonase from Aspergillus kawachii

J. C. Contreras Esquivel, C. E. Voget, C.M.G. C. Renard

\section{Artículos publicados o en preparación}

Aspergillus kawachii produces an acid pectin releasing enzyme activity

J. C. Contreras Esquivel, R. A Hours, C. E. Voget and C. F. Mignone

Journal of Bioscience and Bioengineering. 88; 48-52, 1999.

Purification and characterization of an acidic polygalacturonase from Aspergillus kawachii. J. C. Contreras Esquivel, C. E. Voget.

Journal of Biotechnology. Aceptado

Selective adsorption of Aspergillus kawachii polygalacturonases onto glass fiber microfilters J. C. Contreras Esquivel, C. E. Vita, C. E. Voget

Biotechnology Progress. Enviado

A simple detection method for rhamnogalacturonan-degrading enzymes using ruthenium red. J.C. Contreras-Esquivel, C.E. Vita, and Claudio Enrique Voget.

Journal Microbiology and Biotechnology. En preparación. 